
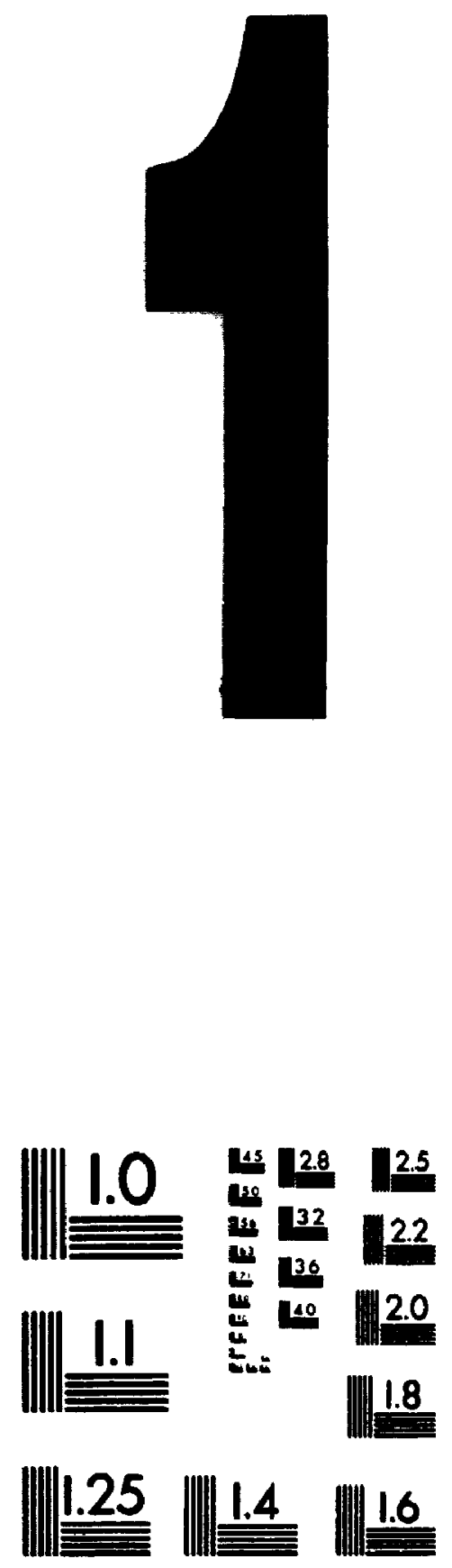

MICROCOPY RESOLUTION TEST CHART NATIONAL BUREAU OF STANDARDS STANDARD REFEAENCE MATERIAL 1010 (ANSI and ISO TEST CHART NO. 2) 


\section{Ottawa, Canada}

K1A ONA

\section{NOTICE}

The quality of this microlorm is heavily dependent upon the quality of the original thesis submitted for microtilming. Every effort has been made to ensure the highest quality of reproduction possible.

If pages are missing. contact the university which granted the degree.

Some pages may have indistinct print especially it the original pages were typed with a poor typewriter ribbon or if the universily sent us an interior photocopy.

Reproduction in full or in part of this microform is governed by the Canadian Copyright ACt. R.S.C. 1970, C. C-30, and subsequent amendmenis.

\section{AVIS}

La qualité de celte microforme dépend grandement de la qualité de la thèse soumise au microfilmage. Nous avons tout fait pour assurer une qualité supérieure de reproduc tion.

S'il manque des pages, veuillez communiquer avec juniversité qui a conféré le grade.

La qualité d'impression de certaines pages peut laisser à désirer, surtout si les pages originales ont élé dactylogia phiées a l'aide d'un ruban usé ou si l'université nous a fall parvenir une photocopie de qualite interieure.

La reproduction, méme partielle, de celle microforme est soumise a la Loi canadienne sur le droit d'auteur, SRC 1970, c. C-30, et ses amendements subséquenis. 


\title{
Volcanic and Sedimentary Rocks of the Yellowknife Bay Formation, Giant Section, Yellowknife Greenstone Belt, NWT.
}

\author{
HENDRIK FALCK, B.Sc.
}

\author{
A thesis submitted to \\ the Faculty of Graduate Studies and Research, \\ in partial fulfilment of \\ the requirements for the degree of \\ Master of Science
}

Department of Earth Sciences,

Carleton University

Uttawa-Carleton Geoscience Centre

Ottawa, Ontario

July 10, 1990

- Copyright

1990, Hendrik Falck 
Otawa, Canada

Kia ONe

\section{NOTICE}

The quality of this microlorm is heavily dependent upon the quality of the original thesis submitted for microlitming. Every effor has been made to ensure the highest quality of reproduction possible.

It pages are missing. contact the university which granted the degree.

Some pages may have indistinct print especially if the original pages were typed with a poor typewriter ribbon or if the university sent us an inferior photocopy.

Reproduction in full or in part of this microtorm is governed by the Canadian Copyright ACt, R.S.C. 1970. C.C-30. and subsequent amendments.

\section{AVIS}

La qualité de cette microlorme dépend grandement de la qualité de la thése soumise au microfilmage. Nous avons tout lait pour assurer une qualité supérieure de reproduction.

S'il manque des pages, veuillez comrruniquer avec Puniversité qui a conféré le grade.

La qualite dimpression de centaines pages peut laisser à désirer. surtout si les pages originales ont été dactylogra. phiées à raide duun nuban usé ou si luniversité nous a tail parvenir une photocopie de qualité ințérieure.

La reproduction, méme partielle. de cefte microtorme est soumise a la Loi canadienne sur le drofi d'auteur. SRC 1970. c. C-30, et ses amendements subséquents.

ISBN $\quad 0-315-60491-3$ 
The undersigned hereby recommend to the Faculty of Graduate Studies and Research acceptance of the thesis,

Volcanic and Sedimentary Rocks of the Yellowknife Bay Formation, Giant Section, Yellowknife Greenstone Belt, NWT.

\author{
Submitted by \\ Hendrik Falck, B.Sc.
}

in partial fulfilment of

the requirements for the degree of

Master of Science

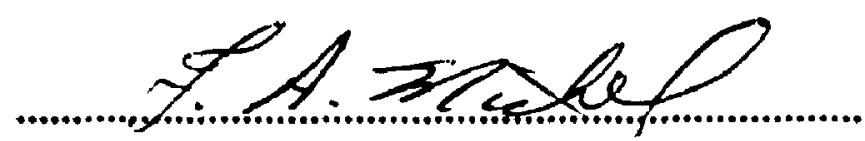

Chairman, Department of Earth Sciences

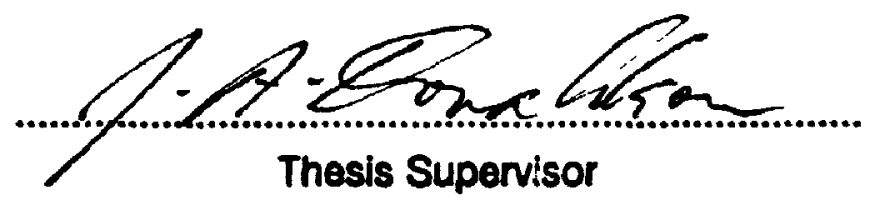

Department of Earth Sciences,

Carleton University 


\section{ABSTRACT}

Excellent exposure in the "Giant Section". five kilometres north of Yellowknife, NWT., allows detailed study of a homoclinal succession of Archean mafic and felsic volcanic, volcaniclastic, and intrusive rocks and intercalated sediments of the Yellowknife Bay Formation, Upper Kam Group. The Bode member, a mafic heterolithic tuff containing rhyodacite boulders, marks a change from quiet extrusion of massive and pillowed basalt to explosive volcanic activity. a characteristic of the overlying Banting Group.

Six clastic dykes occur within a pilluwed lava flow above the Bode Member. These dykes are infilled by lithic sandstone that merges with an overlying bed of sandstone. The dyke margins cut across some of the pillows, but for the most part conform to pillow selvages, suggesting that the fractures formed soon after consolidation of the flow. The fracturing is attributed to intrusion of a shallow-level sill that inflated an underlying flow not yet completely solidified. 
Excellent exposure in the "Giant Section", five kilometres north of Yellowknife, NWT., allows detalled study of a homoclinal succession of Archean mafic and felsic volcanic, volcaniclastic, and intrusive rocks and intercalated sediments of the Yellowknife Bay Formation, Upper Kam Group.

The Bode member, a mafic heterolithic tuff containing inyodacite boulders, marks a change from quiet extrusion of massive and pillowed basalt flow to explosive volcanic activity, a characteristic of the overtying Banting Group. Uplift between Yellorex extrusion and Bode deposition produced shallow-water conditions and the slopes required for explosive vesiculation and flow movement. Lahars lesued from a volcanic vent, proximal to the Giant Section, and flowed from northeast to southwest. Remobilized as debris flows, the pyroclastic detritus was deposited in proximal coarse-tall graded deposits and finer normally graded distal beds to the south.

The use of the Bode member for radiometric dating to test stratigraphic models should be approached with caution. In the Bode member, the only zircon sources are rhyodacite clasts which were probably torn from the Townsite Formation. Consequently the zircon ages reflect the crystallization of this older felsic formation, not deposition of the Bode member.

The Bode member is overlain by a transitional sequence from mafic to felsic volcanism. This contrasts with an angular unconformity in northern parts of the volcanic belt. Concurrence of sedimentation, gabbro intrusion, and flow extrusion suggests the need for reassessment of the stratigraphy of the Giant Section, specifically the nature of the Kam Group-Banting Group boundary. Multiple dykes that feed pillowed flows and gabbroic sills in the Kam Group can be traced into the Banting Group, where they appear to also feed both gabbro sills and massive flows. Felsic volcanism is first marked by quartz-rich sandstone beds in the Bode member. Interbeds of sandstone rich in felsic fragments provide additional evidence of increasing felsic volcanism higher in the succession, and the progression is capped by felsic ash beds and ignimbrites interbedded with mafic flows.

Closely spaced sampling in the Giant Section demonstrates that where the field relationships are well defined, the chemistry of the rocks is for the most part predictable, and may be used for small-scale mapping. Alteration and metamorphism have not obliterated geochemical patterns, and the influences of hydrothermal alteration cells can be defined.

Clastic dykes, all within a non-variolitic pillowed lava flow, are unique features of the Giant Section. These six dykes are infilled by well-sorted lithic sandstone that merges with an overlying bed of sandstone. Laminations parallel to local bedding indicate that the dykes were formed by passive infilling of fractures. The dyke margins cut across some of the pillows, but for the most part conform to pillow selvages,suggesting that the fractures formed soon after consolidation of the flow. The fracturing is attributed to intrusion of a shallow-level sill that inflated an underlying flow not yet completely solidified. Although this model is complex, it fits the available evidence, and it explains all of the features associated with the dykes. This model may have implications that are not restricted to the small area in the Giant Section from which it is derived. 
This investigation has had financial support from Carleton University, Indian and Northern Affairs Canada (INAC), including two Northern Science Training Grants (to H.F.), and NSERC (Grant A5536 to J.A.Donaldson). Additional assistance and research support was provided by the Geology Division of INAC, Yellowknife, as well as the Geological Survey of Canada. Special thanks are due to J.A. Donaldson, for direction, guidance, and letting me make enough mistakes to learn from, W.A. Padgham, who encouraged and supported this study and $C$. Jefferson, who arranged for the chemical analyses. Important contributions were made by all the people who took the time to visit the Giant Section with me including G. Potts, W. Fyson, S. Roscoe, V. Jackson, J. Franklin, C. Isachsen and D. Atkinson. Giant Yellowknife Mines, represented by F. Perrino and B. Timler, and Nerco-Con Mines, represented by T. Bachelor and R. Hauser, are thanked for access to their properties. Thanks as well to P. Mustard, J. Richardson, and D. Thorkelson and especially B. Sedgwick and D. Cloutier, whose inputs may not have been directly to the study, but were nonetheless important in its completion. 
Acceptance Sheet $\ldots \ldots \ldots \ldots \ldots \ldots \ldots \ldots \ldots \ldots \ldots \ldots \ldots \ldots$ it

Abstract $\ldots \ldots \ldots \ldots \ldots \ldots \ldots \ldots \ldots \ldots \ldots \ldots \ldots \ldots \ldots$ iit

Acknowledgements $\ldots \ldots \ldots \ldots \ldots \ldots \ldots \ldots \ldots \ldots \ldots$ iv

Table of Contents $\ldots \ldots \ldots \ldots \ldots \ldots \ldots \ldots \ldots \ldots \ldots \ldots \ldots \ldots \ldots$ v

List of Figures $\ldots \ldots \ldots \ldots \ldots \ldots \ldots \ldots \ldots \ldots \ldots \ldots \ldots \ldots$ vii

List of Plates $\ldots \ldots \ldots \ldots \ldots \ldots \ldots \ldots \ldots \ldots \ldots \ldots \ldots \ldots$ ix

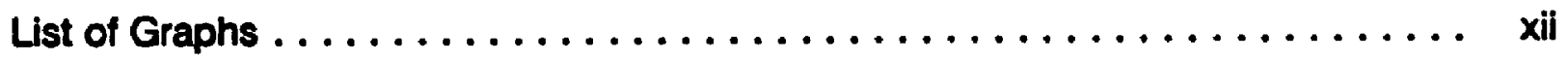

Introduction and Previous Work $\ldots \ldots \ldots \ldots \ldots \ldots \ldots \ldots \ldots \ldots$

Introduction to Yellowknifs Geology $\ldots \ldots \ldots \ldots \ldots \ldots \ldots \ldots \ldots \ldots \ldots$

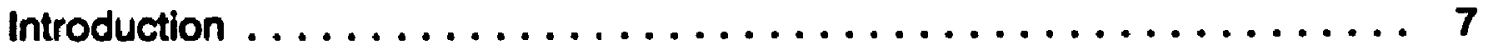

Stratigraphy $\ldots \ldots \ldots \ldots \ldots \ldots \ldots \ldots \ldots \ldots \ldots \ldots \ldots \ldots \ldots \ldots \ldots{ }^{12}$

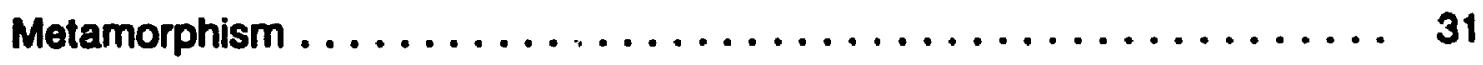

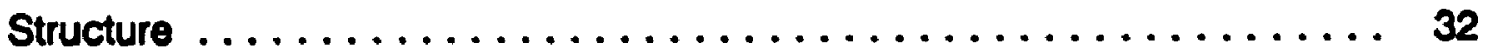

Introduction to the Giant Ser $: \ldots n \ldots \ldots \ldots \ldots \ldots \ldots \ldots \ldots \ldots$

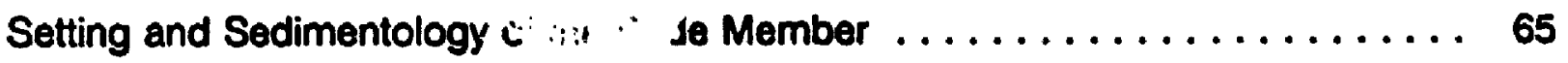

Introduction ............................. 66

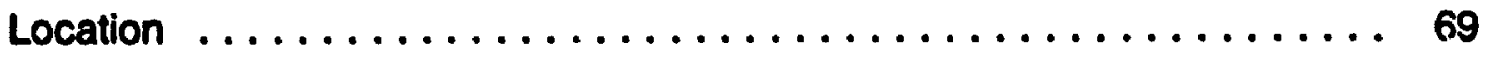

Setting $\ldots \ldots \ldots \ldots \ldots \ldots \ldots \ldots \ldots \ldots \ldots \ldots \ldots \ldots, 72$

Sedimentary Characteristics of the Bode Member $\ldots \ldots \ldots \ldots \ldots \ldots 73$

Clasts .............................. 73

Proximal Deposits ..................... 75

Distal Deposits $\ldots \ldots \ldots \ldots \ldots \ldots \ldots \ldots \ldots \ldots \ldots \ldots \ldots, 88$ 
Discuselon $\ldots \ldots \ldots \ldots \ldots \ldots \ldots \ldots \ldots \ldots \ldots \ldots \ldots \ldots \ldots$ g4

Bode Member facles $\ldots \ldots \ldots \ldots \ldots \ldots \ldots \ldots \ldots \ldots \ldots \ldots \ldots, \quad 97$

Clast $\ldots \ldots \ldots \ldots \ldots \ldots \ldots \ldots \ldots \ldots \ldots \ldots \ldots$ 88

Proximal Facter $\ldots \ldots \ldots \ldots \ldots \ldots \ldots \ldots \ldots \ldots, 100$

Distal Depoest ...................... 103

Dopositional History $\ldots \ldots \ldots \ldots \ldots \ldots \ldots \ldots \ldots \ldots \ldots \ldots \ldots \ldots, 108$

Conclusions $\ldots \ldots \ldots \ldots \ldots \ldots \ldots \ldots \ldots \ldots \ldots \ldots \ldots \ldots \ldots \ldots$

The Nature of the Kam Group - Banting Group Contact . . . . . . . . . . 112

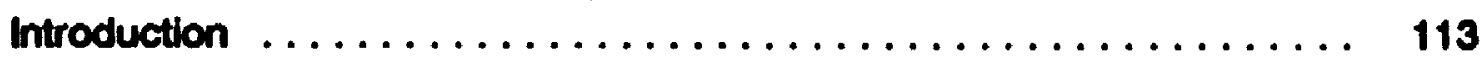

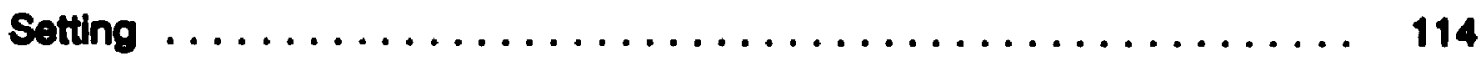

Field Rolationships $\ldots \ldots \ldots \ldots \ldots \ldots \ldots \ldots \ldots \ldots \ldots \ldots \ldots \ldots, 117$

Chemistry . . . . . . . . . . . . . . .

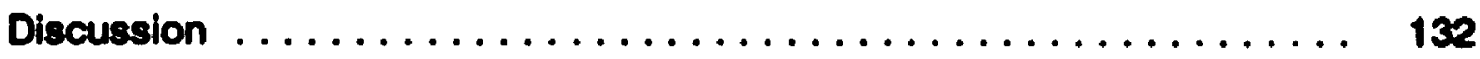

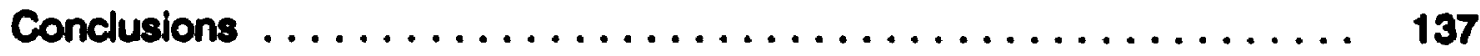

The Origin of Clastic Dykes . . . . . . . . . . . . . . . . . . . . . 139

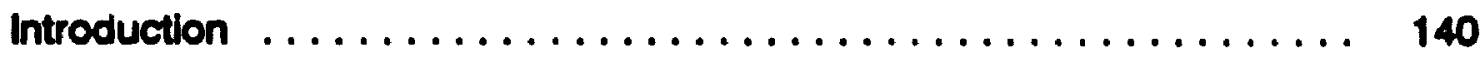

Dyke Character . ............................. 143

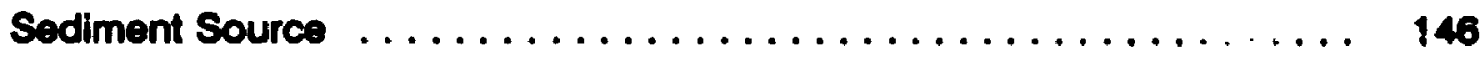

Timing of Formation $\ldots \ldots \ldots \ldots \ldots \ldots \ldots \ldots \ldots \ldots \ldots \ldots \ldots \ldots \ldots$

Dyke Formation Model $\ldots \ldots \ldots \ldots \ldots \ldots \ldots \ldots \ldots \ldots \ldots \ldots \ldots, 159$

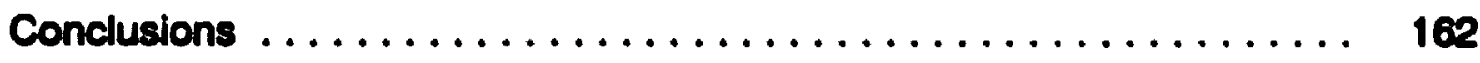

References $\ldots \ldots \ldots \ldots \ldots \ldots \ldots \ldots \ldots \ldots \ldots \ldots \ldots \ldots \ldots \ldots, 163$

Appendix $1 \ldots \ldots \ldots \ldots \ldots \ldots \ldots \ldots \ldots \ldots \ldots \ldots \ldots \ldots \ldots \ldots \ldots \ldots$ 
List of Figures

Figure 1. General Geology of the Slave Province.

Figure 2. General Geology of the Yellowknife Basin.

Figure 3. Comparison of past stratigraphic subdivisions of supracrustal rocks near the Yellowknife Area.

Figure 4. Stratigraphy of the Yellowknife Supergroup.

Figure 5. General Geology of the Yellowknife area.

Figure 6. Kan Group samples plotted on a Jonson's Cation diagram.

Figure 7. Metamorphic isograds in the Yellowknife Supergroup metasediments.

Figure 8. Simplified Geology of the Yellowknife Region showing the location of the Giant Section.

Figure 9. Geology of the Giant Section.

Figure 10. Simplified Geology of the Yellowknife Region showing sedimentary interbeds and location of the Giant Section.

Figure 11. Location of the Bode member.

Figure 12. Idealized sections through the Bode member.

Figure 13. Sections across the Bode member.

Figure 14. Model for deposition of the Bode member.

Figure 15. Depositional model for the Kan Group - Banting Group Contact.
3

8

10

13

16

25

33

40

42

67

70

80

82

109

135

vii 
Figure 16. A reconstructed cross-section of the clastic-dyke zone using a sandatone bed as a baseline.

Figure 17. Map of a sandstone dyke.

Figure 18. Map of a sandstone dyke.

Figure 19. Contact between the upper sandstone and the pillowed flow showing continuity of sandstone in the dyke and the overlying bed.

Figure 20. Model of Dyke formation. 160

Appendix I Figure. Location map of Geochemical Samples. 
Plate 1.

1a. The Yellorex Member in steep ridges at the Giant Section.

1b. Hyaloclastte and quartz pods infilling the interstices between variolitic pillows of the Yellorex Member.

1c. Typical plllows of the upper flow in the Yellorex Members.

1d. Rounded inyodacite boulders in the Bode member.

Plate 2.

2a. Budding of pillow of the *5 fow.

2b. Repeated vesiculated drainage shelves.

2c. Aerial view of $* 5$ Flow.

Plate 3.

3a. Pillow breccia fragments in \#5 flow.

3b. Coarse mottled texture in the core of larger sills and dykes.

3c. Multiple graded zones in the core of several large sills.

3d. Flow-top breccia overlying the flow-sill complex.

Plate 4.

4a. Pillows resting on the cross-bedded lower sandstone.

4b. Fine-grained chilled sill (Top) in contact with cross-bedded sandstone.

4c. Aerlal view of a large mafic dyke.

4d. Banting Group massive ash flow grades into laminated chert beds.

Plate 5.

5a. Ignimbritic welded ash in the Banting Group.

5b. Felsic dyke cutting through the Yellorex Member.

5c. Selvage-like features in the walls of a small dyke.

5d. Perlitic fractures in a piiow.

Plate 6.

6a. Jackson Lake Formation conglomerate.

6b. Aerial view of contacts between the Kam Group, the Banting Group and the Jackson Lake Formation. 


\section{List of Plates}

Plate 7.

7a. Dark brown sulphide-rich clasts.

7b. A large angular mafic clast displaying varioles.

7c. Examples of large well-rounded ithyodacte boulders.

7d. Fragmental Rhyodactte clast.

Plate 8.

8a. Example of a sedimentary clast with vague, gradational boundaries.

8b. Pillowe resting on cross-bedded sandstone.

8c. Angular fragment of laminated sandstone.

8d. Dark lensoidal clasts with wispy terminations.

Plate 9.

9a. Erosional contact between the Bode member and the Yellorex Member.

9b. Topography of the Bode basal contact is controlled by pillows.

Plate 10.

10a. Coarse-tail grading in the Bode member.

10b. Hyaloclastite-rich sediment showing parallel stratification.

10c. Rippled sandstone capping a graded sequence.

Plate 11.

11a. Rusty sulphide-rich bed which has been preserved.

11b. A typical example of distal graded beds.

11c. Large channel at Section Eleven (marked by white tape).

Plate 12.

12a. Pillow flow overlying cross-bedded sand.

12b. Sandstone dyke between two pillow selvages.

Plate 13.

13a. Photomicrograph of sandstone dyke/pillow selvage contact.

13b. Photomicrograph of sendstone dyke/fractured pillow contact.

13c. Sandstone dyke that has filled a fracture through the core of a pillow. 
List of Plates

Plate 14.

14a. Photomicrograph of lower sandstone.

14b. Photomicrograph of upper sandstone.

14c. Photomicrograph of sandstone dyke.

140. Dyke sandstone displaying coarse angular fragments.

152

Plate 15.

15a. Sandstone dyke containing sightly displaced pillow fragments.

15b. Lamination s in a sandstone dyke.

15c. Contact between the upper sandstone and the pillowed flow.

154

$\boldsymbol{x j}$ 
List of Graphs

Graph 1.

AFM Diagram for the Yellorex Flows, *5 Flows and overlying basalt.

96

Graph 2.

$\mathrm{CaO}-\mathrm{Na}_{2} \mathrm{O}-\mathrm{K}_{2} \mathrm{O}$ Diagram for the Yellorex Flows, $* 5$ Flows and overlying basalt.

96

Graph 3.

MORB normalized Diagram for the Yellorex Flows, *5 Flows and overlying basalt.

96

Graph 4.

Alkali - FoO- MoO Diagram for the *5 Flows, Kan Sills and Kan Dykes.

122

Graph 5.

$\mathrm{SIO}_{2}(\%)$ vs. FeO/MgO (\%) Diagram for the *5 Flows, Kan Sills and Kan Dykes. 122

Graph 6.

Ti (ppm) vs. V (ppm) Diagram for the *5 Flows, Kan Sills and Kan Dykes.

122

Graph 7.

Log Ti (ppm) vs. Log Zr (ppm) Diagram for the *5 Flows, Kan Sills and Kan Dykes.

123

Graph 8.

MORB-Normalized Diagram for the *5 Flows, Kan Sills and Kan Dykes.

123

Graph 9.

Alkali - F60" - Mg Diagram for Mafic Volcanic and Intrusive Rocks.

125

Graph 10.

$\mathrm{SiO}_{2}(\%)$ vs. FeO/MgO (\%) Diagram for Manic Volcanic and Intrusive Rocks.

125

Graph 11.

T1O (ppm) vs. V (ppm) Diagram for Manic Volcanic and Intrusive Rocks.

127

xii 


\section{Graph 12.}

$\log \mathrm{TI}(\mathrm{ppm})$ vs. Log Zr (ppm) Diagram for Mafic Volcanic and Intrusive Rocks.

\section{Graph 13.}

MORB Normalized Dlagram for Yellorex Flows, *5 Flows, Epidote Pod and Upper Pillow Flows.

Graph 14.

MORB Normalized Diagram for Banting Sill, Kam Sill and *5 Flows.

Graph 15.

MORB Normalized Diagram for Late Dyke, Kam Dyke and \#5 Flows.

Graph 16.

Alkali - FeO' - MgO Diagram for Banting Group and Jackson Lake Formation.

Graph 17.

$\mathrm{SiO}_{2}(\%)$ vs. FeO/MgO (\%) Diagram for Banting Group and Jackson Lake

Formation.

Graph 18.

TI (ppm) vs. V (ppm) Dlagram for Banting Group and Jackson Lake Formation.

Graph 19.

Log $\mathrm{TI}(\mathrm{ppm})$ vs. Log Zr (ppm) Diagram for Banting Group and Jackson Lake Formation.

Graph 20.

Morb Normalized Diagram for Banting and Kam Group Felsic Rocks.

Giaph 21.

MORB Normalized Diagram for Jackson Lake Formation. 


\section{Introduction and Previous Work}


The study of Archean terranes is eerlously hindered by the scarcity of good exposures. Where rock has been preserved since the Archean, it is often highly metamorphosed, deformed, or poorly expoeed. Fow areas exist where Archean rocks can be examined on a variety of scales, from the miero- to the macroscopic scale. The consequence of the paucity of data has been hypotheses and theories suggesting that the mechanisms controlling rock formation in the Archean were different from those active today. The Giant Section in the Yellowknife volcanic belt is an exceptional area which allows the detailed examination of relatively undeformed and silghtly metamorphosed Archean rocks on a variety of scales.

This thesis is presented as a series of chapters examining different aspects of the Giant Section. It begins with an overviow of the geology of the Yellowknife region. The Giant Section is introduced in the second part, which may also be used as a field guide. Chapter Three examines the setting and sedimentology of the Bode Member and Chapter Four is a discussion about the nature of the Kam Group - Banting Group Contact based on the field relationships and geochemical sampling in the Giant Section. The final chapter examines an unusual series of clastic dykes exposed in the Giant section and Offers a model for their formation.

The Yellowknife volcanic belt is a structurally complex domain preserving an intricate geological history of mafic and folsic volcanism and intrusion, terrestrial and marine sedimentation, granite emplacement, contact and regional metamorphism, and transcurrent faulting. It is the best known and most thoroughly researched volcanic belt in the Slave Province (Figure 1). An abundance of gold in the belt has prompted much of this intensive study. By the end of 1988, Yellowknife mines had produced 403 tonnes $(13,000,000$ ounces), largely from ore bodies hosted in a set of anastomosing shear zones in the Yellowknife Bay Formation.

Athough early explorers such as Hearne, Franklin, and Back travelled through the Yellowknife area, Stockwell (1932) wrote the first geological evaluation. Detailed mapping and analysis of the economic potential of the area was initiated by A.W. Jollifie of the Geological Survey of Canada (GSC) in 1935, after the discovery of gold in turbidite-hosted quartz veins on the eastern side of Yellowknife Bay. By the end of 1935, prospectors and 
Figure 1. 


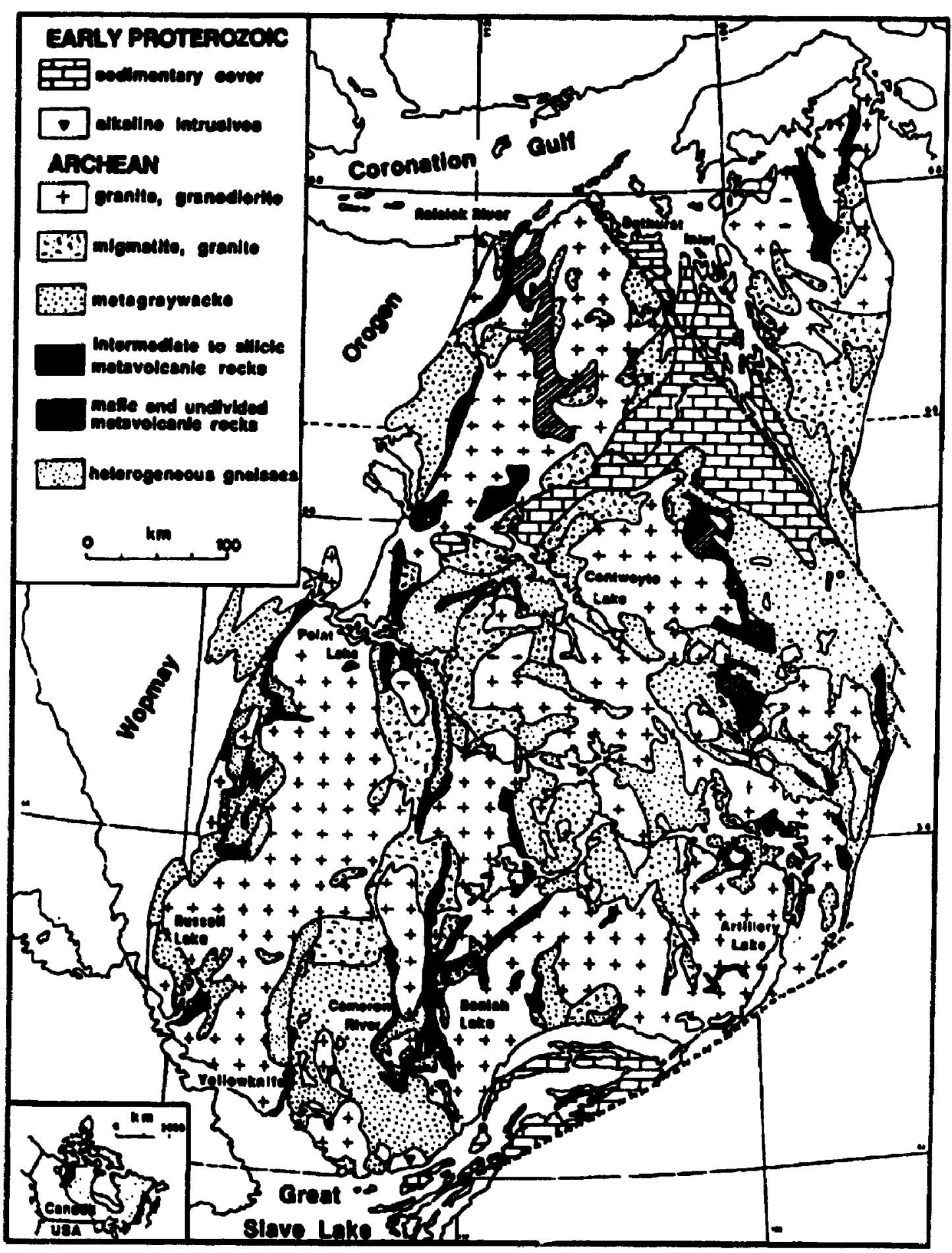


geologists of the Consolidated Mining and Smelting Company (later Cominco) had staked numerous claims that became the Con Mine Property, In 1938, underground development and mill construction started, and the first gold brick was poured. At the Giant Mine, $10 \mathrm{~km}$ north of the Con Mine, the first gold brick was poured in 1948.

Additional systematic geological mapping was undertaken through the GSC, and a compilation map of the Beaulieu River area was published in 1938 (Henderson, 1930). Investigative efforts were concentrated on the gold-bearing volcanic rocks (o.g., Henderson \& Brown, 1966: Jolliffe, 1936; 1948; Baragar, 1966; Boyle, 1961). The rocks of the Yeilowknife area were designated as part of the "Yellowknife Group" by Henderson (1938), and a type section for the Yellowknife Group was designated in the Beaulieu Piver area. Henderson and Brown (1966) produced a detailed map of the central portion of the volcanic belt. J.B. Henderson (1970) raised the Yellowknife Group to "Yellowknife Supergroup" status to describe all supracrustal successions in the Slave Province.

A research project was started in 1975 by the NWT Geology Division of the Northern Affairs Program. Under the direction of W.A. Padgham, 1:10,000 scale maps of supracrustal geology in NTS map areas $85 \mathrm{~J} / 7,8,9$ and $85 \mathrm{~J} / 16$ were produced, delineating the Banting Group, the Duck Lake Formation, the Clan Lake Felsic Complex, and the northern extension of the Yellowknife belt in the Quyta Lake area. A regional map of the Yellowknife-Hearne Lake area by J.B. Henderson was published in 1985. The stratigraphy of the volcanic belt that J.B. Henderson presised was redefined by Helmstaedt and Padgham (1986a), allowing more significant subdivision of the volcanic pile into easily mapped units. This stratigraphic re-interpretation, based on mapping in the Walsh Lake area, prompted re-examination of gold-bearing shear zones leading to better definition of the major structural features (Fyson, 1982). The lower volcanic units were compared to ophiolite sequences by Helmstaedt et al. (1986).

A comprehensive field gulde to the Yellowknife belt and surrounding region has recently been published for the Geological Association of Canada Summer Field Meeting (Padgham, 1987a). The structure of the Slave Province and the position of the Yellowknife domain has been the toplc of soveral recent papers including Fyson and Helmstaedt (1988) and Kushy (1989). 
Introduction to the

\section{Yellowknife Volcanic Belt}


Introduction

The Yellowknife volcanic belt is near the southwestern margin of the Slave Structural Province, one of the ten structural provinces in the Canadian Shield. The belt lies along the western border of a greywacke-filled sedimentary basin, called the Yellowknife Basin (Figure 2). The basin li up to $120 \mathrm{~km}$ wide and at least $180 \mathrm{~km}$ long, with its southern limit concealed beneath Great Slave Lake.

Yellowknite Supergroup stratigraphy has undergone several stages of revision in Its evolution (Figure 3). Jollifie (1936; 1946) distinguished Division A at the base, consisting mainly of mafic flows, followed by Division B, of conglomerates, arkosic quartzites, and intermediate to felsic volcanic rocks, and Division C, of greywacke and slate. J.F. Henderson and Brown (1966) retained these major subdivisions but suggested that the conglomerates thought by Jollifie to be at the base of Division $B$ may be significantly younger than the rest of the Yellowknlie Supergroup.

The Yellowknife Supergroup established by J.B. Henderson (1970) was based on a type locality in the Beaulieu River area, but it has been used to describe any supracrustal sequence in the Slave Province. As a cautionary note it should be stated that, with the exception of greywacke and other turbidite deposits, the units at the type section and Yellowknife are very localized. Reliable correlation of units in the Yellowknife area to other volcanic belts is impossible and the nomenclature for the Kam Group should not be used to describe similar mafic units in other belts (Henderson, 1985).

According to Hendersons's (1970) nomenclature, the Beaulieu Group replaces the Division $A$ but, the iraftition of distinguishing the mafic volcanics at the base of the Yellowknife Supergroup as a separate dlvision was continued. In the Beaulieu Group are the predominantly mafic Kam Formation on the west side of Yellowknife Bay, and the mafic to intermedlate Duck Formation on the east side (Figure 3). The Duncan Lake Group includes most of the turbidite sedimentary units of previous stratigraphic schemes, but with a fow changes. Conglomerates and sandstones of the Jackson Lake Formation 
Introduction to Yellowknife Geology

8

Figure 2. 


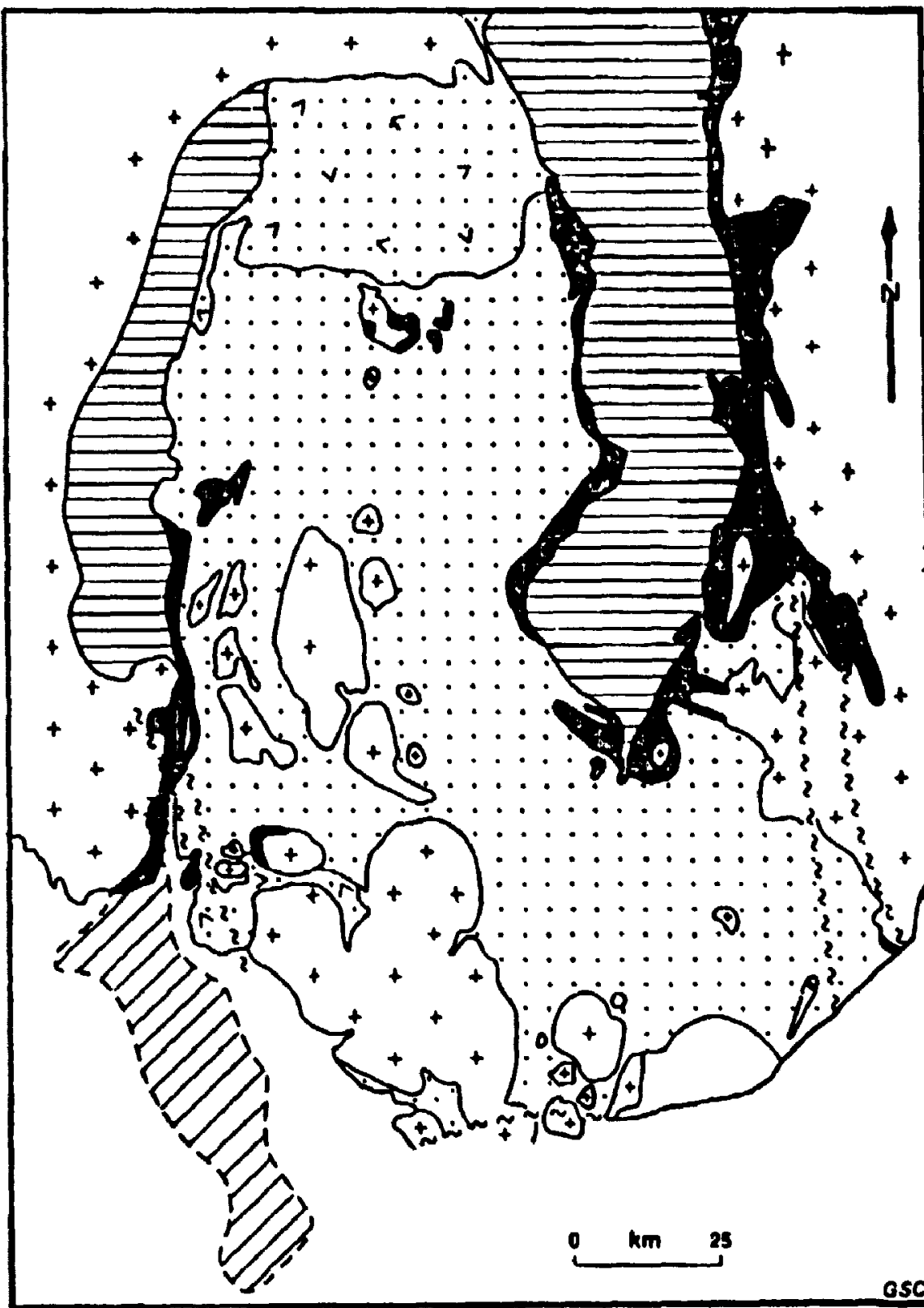

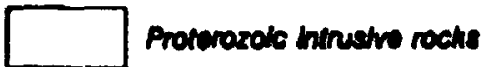

$+\ldots$ Arctane inirusion rocks

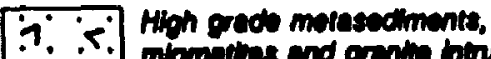

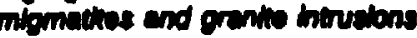

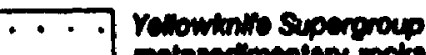

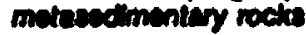

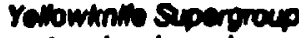
molavelente nock

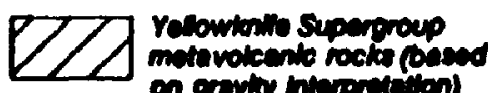

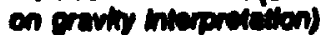

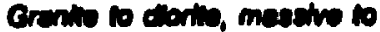

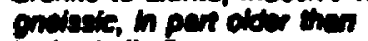

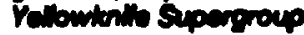

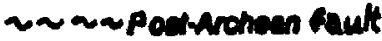


Introduction to Yellowknife Geology

10

Figure 3. 


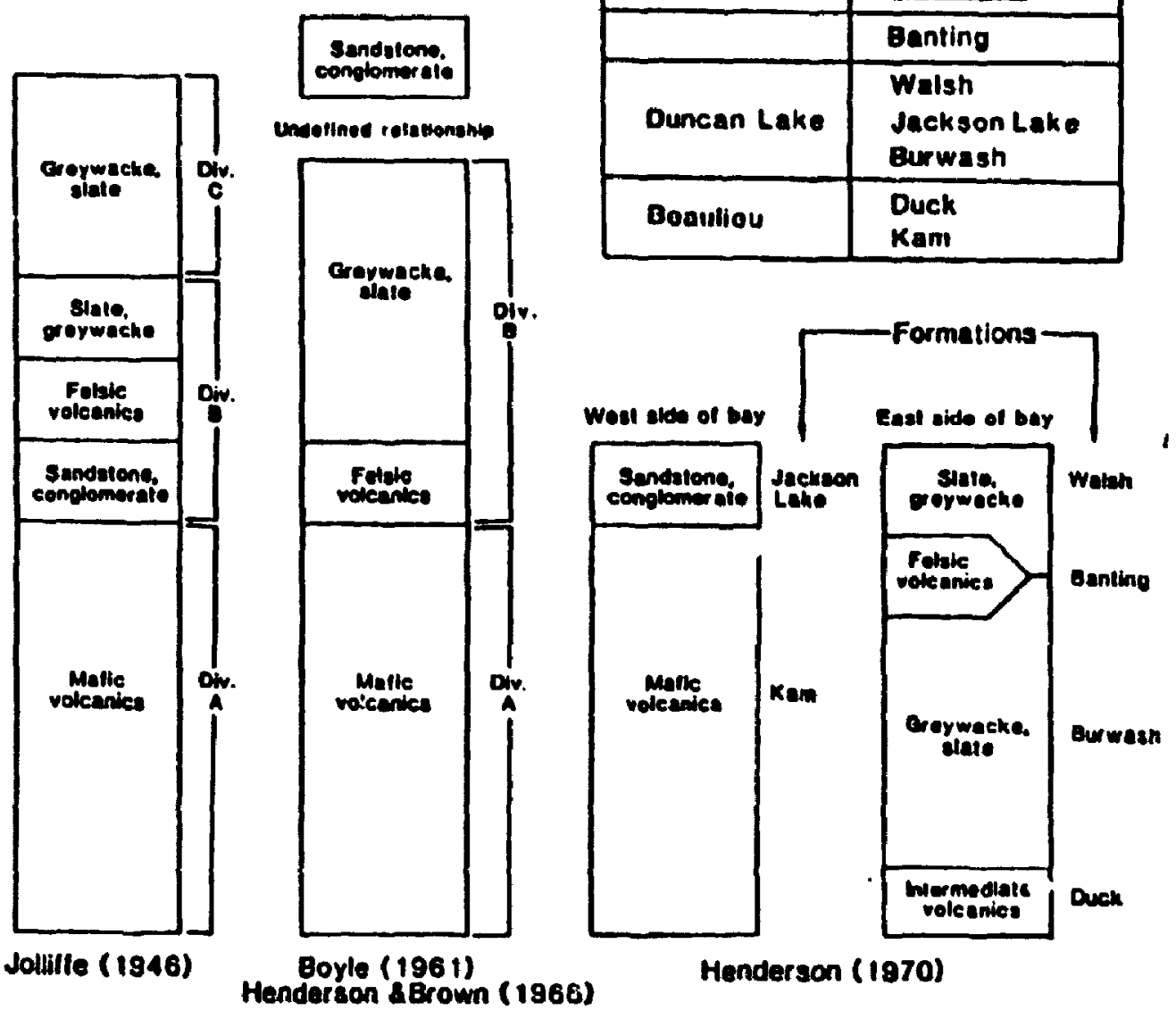


that unconformably overlie the Kam Formation on the west side of the Bay are Interpreted as lateral facies equivalents of the greywacke and slates of the Burwash Formation. The mainly felsic volcanle rocks of Division B have been defined as the Banting Formation, and were not assigned to either the Beaulieu or Duncan Lake Groups. These felsic rocks may form a syncline, the core of which is occupled by turbidites of the Walsh Formation. The formation at Walsh Lake is assumed to be the youngest unit in the area (Henderson, 1970).

The stratigraphy of the Yellowknife Supergroup was further revised by Helmstaedt and Padgham (1986a) (Figure 4). One new unit, the Octopus Formation, was added and the thick Kam Formation was divided into four formations and raised to group status, replacing the Beaulieu Group in the Yellowknife area. The Banting Formation was also given group status. Although the Duck Formation may be a lateral equivalent of the Kam and/or Banting Groups, the Duck Formation was assigned to the Duncan Lake Group, because it is imbedded in greywacke of the Burwash Formation. The position of the Jackson Lake Formation was returned to the position Henderson and Brown (1966) had suggested and is now considered to be the youngest formation of the Yellowknite Supergroup. The most recent amendments by Padgham (1987b), included the informal defizition of the basal Likely formation, now renamed the Dwyer Formation.

\section{Stratigraphy}

The Yellowknife belt lacks in situ examples of bassment rocks. The only evidence for pre-Yellowknife rocks are xenoliths in a diatreme breccia at the Con Mine, south of Yellowknife. The oldest radiometric date was yielded by a gnelssic tonalite boulder sample from a west-dipping dyke in the Yellowknife Bay Formation. ${ }^{201} \mathrm{~Pb}$. ${ }^{200} \mathrm{~Pb}$ date of 3.210 Ga was obtained from zircons in the tonalite boulder. Zircons from a quartz monzonite boulder from the same dyke yielded a ${ }^{201} \mathrm{~Pb}-{ }^{200} \mathrm{~Pb}$ date of $2.57 \mathrm{Ga}$. The presence of pre-Yellowknife xenoliths confirms the existence of an earlier sialic crust on 
Figure 4. 


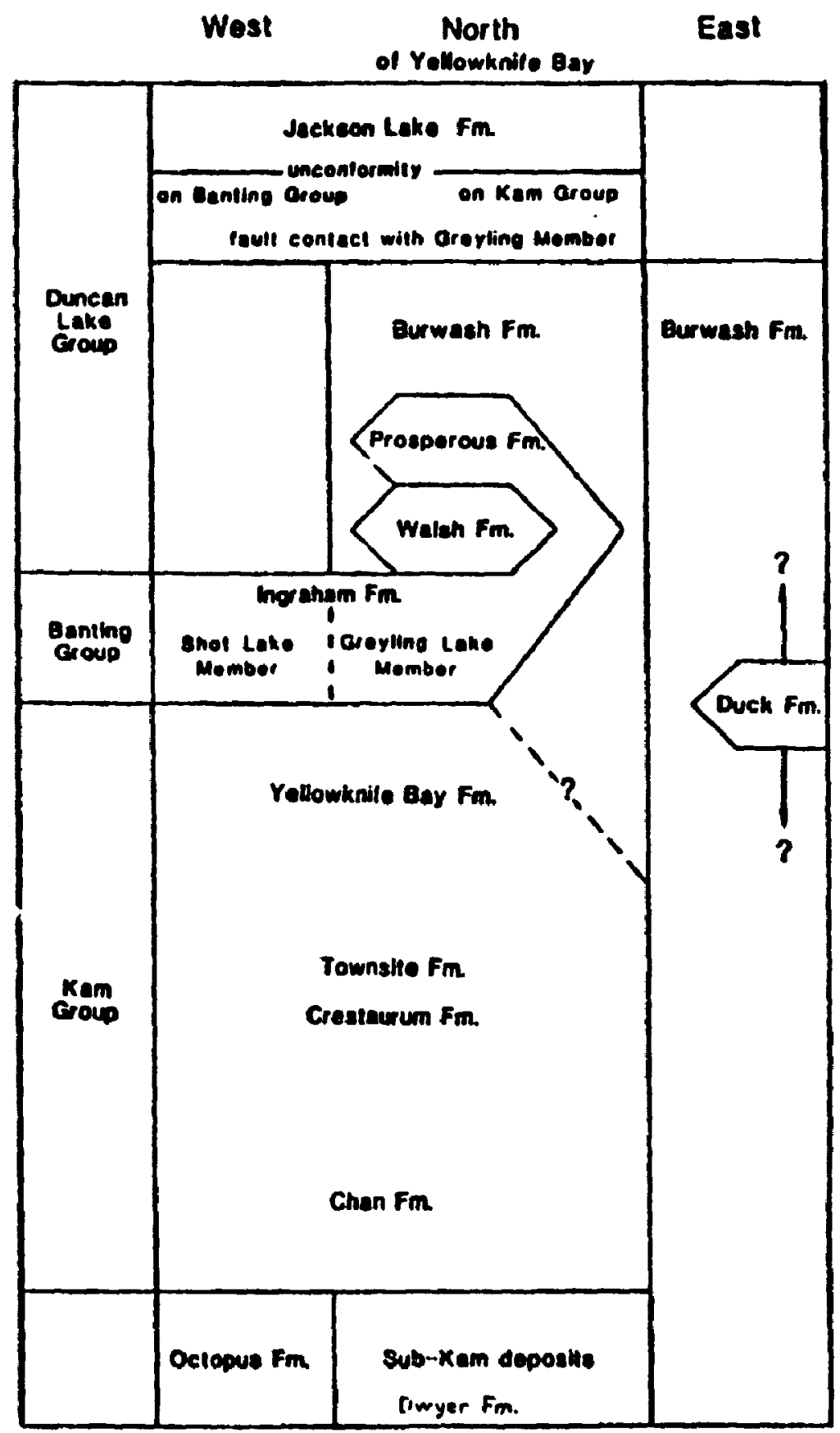


top of which the volcanics were deposited (Nikic et al., 1980;

Helmstaedt \& Padgham, 1986a; Webb, 1987).

Preliminary dating (U-Pb) of the basement terranes near Yellowknife, indlcates an age slightly older than the Yellowknife Supergroup $(2.648 \pm .012,2.707 \pm .024 \mathrm{Ga})$ for the Anton Complex on the west and $2.7 \mathrm{Ga}$ for the Sleepy Dragon Complex on the east (Bailey, 1987a; Isaachsen et al., 1989).

The lowermost stratigraphic unit in the Yellowknife area, the Duyer formation, is confined to the northern end of the belt, southeast of Duyer Lake (Figure 5). At the potential type section for the Dwyer formation, the basal units are present as large xenoliths in granodiorite of the Anton Complex. Topping directions have not been determined for the Dwyer formation and stratigraphy is based on the topping of the overlying Kam Group. The 2-3 m long blocks of poorly-layered quartzite give way to a narrow zone of lit-par-lit structures where the granodiorite intrudes the basal quartzite. The isoclinally folded quartzite varies from a massive quartz-rich fuchsite-bearing sandstone to a lithic arenite. Few sedimentary structures are present but concretions become more common where the sediments are interbedded with garnet-gedrite rich layers. The proportion of iron-rich layers increases upward to thin beds of banded chertmagnetite iron-formation. Overlying the beds are thick layers of felsic pyroclastic flows with features suggestive of flow banding. Interbedded with the felsic units are 1-2 $\mathrm{m}$ thick beds of thinly-banded chert-magnetite iron-formation. Overlying the felsic unit are pillows belonging to the Chan Formation of the Kam Group. The contact has been obscured by the intrusion of a gabbroic sill.

The pre-Kam supracrustal rocks of the Dwyer formation mark an early period of sedimentation from an uplifted pre-Yellowknife Supergroup basement accompanied by contemporaneous felsic volcanism. The felsic volcanism may represent basin development before formation of deep fractures that tapped mafic magma reservolrs that formed the Kam Group. Similar basal deposits have been described in the Beaulieu River area by Roach and Fyson (1988).

The Octopus formation is another unit which was proposed as basement to the 
Introduction to Yellowknife Geology

16

Figure 5. 


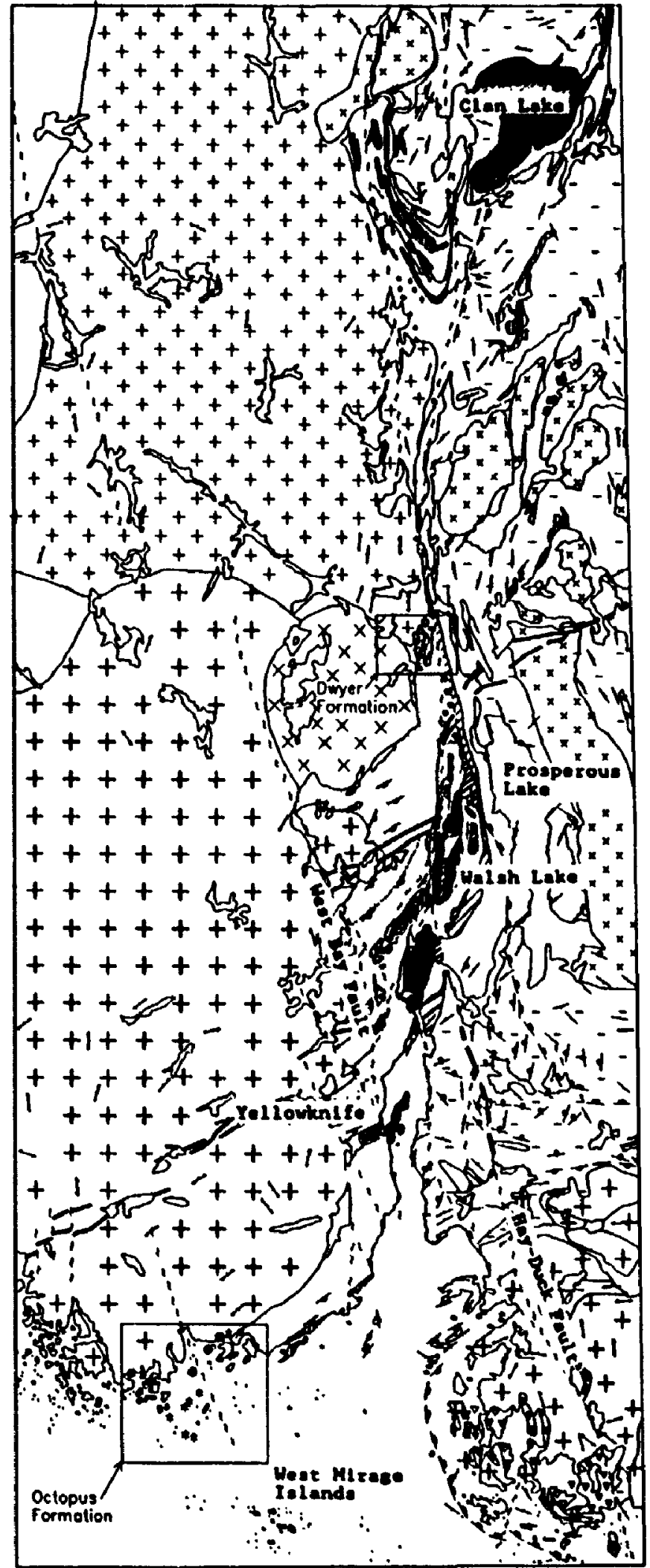

\section{Prolerozole}

Proterozoic Dykes

\section{Archeon}

Ex: Prosperous Loke Gronile

$x x$ Duckfish Lake Granite

E.? Wool Boy Diorile

$t$ Defeat Plutonic Complex

++ Anton Complex

$[00]$ Jockson Loke Formotion

$\because \because$ Burwosh Formotion

\section{Banting Group}

$Q 7$ Prosperol ; irmotion

QID Wolsh Formation

VIII Ingrohom formation

* Octopus Formation

\section{Kam Groun}

III Gabbro Sills

$\square$ Yellowknife Boy Formotion

Townsite Formation

$\square$ Crestourum Formotion

$\square$ Chan Formotion

Pre-Kam Group
Dwyer Formation

$\cdots$ - Iron formation

SYMBOLS

Lote Foults

Contocts

Foliation Dip

\section{Unknown \\ Inclined \\ Vertical}

Bedding Pillows Tops Known

Bedding Dip Tops Known

Inclined

Vertical

Overturned

Bedding Dip Tops Unknown

Unknown

Inclined

Cordierite Isograd $\approx$

$=$
\pm
\pm
\pm 
mafic volcanics of the Kam Group. The Octopus Formation forms a 750 metre-thick lens, along the edge of the Western Plutonic Complex, the extends through the ialands at the southwest end of Yellowknife Bay. Named after Octopus Lake, the Octopus Formation was first recognized as inclusions in younger granodiorite masses. Due to coverage by Great Slave Lake, no complete section of the formation is exposed (Helmstaedt et al., 1979; 1981; Pelletier \& Wahlroth, 1986).

Most of the Octopus Formation is dominated by mafic gneiss with a distinctively high biotite content, metamorphosed to amphibolite facies. Above the amphibolite is a 75 metre-thick package of greywacke, siltstone and conglomerate. Pebbles in the conglomerate are mainly metasedimentary but include amphibolite, felsic volcanics, and rare granitoid fragments suspected to be of basement origin. The Octopus Formation shows bedding-parallel foliation and localized isoclinal folds, both discordant to bedding in the overlying Kam Group. Intrusion by granodiorite plutons has destroyed the lower contact. The upper contact has not been observed directly, and its stratigraphic position is unconfirmed. The Octopus Formation has been ?icerpreted as a remnant of a pre-Kam volcanic cycle, tilted betore Kam Group deposition (Helmstaedt et al., 1979; Helmstaedt \& Padgham, 1986a). Alternatively, the Octopus Formation has been interpreted as a lateral facies of the Yellowknife Bay Formation or as a precursor olistostrome or melange related to subduction of the greenstone belt (Kusky, 1987).

The Kam Group is a northeasterly striking, homoclinal sequence of mafic flows and tufts, younging towards Great Slave Lake to the southeast. With a total thlckness estimated to be 10-12 km, the Kam has been divided into four distinct units: the Chan, Crestaurum, Townsite and Yellowknife Bay Formations.

The Chan Formation is the basal unit of the Kam Group (Figure 5). Seven to elight kilometres thick, it is exposed mainly in the northern part of the Volcanic Belt. At the base, a sheet-like body of massive to layered gabbro with xenollths of leucogabbro and anorthositic gabbro has intruded overlying flows. The anorthositic gabbro is strongly 
sheared and follated and locally contains roundad plagloclase cryatals up to $20 \mathrm{~cm}$ in diameter. Multiple northwest trending dykes, and irregularty shaped intrustons of gabbro have also Intruded pillow thowe and precerved screens of pillowe. Many dykes have intruded earlier dykes, resulting in multiple chilled margins, whereas the irregular bodbes show gradational relationships with the flowe. The northwest strike of the dykes in the Chan Formation indicates northeast-southweat extension, subparallel to the intrualve contact of the Western Granodiortte. Based on the proportion of dykes, the intrusive events must have involved at least $10 \%$ lateral oxtension. At Berry Hill, the upper Chan Formation has been highly sliciciled and carbonated, possibly by fumarolic activity. The upper Chan boundary is at the "Ranney Chert" as defined by Henderson and Brown (1966). The "Ranney Chert", which is the first laterally extensive marker bed, represents a widespread interval of felsic volcanism and sedimentation (Helmstaedt \& Padgham, 1986a).

The Crestaurum Formation, conformably overlying the Chan Formation, is characterized by massive and pillowed basalt with thin, laterally continuous felsic tulfis and rhyodacitic flows. Two variolitic pillow flows, the Stock and Fox flows, are distinctive markers, with varioles consisting of fine-grained intergrowths of epidote, hornblende and plagioclase in centimetre-sized spheres clustered around the pillow rims. At the Crestaurum Mine site, thinly bedded fine-grained cherty fuffs or silicified turbidites have been deformed by penecontemporaneous slumping. A distinctive Irregular zone of silicified basalt within the Crestaurum Formation weathers a distinctive white, and may represent a zone of hydrothermal alteration. Metagabbro dykes in the Crestaurum Formation form prominent north trending swarm, comprising $10 \%$ of the unit. The upper boundary is defined at the contact with the dacitic Townsite Formation (Henderson \& Brown, 1966; Helmstaedt \& Padghamr, 1986a).

The "Townsite Hows", renamed the Townsite Formation, are composed of thyolite breccla, welded tults and andesitic pillows, intruded by a coarse-grained, homogeneous 
metagabbro sll complox. The formation is eeparated into two lenses by the Giant Shear syatem, with the Niven Lake lone north of the city of Yellowknife and its faulted oxtension, the Brock Flows, northwest of the Clant Mine property. The second lens liee near Vee Lake, north of the Giant Mine. The bulk chemietry is calc-alkaline and qulte distinct from the surrounding tholeltitc basalt. Littie of the upper contact is exposed, and the remainder is highly sheared (Baragar, 1966; Helmstaedt \& Padgham, 1986a).

The Yellowknite Bay Formation, conformably on the Townsite Formation, is well exposed along the west shore of Yellowknife Bay. The lower Yellowknife Bey Formation is an agglomeration of lenticular tholelitic basalt deposits. Among these deposits are the distinctive variolitic Negus and Yellorex Flows which provide an important basis for correlations. Other marker beds are thin laterally-extensive beds of sediments between the lenticular volcanic units. The total thickness of this formation is not known because no complete section of the Yellowknite Bay Formation is exposed, and the sequence has been extensively cut by faults of several ages. At Giant Mine, the Yellowknife Bay Formation is only one kilometre thick, whereas to the south it is at least $5 \mathrm{~km}$ thick. The difference may be due to displacement and/or attenuation in the Giant Shear Zones, which occur near the base of the Yellowknife Bay Formation.

In the lower Yellowknife Bay Formation, cherty tuff and tuffs are common sediments, whereas higher in the sequence, turbiditic sandstones are more prevalent. The formation has been intruded by a swarm of metagabbro dykes, similar to the dyke swarm in the Crestaurum Formation, but fed by gabbro sills in the Townsite Formation. The complex upper contact of the Yellowknife Bay Formation is the subject of several conflicting hypotheses. The transition from the Kam Group to the Banting Group is marked by abundant quartzose turbiditic sandstones and metagabbro sills which are interlayered with and locally engulfed by pillow flows. The lateral persistence of this sillturbidite-flow assemblage suggests that fissure-eruptions produced the upper parts of the Yellowknife Bay Formation. Elsewhere, the contact is marked by an erosional 
unconformity with the Jacksion Lake Formatton or by fault contacts (Baragar, 1975; Henderson \& Brown, 1967).

Direct dating of the Kam Group b dificult due to the lack of felale units with abundant zircons and motamorphlc recetting of radiometric datos. A U-Pb dato of $2.65 \mathrm{Ga}$ has been obtained from a zircon in a felsic outcrop beneath the Explorer Hotel in the Townsite Formation (Padgham, 1987c). A multitude of quartz-plagloclase phyric dacitic dykes cut through the Crestaurum Formation in the northern part of the Belt. These dykes, yielding zircon U-Pb dates of $2.678 \pm .008 \mathrm{Ga}$ and $2.667 \pm .004 \mathrm{Ga}$, provide a minimum age for the Kam Group (Helmstaedt \& Padgham, 1986a). Rb-Sr age determinations of rocks from the Kam Group, may be reset (Easton, 1984). Other reset ages include a whole rock Rb-Sr age of $2.570 \pm .160 \mathrm{Ga}$ for basic metavolcanic rocks (Green et al., 1968), a whole rock Rb-Sr age of $2.567 \pm .01$ Ga for the Townsite Formation (Lambert, 1984) and a whole rock U.Pb age of 2.608 Ga for the Townsite Formation (Green \& Baadsgaard, 1971).

Major element chemical analyses across the Kam Group show two cycles of mafic volcanism abruptly culminating with calc-alkaline volcanism of the Townsite Formation and the basal formation of the Banting Group. The Kam Group is interpreted to be of mantle derivation. A strong tholeiltlc trend exists, with compositions ranging from magnesian basalt to high-iron tholeiitic basalt. Although there is no overall decrease in the $\mathrm{MgO/FeO}$ (total) ratio with increasing height, several iron enrichment trends persist for several thousand metres in the mafic volcanic hows. Baragar (1966) attributed these trends to fractional crystallization in a succession of high-level magma chambers. The change from basic volcanism to calc-alkaline volcanism at the top of the Kam Group was attributed to contamination of tholelitic magmas by sialic crust (Cunningham, 1984).

Alternatlvely the Kam Group rocks may have had a different source than the bulk of the Banting Group, with little differentiation of the Kam source magma occurring during accumulation of the volcanic pile. Green and Baadsgaard (1971) interproted low 
"Sr-"Sr Initial ratios from whole rock enalyses of volcanic rocks as indicative of dervation from the upper manth without eny eignificant crustel contamination (Jenner at al., 1981).

The Kam Group evolved as a southward-prograding succession of volcanic centres controlled by a faulted margin (Henderson, 1985). The present form of the volcanic befi suggests that the Chan Formation formed as a shield volcano. The clocelyspeced mafic dykes in the Chan Formation prompted Helmstaedt and Padgham (1986a) to comment on the similarity of the Chan Formation to sheeled dyke sequences in ophiolites. "Budding" into pillows from some of the dykes, has been noted, suggesting that the dykes acted as a feeder system to the flows, extruding magma onto the sea-floor (Helmstaedt et al.,1986).

The Crestaurum Formation erupted from a new set of fissures on the southern flank of the Chan volcanic pile. This accounts for its absence to the north of the Chan Group and greater thickness to the south. Uplift during deposition of the Crestaunum Formation was followed by the development of Townsite Formation depositional centres that may have been subaerial and thus susceptible to rapid erosion. The upper Yellowknife Bay quartz-rich sandstones, generated from an emergent calc-alkaline central volcanic complex, were contemporaneous with sheeted and multiple gabbrolc dykes that fed flows, sills and flow-sill complexes. Extensive erosion of the Kam edifice during deposition of the Banting Group may also have been responsible for the deposition of abundant sedimentary rocks rich in mafic to intermediate volcanic clasts that have been studied in the West Mirage Islands by Relf and Nicolson (1986).

The dominanthy pyroclastic Banting Group overlies the Kam Group. Recent mapping has divided the Banting Group into the Ingraham, Walsh and Prosperous Formations. The basis for differentiating the Banting Group from the tholeiltic Kam Group is the calc-alkaline nature of the younger units (Bailey, 1987a).

From the Giant Section south, the Banting Group lies conformably on the Yellowknife Bay Formation. The north end of the Belt was uplifted and eroded while 
basaltic volcaniem wes still dopoelting the Yellowknlfo Bay Formation to the south. The Banting Group is exposed on the mainland south of Kam Point and on many lilande to the southeast, and additional information is provided by boreholes bencath Yollowknite Bay. Outcrops on the Weat Mirage blands sleo have been correlated with the Banting Group (Relf \& Nicolson, 1986). A reconstruction of the Banting Group by Bailoy (1987a) defines three broad volcanic settings, the central, proximal and distal faclos.

The beseal Banting unit, the Ingraham Formation, consists mainly of wolded tuffes and coarse brecclas. Tis: southern part of the Ingraham Formation, the Shot Lake Member, is exposed along the west side of Walsh Lake. The base of the Shot Lake Member is either not exposed or is in fault contact with the Jackson Lake Formation. The lowest ur, it, a basal quartz-feldspar porphyry, is overlain by mafic lavas, pillowed breccia, felsic fragmental flows, and welded tuffe interlayered with paraconglomerate. The proportion of conglomerate to volcanic rocks increases up-section to a 60 motre-thick cap of conglomerate. The matrix-supported conglomerate contains subangular to subrounded clasts of sandstone, siltstone, and felsic volcanic rocks. To the south, the Shot Lake Member is a thick unit of woll-bodded ash flows intruded by maflc sills (Helmstaedt \& Padgham, 1986a; Easton \& Jackson, 1981).

The Greyling Lake Member is similar to the Shot Lake Member but the two members are separated by the Hay-Duck fault. The base of the Greyling Lake Member is not exposed. Volcaniclastic and tufleceous sediments in the lower part of the Greyling Lake member are intruded by a sill of quartz-feldspar porphyry; these are overiain by felsic and intermediate tuffs and flows intercalated with pillowed flows. The plllow lavas and ash flows grade into cherty tuffs with thin layers of chloritic schist and amphibolites, capped by ash flows with fiamme-like inclusions.

Conformably overlying both members of the Ingraham Formation is the Walsh Formation, a succession of fine-grained argillites. These thin-bedded turbiditic sediments superticially resemble the Burwash Formation, but the sandy beds are much thinner than 
in the more widespread Bunwash Formation. The Walsh Formation accumulated in a shallow proximal bacin, and represents en Imberingering of the overtying Bunwach furbidte sequence with volcaniclastice of the Ingraham and Prosperous Formatlons (Holmstaodt \& Pedgham, 1886a).

The Walsh Formation ls seperated from the Burwash Formation by the Prosperous Formation. Named after Prosperous Lake, the formation is dominated by folsic tulf interbedded with mafic flows, with turbidites and some conglomerate beds between many of the volcanic beds. The formation has a lenticular appearance, and interfingers with both the underlying Walsh and the overtying Bumash sediments. The lack of lataral continuity of beds in the Prosperous Formation suggests an origin as a submarine gravity flow/slump deposit, with volcanic rocks representing intermittent igneous evente (Helmstaedt \& Padgham, 1986a). The Prosperous Formation pinches out at the southwestern end of Walsh Lake, where it is overlain by the Burwash Formation. The transition is marked by $30 \mathrm{~m}$ zone of sulphide-rich argillite containing several pods of massive pyrite.

The fow radiometric ages so far delermined for rocks of the Banting Group include a U-Pb zircon age of $2.667 \pm .004$ Ga for a felsic porphyritic flow in the Shot Lake Member of the Ingraham Formation, and a suspect whole rock $\mathrm{Rb}-\mathrm{Sr}$ age of $2.519 \pm .012 \mathrm{Ga}$ from the Ingraham Formation (Lambert, 1984). Yellowknife area whole rock K-Ar and Rb-Sr age determinations clustered about 2.5-2.575 Ga may be the result of motamorphic resetting (Easton, 1984). The U-Pb zircon dates from the Banting are nearly identical to dates from quartz-plagioclase phyric dykes cutting the Kam Group, supporting the suggestion that the dykes may be related to Banting Group volcanism. (Bailey, 1987b; Padgham, 1987b)

The chemical composition of Banting and Kam Group rocks have been interpreted 
Introduction to Yellowknife Geology

25

Figure 6. 
Introduction to Yellowknife Geology

26

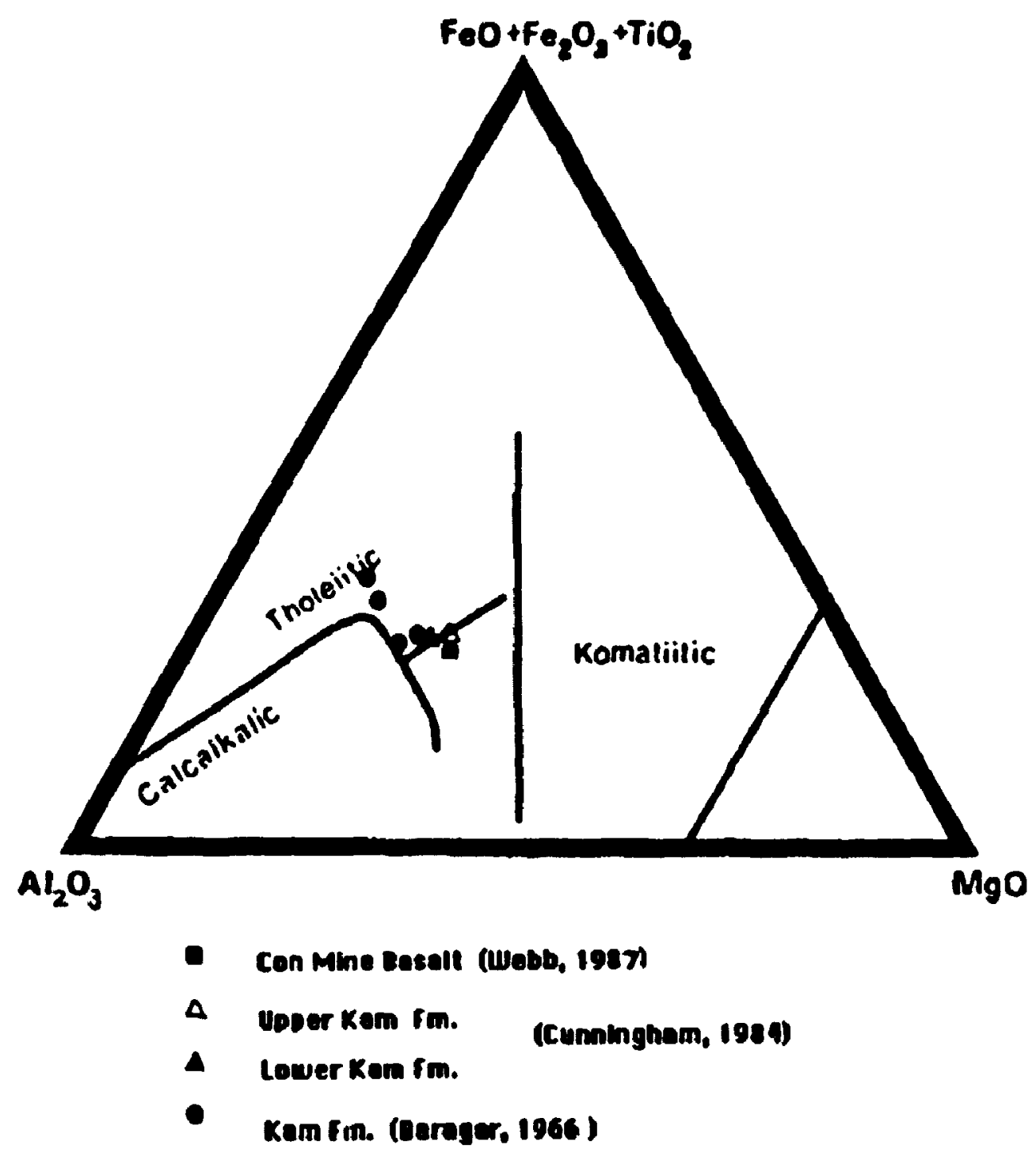


to be distinctly different. Ternary plots $\left(F_{o}+\pi, A, M g\right)$ show that the Kam Group falls within the tholeilitic field (Flgure 6). Banting Group samples have compositions which are higher in alumina and are close to the calc-alkaline/tholeiitic boundary. Towneite Formation samples are the only Kam Group rocks that plot near the Banting Group. Based on rare-earth studies, Jenner of al., (1881) and Cunningham (1984) attributed volcanic rocks of the Banting Group to partid melting of a basaltic source, followed by partial melting of an amphibolite.

With initiation of felsic volcaniem at the basin margins and at the basin contre, a new quartz-rich sediment source was avalable. The bulk of the greywacke-mudstone basin infilling was a consequence of this socond phase of volcanism, and may have boen associated with the beginning of plutonism in the area (Henderson, 1985). The dykes probably acted as the subvolcanic condult system that fed felsic flows in the Banting Group. Zircon age determinations of the Banting Group show that it was coeval with the felsic rocks of the Hackett River Domain, and a pan-Slave event may account for the uniformity of felsic volcanism ages (Fyson \& Helmstaedt, 1988).

West of the Yellowknife volcanic belt, the Yellowknife basin is filled mainly by sediments of the Burwash Formation, but also contains isolated embedded volcanic units. These volcanic units are corisidered to be lateral equivalents to the Yellowknife belt. The Duck Formation outcrops on the eastern side of Yellowknife Bay. The lithology of the Duck Formation is similar to the Kam Group, with abundant pillowed flows separated by pillow breccia, interfiow cherts and porphyritic felsic sills. Henderson (1970) considered the Duck Formation to be an extension of the Kam Group, but Helmstaedt and Padgham (1986a), although not discounting this possibility, preferred to separate the two units. The Duck Formation may represent localized basaltic volcanism outboars of the main rifting of the Kam and Banting Groups. A whole rock age of $2.30 \pm .13$ Ga (Lambert, 1984) supports the suggestion that the Duck Formation is younger than some or all Kam Group rocks.

The Clan Lake Complex north of Yellowknife is a central felsic volcano complex that also rests on and interingers with the Bunwash Formation (Hurdle, 1984; 1987). 
The Burwash Formation, the moet extenaive unit in the Yellowknife Supergroup. does not contain any laterally continuous or distinctive marker beds, and cannot be further subdivided. The total Bunwash Formation thickness has bee.i estimated at about 4500 metres, and the contact between the volcanics and the sediments is sharp, with little or no recurrence of volcanic units within the Burwash (Henderson, 1972).

The Bunwash Formation consists almoet exclusively of greywacke and mudstone metamorphosed up to amphibolite grade, but many primary sedimentary features associated with a turbiditic origin are apparent (Henderson, 1987). Greywacke and mudstone couplets form the basic sedimentary unit of the formation, where most beds grade either continuously from sand size to clay size, or discontinuously with grading restricted to part of a bed or varying abruptly. Individual beds are laterally continuous and typically maintain a constant thickness across exposures. The bases are sharply bounded with small scours and channels infilled by cross-bedded sands. Loading and dewatering structures and rip-up mud clasts imply deposition from grain flows, where the sediment mass is kept mobile by grains bouncing off each other, and the grains are not supported by fluid turbulence, as happens with true turbidity currents (ct. Middleton \& Hampton, 1973).

Detrital zircons from the Burwash Formation have been dated at $2.680 \mathrm{Ga}$ (Wanless, 1970). These reflect the source of the Burwash turbidites, the felsic to intermediate volcanism contemporaneous with sedimentation. A small population of zircons is considered to have originated from granitoid basement units. The high proportion of volcanic rock fragments, particularly silicic-volcanic lithic clasts, along with abundant quartz and feldspar and the minor but ubiquitous granitic rock fragments in the greywacke, suggest a mixed silicic-volcanic and granitic source. Accumulation occurred in depositional fan valleys on a submarine fan complex near the margin of the sedimentary basin east of Yellowknife (Henderson, 1972; 1987).

The youngest of the supracrustal units in the Yellowknife region is the Jackson 
Lake Formation, containing a diversity of sediments ranging from cobble-sized conglomerates to well-bedded mudstones and wackes. A conglomerate with a localized distribution forms the basal unit; the remainder consists of fine- to medium-grained crosebedded sandstone with conglomerate lenses. The sandstone is a greywacke with a high quartz content distinguishing it from Bunwash Formation sandstones. The conglomerate clasts are mainly Kam Group volcanic fragments and abundant granitoid claste, and a wide variety of minor lithologies including vein quartz, lasper and iron formation. The source of porphyritic granite clasts has not been identified, but texturally they resemble the roof of the Western Plutonic Complex (D.J. Atkinson, personal communication, 1989). South of Yellowknife on the Con Property, the Kam Group is truncated by a regolith upon which sediments assigned to the Jackson Lake Formation have been deposited (Bullis of al., 1987).

The Jackson Lake Formation is cut by shear zones northeast of the Giant Section, and on islands in Yellowknife Bay. Where the Giant Shear Zone meets the Jackson Lake unconformity there is no offset, suggesting truncation of the shear zone at the unconformity. Alternative interpretations have the shear zone merge into the unconformity, with the associated displacement taken up by slippage along bedding planes above the unconformity. At the Glant Section, foliation parallel to bedding in interflow sediments crosses the unconformity, Intersecting bedding in the Jackson Lake Formation. A left-lateral shear component along the unconformity is suggested, which is compatible with displacement observed along the Giant Shear. Granitoid intrusion after deposition of the Banting Group further lifted the volcanic belt, leading to the erosional unroofing of some granitoid plutons. The penetrative fabric in the conglomerate and the underlying Kam Group may be related to later intrusion of the main phase of the Western Granodiorite. The age of the Jackson Lake Formation as well as its stratigraphic position is contentious. It has a maximum age of $2.554 \mathrm{Ga}$, limited by a U-Pb age on a zircon from a diorite boulder in the conglomerate inferred to have originated from the Weatern 
Granodiorite (Green \& Baadsgaard, 1971).

Pettljohn (1970) suggested that the formation resembles Timiskaming-type conglomerates of the Superior Province, and was deposited in a fault contrelled besin. The faull-bounded besin coincided in the northern part of the Yellowknife Volcanic Belt with the Kam-Banting unconformity. Eroalon and weathering excavated the Kam-Banting boundary to the point that the sub-Jackeon Lake unconformity appears to be parallel with bedding in the Banting Group, and at high angles to bedding in the Kam Group (Helmstaedt \& Padgham, 1986a).

Only two granitoid suites, the Defeat Plutonic Sulte and the Prosperous Granites, are present in the Yellowknife area. One of the smaller granites, the Duckfish Granite, crops out $18 \mathrm{~km}$ north of Yellowknife. The Duckfish is a large stock of white to pink, biotite-poor, coarse-grained to porphyritic granite. The Defeat Plutonic Suite is one of the three suites that form a large granitoid batholith extending $70 \mathrm{~km}$ northwest from Yellowknife, named the Western Granodiorite. It is a white to dark red massive mediumgrained biotite granodiorite to tonalite with hornblende. The Prosperous Granite, a massive, white to pink, medium-grained biotite-muscovite monzogranite that is locally pegmatitic, outcrops near Prosperous Lake (Meintzer \& Wise, 1987).

In the Yellowknife Belt the intrusive contact with the younger plutonic suites is discordant, cutting across the entire 10 kilometre-thick section of Kam Group. At numerous localities along the contact, large xenoliths of mafic rocks in the batholith and aginatitic brecclas suggest that parts of the mafic sequence subsided into the batholith (Fyson \& Helmstaedt, 1988).

The Western Granodiorite has yielded an age of $2.555 \mathrm{Ga}$ from $\mathrm{Rb}-\mathrm{Sr}$ isochron (Green et al., 1968) and from a discordant plot of zircon data (Green \& Baadsgaard, 1971). More recent zircon dates of the Western Granodiorite give a U-Pb age of $2.596 \pm .016 \mathrm{Ga}$ (Bullis of al., 1987). Pb-Pb ages of $2.675 \pm .004 \mathrm{Ma}$ and 2.64 Ga have also been determined for the Western Granodiorite by Thorpe (1971) and 
Cumming and Teong (1975) respectively. Other large granitic bodles in the Yollowknite region have yielded younger ages, including $₫ 2.521 \pm .0025 \mathrm{Ga} \mathrm{Rb}-\mathrm{Sr}$ mineral ieochron for the Prosperous Lake Granite (Green et al., 1868).

The youngest intrusions in the Yellowknife area are Proterozoic diabese dykes belonging to three sets, all cut by later faulting. Overlapping ages have been determined by means of isotopic dating. Crose-cutting relationships suggest that the eastnortheasterly trending Dogrib Dykes are older than dykes of the Indin Swarm (Easton, 1984; Henderson, 1985).

Dykes of the Indin Swarm form northwesterly and north-northeasterly trending conjugate sets. This identlfication is based on similar K-Ar ages, palaeomagnetic pole positions, and conflicting crosscutting relationships (Henderson, 1985). A single eastdipping mafic sheet-like intrusion in the metasediments of the Burwash Formation east of Yellowknife Bay, callod the Mitt Diabase, has been cut by the Hay-Duck Fault, but its relationship to other diabase intrusions has not been establlshed (Henderson, 1885).

Although these dykes are consistently affected by faults of the West Bay Syatem, they locally follow these faults and have chilled margins against the fault gouge, suggesting overlap between faulting and dyke intrusion (Jolliffe, 1946).

\section{Metamorphism}

The margins of the Slave Province were affected by three thermal events: the Kenoran Orogeny ending by $2.5 \mathrm{Ga}$, an early Protgrczoic ovent at about $2.2 \mathrm{Ga}$, and the Hudsonian Orogeny at 2.0-1.8 Ga (Frith, 1978). The earliest deformation affected the volcanic rocks of the Yellowknife belt to the greatest degree. The next two events did not significantly disturb the metavolcanics, but the metasediments in the Yellowknife Basin underwent further deformation, resulting in complex structures (Baragar et al., 1979).

Three regional metamorphic facies are defined in the Yellowknife Greenstone Belt. The amphibolite facies and the epidote-amphibolite facies are well developed; delineation 
of the third, the greenechiat facies, is complicated by a multitude of faults and alterationrich shear-zones (Boyle, 1861).

Motasediments of the Yellowknifo Supergroup were substantially altered by regional metamorphiem. The Bunwach formation is metamorphosed everywhere to some degree; nowhere are the original minerals preserved. The pattern of metamorphlam is clearly outlined by the distribution of the cordierte isograd, which separates greenschist facies from amphibolite facies (Figure 7).

At greenschist grade the rocks are composed of assemblages of quartz, plagioclase, chlorite, white mica, biotite, opidote, cilnozoisite, and carbonate. The amphibolite grade metasediments contain assemblages of quartz, plagioclase, biotite, muscovite, cordierite, andalusite, sillimanite and rarely cummingtonite and gedrite. Locally, sillimanite occurs close to intrusions. Metasedimentary migmatite is developed between plutonic lobes, and regionally, in the northern part of the basin. The metamorphic pattern appears to have been controlled by local thermal anomalies associated with the emplacement of granitoid plutons, and therefore does not conform to a regional gradient. Rocks along the margins of the basins, particularly in proximity to large plutons, are at amphibolite grade, but the general condition of metamorphism remained the same (low pressure series) (Thompson, 1978; Henderson, 1985; 1987; Ramsay \& Kamemini, 1977).

\section{Structure}

Volcanic rocks along the western shore of Yellowknife Bay face to the southeast; beds are progressively younger from northwest to southeast. Facing directions in 
Introduction to Yellowknife Geology

33

Figure 7. 


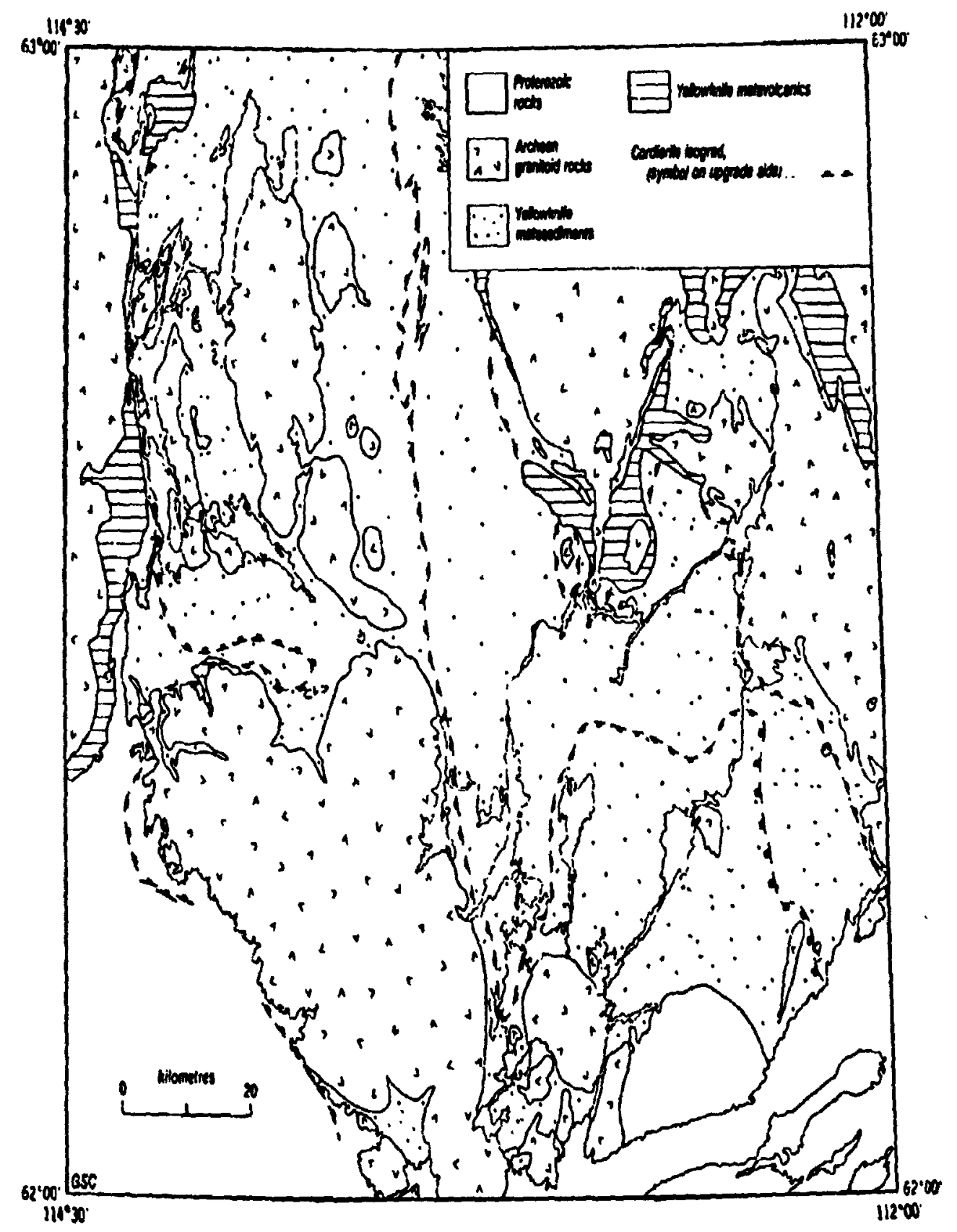


turbiditic metasediments on the east atde of the Bay are predominantly towards the weat. The axdal surface trace of an asymmetrical syncline runs through Yellowknife Bay, and north of the Bay is fault displaced east of Walch Lake, within the rocks of the Bunwash Formation (Fyson, 1887; Helmsteoct \& Padgham, 1986a; 1986b).

The principal folding event formed the homoclinal structure in the metavolcanice and caused flattening and vertical stretching of pillows and conglomerate clasts. This deformation was concurrent with emplacement of many of the granodiorite plutons and also with the peak of metamorphism. Penetrative delormation within the Kam group is strongest near the contact with the Western Granodiorite. Here pillows are flattened and strongly elongated in the dip direction of the flows, with a vertical mineral lineation defined by amphiboles. At the contact, apophyses and dykes of granodiorite in the volcanic rocks are tightly folded and boudinaged along the fabric. With distance from the contact, the metamorphic grade and penetrative strain decrease and structures change from ductile to brittle in a zone marked by an envelope of shear zones. These are the shear zones hosting the gold deposits (Thompson, 1978; Helmstaedt ef al., 1980; Fyson \& Helmstaedt, 1988).

Outside of the metavolcanic units late delormation has created complex structures. Due to its incompetence, the Burwash Formation has been extensively folded throughout the basin. The beds typically form steeply dipping isoclines with localized interference patterns. Layer-parallel foliation representing several deformation phases predominates in schist and migmatite near granitic and granodioritic plutons. Offshoots from these plutons both crosscut and are folded about the foliation, suggesting syntectonic intrusion (Fyson, 1987).

The structural succession has early folds with large-scale axial traces measurable in tens of kilometres, and smaller folds, grouped as F, structures, which extend at most a few kilometres. The $F$, folds, apparent on serial photographs, form discontinuous sets trending in different directions. Interference patterns indicate that the $F_{\text {, set includes folds }}$ 
of more than one generation. Axial plane cleavages are generally not associated with the F, folds.

Later follations crose the $F$, folds and are axial planar to minor folds common in thin beds of argillite and siltetone and in quartz veins. An easterly striking $S_{2}$ foliation Often represented by a segregation cleavage is axial planar to $F_{2}$ folds that face west. $F_{2}$

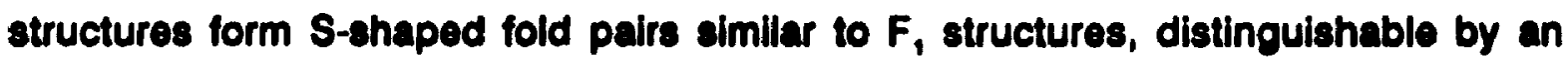
axial-planar $S_{2}$ foliation. Sedimentary structures are aligned along olther $S_{2}$ or $S_{2}$ weavages, but distinction is possible only where the $S_{3}$ sets appear together with $S_{2}$ in Outcrop (Fyson, 1987; 1982).

The Archean rocks and Proterozoic dykes which cut them have been affected by a system of strike-sllp faults named the West Bay-Indin Lake Fault System, that trend north-northwesterly more than $100 \mathrm{~km}$ into the Indin Lake area (Henderson \& Brown, 1966). Proterozoic faults strike northwest to north across the metasediments and volcanics. They range from narrow, sharply defined faults to diffuse zones of brittle fractures and minor faults. Late-stage cloavages strike northwest, parallel to the faults, both within and away from the fault zones. Metamorphic minerals (mainly muscovite and blotlte), probably of Archean age, are aligned along or overgrow the cleavages, pseudomorphing Archean structures. The Proterozoic faults may therefore follow trends established in the late Archean. Radiometric data from shear zones within the Yellowknife volcanic rocks (Lambert \& Cunningham, 1983) are in accord with both Archean and Proterozoic shearing and low-grade metamorphism (Fyson, 1987).

Near Yellowknife, the major north-northwest trending left-lateral faults West Bay, Kam-Pud, and Hay-Duck Faults) are joined by smaller "crossover" faults (Akaltcho, Martin, Townsite and Aye Faults) which also show lent-tateral strike separations. In addition, small northeasterly to southeasterly trending faults with right-lateral strike separations also are abundant. The southeasterly faults have small strike separations, and are probably hybrids between shear and extension fractures (Henderson \& Brown, 1966). 
Introduction to Yellowknife Geology

37

Because Proterozoic fault a have displaced Archean shear zones, reconstruction of the original shear zone positions was an important step in the discovery of what is now the Con Mine. Using the intersecting diabase dykes as markers, Campbell (1248) calculated the displacement of the wert eide dong the West Bay Fault to be 4920 metres south and 457 metres down relative to the cast side. Subsequent estimates have not substantially modified Campbell's results. Correction for the movement along the Wat Bay Fault led to discovery of the Campbell Shear Zone, the present source for most ore In the Con Mine, considered to be an extension of the Giant Shear Zone (Helmstaedt \& Bailey, 1987). 


\section{Introduction to the Giant Section}


The Giant Section is an extraordinarily well-exposed section through the Yellowknife volcanke belt on the west shore of Yellowknife Bay (Figure 8). Locatod northwest of Yellowknite, the Section can be approached by water from Back Bay or by road through the Giant Yellowknife Mines Ltd. plant. As the Giant Section lles easi of Glant Mine's mill and roasting plant and extends from the tailings dam to the shore of Yellowknife Bay, permission for visits should be obtained from Giant Mines Security staff.

The upper portion of the Yellowknife Bay Formation of the Kam Group comprises a 300-metre-thick sequence of pillowed flows with metagabbro dykes and sills (Figure 9). Magniffcent exposures of typical Kam Group pillow lavas, pillow breccias and interflow sediments, displaying numerous primary features can be observed. The dominantly basaltic Kam Group flows are overlain by mixed volcaniclastic sediments, ash flows and minor pillow basalts of the Banting Group. The Giant Section is the only locality where the relationship of the Yellowknife Bay Formation to the overlying Ingraham Formation of the Banting Group, and the contact of the Jackson Lake Formation to the two volcanic groups, can be examined.

The lowermost unit at the Giant Section comprises the top $\mathbf{3 0 0}$ metres of the Yellorex Member. Variolitic pillow flows are exposed in steep ridges that are crosscut by dykes of metagabbro, commonly seen on the ridge tops (Plate 1a). The pillows show a large variety of shapes and sizes, and examples with one or more interconnected buds are common. There is little interpillow material. The largest pillow at the Giant Section is over 100 metres long, but most are not longer than 1 metrs. Large pillows of 30 and 100 metre lengths can be distinguished from massive flows by a selvage along the entire pillow rim (A)'. These large pillows or "mattress pillows" are rarely seen, in part because of incomplete exposures, but mainly because of the rarity of longitudinal sections oriented parallel to the flow direction. Measurement of directional fir.w indiculors such as budding

1 Lettere refer to location shom in figure 9. 
Figure 8. 


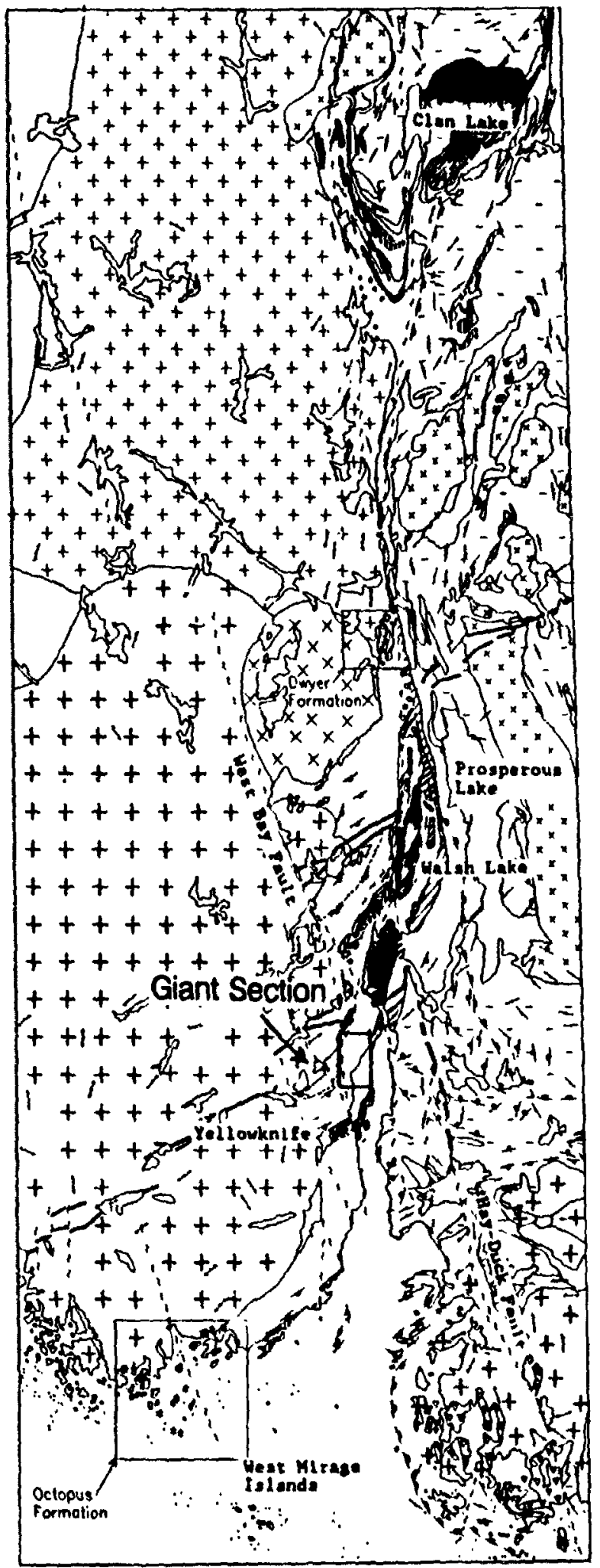

Prolerozolc

Proterozoic Dykes

Archeon

IX] Prosperous Loke Gronito

$x x$ Uuckfish Loke Gronite

E. Wool Bay Diorite

[t] Defeot Plutonic Complex

[t] Arton Complex

$\left[\begin{array}{l}\infty \\ \infty\end{array}\right]$ Jackson Lake Formolion

$E$ Eurmash Formalion

\section{Banting Group}

DD Prosperous Formotion

WA wolsh Formotion

Ingraham formotion

* Oclopus Formation

IIllil) Gabbro Silis

Yellowknile Bay Formolion

Townsite Formotion

Crestourum Formation

Chon Formation

\section{Pre-kam Croun \\ Dwyer Formotion}

$\cdots$ Iron formation

STMBOLS

Lot. Foults

Contocts

Foliation Dip

Unknown
Inclined
Vertical

Bedding Pillows Tops known

Bedding Dip Tops known

Inclined

Vertical

Overlurned

Bedding Dip Tops Unknown

Unknown

inclined

Vertical

Cordierite isogrod 
Figure 9.

\section{$\because$}




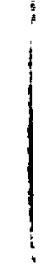

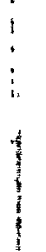

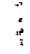

:

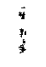

3

3
$\vdots$
$\vdots$
$\vdots$
3 


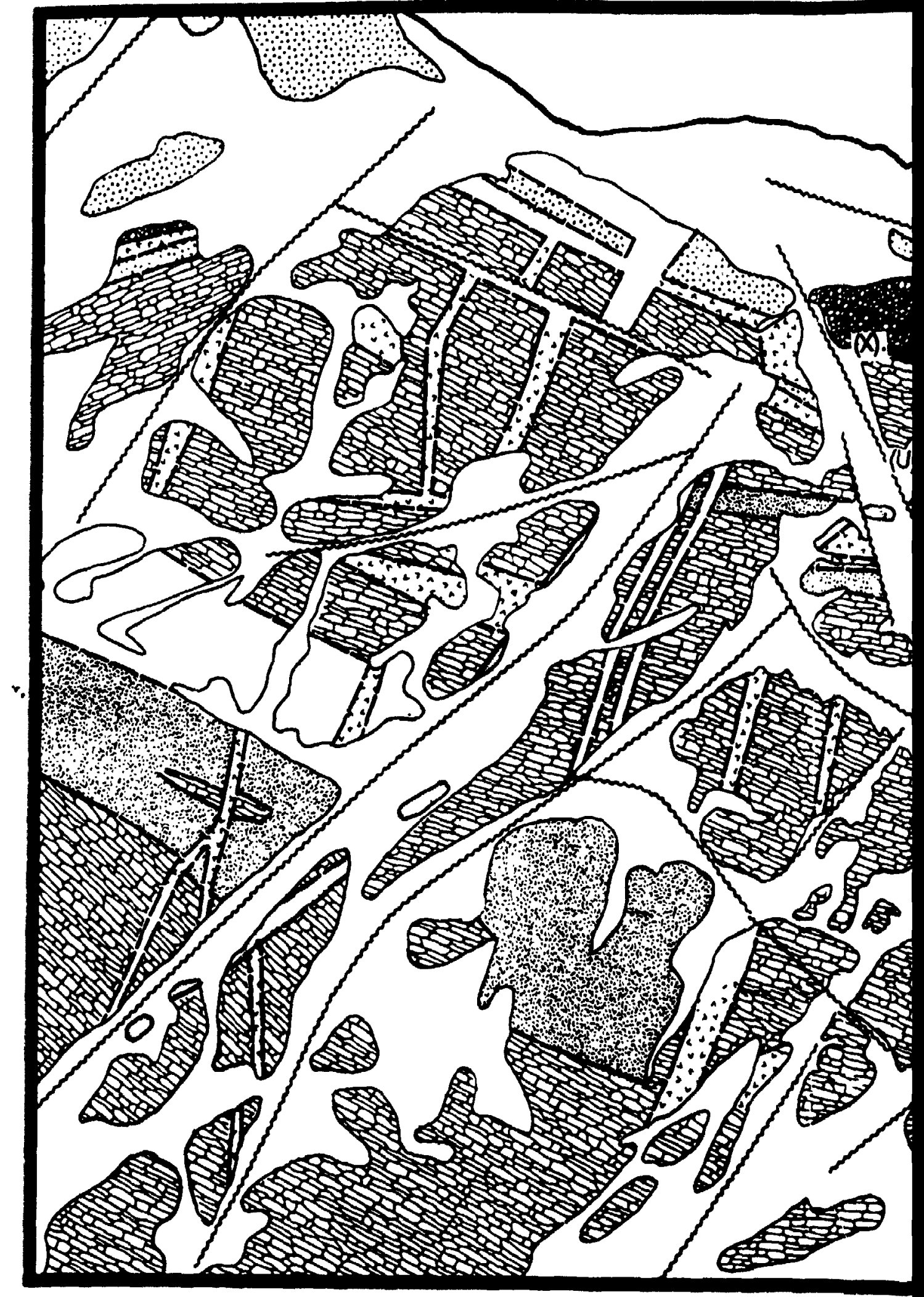




\section{YELLOWKNIFE BAY}

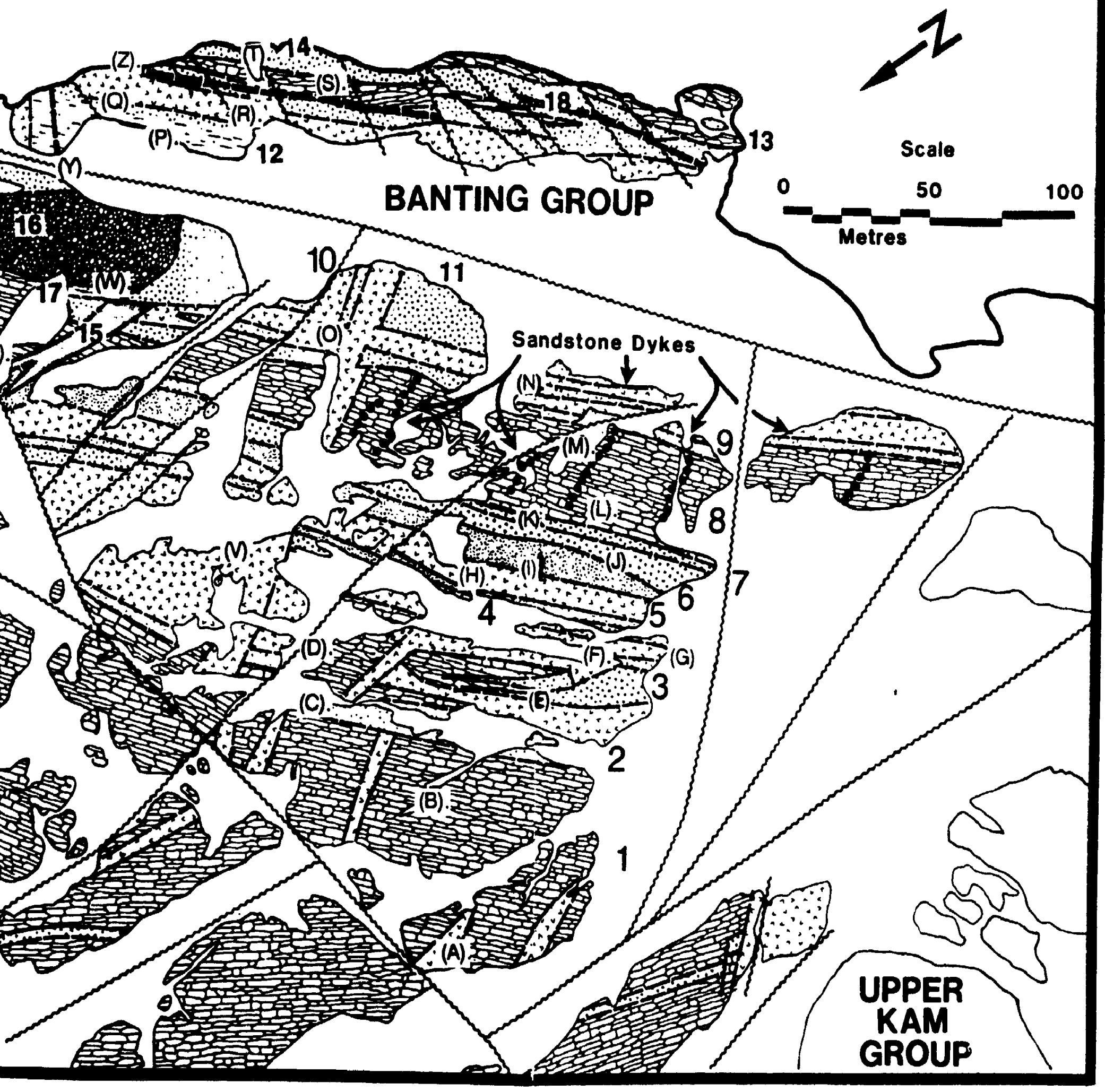


pillows has demonstrated that most flows propagated towards the southeast (Padgham, 1987c; Potts, 1988).

The pillows of the Yellorex Member are characterized by varioles of fine-grained epidote, hornblende and feldspar. The varioles tend to be more resistant to erosion than the matrix of the pillows and project out from the surface. Typical varioles are clustered around the rims which are 1 to 3 centimetres thick on average (Henderson \& Brown, 1966).

Two distinct flows of variolitic pillow lava (B) are exposed at the base of the Giant Section. Both flows display budding pillows, but only one large pillow is apparent in the upper flow. The upper flow can be separated from the lower flow on the basis of thicker pillow rims and a distinct widely spaced hexagonal jointing pattern, normal to the flow top, that may have formed by contraction during cooling. Quartz pods occupy isolated pillow interstices, and lava drainage shelves have developed where magma drained or partly drained from a lava tube (Plate 16 and $1 c$ ).

The variolitic laves of the Yellorex member are overlain by the Bode member, a tuffaceous conglomerate with abundant rhyodactic clasts $(C)$. Initially identfied as a "cherty-tuff", turbiditic characteristics have been observed in the Bode member outside of the Giant Section. In the Bode member, rounded to sub-rounded phyric rhyodacite cobbles, as well as tragments of variolitic pillows, float in a fine-grained matrix (Plate 1d). Graded bedding and cross bedding are present in the matrix, which contains flattened hyaloclastic lapilli. The boulder conglomerate fines to the southwest, suggesting that the source of the felsic clasts was to the northeast. At the Giant Section, the coarse nature of the Bode member further suggesis that a central vent is nearby.

The Bode member marks an important change in the depositional pattern within the Yellowknife Bay Formation. Below the Bode, massive and pillowed flows typical of the Kam Group predominate, whereas above, quartz-rich turbidite sands are interlayered with coarse metagabbro sills and distinctive flows. The Bode member represents a serles 
Introduction to the Giant Section

45

Plate 1. 


\section{Plate 1}

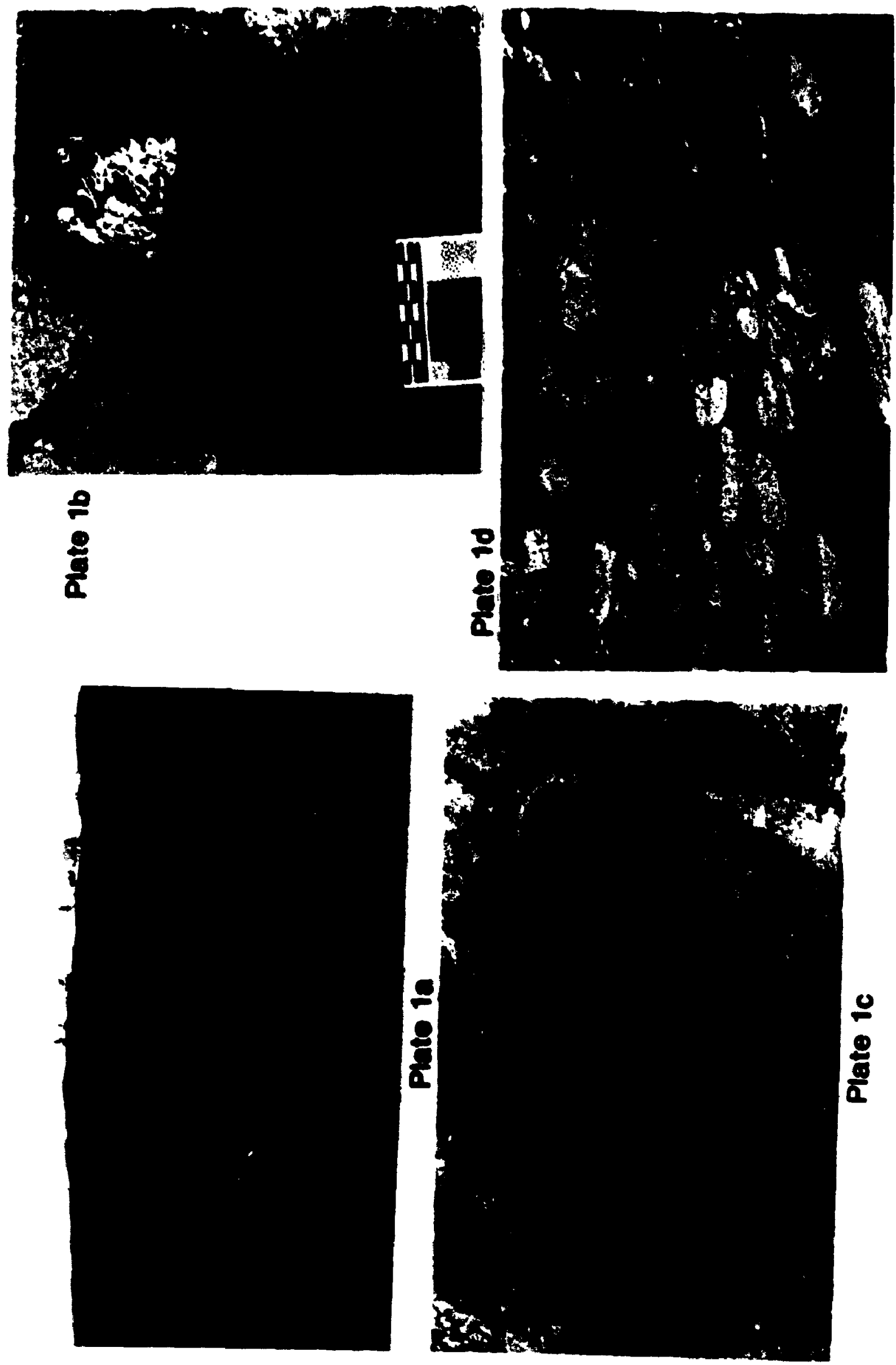


of lahar deposits and may mark the beginning of transition to Banting Group volcaniem.

Resting on the Bode member is a distinctive pillow flow unit (D), informally termed the *5 flow, containing many features euggeettve of lavas more fluid than the Yellorex Flows. The pillow rime are thinner, and vealcles are abundant along pillow selvages (Plate 2a). Repeated vesicular crusts form long drainage shelves representing sequential lava drainage and chilling (Plate 2b). Succeastve nows af slightly lower lovels permitted numerous thin crust to form within the leve tubes. Narrow irregular dykes cutting the pillows may represent magma squeezed out of lower pillows and that acted as local feeders to higher pillows (Padgham, 1987c).

An excellent example of a large feeder tube is preserved in this flow. This tube exhibits abundant branching pillows and the tube can be traced back to a feeder dyke (Plate 2c). The top and southern end of this flow is coarse-grained and resembles the dykes and sills of the Giant Section. This part of the flow is largely massive with no features other than pillow rims. It may be a large feeder tube to pillows south of the Glant Section.

Locally, the basal unit of this complex flow unit is a well-developed pillow breccia with abundant hyaloclastite. Other pillow breccias are in the southern Giant Section at this horizon, some with quartz-rich sandstone surrounded by breccia and pillow breccia fragments (E)(Plate 3a). The breccia consists of angular fragments spalled from the outer crusts of pillows. These distinctive features suggest that the \#5 flow complex is different from the typical Kam-type flow, more closely recembling flows of the Banting Group and the Duck Formation (Padgham, 1987c).

On top of the $\# 5$ complex fiow is a light grey tuffaceous sandstone $(F)$ that weathers whitish with a pinkish cast, possibly as a result of contact metamornhism due to the 8 metre-thick overlying gabbro sill (G) that has a chilled margin agalnst the sandstone. The gabbro displays subequant mafic phenocrysts up to 5 millimetres in diameter which were originally pyroxene, but are now amphibole (Plate 3b). The 
Plate 2. 


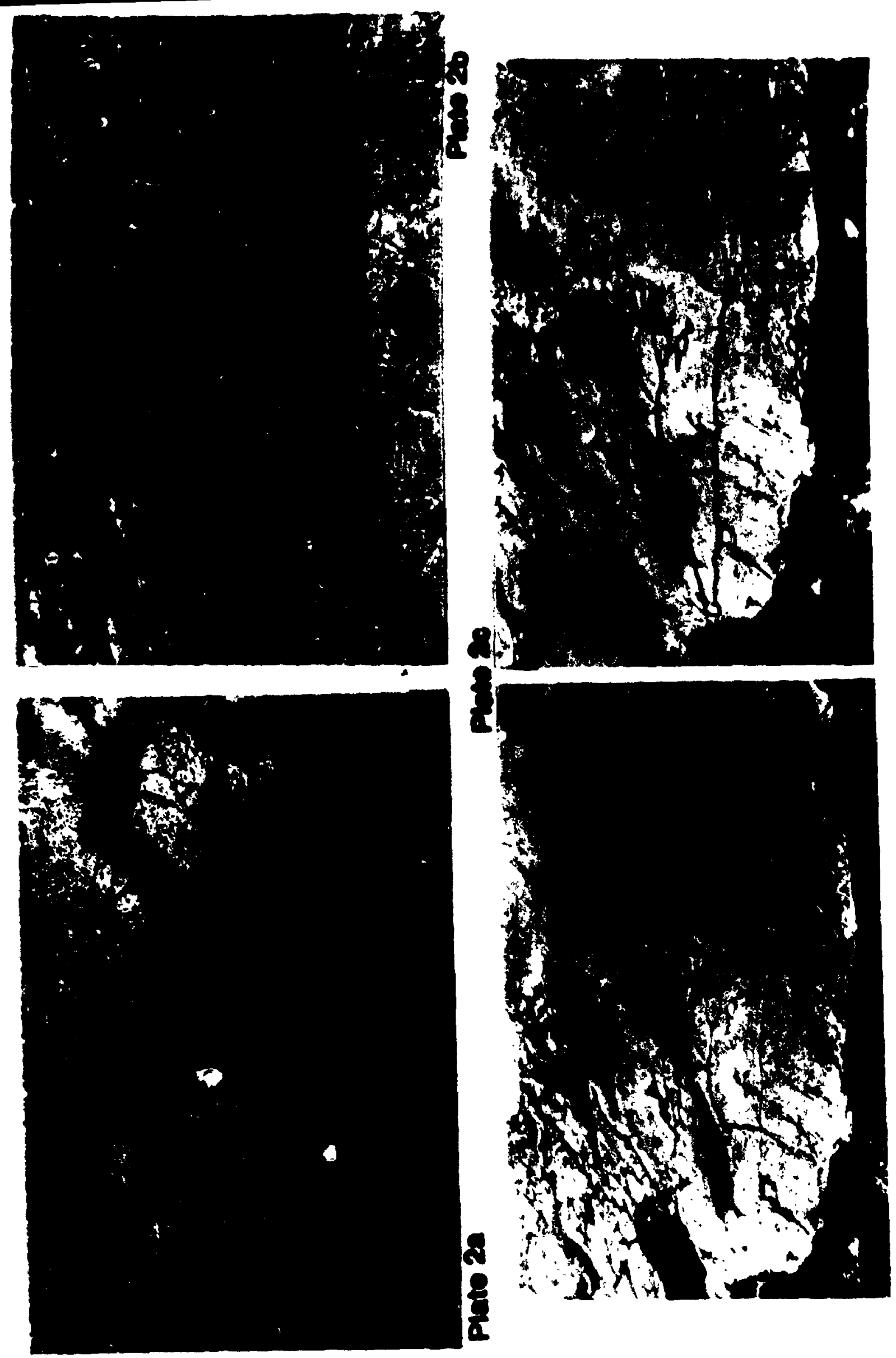


groundmass consiste mostly of altered plagloclase. Central portions of the sill contain relatively coarse clots of amphibole which ine upwards and downwards away from the centre. The top of the gabbro is chilled against an overlying tuffaceous sandstone, which has also been baked on top by another gabbrce sill. The second sill $(H)$ has a predominantly coarse core, but it grades through filie and coarse phases several times, implying multiple magma pulses during emplacement (Plate 3c). The sill grades upward into an amygdaloidal massive flow where the contact zone is marked by a string of epidote pods up to 10 centimetres in diameter (I). The irregular top of the massive flow is covered by pillow breccia $(\mathrm{J})$.

A sandstone (K) overlies the breccla, and also encloses some of the breccia fragments. Isolated pillows in the breccia contain inclusions of sandstone. Some are angular sandstone fragments, which may have originated as overridden sand, whereas in others, the sandstone forms rounded sand inclusions which may have been injected as the lava chilled (Plate 3d). The coarse sandstone is well bedded and overlain by pillows which locally depress the bedding, demonstrating that the sandstone was not lithified at the time of lava extrusion. In places, the sand occupies interpillow spaces. Laminations within the sediment show that the sand was injected upwards between the pillows (Plate 4a).

Pods of sand at a common horizon in the pillow flow $(L)$ demonstrate that sand transportation and deposition was contemporaneous with pillow formation. Above this horizon, pillow interstices are filled with sandstone, and some pillows "float" in the sediment. Cross-bedding in a number of these interpillow enclaves indicates that the sandstone was deposited by a strong current. Preservation of pillow rims suggests rapid deposition, but the absence of pillow breccia is unusual. The currents that deposited the sand during waning flow conditions might have swept the breccia away when the currents were at peak strength, or breccia simply may not have formed (Padgham, 1980).

Towards the top of the pillowed flow (M), elongate and complexly budded pillows 
Introduction to the Giant Section

51

Plate 3. 


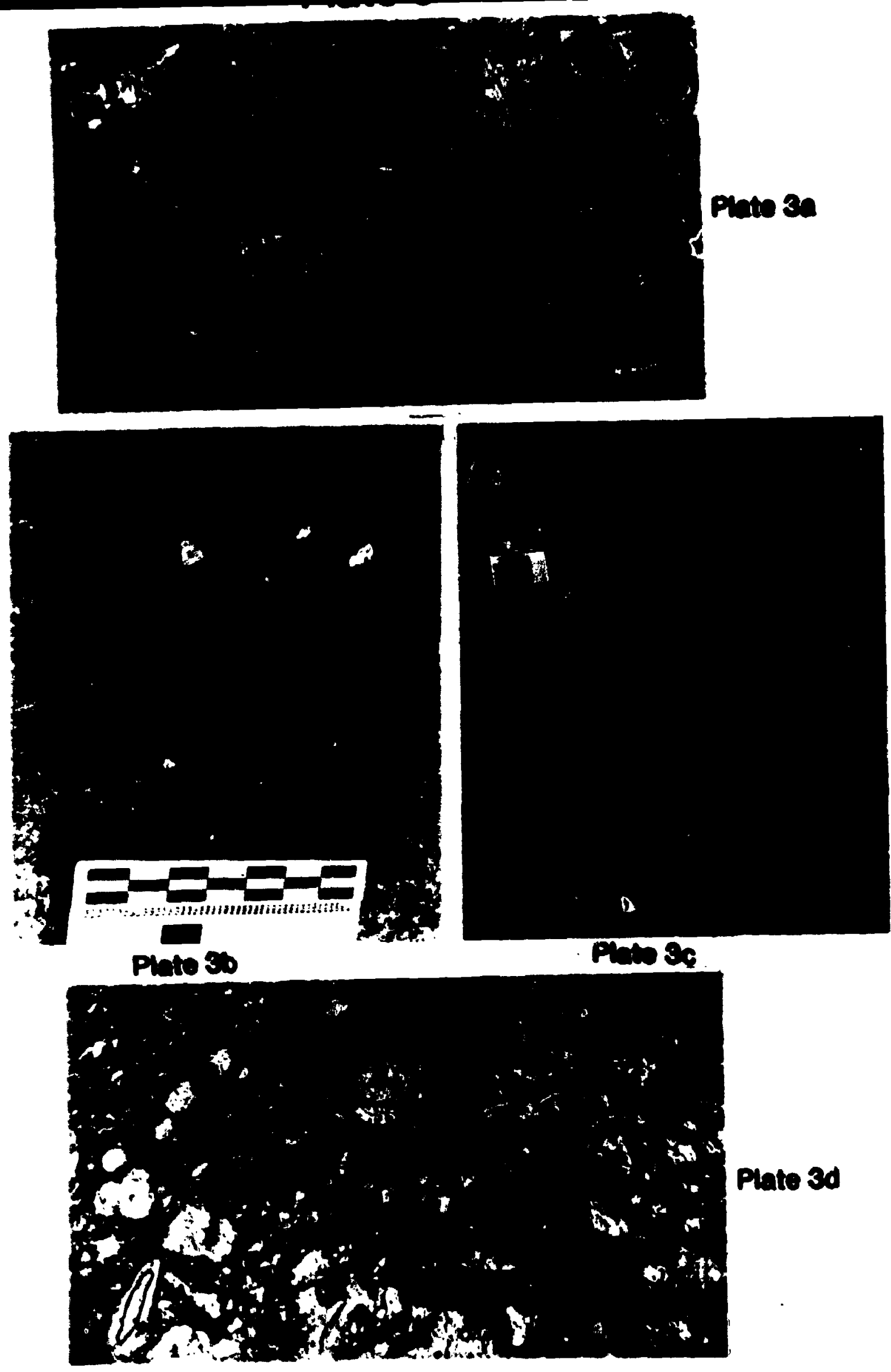


reach 4 and 5 metres in length. Many buds have incomplete selvages partially closing them off from the main pillow body. The pillowed flow is cut by six large sandetone dykes, some of which coalesce with a sandetone bed overlying the pillow fiow; all of the dykes wedge out belore reaching the lower sandstone. At the top of the flow, sandatone fills the interstices, and quartz-rich greywacke rests conformably on the flow.

The upper sandstone is the first bed in a thick sequence of coarse-grained sandstone interlayered with irregular coarse-grained gabbros (N) resembling sills lower in the Section. The gabbro sills locally crosscut the sand bedding, apophyses of chilled gabbro extend into the sand, and chilled margins completely surround the sills. Hyaloclastic breccia, as would be expected of extrusive bodies, is absent. This zone is therefore interpreted as a near-surface intrusion into wet sands intercalated with the pillowed flows. Sill intrusion probably mobilized sediments into small clastic dykes that cut the base of the sills (Plate 4b). Younger sills tend to develop above older ones because penetration of soft sediments is easier than penetration of sediments compacted by older sills (Einsele, 1985). The sandstone is overlain by graded beds of fine-grainet sandstone and cherty tuff. These beds have been intruded by a large gabbro dyke (O) which fed a network of smaller dykes and sills (Plate 4b).

The easternmost limit of the main outcrop is composed of sandstone lenses interdigitated with gabbro. Beyond the break in outcrop, all rocks belong to the Ingraham Formation of the Banting Group. The graded sandstone beds appear to mark the transition from extrusion of pillow basalts of the Kam Group to dominantly felsic pyroclastic volcanism of the Banting Group. Banting Group rocks were also encountered in a series of holes drilled across the Kam-Banting transition underneath Yellowknife Bay. Establishing the Kam-Banting contact at this level is contrary to most previous stratigraphic interpretations, but does correspond to Jollife's mapping (1942; 1946).

The Banting rocks exposed at the Giant Section start with a massivs tuff $(P)$ which grades into laminated siltstone (Plate 4 d). The tuff is crosscut by a vein network of fine 
Introduction to the Giant Section

54

Plate 4. 
Plate 4
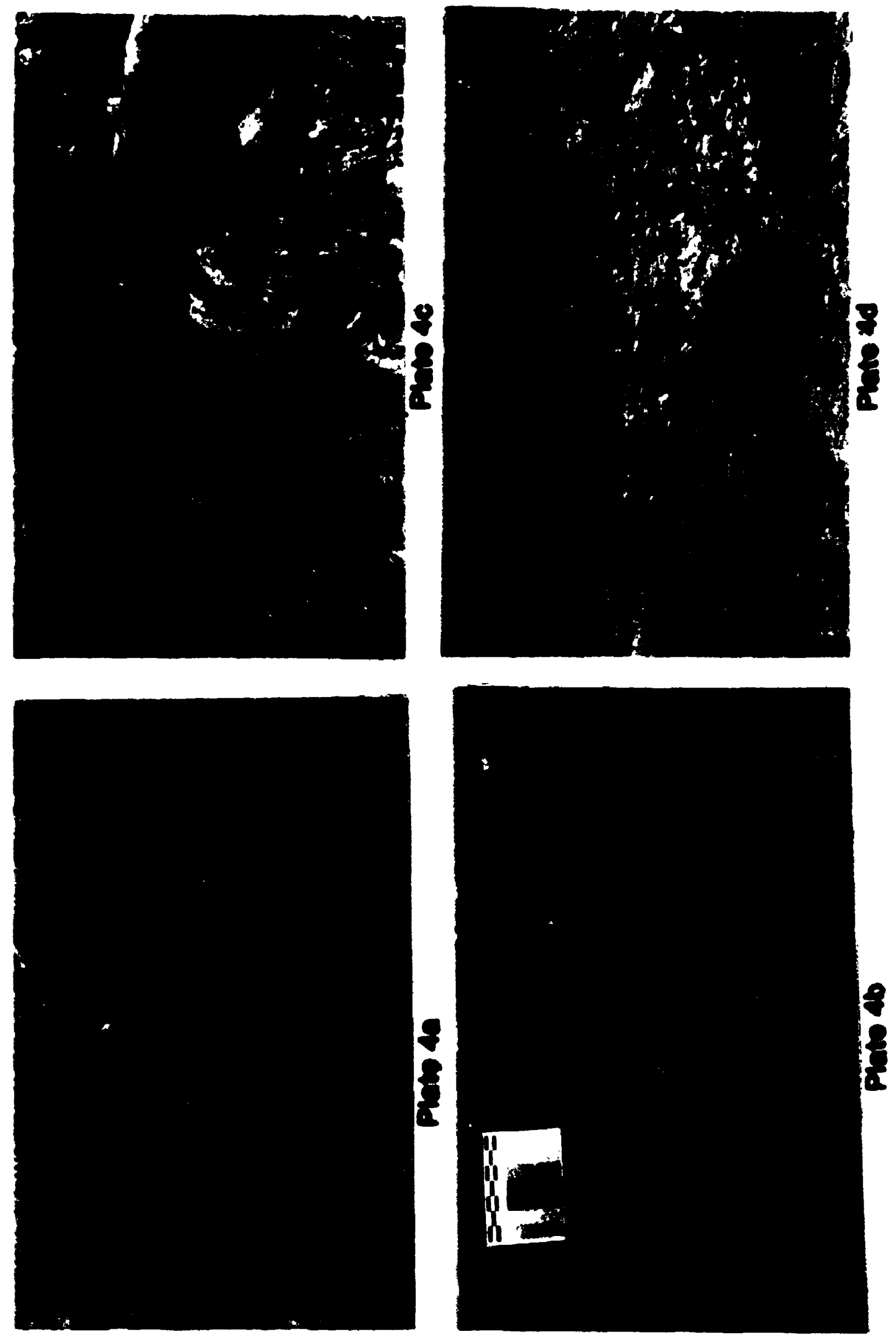
grey-tan alteration. The ash probably tused immediately after deposition, and cold water crackled the glassy ash, allowing water to seep along the newly formed fractures. The water was heated and magnesium was introduced along the fractures while silica was removed. The silica was redeposited as thin chert beds when the heated water mixed with cooler sea water.

Overlying the locally fine-grained cherty and locally hematite-rich layers is an air fall tuff zone (Q) containing tragments of lapilli size and larger. Intruding the tuff is a massive sill (R), fed by a multiple dyke similar to those in the upper Kam Group. The upper margin of the sill is vesicular but without a breccia cover. Above the sill, the tuff contains large pumice fragments that weather preferentially due to their substantial calcite content.

The next unit is composed of lavas in the form of "mattress" pillowed andesites (S) with concentric banding. The pillows are fine-grained with grey-green layers at intervals of 2 to 5 centimetres. The concentric layering may have formed as cooling contraction tractures, or by shear between congealed lava and more mobile hotter fluids in the pillow cores. As the layering is incomplete towards the bottom of the flow, shearing is a more plausible explanation. In the lowest part of the flow, pillows appear to be absent, but the layering is well developed in what is either a massive flow or a very large pillow. The interstices between the pillows contain numerous angular fragments of spalled pillow rim. Over all, this pillowed flow is easily differentiated from the typical Kam pillow flow (Padgham, 1987c).

In close association with the pillow flow is a welded ash tuff identified as an ignimbrite (T). The ignimbrite is light coloured with greenish to yellow fiamme-like lenses (Plate 5a). Thin sections of the welded tuff show that the yellowish fiamme consist mostly of felted sericite in a groundmass of fine-grained sericite, carbonate and small grains of feldspar. Broken high-quartz crystals, $2.5 \mathrm{~mm}$ in diameter, and rare, highly altered feldspar crystals form nearly $20 \%$ of the groundmass (Padgham, 1980).

The ignimbrite has been interpreted as a subaerial deposit, but the under-and 
overtying pillow flows suggest a subaqueous origin (Padgham, 1987c). The distinction between subaerial and subrqueous depoits is not always easy, because evidence is commonly indirect. Primary structures and structure sequences are not valid criteria, and conclusions are often based on the presence of pillow in the sequence. The most diagnostic feature of subserial thows was thought to be flattened, welded vesicular fragments, but under higher water pressures, wolding is possible at lower temperatures. Subaqueous debris flows are finer grained and have a higher percentage of matrix than subaerial counterparts. The bed thickness of subaqueous debris flows is commonly 3-10 times greater than the maximum fragment size, whereas in subaerial deposits, bed thickness is only 2-4 times greater (Wright et al., 1980; Fisher, 1984; Lajoie, 1984).

The felsic ash beds of the Banting Group may have been fed by felsic dykes that cut the mafic flows of the Kam Group (Plate 5b). These dykes (U) have irregular margins. commonly are less than one metre-wide, and have silicified the enclosing mafic rocks.

The entire sequence of tholeitic and felsic volcanics is cut by a large set of metagabbro dykes and sills (Plate 4C). At the northern edge of the sandstone-sill complex is a 10 to 50 metre-wide irregular sheeted metagabbro dyke. Based on their positions and lithologies, these dykes have been proposed as feeder dykes to the volcanic edifice (Padgham, 1987c; Padgham, 1980; Henderson \& Brown, 1966). The dykes, which can be traced for over $\mathbf{2 0 0}$ metres, display a variety of features suggesting intrusion into rocks and sediments that were not far below the ocean floor. These include an abundance of vesicles and selvage-like margins with associated perlitic fractures, similar to selvages around nearby pillows which were clearly formed subaqueously (Plate $5 c$ and $5 d$ ). There is a common assumption that most dykes in a volcanic system are feeder dykes or dykes that reach the surface to form nows, but observations have not supported such assumptions. Of more than 21,000 dykes in the Columbia Plateau, only a few are connected to the basalt flows (ct. Gudmundsson, 1984). Thus, the Giant Section, where there is a clear relationship between dykes, hows and sills, is unusual. 
Introduction to the Giant Section

58

Plate 5. 


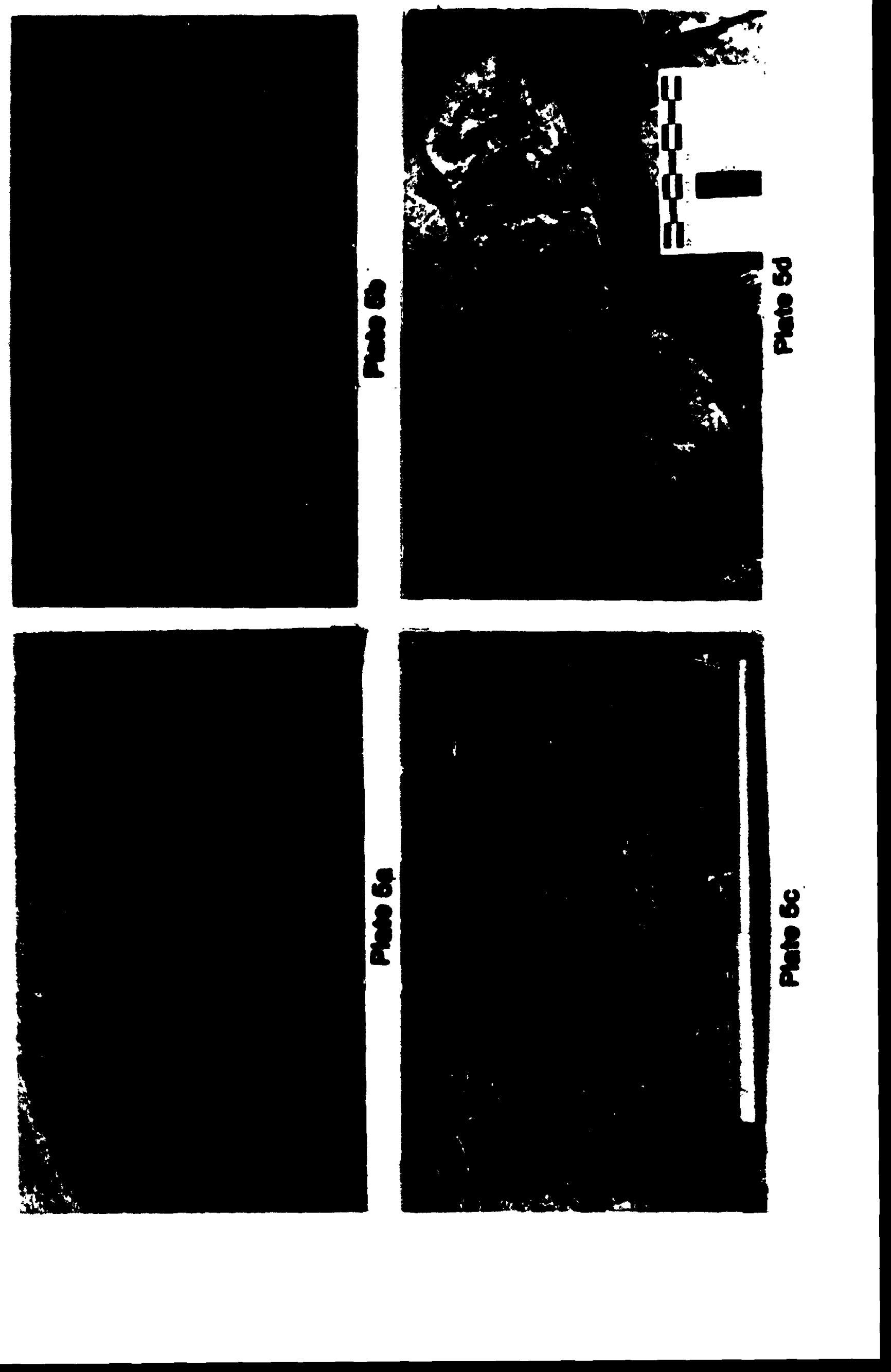


Sheeted dykes cut the Yellowknife Bay Formation to the north and south of the Giant Section, and many of these intrualons $M$ have multiple internal chills representing separate magma pulses. Studies of modern and Tertiary volcanic terranes have shown that dykes follow the path of least resistance. In a still-cooling volcanic pile, this path is often the central parts of thick lava flowe which have not completely solidified, or in the case of the Giant Section, through unlithified sediments. In more solidified flows, the path of least resistance is along sub-vertical cooling foints. Pulses of magma can repeatedly split pre-existing intrusions to produce multiple dykes (Gudmundsson, 1984).

The Jackson Lake Formation crops out north of the large multiple dyke. The Kam Group-Jackson Lake contact can be examined at only a few locations, of which the Glant Section is the best (Plate 6b). At this controversial contact in the Giant Section, the Jackson Lake Formation $(M)$ appears to lie beneath deposits identified as part of the Banting Group. This relationship led to speculation that the Jackson Lake Formation may be stratigraphically older than the Banting Group (Henderson, 1985).

The Jackson Lake Formation consists of polymictic conglomerate, containing a predominance of dark volcanic clasts and an abundance of pinkish granitic clasts (Plate 6a). Greyish to black granitoid clasts with a porphyritic aspect are also common in the matrix of quartz-rich coarse-grained sandstone. These were probably eroded from the upper portions of sub-volcanic intrusions of the Western Granodiorite (D. Atkinson, 1989, personal communication). The cobbles are distinctly flattened, and two cleavages are discernible.

Below the conglomerate is a thin zone of sandstone which lies on partially disintegrated pillows, interpreted as a regolith $(X)$. In places, the rock is highly altered and silicified, due to deep weathering along fault zones. Elsewhere, the conglomerate lies directly on pillows which are only moderately weathered. Gabbroic dykes continue from the Kam Group into the Banting Group, but where the Jackson Lake Formation is clearly identified, the dykes are truncated by the erosional unconformity. As the Jackson Lake Formation rests unconformably on the eroded Upper Kam Group and the Banting 
Plate 6. 
Pros

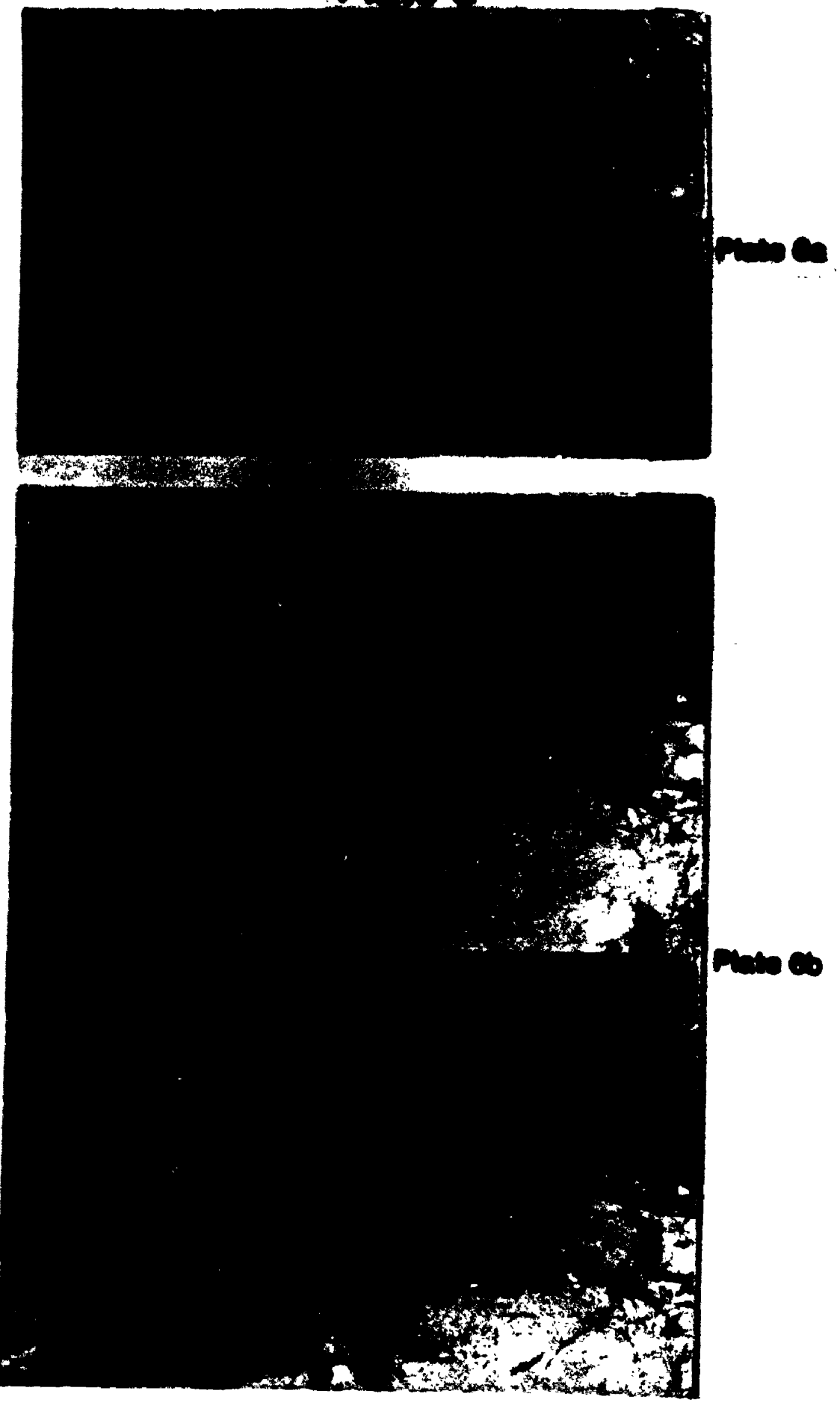


rests conformably on the Kam, faults have been hypothesised to account for the dislocation seen at the Glant Section. A faut $M$ in the covered zone is suggested by shearing of the Jackson Lake Formation and abundant quartz veinlets (Padgham, 1987c).

Possibly the youngest rock in the Giant Section is a thin fine-grained mafic oyke rich in epidote and pyrite that cuts parallel to the shoreline through the Banting outcrop (Z). The diabasic nature of this dyke is distinct from other mafic intrusions of the area, and distinguishes it as a young dyke, possibly even Proterozoic in age (Padgham, 1987c).

The Giant Section is not necessarily representative of the entire Yellowknife Belt, but it does provide an opportunity to study low grade metamorphism of the Upper Yellowknife Bay Formation. Shortly after the basalt was emplaced and the pillows formed, sulphide minerals were removed from the pillows through exchange with seawater. Sulphur and trace metals ( $\mathrm{Sn}, \mathrm{Pb}, \mathrm{Cu}, \mathrm{Zn}, \mathrm{Ca}$, and $\mathrm{Ni}$ ) were concentrated in the rims of pillows. Diagenetic alteration also led to the development of palagonite, zeolites and carbonates, with an accompanying enrichment of water, potassium and some iron and manganese. Much of the alteration apparently focused on fractures that extend in from surface of the pillows. Baragar et al. (1979) suggested that spilitization occurred in an essentially closed system, without much exchange with seawater. Most of the Giant Section has been metamorphosed to greenschist facies, but parts approach the amphibolite boundary (Boyle, 1961). Temperature estimates of $480^{\circ}-530^{\circ} \mathrm{C}$ and pressures between $200-300 \mathrm{kPa}$ have been proposed for peak metamorphic conditions (Baragar et al., 1979).

The distribution of metamorphic minerals in pillows at the Giant Section probably reflects primary zonation of the pillows. Chlorite and epidote predominate at the rim; feldspars are concentrated in the margin of the crystalline interior. The bulk of the crystalline interior consists of a rather uniform intergrowth of actinolite, epidote, chlorite, albite, sphene, quartz and calcite. Epidote is enriched in iron at the rim, and depleted at 
the margin of the crystalline interior. Epidote has developed at the rims due to oxidation induced by palagonitization, and the residual glass has been replaced by chlorite (Baragar at al., 1979). Spherules, originally of pyroxene and plagloclase, commonly are replaced by amphibole and alblte in a matrix of chlorite replacing former glass; fine rims of sphene probably have formed from titanlum released during metamorphism of the pyroxene. Opaque minerals in the pillows tend to be pyrrhotite rather than magnetite.

Geochemical data and petrographic evidence suggest that pristine pillowed basalt underwent alteration or "spilitization" before greenschist metamorphism. The spllitic rocks probably formed by degradation of magmatic rocks with preservation of primary textures to mineral assemblages representative of low-grade (zeolite-greenschist racles) metamorphism (cf. Vallance, 1974). Secondary low-grade alteration is characteristic of environments where an abundance of hydrous fluids interacts with solid rock. This can occur on a variety of scales ranging from localized hydrothermal alteration to regional burial metamorphism (Nallance, 1974; Fiala, 1974).

Whereas the metamorphic minerals epidote and chlorite were formed as a result of burial metamorphism, others developed during regional metamorphism. Burial metamorphism caused replacement of vol-anic glass, but pillow cores and lava flows were recrystallized during regional metamorphism. The minerals in the pillow margins were then adjusted to the new pressure and temperature conditions. This differential metamorphism resulted in iron enrichinent of the pillow rims. The high carbonate content of the rims and the veinlets were the result of a high $\mathrm{CO}_{2} / \mathrm{H}_{2} \mathrm{O}$ ratio in the ambient fluid due to regional matamorphism (Baragar ot al., 1979). 


\section{The Setting and Sedimentology of the Bode Member: An Arciean Debris Flow}


Introduction

Interflow sediments in the Yellowknife Belt have long defied detailed study. The sediments are comm: --iy massive or poorly stratified, with contacts obscured by faults. More easily erodable than the enclosing volcanic rock, sedimentary exposures are poor and small. The sediments have been described as "cherty tuffs" (Boyle, 1961; Henderson \& Brown, 1966) and have undergone little further study with the exception of observations by Padgham (1980; 1987a). Previous interpretations of depositional environments were based on the enclosing volcanic rocks. Depositional models were restricted to classification of sediments as tuff or chert deposits. Insight offered by the voluminous mafic volcanic rocks towards interpreting the depositional setting is minimal and represents only short intervals of time. In contrast, the sediments accumulate during long hiatuses between events of flow extrusion, and offer an important record of volcanic belt formation.

The importance of these thin beds (commonly less than 10 meters thick) should not be underestimated. The latterly extensive nature and distinctive characteristics of sedimentary beds produce excellent markers for tracing units across numerous Proterozoic faults (Henderson \& Brown, 1966) (Figure 10). The felsic composition and intimate relationship with volcanic deposits make the sediments excellent targets for geochronological analysis (Isachsen et al., 1989). The interflow sediments contain appreciable trace amounts of gold and silver, in adcition to high carbon and sulphur concentrations, and are possibly associated with the location of ore bodies (Boyle, 1961).

The purpose of this study is to describe one sedimentary interllow bed, informally known as the "Bode Tuff" and more correctly termed the Bode member (Helmstaedt \& Padgham, 1986a). Detailed examination of this tuffaceous bed has revealed a unique insight into the development of an Archean volcano. 
Figure 10. 


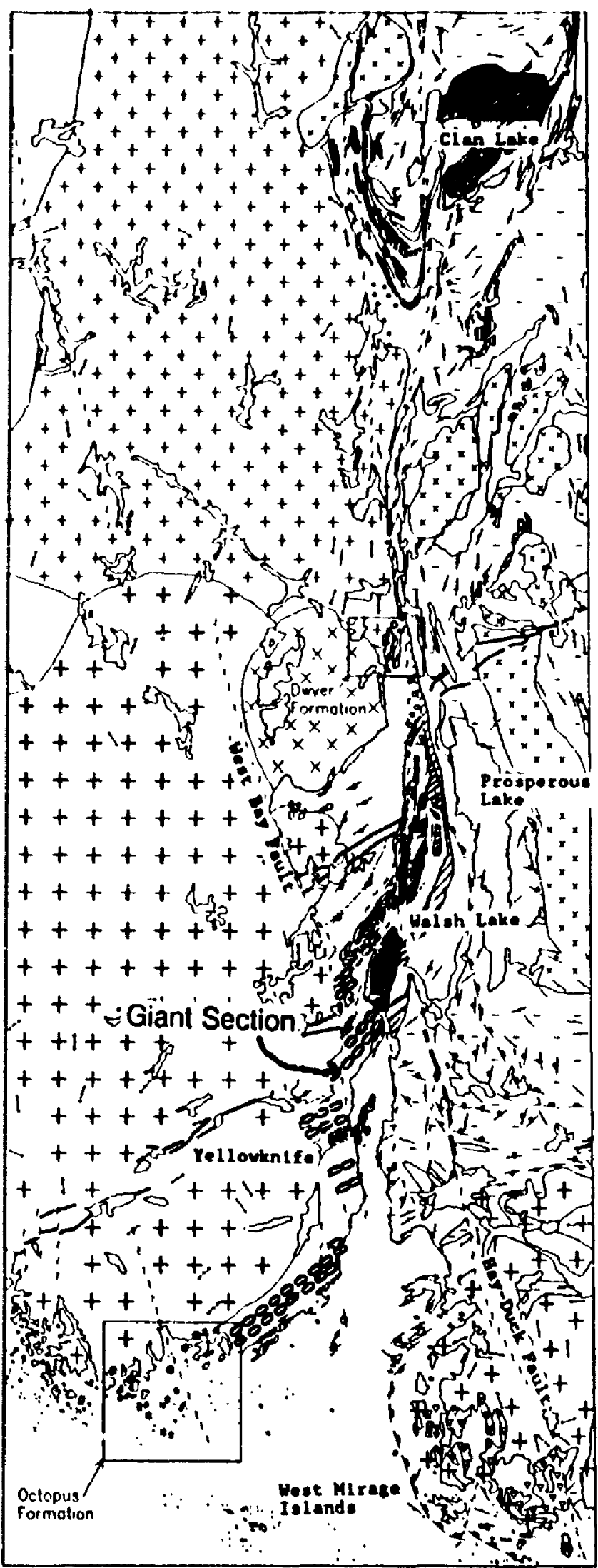

Prolerozoic

Proterozoic Dykes

Archean

E: Prosperous Lake Gronite

$x x$ Duckfish Loke Granite

[Y] Wool Bay Dionte

[t] Defeat Plutonic Complex

$[++$ Ariton Complex

[oj] Jackson Lake formation

$\therefore$ Burwosh formotion

Banting_Group

EC] Prosperous formotion

VDA Wolsh formation

Ingrahom formotion

* Octopus Formotion

Lam Croup

[IIII] Gobbro Sills

[- Yellowknile Boy Formalion

$\Rightarrow$ Townsite formation

$\square$ Crestourum Furmotion

Chan formation

Pre-Kam Group

-... Iron Formation

0000 sodmortary

mertons

Lcte Foults

Contocis

Foliotion Dip

Unknown

Inclined

Bedding Fillows Tops known

Bedding Dip Tops known

Inclined

Vertical

Overlurned

Bedding Dip Tops Unknown

Unknown

Inclined

Cordierite Isogrod

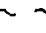


Location

The Bode member was first described by Henderson and Brown (1966) as one of four tuff bands used as marker beds in the three major fault blocks of the greenstone belt. Since the Yellowknife volcanic belt forms a steeply dipping homocline, all interflow sediments are steeply dipping, and horizontal outcrops expose cross-sections through the sediments. The unit name was derived from Martin Bode, the original settler on property immediately adjacent to one of the best exposures. The property is located on the west shore of Yellowknife Bay, east of the north end of Fault Lake (Figure 11). Striking northeast, the Bode member is displaced by the Townsite Fault and additional outcrops are near the bay shore, by the Giant Mine iownsite. The bed extends three kilometres farther northeast, where the sediments pinch out. Beyond this point, the stratigraphic horizon occupied by the Bode $m$. mber, as defined by the enclosing volcanic units, ce:n be traced another half kilometre, but the bed is not recognizable. South of the "Bode" property, the member was offset by the Ayr Fault, and is presently submerged beneath Back Bay. Beyond the Ayr Fault, the West Bay Fault offset the Bode member a further 4 kilometres to the southeast.

In the southern part of the Yellowknife volcanic belt, numerous thin interflow sediment beds are possible correlatives to the Bode member, but the poor quality of exposure has hindered positive identification. Several authors including Henderson and Brown (1966) and Helmstaedt and Padgham (1986a) have speculated on the location of the Bode member west of the West Bay Fault.

The Bode member was examined along its entire exposed length, including possible extensions west of the West Bay Fault. Eleven sections were selected for detailed study on the basis of section completeness and unequivocal identification as part of the Bode member. The outcrops were photomapped using the technique described in Donaldson et al. (1987). A strip of one-meter-squares was chalked on the rock surface perpendicular to the bedding and photrgraphed using a $35 \mathrm{~mm}$ camera and slide film. 
Setting and Sedimentology of the Bode Member

70

Figure 11. 


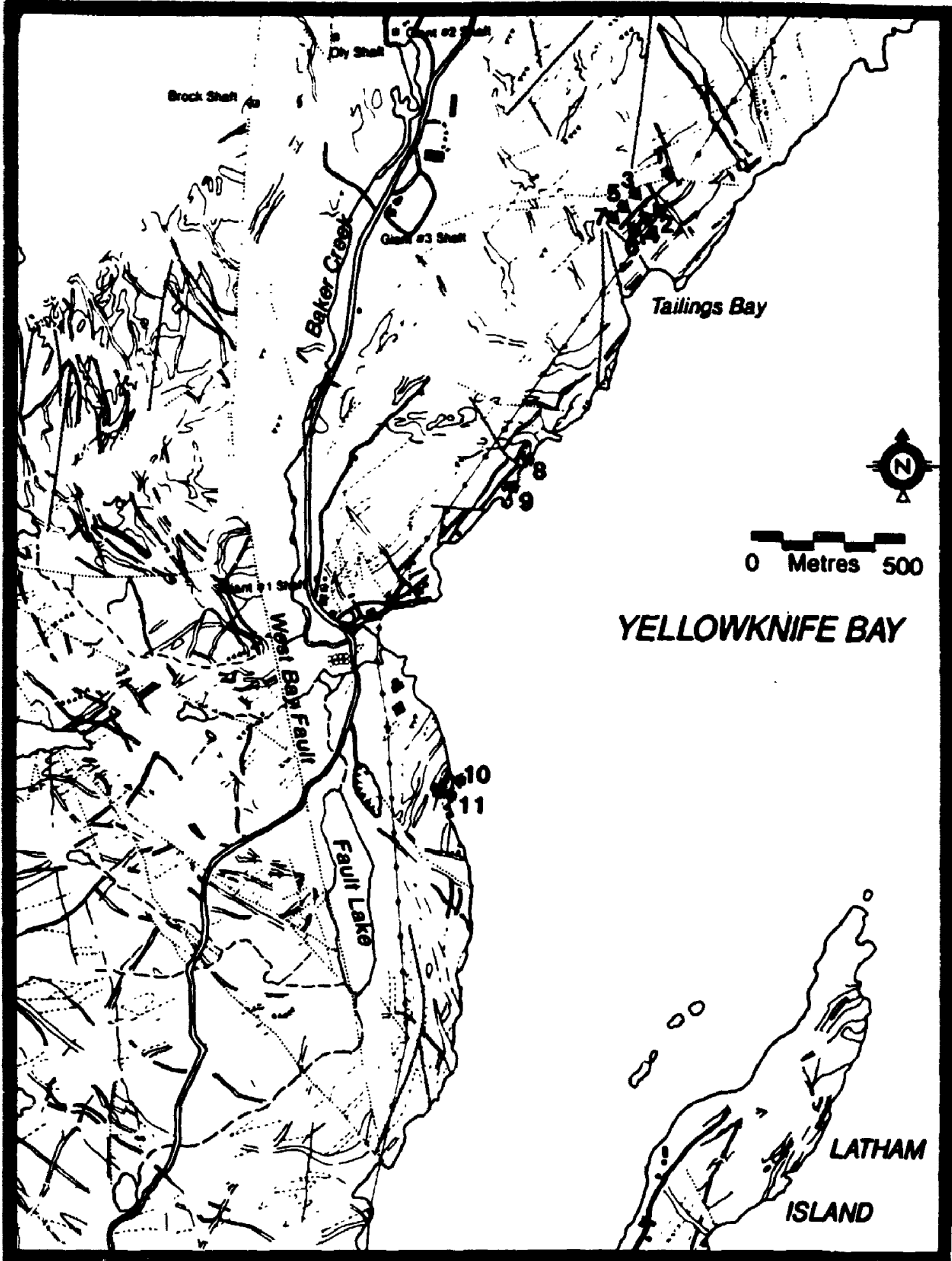


Sketches of the outcrop were prepared by projecting the transparencies onto a 10 centimetre grid and adjusting the projector for distortion. The assembly of maps was augmented by the use of field sketches, notee, hand samples and thin sections.

\section{Setting}

The Bode member is in the upper half of the Yellowknife Bay Formation, Kam Group. The dominantly tholeitic Yellowknife Bay Formation conformably overlies the felsic Townsite Formation and is overlain by the Ingraham Formation of the Banting Group (Figure 4). The lower Yellowknife Bay Formation consists of an agglomeration of massive, pillow and pillow-breccia flows of tholeitic composition. Among these flows are the distinctive variolitic Negus and Yellorex Flows. Between the flows, some of which are lenticular, are laterally extensive sedimentary beds that near the base of the Yellowknife Bay Formation are best characterized as cherts. Higher in the formation, tuffaceous sediments are more common. The sequence is capped by turbiditic sandstone and felsic pyroclastics belonging to the Ingraham formation. The entire package is intruded by a swarm of gabbro dykes fed by large gabbro sills in the Townsite Formation. The total thickness of the Yellowknife Bay Formation is not known, because deformation by faults and shears of several ages has attenuated the formation (Brown, 1989).

The Bode member rests on the Yellorex Flows. Pillows of these flows weather dark green to light brown/red and display 1 - 3 centimetre-thick brown/black pillow rims. The pillows are mostly ovoid and commonly less than two metres in cidmeter (Plate 1c). However, some pillows are exceptionally long and thin, up to several tens of metres in length and less than a metre thick (Potts, 1988). The pillows are not vesicular, but contain concentrations of varioles. The varioles range from 5 - 10 millimetres in diameter and consist of a fine-grained matte of epidote, hornblende and albite (Plate 1b). These spheres are more resistant to erosion than the groundmass and project slightly on weathered surfaces. Some pillows consist almost entirely of whitish weathering varioles 
that coalesce towards the pillow core. Uniform selvage thickness suggests that the pillows have not been substantially deformed in the horizontal plane, but in vertical sections, varioles display a 1:3 stretching ratio.

Overlying the Bode member is a complex series of basaltic flows known as the \#5 flows (Padgham, 1987c). Massive-basalt, pillows and pillow-breccia comprise the non-variolitic flows. The basal member of the flow unit, a pillow-breccia, contains irregular pillow fragments completely surrounded by thin selvages, enclosed in a matrix of hyaloclastite and sediment. Both the breccia and the overlying pillows display many features which distinguish the $\# 5$ flows from the Yellorex Flows. Pillow rims are thinner and less distinctive, with a coloration similar to the light, red/brown pillow cores. Vesicles are abundant and concentrated along selvages (Plate 2a). Repeated vesicular shelves within isolated pillows represent crusts from which the lava drained in pulses, leaving stacked tabular shelf-like crusts (Plate 2b). Basalt at the top of the \#5 flow is massive and coarse-grained, and may have been a feeder tube to flows and pillow flows farther south. The Bode member is between the two contrasting basaltic flows.

\section{Sedimentary Characteristics of the Bode Member}

The Bode member is composed essentially of conglomerate, sandstone and fine-grained ash beds. The distribution and relative proportions of these components allow the differentiation of proximal and distal deposits. The clasts of the conglomerate are the most striking features of the Bode member. Their size and heterogeneity are unique in the Yellowknife Bay Formation, and their distribution accentuates the distinction between proximal and distal deposiis.

Clasts

The smallest clasts in the Bode member are iron sulphide-rich chips, ten millimetres in length and only two millimetres thick. The clasts are dark brown and are 
Often surrounded by a $2 \mathrm{~cm}$ halo of rust-stained matrix (Plate 7a). Internal structures are not visible, even in thin section. The clasts appear to consist of finely disseminated pyrite. Although numerous, the small fragments constitute less than $5 \%$ of the conglomerate.

Far more voluminous are angular to subangular fragments of variolitic pillows constituting up to $30 \%$ of the clasts (Plate $7 \mathrm{~b}$ ). Occasional large mafic clasts display a preserved pillow margin as well as the transition zone from core to selvage. More commonly, selvage fragments have been separated from the massive-basalt of the pillow cores. Most mafic clasts are $2.3 \mathrm{~cm}$ across, but the largest are up to $30 \mathrm{~cm}$ in diameter.

A rare clast type in the Bode member are those composed of stratified sandstone (Plate 8a). Blocks $20.50 \mathrm{~cm}$ long are present in one section. Elsewhere, smaller blocks may not have been recognized because the sedimentary clasts lack sharp boundaries, and grade into the surrounding matrix. A prominent internal structure of the blocks is a well-developed parallel stratification, and the clasts are most discernable where the internal structure is at a high angle to stratification in the matrix. Equally uncommon are angular blocks of laminated fine-grained sandstone $10-20 \mathrm{~cm}$ long, with mildly undulating laminations (Plate 8b). These are truncated by sharp contacts, suggesting that the sediments were well-indurated before erosion and incorporation into the Bode member.

A fourth clast type is generally restricted to isolated fine-grained beds. Dark-brown to grey and lensoidal, the clasts have wispy terminations parallel to bedding suggestive of fiamme (Plate 8d). Although the fragments are a uniform size within a single bed, they vary from one bed to another, from $2-6 \mathrm{~cm}$ in length and $1.3 \mathrm{~cm}$ in width. Thin sections show that the fiamme-like clasts consist of masses of yellow felted sericite in a groundmass of fine-grained sericite, carbonate and small feldspar crystals.

The most distinctive clasts in the Bode member are white to light-grey-weathering 
cobbles of rhyodacite (Plate 7c). Most are well-rounded and $2-10 \mathrm{~cm}$ in diameter. The clasts are mainly massive and internally structureless, composed of a fine-grained matte of sericite containing quartz eyes and randomly oriented plagioclase crystals up to one millimetre in diameter. Important to understanding the Bode member are well-formod zircon crystals which have been used for radiometric dating (Isachsen et al., 1989).

Some felsic clasts are rounded with one or two flat faces, suggesting the breakup of a rounded clast; others show subtle discoloration rims, slightly more pinkish than the body of the clast. In a few examples, the hematized rim is truncated, with unaltered core directly contacting the surrounding matrix. Although most of the rhyodacite clasio are massive, a few are composed of $5-10 \mathrm{~mm}$ subangular fragments cemented in a fine siliceous matrix (Plate 7d).

Proximal Deposits

Proximal deposits are characterized by one or two cycles of coarse-tail graded basal conglomerate grading into a massive sandy ash, where the matrix supports well-rounded rhyodacite boulders (Figure 12 and Figure 13). In such proximal sections, the Bode member rests on an erosional unconformity with variolitic pillows (Plate 9a). The unconformity has a maximum relief of two meters, largely controlled by the pillow forms. In places, pillows are fractured and only the lower halves are in situ (Plate 9b). Hyaloclastite is not present at the contact, in spite of being common in pillow interstices throughout the underlying flow (Plate 1b). Pillow selvages, normally 3 centimetres-thick, are thinner, broken or missing at the unconformity.

Resting on the erosional contact is a clast-supported coarse-pebble conglomerate. The massive basal units consist mostly of angular to subangular fragments, $2-20 \mathrm{~cm}$ in diameter, with isolated larger blocks. Rhyodacite clasts constitute over $50 \%$ of the clasts, but angular variolitic pillow fragments tend to be larger. Sulphide-rich clasts are uniformly distributed throughout the basal unit (Plate 9a). The difterent clasts form an intact 
Plate 7. 


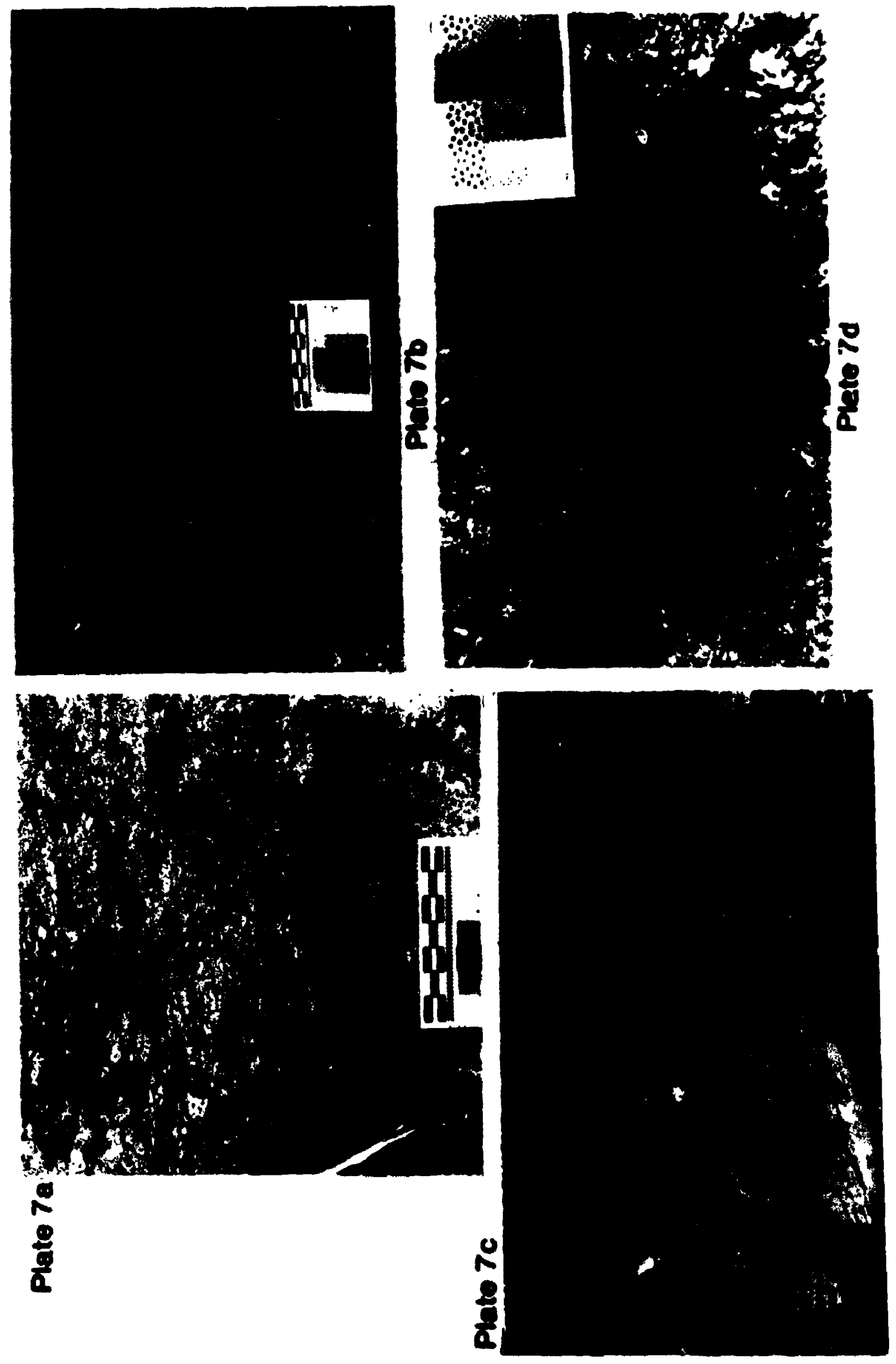


Plate 8. 


\section{Plate 8}
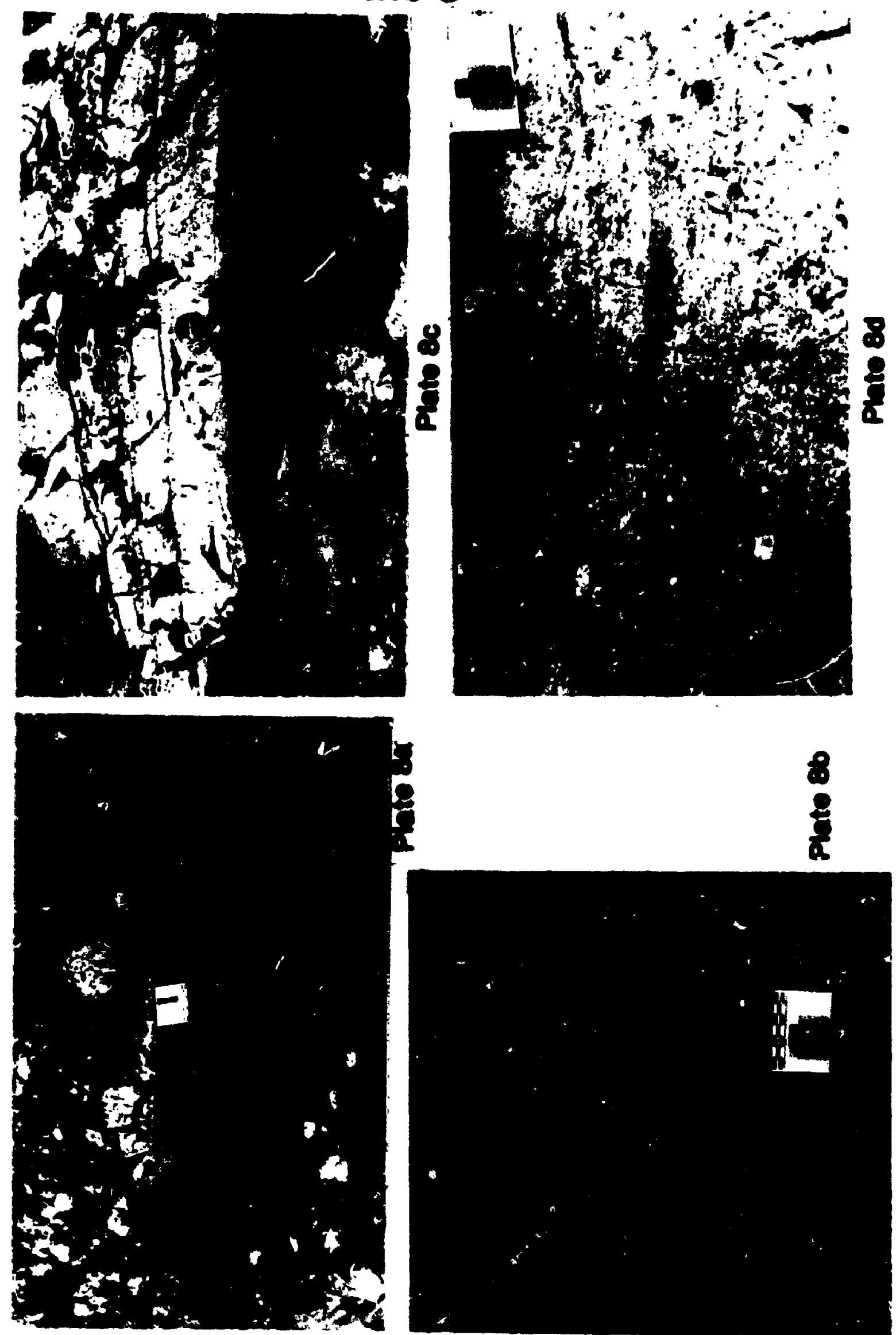
(iv) pumice lapilll that float to the surface (Sigurdsson, 1982).

Variations in typical volcanic rock facies reflect distance to source. Dykes, sills, plutons and lava flows all occur near or at the source, as do coarse-grained pyroclastlc rocks. Subaqueous lahars are further sorted during movement and have characteristic vertical and lateral facies changes. However, deposits of pyroclastic flows within a few kilometres of the eruption centre are poorly documented. Generally, framework particles progressively decrease in size away from source, although the finer constituents forming the matrix do not show a progressive decrease. Farther from the volcanic source, associated lava hlows and intrusive rocks are less common, and the volcaniclastic sediments become finer grained. The proximal deposits are most strongly influenced by the eruption mode and history, whereas the distal facies are more affected by settling velocities and ocean currents. Distal subaqueous lahars interbedded with marine sediments closely resemble turbidite sequences. Fall-out tuffs commonly are interbedded with both proximal and distal facies. This depositional model is well suited to the Bode member (ct. Yamada, 1984; Fisher, 1982; 1984; Lajoie, 1984).

\section{Clasts}

Lithic clasts in the Bode member can be classified into three groups: cognate clasts, accessory clasts and accidental particles. Cognate clasts include abundant hyaloclastic lapilli and pumice fragments. The hyaloclastic lapilli and pumice fragments are glassy products of hot lava quenched in water, and are good indicators of vesiculating magma erupted underwater. The depositional manner of the two cognate clast types was however, different. Low-density pumice fragments may have been erupted subaerially and aerodynamically sorted before sinking. Thus, isolated pumice-rich beds represent fall-out beds deposited atter clast formation and eruption (Yamada, 1984; Sigurdsson, 1982). In contrast, the ubiquitous distribution of rusty-brown hyaloclastic fragments suggests an origin intimately related to bed formation. The 
Setting and Sedimentology of the Bode Member

80

Figure 12. 


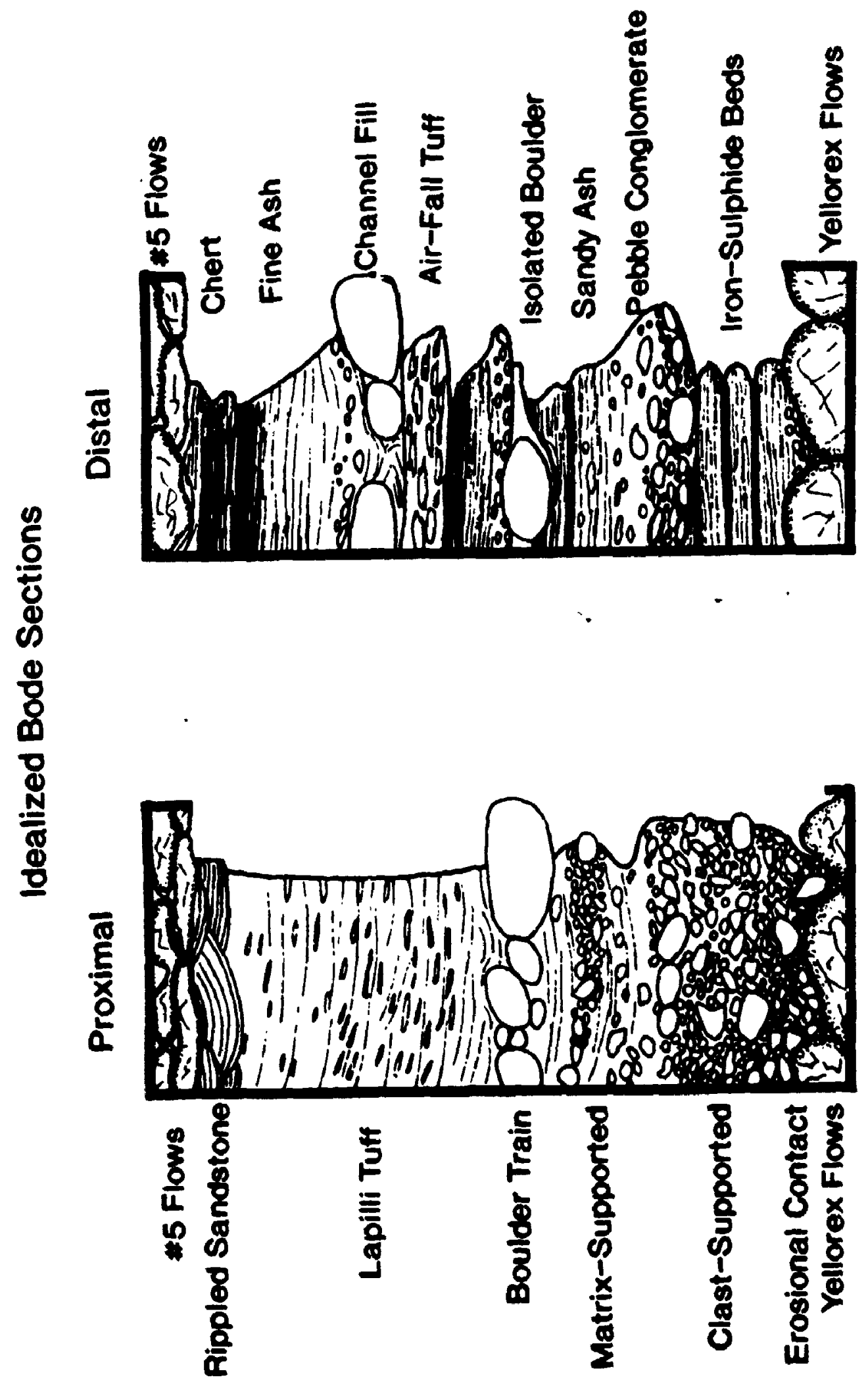


Figure 13. 


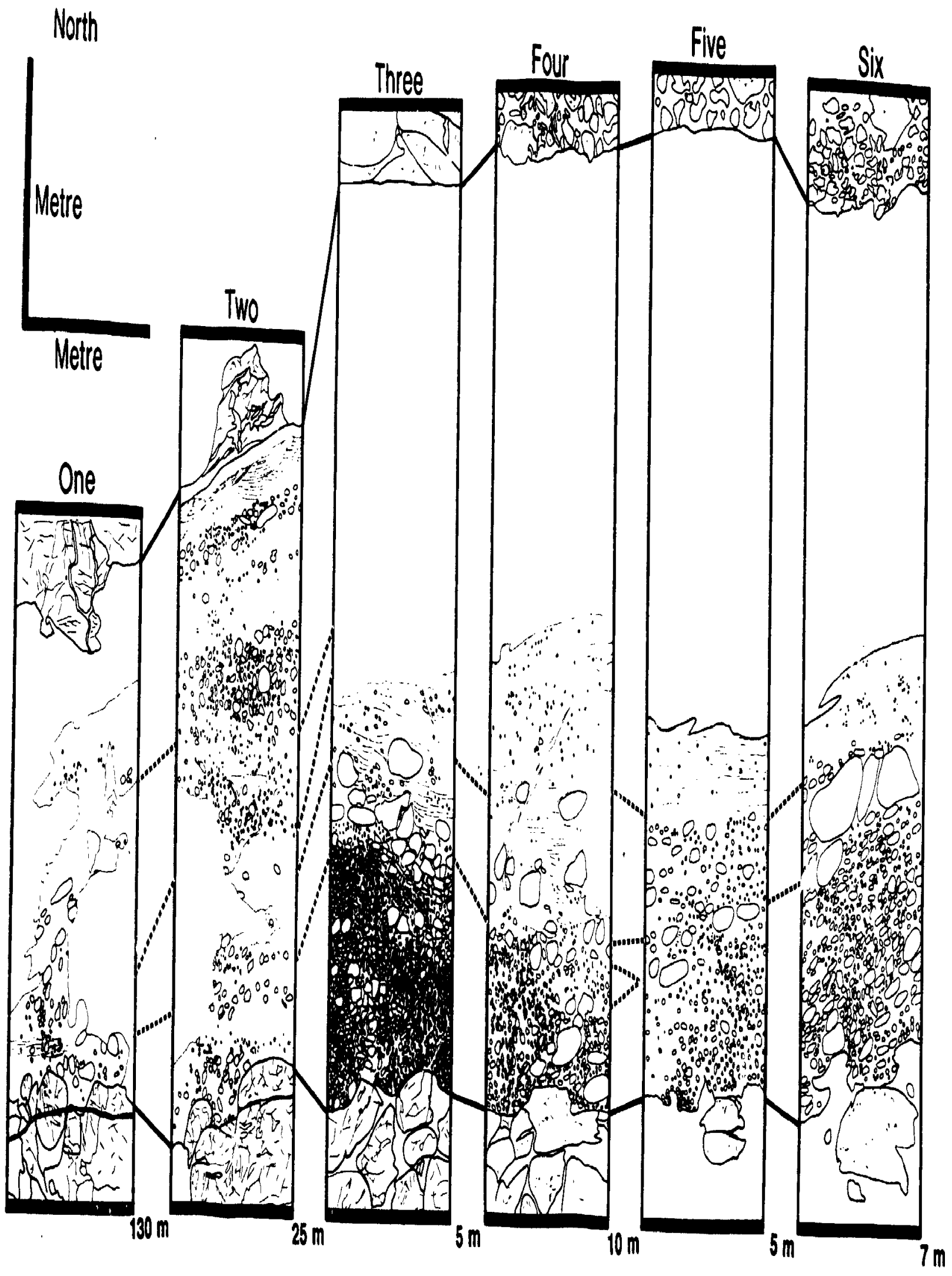


Five

Four

consongen

\section{Six}




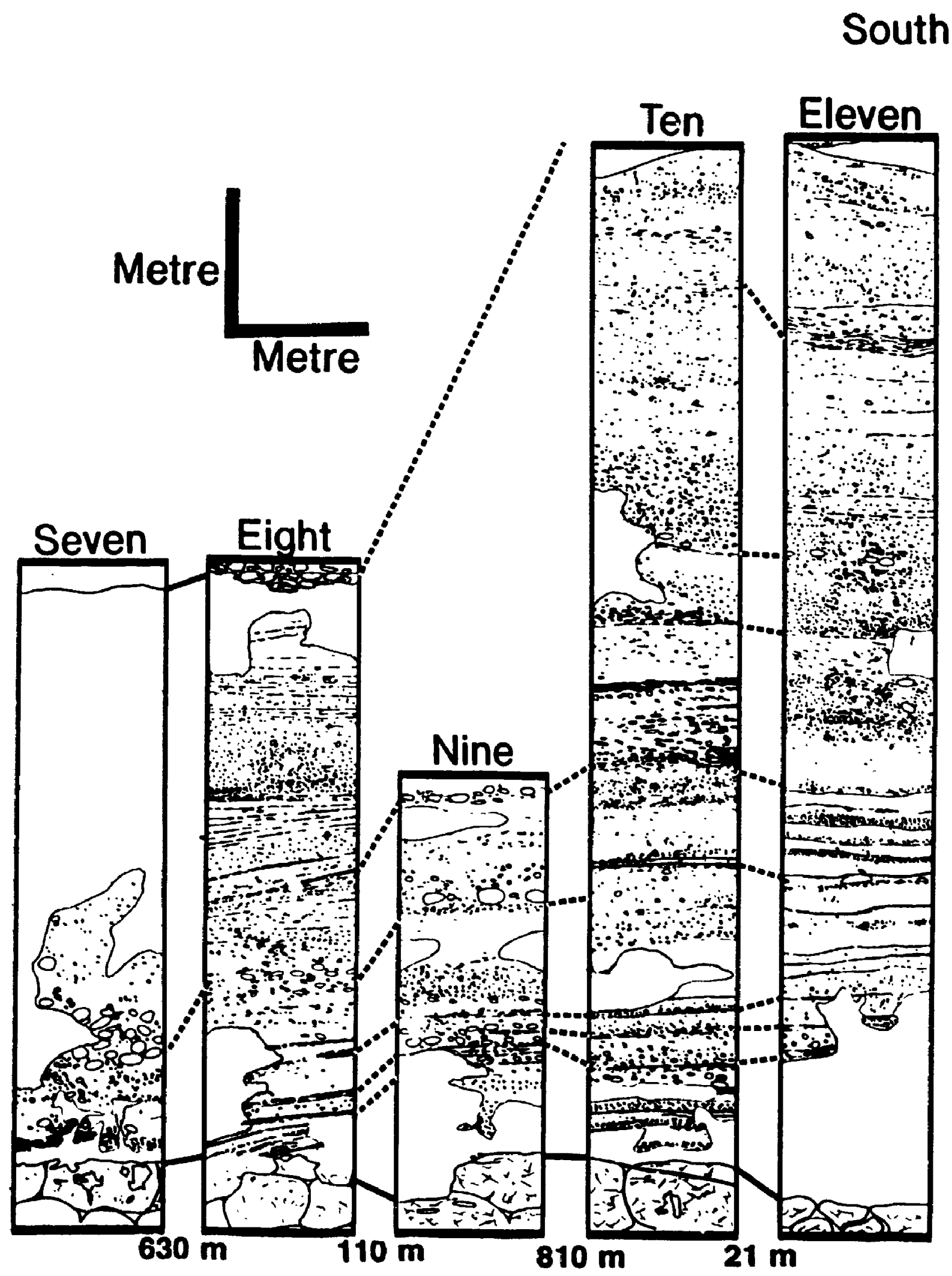


Setting and Sedimentology of the Bode Member

84

Plate 9. 

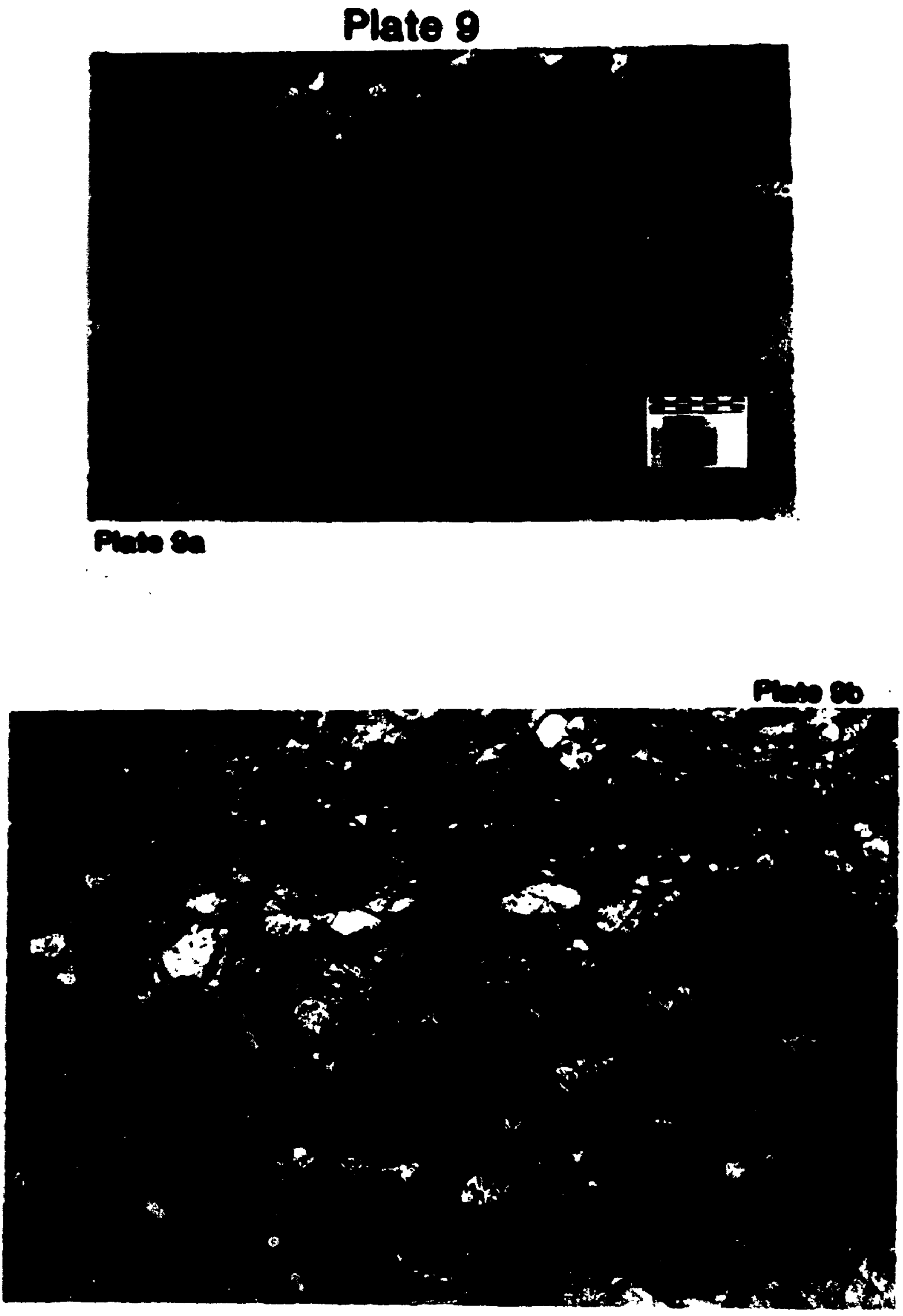
framework with interstitial sand-eized matrix conettuting $10-25 \%$ of the rock. The tuffaceous matrix consisting of ine-grained hyaloclaetlc fragments, quartz cystals and coarse sand-sized fragments of felsic rock, la cemented by silica. A former glass component of the matrix has been altered to serictte and epidote. All remaining voids are filled with carbonate.

The basal conglomerate is massive, and grading within the unit is not recognized. The fabric is isotroplc, but elongate partictes are commonly oriented roughly parallel to the depositional surface. Crude divisions defined by small changes in lithic content result in localized lithic-rich and matrix-rich bands. These zones are not size-graded, but show both vertical and lateral density grading. Poorly developed cross-bedding can be seen in matrix concentrations on the lee side of larger clasts.

The basal conglomerate thickness does not exceed two metres in the Bode member, and even this may be an amalgamation of two or more erosion and depositional cycles. Locally, poorly defined surfaces parallel the depositional surface within the conglomerate. Laterally, the basal conglomerate grades into a matrix-supported conglomerate over the distance of a kilometre (Figure 13). The number and thickness of clast-poor bands increases until matrix forms a substantial proportion of the unit. Vertically, similar grading from the basal conglomerate to a matrix-supported conglomerate takes place over only $\mathbf{2 0}$ centimetres of section (Plate 10a).

Overlying the clast supported conglomerate is the second bed-type in the Bode member, a matrix-supported conglomerate. Sulphide clasts are absent and rhyodacite clasts are not as abundant as in the basal conglomerates, but the number and size of variolitic pillow fragments is consistent throughout both bed-types. The matrix is composed of fine sand-sized hyaloclastite, broken quartz crystals and coarse sand-sized felsic rock fragments. Additionally, $20 \%$ of the matrix is coarse sand- to pebble-sized hyaloclastic fragments, which are not common in the basal conglomerate. The rusty brown fragments are primarily epidote and sericite and an initial glassy composition is 


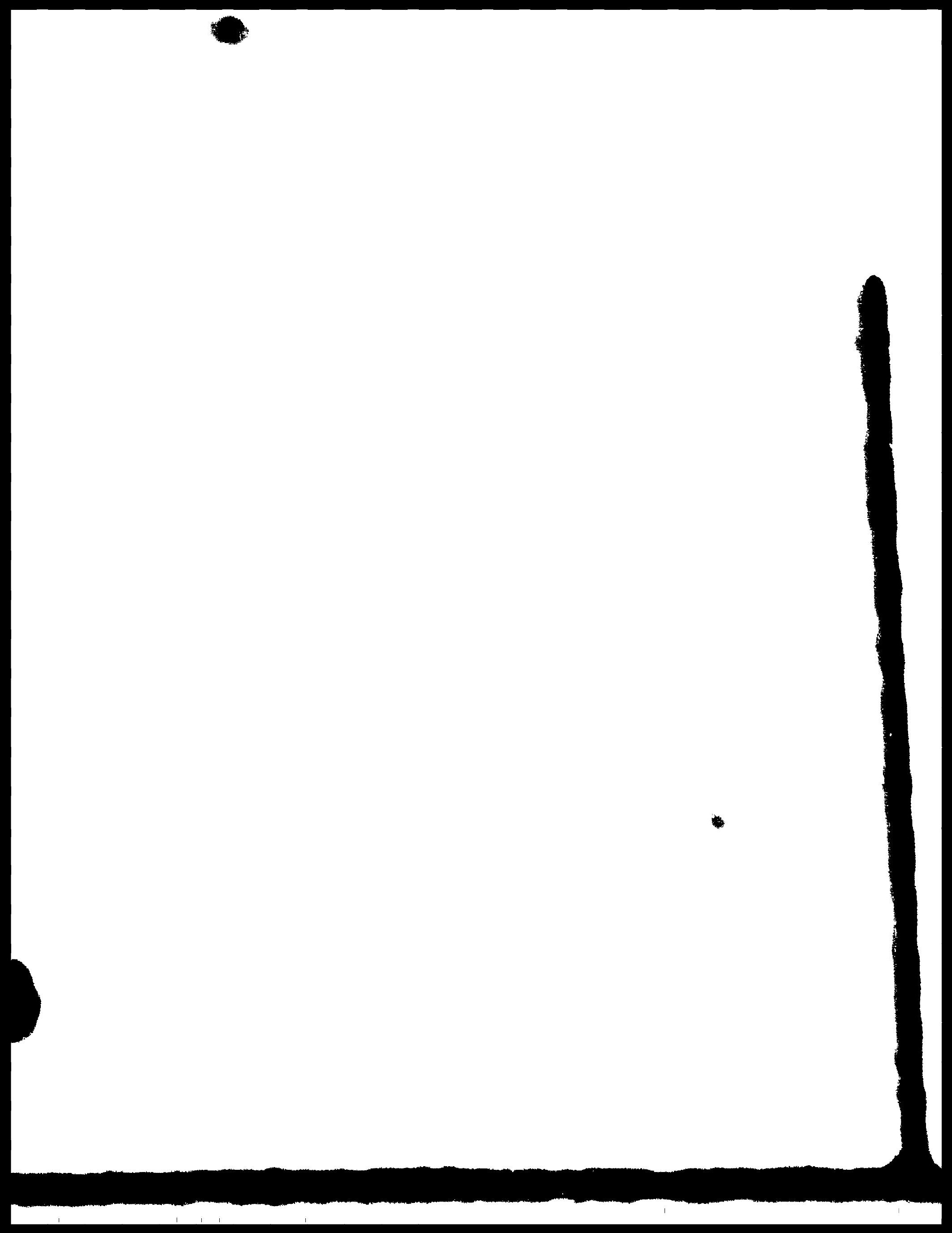


suggested by angular shards.

Though the rhyodacite clasts are not as nurnerous in the matrix-supported conglomerate as in the basal conglomerate, the clasts are larger and increase in size towards the top of the bed. The boulders tend to be weakly concentrated at the top giving the conglomerate bed the appearance of a coarse-tail graded sequence. The average myodacite clast is $20 \mathrm{~cm}$ in diameter, but clast diameters can often be over 50 $\mathrm{cm}$. The largest clast in the Bode member, a boulder which measures $80 \mathrm{~cm} \times 40 \mathrm{~cm}$, is at the top of the matrix-supported conglomerate (Plate 10a).

Parallel stratification and faint cross-lamination are locally recognizable in the matrix. The bedding is the outlined by crude orientation of elongate hyaloclastic fragments and larger clasts. Slight grain-size fluctuations with minor coarsening- and fining-sequences accentuate the bedding. Localized lenses of clast-supported conglomerate and clast-free matrix are present, but are rarely thicker than 30 centimetres and 3-metres-wide.

Some large clasts appear to "float" in the matrix. The clasts depress the bedding, but the beds are not pierced, and overlying beds drape the clasts. In more distal sections and thinner beds of conglomerate, out-sized clasts commonly protrude into overlying beds. Isolated areas of normal grading are associated with clast-rich lenses. Cross-stratification is locally developed in the lee of large clasts, and trains of large clasts also outline crude bedding.

Near the top of the 2-metre-thick bed, the clast-size decreases abruptly at the contact with a lapilli-rich, clast-free bed, the third bed-type (Plate 10b). This contact is defined by a $50 \mathrm{~cm}$ gradational zone, where the clasts fine upwards and are greatly diminished in numbers. The lapilli-rich beds consist of aliered glass shards, broken quartz crystals, and fine to medium sand-sized grains. Imbedded in the matrix and only slightly larger than matrix shards, flattened lapilli-sized, rusty-brown hyaloclastic fragments tend to be aligned parallel to the depositional surface, although localized patches of platy 
fragments show imbrication. The fabric is defined by faint parallel lamination and incipient cross-stratification outlined by concentrations of fine dark hyaloclastic fragments and indistinct size-grading. The parallel stratification becomes more distinct near the top of the bed, 3 metres above the lower contact.

The lapilli-rich bed is rarely well-exposed. The recessive nature of the bed is due to a high proportion of carbonate cement and a lack of erosion-resistant clasts. The upper contact, where exposed, is a sharp erosional unconformity overlain by a thin cap of well-stratified medium to fine sand-sized sandstone. Sand grains are dominantly quartz and felsic lithic fragments, cemented by silica. Low-angle climbing ripples and shallow scours with amplitudes of $10 \mathrm{~cm}$ and wavelengths of $20 \mathrm{~cm}$, are the dominant bed forms.

Sandstone beds cover both examples of matrix-supported conglomerates in proximal sections. In the lower depositional cycle, the sandstone is truncated by an erosional surface (Plate 10c). In the second cycle, small pillows with unusually thin selvages rest on top of the sandstone and locally depress the bedding (Plate 8C). Baking of sandstone is indicated by a pinkish-white rim of sand around the pillows, in contrast to the usual grey-white coloration. Sandstone fills pillow interstices up to 50 centimetres into the overlying pillow flow.

\section{Distal Deposits}

Sedimentary characteristics of distal Bode member deposits are distinct from the proximal beds two kilometres to the north. The distal units are dominated by repeated normally-graded beds of fine-ash, iron sulphide-rich layers and pumice beds, truncated by shallow channel forms containing clast-trains of rhyodacite cobbles (Figure 12 and Figure 13).

The normally-graded ash beds are a sequence of beds repeated many times in a section (Plate 11b). The basal contact is erosional, consisting of shallow scours up to 2 metres across, cutting into underlying beds to a depth of 15 centimetres. The scours 
Plate 10. 
Plate 10

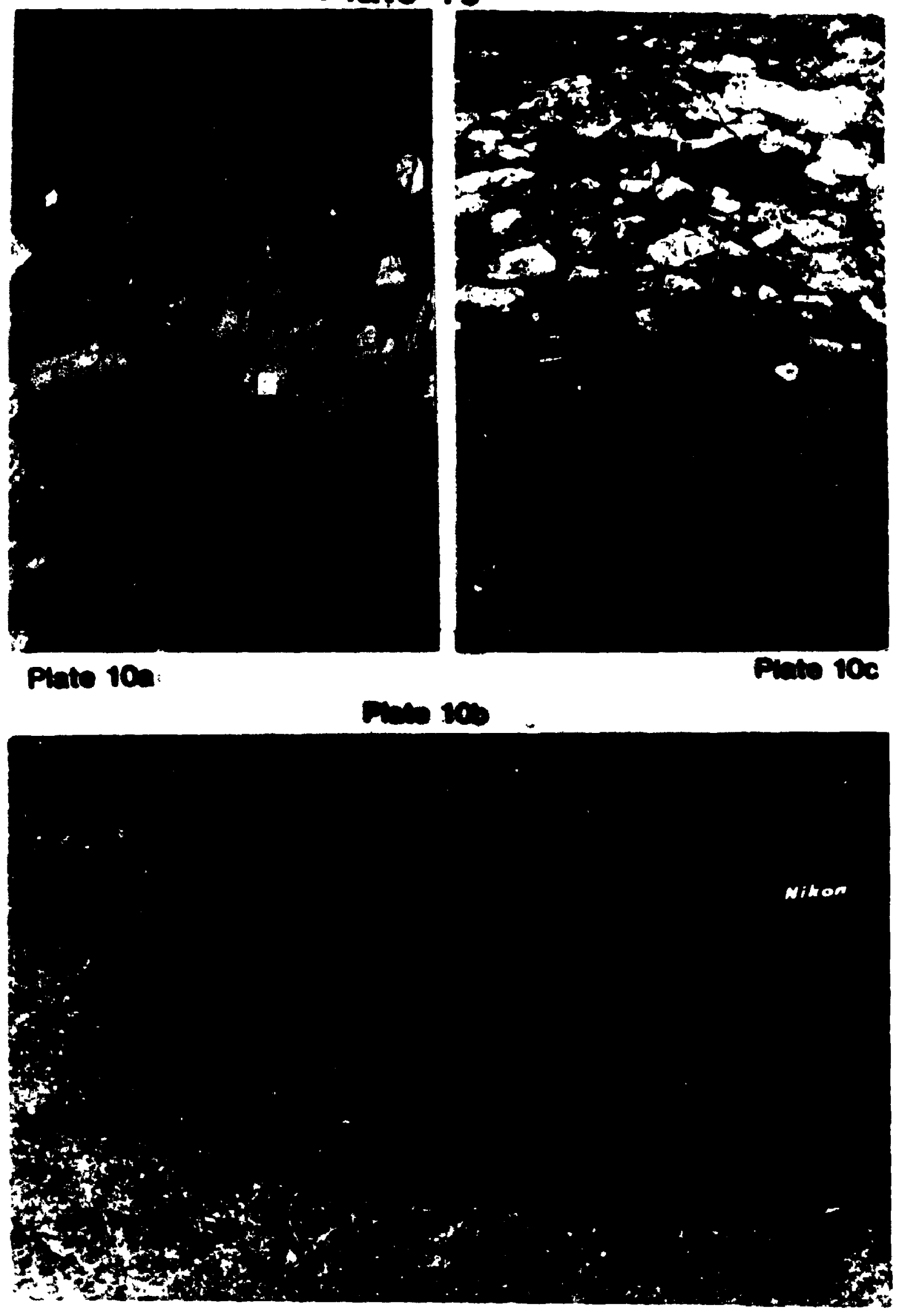


are filled by a thin, massive pebble-conglomerate similar to the basal conglomerate of proximal deposits. Clasts in the scours are pebble-sized mafic fragments, pumice shards, and srjarse rhyodacite pebbles. The bed's striking rusty appearance is due to weathering of abundant sulphide fragments. The $30-\mathrm{cm}$-thick basal unit grades abruptly into a massive sandy ash bed, with pumice-, lithic- and crystal fragments. The 10-centimetre-thick beds are generally clast-free, with only isolated out-sized rhyodacite cobbles, $10-15 \mathrm{~cm}$ in diameter. Large clasts protrude into overlying parallel-laminated sandy ash beds, with the same composition as the previous division. The sandy ash beds do not contain any large clasts, but display $2 \cdot \mathrm{cm}$-thick laminations defined by subtle variations in particle-density and size. Grading upward from the underlying parallel-laminated sandy ash beds is a parallel-laminated division composed of fine-grained white tuft. Laminae are defined by concentrations of fine dark ash fragments and size-grading. Faint cross-laminations occur in both this division and the sandy division. The last division of the fining-upwards sequence is a 3-cm-thick bed of white to light-grey chert. The chert contains very fine-grained ash, and does not show internal structures, even in thin section.

The normally-graded sequence is repeated many times in a section, but examples are rarely complete. In the transition zone between proximal and distal deposits, erosional unconformities cut through the fine-grained beds, resulting in a condensed section dominated by pebbly conglomerates. Truncating multiple depositional cycles are deep channel-forms filled with sandy ash and clast trains of rhyodacitic boulders and cobbles. The large scour-and-fill structures, 10-metres-wide and 50-centimetres-deep, cut through several older normally-graded sequences (Plate 11c). In the distal deposits, the basal erosion is not as severe, and complete sequences are more numerous. The pebbly conglomerate may be absent, with sandy-ash resting on a sharp contact with chert beds of the earlier cycle. The contact could be non-erosional, with sandy-ash resting conformably on chert. 
Setting and Sedimentology of the Bode Member

82

Plate 11. 


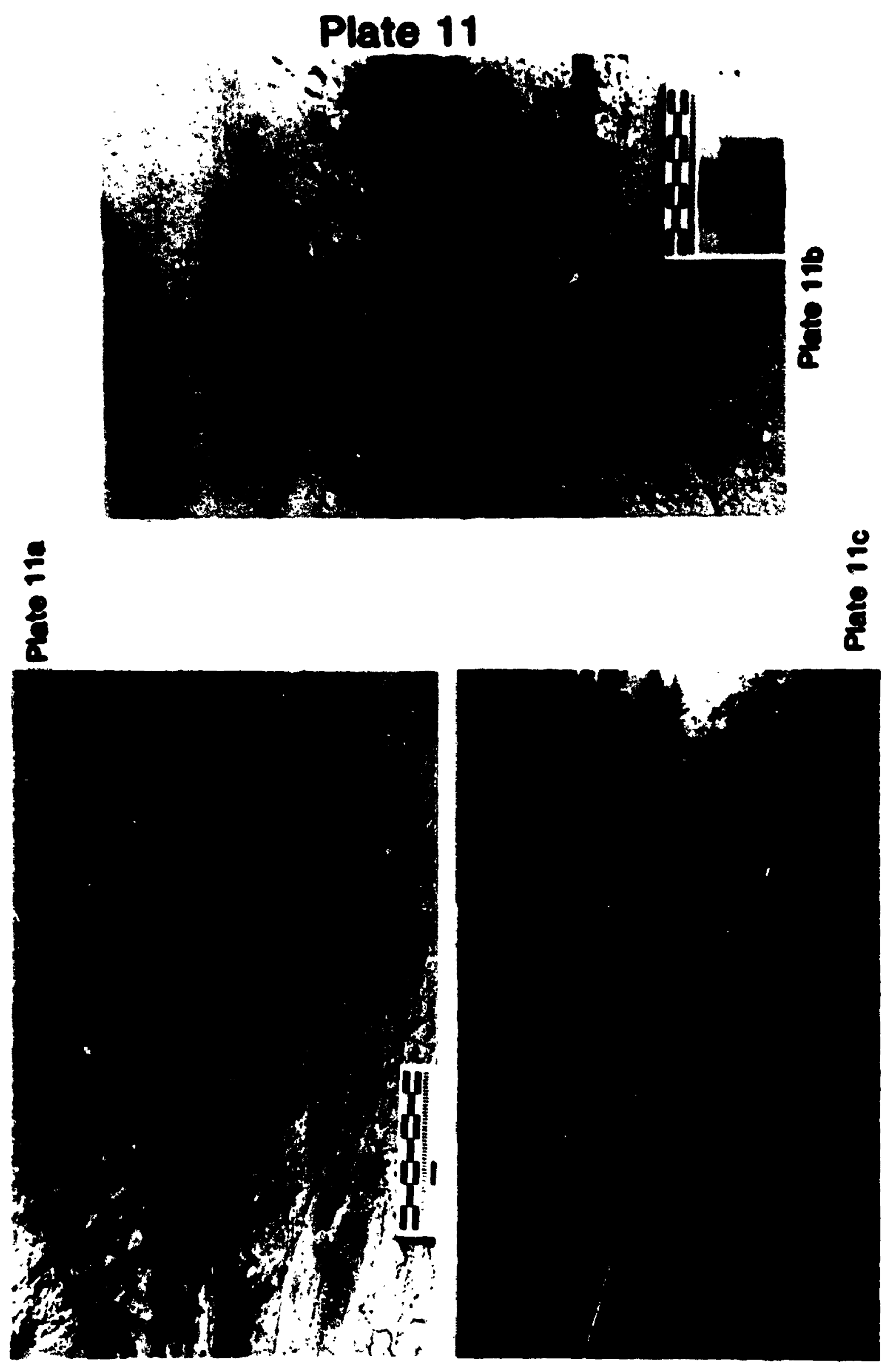


Two additional bed-types which do not belong to the normally-graded sequence are present in the distal deposits. The first type consists of thin iron sulphide-rich beds composed of fine-grained iron sulphide and allica cement (Plate 11a). The fine beds appear as laminations, rarely more than one centimetre-thick. In spite of being thin, the beds are easily visible because of rusty staining. They are not laterally extensive, and most are truncated by erosional contacts.

The second bed-type consists of distinctive, laterally continuous beds rich in pumice clasts (Plate $8 d$ ). Clast-size varies from one bed to another, but is consistent within a single bed, with little vertical or lateral grading. Lower contacts are sharp but conformable, and the tops of these unusual beds are commonly truncated by normally graded sequences. Nearly $20 \%$ of the groundmass comprises broken high-quartz crystals, 2 - $5 \mathrm{~mm}$ in diameter, and highly altered feldspar crystals.

\section{Discussion}

The pillow flows which enclose the Bode member, indicate that the "ellorex Flows were extruded subaqueously. The thickness and lateral extent of the flows exclude any interpretation of formation under subaerial conditions. Furthermore, flow extrusion was rapid. Sedimentary interbeds are uncommon in the Yellorex Flows, suggesting inadequate time for deposition of significant amounts of sediments between flow events.

Evidence for water depth at the time of Yellorex deposition is either circumstantial or non-conclusive. Studies of recently formed pillows have identified varioles at depths between 1600 metres and 5000 metres, and have demonstrated that varioles form only in deep water (Furnes, 1973). High ambient pressures at water depths below 500 metres will inhibit the release of vapour from magma. As hydrostatic pressure is a major control on magma explosivity, it can also control the proportion of lavas to volcaniclastic deposits in subaqueous eruptions (Kokelaar, 1986; Yamada, 1984). Thus, evidence of deep water at the time of Yellorex extrusion includes the absence of features ascribed to shallow 
water depths, such es: abundant volcaniclastic deposits (Kokelaar, 1886), multiple pillow rinde (Kawachl \& Pringle, 1888) and vesicular plllows (Jones, 1969; Moore 8 Schilling, 1973).

Overtying the Bode member, the \#5 Hows were deposited under markedly different conditions than those of the Yellorex Flows. The absence of varioles, accompanied by the appearance of abundant vesicles and volcaniclastic brecclas, indicate deposition in shallow water. These basalt flows were extruded above the pressure compensation level, Where water pressure is no longer sufficlent to prevent explosive release of magmatic volatiles. Modern basalts in Iceland reach the volatile fragmentation depth at $200-300$ metres of water (Fisher, 1984; Carey \& Sigurdsson, 1984).

Abundant gas bubbles can reduce magma viscosity and allow extrusion of cooler but highly fluid magma. These conditions were conducive to the formation of thin selvages, pillows with a low hoight to width ratio and abundance of drainage cavities and shelves. Hiatuses between eruptions were sufficiently long to allow deposition of well-sorted quartz-rich sandstone by currents.

In addition to morphological differences, changes in magma composition occurred between extrusion of the Yellorex and \#5 flows (Graph 1). Concentrations of the alkali elements are similar for the two flow units (Graph 2), but mid-ocean ridge basalt (MORB) normalized diagrams emphasize compositional differences (Graph 3). In MORB-normalized diagrams, the element distribution in the \#5 Hows matches an overtying pillow flow, but is distinct from distributions in the underlying Yellorex Flows. The potassium values of the Yellorex Flows are substantially lower, as are values for zircon and titanium. A higher proportion of $\mathrm{FeO}^{*}(\%) / \mathrm{MgO}(\%)$ in the \#5 flows may be attributed to Iron enrichment in the residual melt due to progressive crystallization (Graph 1)(ct. Barker, 1983).

Differences in basalt chemistry, especially increased Fo $0^{*} / \mathrm{MgO}$ ratios, can reduce 


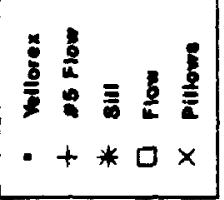

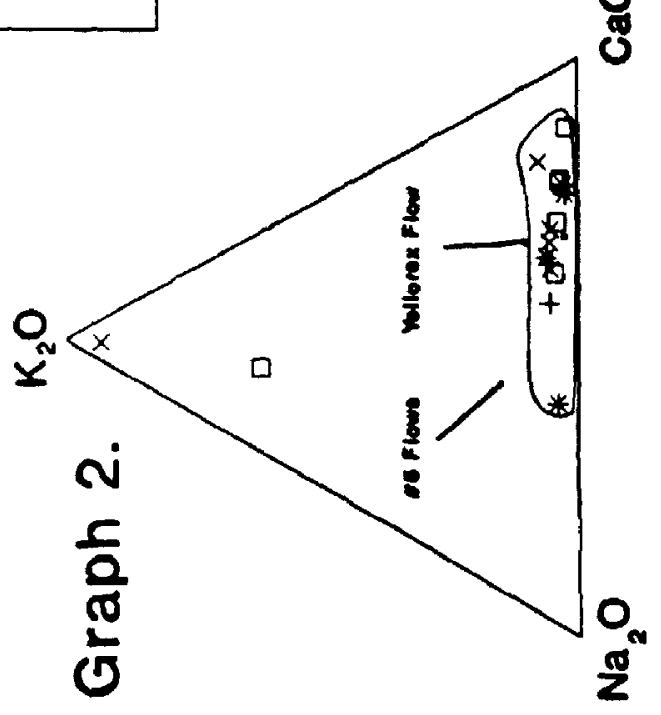

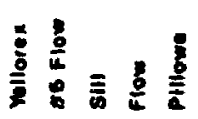

$$
\begin{aligned}
& \text { - }+ \text { * } \square x
\end{aligned}
$$

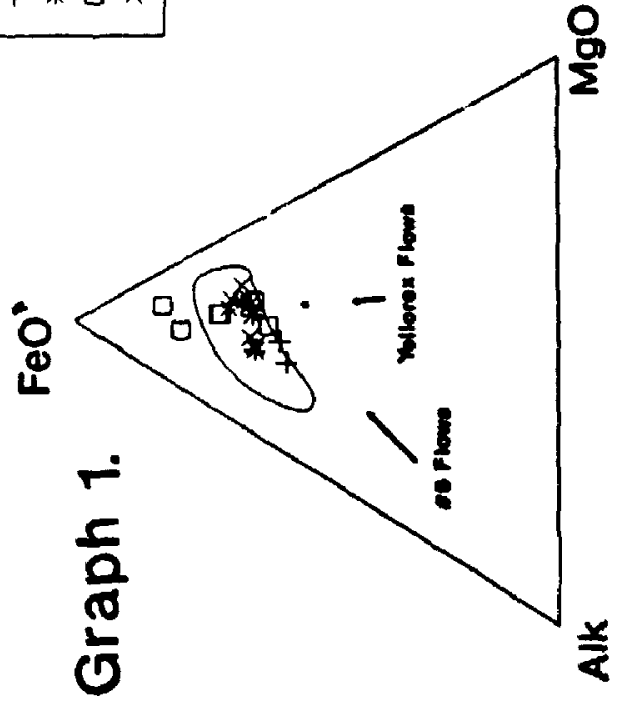

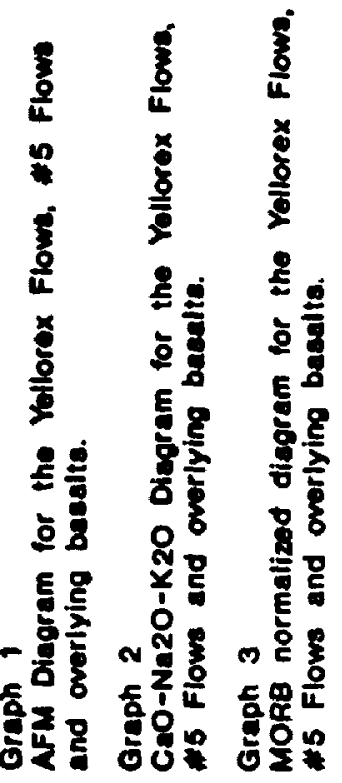

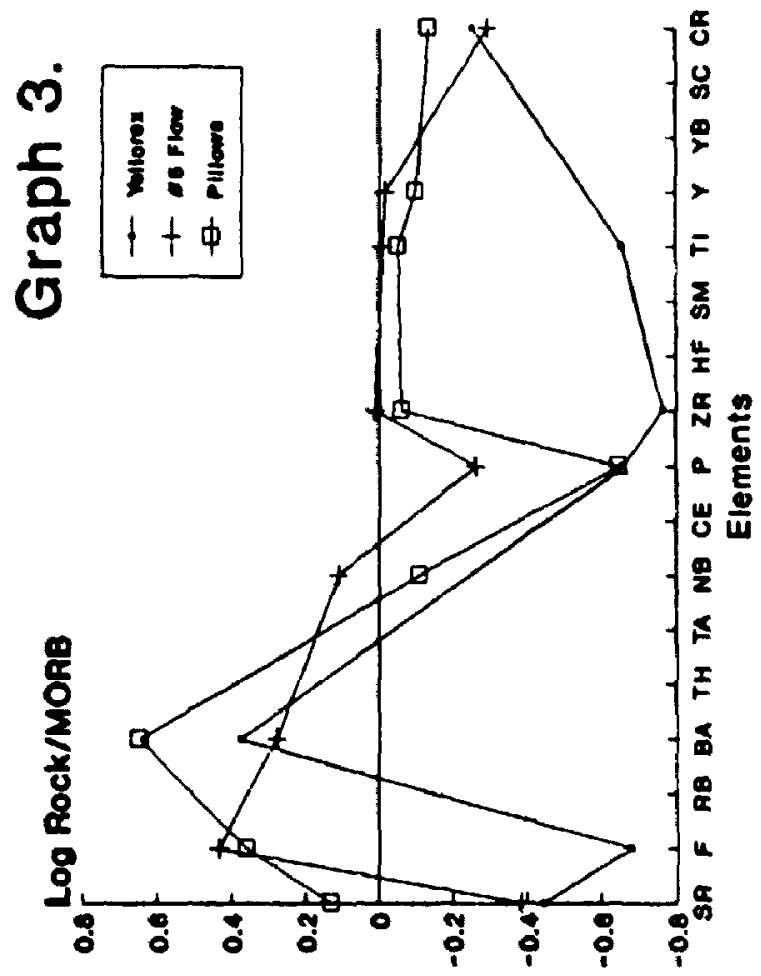


lava viscosity and consequently may have resulted in differences in pillow shapes and sizes between the Yellorex and $* 5$ flows. Similar differences have been recorded between mid-ocean ridge and lcelandic basalts (Barker, 1883). Based on evidence from the enclosing pillow flows, the Bode member was deposited during a perlod of instability when magma composition and water depth were changing, corresponding to the deep water Yellorex Flows succeeded by the shallower \#5 Hows.

\section{Bode Member Facies}

The deposits of the Bode member show some of the accumulation characteristics of lahars, a product of mass flow. Many different names have been given to thick coarse-grained "mass-flow" deposits which form in marine and non-marine environments, as a result of sediment moving downslope under the influence of gravity. The term "mass flow" covers a broad spectrum of processes, but the number of models applicable to the Bode member can be reduced, because the enclosing pillowed flows allow elimination of subaerial models from consideration.

Athough the mechanisms of flow deposition are reasonably vieil understood, the terminology of volcanic mass flows is complex and often contradictory. For the purposes of this paper, a lahar or pyroclastic flow is a highly concentrated mass flow of pyroclastic sediments and water, formed by the injection of fragments into a subaqueous environment by a volcanic eruption (Fisher 1984). Lahars thus can develop differently from non-volcanic debris flows, but both flow and depositional processes are the same (Fisher, 1984: Lajoie, 1984).

In a subniarine eruption column, volcanic debris undergoes an intense sorting which generates four main fractions: (i) lapilli that settle quickly from the eruption, to be carried away in subaqueous lahars, (ii) sand-sized ash that settles more slowly, to be sloughed away in repeated small surges as turbidity currents, (iii) finer-grained less-dense ash that settles slowly, and is transported in suspension by slow moving currents, and 
(iv) pumice lapilli that float to the surface (Sigurdsson, 1982).

Variations in typical volcanic rock facies reffect distance to source. Dykes, sills, plutons and lava flows all occur near or at the source, as do coarse-grained pyroclastlc rocks. Subaquecus lahars are further sorted during movement and have characteristic vertical and lateral facies changes. However, deposits of pyroclastic flows within a few kilometres of the eruption centre are poorly documented. Generally, framework particles progressively decrease in size away from source, although the finer constituents forming the matrix do not show a progressive decrease. Farther from the volcanic source, associated lava flows and intrusive rocks are less common, and the volcaniclastic sediments become finer grained. The proximal deposits are most strongly influenced by the eruption mode and history, whereas the distal facies are more affected by settling velocities and ocean currents. Distal subaqueous lahars interbedded with marine sediments closely resemble turbidite sequences. Fall-out tuffs commonly are interbedded with both proximal and distal facies. This depositional model is well suited to the Bode member (cf. Yamada, 1984; Fisher, 1982; 1984; Lajoie, 1984).

Clasts

Lithic clasts in the Bode member can be classified into three groups: cognate clasts, accessory clasts and accidental particles. Cognate clasts include abundant hyaloclastic lapilli and pumice tragments. The hyaloclastic lapilli and pumice fragments are glassy products of hot lava quenched in water, and are good indicators of vesiculating magma erupted underwater. The depositional manner of the two cognate clast types was however, different. Low-density pumice fragments may have been erupted subaerially and aerodynamically sorted before sinking. Thus, isolated pumice-rich beds represent fall-out beds deposited atter clast formation and eruption (Yamada, 1984; Sigurdsson, 1982). In contrast, the ubiquitous distribution of rusty-brown hyaloclastic tragments suggests an origin intimately related to bed formation. The 
fragments of chilled lava probably originated as glass spalled from magma explosively fragmented underwater, or from advancing pillows.

Accessory clasts originated as country rock ripped from vents during magma transport through the volcano (Wright of al., 1980; Freundt \& Schminke, 1985). The unique rhyodacite cobbles can be attributed to this mechanism. The well-indurated felsic ash and breccia boulders are enclosed within the thick sequence of Yellowknife Bay Formation basaltic lava flows. No source rocks are present at the stratigraphic level of the Bode member, but these cobbles do share affinities with Townsite Formation ash flows, below the Yellowknife Bay Formation. Recently acquired isotopic ages from the Bode Boulders are centred at $2.689 \pm .003 \mathrm{Ga}$. Isotopic ages for the Townsite Formation dates vary from $2.681 \pm .003 \mathrm{Ga}$ to $2.705 \pm .005 \mathrm{Ga}$, supporting the conclusion that the boulders originated from the felsic Townsite Formation (isachsen et al., 1989).

The rhyodacite clasts are well-rounded, in contrast to the angular to subangular shapes of all other clast types. This indicates differences in clast erosional history despite deposition in the same bed. The pinkish discolouration rims provide critical evidence for origin of the rhyodacite clasts as accessory lithic fragments. These reaction rims, conformable to the eroded clast surfaces, must have formed after rounding of the clasts. The presence of broken clasts with unaltered cores in direct contact with matrix indicates that the rims were not caused by subsequent metamorphic reaction with the matrix. The reaction rims are attributed to oxidation within the throat of the volcano during eruption. As magma rose up the vent, chunks of Townsite Formation could have been ripped from the vent walls. Under hot, volatile and high energy conditions in the vent, originally angular blocks could have been rapidly milled to form the rounded boulders, some of which were again tragmented during eruption. After eruption, the rhyodacite clasts were subjected to the same depositional mechanism as the body of the Bode member.

The third clast type, accidental clasts, include variolitic mafic cobbles, sulphide-rich chips and sedimentary clasts scoured from the substrate during mechanical 
transportation.

The source of the variolitic pillow fragments was the underlying Yellorex Flows. Transportation of these angular clasts was restricted to short distances, and fragments were not significantly abraded after removal from the substrate. Glassy selvages would not have remained attached to clasts under conditions of intense abrasion.

The sulphide-rich chips are small rip-up clasts derived from thin sulphide beds similar to ones in distal deposits. The angular and elongate chips indicate that the source beds were partially cemented before being eroded. The chips are concentrated mainly in basal and pebble conglomerates, suggesting that sulphide deposition was periodically interrupted by conglomerate deposition.

The other accidental clast types are sedimentary clasts that occur only in second or higher depositional cycles. Based on the similarity to previously deposited Bode units, these clasts are inferred to have been cannibalized from older Bode beds. The large clasts with transitional boundaries indicate incomplete cementation in coarse beds, in contrast to stronger induration of the finer sediments, from which the angular laminated clasts were derived.

\section{Proximal Facies}

The basal layers and pebbly-conglomerates of the Bode member rest on erosional unconformities, which in places extend several metres into the underlying deposits. Although debris flows move in a laminar fashion, turbulence might develop within the flow despite high fluid concentrations, if the flow is large enough and the velocity sufficiently high. Such conditions are common in the flow head. Turbulence allows mixing with bottom material and ambient water, as well as erosion of older deposits resulting in incorporation of accidental clasts. Close to the flow source, erosion and movement was too strong and quick for deposition. The Bode member is locally represented by a zone of non-deposition where the stratigraphic position of the member can be identified, but 
the sediments are not preserved. Typical flow-top breccia and interstitial hyaloclastite is absent from the Yellorex Flows at this horizon, eroded by the flow head. This zone of non-deposition is thus recorded by passage of the erosive base of the flow during high flow conditions, with deposition occurring only after he flow has lost some momentum (ct. Fisher, 1984; Yamada, 1984; Freundt \& Schminke, 1985). Deposition of coarse basal units in the Bode member was thus intimately related to formation of the underlying unconformity, and commenced only atter turbulence from the flow head diminished. As the flow moved downslope and incorporated loose pillow fragments, clasts, and unconsolidated sediment, the flow thinned and lower portions became highly concentrated. The resultant high concentration of particles relative to trapped water inhibited turbulence and allowed the flow to behave as a plastic. The high bulk density and large apparent viscosity values contributed to the high strength properties. These are manifested in the Bode member by the coarse-tail grading of the large clasts, some of which were transported over large distances. The flows did not really support the boulders, as fluid bulk densities cannot attain values as high as most rock. The high bulk density reduced the submerged weights of the larger fragments and greatly reduced their fall velocity. In addition, deposition of the larger clasts was inhibited by the larger surface area which is susceptible to attack by shear stresses in the flow. The larger surface areas were proportionally easier to support and transport, resulting in the coarse-tail grade sequence in the Bode member (cf. Wright et al., 1980; Fisher, 1982; Freundt \& Schminke, 1985)

As the flow velocity decreased due to reduced stresses or slope, the traction carpet progressively froze as the yield strength was reached. This resulted in deposition of a clast-supported framework with high strength, capable of resisting further motion and erosion by subsequent flows. This freezing process locked in textures and fabrics; elongate clasts are commonly oriented parallel to the depositional surface, attesting to the laminar transportation mode of the sediments. The internal layering and imbrication 
of platy fragments suggest laminar flows, but some particle orlentation may have been due to post-depositional flattening of the pumice and hyaloclastic fragments (ct. Lajoie, 1984; Yamada, 1984; Rose, 1986; Froundt \& Schminke, 1985).

Flow was not constant throughout deposition of the basal Bode member, as demonstrated by bands of clast-rich and matrix rich conglomerate. Faint cross bedding, irregular changes in thickness and interdigitation with the basal conglomerate suggest some fluctuation in flow conditions. Localized zones of increased fluidization produced bodies of better sorted coarse-ash by size-dominated segregation. Relatively better layering occurred as a consequence of separate surge peaks with different concentration parameters. These surgus developed from up-flow ponding and subsequent breaching of immobilized debris, or because of the confluence of separate flows. The surges removed previously deposited sediments and resulted in the accumulation of a composite sequence. In the Bode member, several poorly defined erosional surfaces in the basal conglomerate may mark the bases of separate flow surges (ct. Fisher, 1982). After initial deposition of the basal conglomerate in the Bode member, conditions changed and ashy pumice fragments became more voluminous. This caused the character of the conglomerate being deposited to shift from clast-supported to matrix-supported and finally to fine-grained sediment. The quantity of hyaloclastite in the Bode member suggests eruption of a vesiculating magma under relatively shallow water, concurring with the depositional environment proposed for the overlying *5 flows (cf. Freundt \& Schminke, 1985; Yamada, 1984).

In proximal Bode deposits, two cycles of basal units deposited under waning flow conditions can be identified, but both sequences are erosively truncated by rippled quartz-rich sandstone beds. The erosional bases of these sandstones suggest that, rather than being emplaced concurrently with the underlying sediments, they accumulated in response to later reworking of the lahar deposits by ocean currents. The missing fine-grained sediments were presumably removed by these ocean currents. 
The reworked sandstone separating the two cycles of coarse flow deposits marks a hiatus in flow deposition. The time required for ccean currents to erode the flow deposits and deposit the sandstone is greater than the interval between flow surges, and therefore the two flow sequences represent separate eruptions. Furthermore, the separation between the first lahar and the subsequent eruption is emphasized by the incorporation of partially cemented clasts of the Bode sediments in the second lahar. After deposition of the second cap of rippled sandstone, another eruption occurred, but it was not as explosive as previous ones. Instead, it resulted in extrusion of the \#5 flows. The hot pillows on the wet sands boiled the pore water, and a large volume of sand was thrown into the water column to be redeposited in pillow interstices up to $50 \mathrm{~cm}$ into the overlying pillowed flows.

\section{Distal Deposits}

Farther from the eruption source, the character of sediment deposition in the Bode member was less influenced by the eruption itself, and more by sediment settling velocities and currents. When the supply of particulate sediment was sufficient, it maintained the continous flow of coarse debris flows, even 2 to 4 kilometres from the source. As the column continued to settle, successively smaller amounts of fine-grained, less-dense ash fall-out were deposited, and density currents became less frequent. Lahar deposits are thinner than in the proximal sections, and fine-grained sediments and fall-out ash dominate the distal sections.

Even in the distal reaches of the Bode member, the turbulent head of the lahar maintained an erosional base. Channel-forms and scours cut into underlying sediments attest to the erosive power of the flows. The erosion may have thickened a few of the distal coarse-grained beds by amalgamating several flow deposits to produce a condensed section. The capacty of flows to transport large clasts is apparent even in the distal beds. Coarse basal conglomerates and "out-sized" clasts are common. 
Deposition of these large clasts can be attributed to an inflated flow under laminar flow conditions and not to a dropstone origin. Dropstones would have pierced and disrupted the fine bedding in the sediments. In the Bode, the clasts depressed bedding due to loading, but do not plerce or disrupt the underlying sediments. Current shadows and small clast-trains also suggest deposition by pyroclastic flows.

Above the basal conglomerates, the remainder of the fining upwards sequence commences with a parallel-laminated tuff showing ill-defined bedding at the base and gradually more distinct bedding farther up. Similar to tuffs described by Yamada (1984), the parallel-laminated sandy tuff and finer divisions probably were deposited slowly from less dense turbidity currents which separated from and lagged behind the denser preceding flows. Commonly fining-upwards sequences have no, or only a poorly-defined, basal conglomerate. Many of these sequences were deposited from turbidity currents fed by the sloughing-off of volcanic debris temporarily deposited on the flank of the volcano. Much of the debris may have been previously deposite" as the "missing " fine sediment in the proximal deposits, only to be redeposited further down slope.

The cherty-tuff division represents deposition of very fine-grained ash from clouds suspended in the water column. Laminations in the fine-grained units may have been the result of variations in pulses of turbidity currents, resulting in sedimentation on the scale of minutes to days for different beds. The lack of substantial current reworking, as is the case in the proximal deposits, suggests that deposition was rapid, and occurred in a low energy setting (McPhie, 1986).

The pumice beds and the iron sulphide-rich beds were not regular components of the fining upwards sequence, and must be attributed to depositional mechanisms other than turbidity currents and lahars. Beds containing the wispy lensoid pumice tragments lack erosional bases, are massive, and were deposited en masse. The clast composition and structure indicates a former glassy nature suggestive of pumice fragments. The absence of grading within a bed indicates sorting before introduction into 
the depositional water column.

These beds represent pumice air-fall deposits. After the eruption, the fragments and crystal matrix were aerodynamically sorted before landing in the water. Thereafter, they sank rapidly, forming sheet-like beds that blanketed the topography. The resultant beds lack the erosive bases and lithic clasts which typity the channelled mass flow deposits. The two distinct beds of air-fall pumice indicate that at least two eruptions occurred where the eruption column breached the water surface. This is further evidence for shallow water conditions during deposition of the Bode member and \#5 Flow.

In spite of poor preservation of the thin iron-sulphide-rich beds, they are important. The thin beds were deposited by precipitation of iron-sulphide minerals from solution, probably from hot water saturated in iron and sulphur, vented from hydrothermal circulation cells. Upon mixing with the cooler sea water, the sulphides reached saturation and precipitated out of solution as fine particulates. The fine crystals were dispersed by weak currents over a wide area before settling out of suspension onto the sea floor (Franklin, 1986). Even thin accumulations of iron-sulphide require extended periods of quiescent water, with little or no concurrent clastic sedimentation. Thus, the thin beds mark hiatuses in clastic deposition in the Bode member. The survival potential of these beds was low, and most were destroyed by pyroclastic flows and turbidity currents. This resulted in the discontinuous nature of the beds and the widespread distribution of ironsulphide chips. The beds must have been partially cemented before erosion, to allow the formation of angular iron-sulphide chips common in the coarser deposits.

The sulphide chips can be used as evidence of lahar timing. In the proximal deposits, only two cycles are clearly defined. The lower conglomerate bed contains an abundance of iron-rich clasts. This demonstrates that there was a hiatus between deposition of the Yellorex Member and the initial lahar, to allow precipitation and consolidation of an iron-sulphide bed. In the upper conglomerate, fewer sulphide chips indicate that conditions were unfavourable for sulphide deposition between flow events. 
The currents reworking the lower pyroclastic hows and depositing the rippled sandstone were too strong to allow the precipitate to settle locally. In the distal deposits, conditions between flow events were quleter. Several coarse-pebble conglomerate beds contain abundant sulphide chips, whereas others sontain very fow or no rip-up clasts. Beds without rip-up clasts were deposited by flows or turbidity currents occurring too soon after the earlier flows to allow the deposition of significant amounts of iron sulphide, or to let cementation harden the beds. Through the entire distal section, there is a general decrease in the concentration of sulphide clasts towards the top. If the rate of particulate sulphide formation remained constant, it can be concluded that the rate of clastic deposition ir:creased during Bode member deposition, culminating in the deposition of the *5 Flows.

\section{Depositional History}

Although sedimentation of the Bode member was not a simple, single event, the mechanisms involved were within the realm of a normal subaqueous volcanic system. Deposition of the Bode member commenced with a thin carapace of iron sulphide beds from nearby hydrothermal vents after extrusion and solidification of the uppermost Yellorex Flow (Figure 14A). During this period, the volcanic edifice was uplifted, reducing the water depth. Intrusion of magma into subvolcanic chambers may have caused or contributed to this uplift. Eventually the magma breached the seafloor, carnying with it fragments torn up from the Townsite Formation. Fragments of other lithologies may have also been incorporated into the magma, but they are not as distinctive as rhyodacite of the Townsite Formation.

Upon contact with the cold sea water, the vesiculating magma erupted explosively (Figure 14B). Large volumes of glassy fragments were formed rapidly by water quenching of magmatic ejecta. In the subaqueous eruption column, water and steam combined with the hyaloclastic ash to form a thick viscous slurry. Convection and 
turbulence carried the sediments well up into the water column, but once outside the eruption column, the sediments began to fall back through the water column. As the particles descended, factors controlling settling velocties sorted the sediments. Large fragments sank rapidly and soon reached the seafloor. Turbulence developed during this rapid descent caused the slurry to flow downslope.

When the turbulent flow moved over the surface, it eroded the substrate extensively, stripping the carapace of iron-sulphide covering the Yellorex Flows and removing loose pillow fragments. Continued input from the eruption column helped to maintain the flow's progress, but once the eruption started to subside and the eruption column collapsed, the flow began to slow. Friction with both the standing water and the seafloor caused the flow to loose momentum. Turbulence was reduced by the decreasing velocity and the increasing lithic concentration from the eroded material. With the freezing of the flow base, coarse-sediment deposition commenced.

At the end of the eruption, the supply of coarse clasts was cut off, and less dense hyaloclastic lapilli, which required longer to settle out of the water column, became the dominant sediment bsing added to the flow. With this change in sediment supply, the clast-supported conglomerate graded into matrix-supported conglomerate and then gave way to deposition of the hyaloclastite beds.

As the flow moved farther from the eruption source, the flow slowed and deposited its traction load. Less dense turbidity currents separated from the main body of the pyroclastic flow, and some overtook the flow head. These less dense flows deposited matrix-supported conglomerates, some of which were reincorporated into the. advancing main flow. Eventually the main flow froze completely, and further deposition was entirely from less dense turbidity currents.

The rapid accumulation of sediments on the slope of the volcano resulted in a temporary staging of pyroclastic deposits which were soon remobillzed. Initiation of a remobilized debris flow could have occurred when the debris was shaken by an earth 
tremor, or loaded by additional sediments. The new debris flows moved down the slope in the same fashion as lahars initlated directly by eruption, producing similar deposits. Repeated smaller eruptions may have also contributed to the composite deposits. Larger eruptions breached the water surface and ejected pumice and ash into the atmosphere. When the debris landed and sank again, it formed beds that blanketed the topography. Two such events are identifiable in the Bode member.

During periods of non-eruption, ocean currents eroded and reworked some llow deposits on the flank of the volcano. Fine-grained sediments deposited late in the eruption were especially susceptible to removal, and were dispersed over a wide area. Deeper in the basin, interruptions in pyroclastic sedimentation were marked by the resumption of iron-sulphide deposition. After the calm period, another major eruption occurred and the second cycle of clastic deposition started. The new flows partially eroded earlier flow deposits and largely removed the intervening sands. The debris of the second eruption underwent the same depositional processes as that of the first eruption debris, but because of erosion of the earlier deposits, sedimentary clasts were incorporated. After the debris had settled out of the water column, current reworking of the sediments commenced again. A final third eruption, not as explosive as the previous two eruptions, resulted in extrusion of basaltic lava to form the $\# 5$ flows (Figure 14C).

\section{Conclusions}

The Bode member maiks an important change in the pattern of volcanism in the Yellowknife Belt. Volcanism was previously restricted to massive basalt and pillowed flows, and the Bode member marks the beginning of explosive volcanic activity, a characteristic of the overlying Banting Group. Uplift that occurred between Yellorex extrusion and Bode deposition produced the shallow-water conditions and slopes required for explosive vesiculation and flow movement. Lahars issuing from the volcanic vent, proximal to the Giant Section, flowed from northeast to southwest. 
Setting and Sedimentology of the Bode Member

109

Figure 14. 

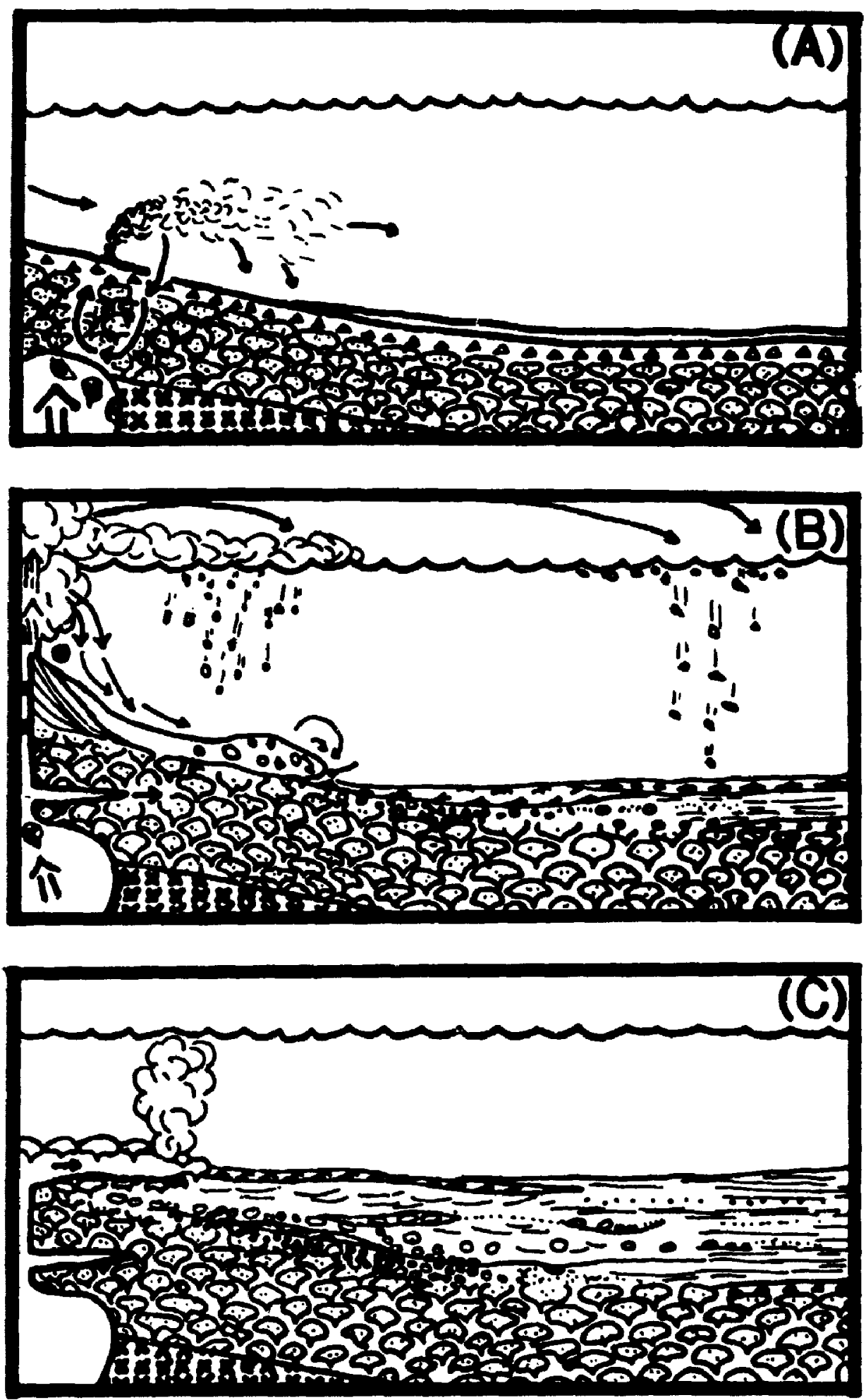
The location of the Bode member in the southern pxit of the Yellowknife Volcanic Belt, west of the West Bay fault, has not yet been established. By extrapolating on the basis of the depositional model outlined above, certain characteristics can be expected in the displaced extension. Generally, the section should be dominated by fine-grained sediments in normally graded sequences. Small matrix-supported rhyodacite clasts should be present, but pebbly conglomerates should not be common. At least two beds of air-fall tuff should be distinguishable, and thin beds of iron-sulphide should be locally well-preserved. Using this description as a guide, it should be possible to eliminate unsultable candidates for extension of the Bode member on the west side of the West Bay fault, thus providing a test for stratigraphic models developed here in the southern Yellowknife volcanic belt.

The use of interflow sediments for radiometric dating to test stratigraphic models should be approached with extreme caution. In the Bode member, the best sources of zircon are the rhyodacite clasts. However, these clasts probabiy were torn from the Townsite Formation, and isotopic ages will reflect the crystallization of the felsic formation, not deposition of the Bode member. This disparity cannot be detected by examining the zircon crystals for two or more distinct populations, because the vesiculating basalt that contributed to the Bode member did not contain significant quantities of zircon crystals.

Based on the depositional sequence of the Bode member, the association of gold deposits and sediments can be interpreted as more than mere coincidence. The interflow sediments in the Yellowknife volcanic belt marked quiet intervals during which there was little or no lava extrusion. Under these conditions of stability, circulating hydrothermal cells may have concentrated economic minerals, as reflected by the depesition of iron sulphide beds. 
The Nature of the Kam Group - Banting Group Contact in the Giant Section, Yellowknife, N.W.T. 
Introduction

Since the Yellowknifo volcanic belt was firet mapped by Jolliffe (1936; 1946), soverel stratigraphic columns have been proposed by different authore (Henderson \& Brown, 1966; Henderson, 1985; Helmstaedt \& Padgham, 1986a). Some of the interpretational differences involved the definition and subdivision of large units, but in all cases the Kam Group, thick sequence of dominanthy mafic volcanic and Intrusive rocks, is overlain by the Banting Group, a mixed package of folsic volcanic and intrusive rocks interbedded with turbiditic argillites. No consensus was reached about the nature of the Kam Group - Banting Goup contact.

In the northern part of the Yellowknife belt, an angular unconformity has been proposed to explain differences in bedding attitude between the Kam and Banting Groups. This contact has led some authors (e.g. Baragar, 1966; Cunningham, 1984) to conclude that the change from felsic to mafic volcanism was abrupt. However, the actual contact is not exposed, and in most places it lies beneath the Jackson Lake Formation. The Jackson Lake Formation, a fluvial sandstone interbedded with conglomerate lenses, was deposited in a fault-bounded valley that follows the contact between the Kam Group and the Banting Group trom the northern part of the volcanic belt, south to the Glant Section (Helmstaedt \& Padgham, 1986a) (Figure 5).

In the southern part of the Yellowknife volcanic belt, the Kam and Banting Group beds have similar attitudes, and their relationship has been described as conformable. Uniortunately, the contact is mainly submerged beneath Yellowknife Bay, and where exposed, the contact has been obscured by intrusion of a 150-metre-thick gabbro sill. The problem is further complicated by recognition of the Banting Group in the southern part of the belt. Helmstaedt and Padgham (1986a) have interpreted intermediate sediments and tuffs interbedded with mat s pillow flows and massive gabbro sills exposed in the South Islands to be lateral equivalents of the felsic ash and quartz-feldspar porphyries of the Banting Group. This interpretation has been challenged by those who 
feel that the South Islands represent a continuation of Kam Group deposition (N.R. Newson, personal communication, 1989).

The best locality to examine this problem is the Giant Section, where the Kam and Banting rocks are well exposed and clearty identifiable. Through detailed field mapping and a closely-spaced geochemical survey, it has been possible to resolve some of the controversy surrounding the nature of the Kam Group - Banting Group contact.

\section{Setting}

The lowermost unit in the Giant Section is the Yellorex Member. The pillows of the Yellorex Member are characterized by varioles of fine-grained epidote, hornblende and feldspar (Figure 9). The pillows show a large variety of shapes and sizes, and examples with one or more interconnected buds are common (Plate 1c). Measurement of directional flow indicators has demonstrated that most flows propagated towards the Southeast (Padgham, 1987c; Potts, 1988).

The variolitic lava of the Yellorex member is overlain by the Bode member, a tuffaceous conglomerate with abundant myodacitic clasts (Plate 1d). In the Bode member, rounded to sub-rounded phyric inyodacite cobbles, as well as fragments of variolitic pillows, float in a fine-grained matrix. Graded bedding and cross bedding are present in the matrix, which also contains flattened hyaloclastite fragments. The boulder conglomerate fines to the southwest, suggesting that the source of the felsic clasts was to the northeast, and the coarse nature of the Bode member further suggests that the vent was stratigraphically near the level of the Giant Section.

Resting on the Bode member is a distinctive pillow flow unit informally referred to as the *5 flows. The pillow rims are thin, and vesicles are concentrated along pillow selvages (Plate 2a). Locally, the basal unit of this complex flow unit is a well-developed pillow breccia with abundant hyaloclastite. This tube exhibits numerous branching pillows, and can be traced to a mafic dyke (Plate 2c). The top and southern end of this 
How is coarse-grained, masshe and lithologically resembles the dykes and sills of the Giant Section.

Above the $\$ 5$ complex flow is a tuffaceous quartz-rich sandstone. Ught grey in colour, it weathers white with a pinkish cast, due to contact metamorphism by an overlying gabbro sill. The 8-metre-thick sill has a chilled margin against the sand. The gabbro displays subequant amphibole pseudomorphs of pyroxene phenocrysts up to 5 millimetres in diameter (Plate 3b), and a groundmass dominated by altered plagioclase. The top of the gabbro is chilled against an overlying tuffaceous sandstone, which is in turn overlain by another gabbro sill. The next sill grades upward into an amygdaloidal massive flow where the sill/fiow contact zone is marked by a string of epidote pods up to 10 centimetres in diameter. The irregular top of the massive flow is covered by a carapace of pillow breccia.

A well-bedded coarse-grained sandstone overlies the breccia, and also encloses some of the breccia fragments. The sandstone is overlain by pillows which locally depress the bedding (Plate 4a). Pods of sandstone one metre above the base of the pillow flow demonstrate that sand deposition was contemporaneous with pillow formation. Above this horizon, pillow interstices are filled with sandstone, and some pillows are encased in sediment. The pillowed fiow is cut by six large sandstone dykes, two of which coalesce with a sandstone bed overlying the pillow flow. At the top of the flow, sandstone fills the interstices, and quartz-rich greywacke rests conformably on the flow.

The upper sandstone is the first bed in a thick sequence of coarse-grained sandstone interlayered with irregular coarse-grained gabbros resembling sills lower in the Section. The gabbro sills locally crosscut the bedding, apophyses of chilled gabbro extend into the sand and chilled margins completely surround the sills. The sandstone is overlain by graded beds of fine-grained sandstone and cherty tuff. The easternmost limlt of the main outerop 18 composed of sandstone lenses interdigitated with gabbro.

The entire sequence is cut by a large set of metagabbro dykes and sills (Plate 4C). 
At the northern edge of the sandstone-sill complex is an irregular sheeted metagabbro dyke, 10 to 50 metres wide. These dykes, which can be traced for over 200 metres, display an abundance of vesicles and selvage-like margins with associated perlitic fractures, similar to selvages around nearby pillows (Plates 5c and 5d).

A thirty-metre-wide overburden-filled valley occurs between the uppermost sandstones of the Yellowknife Bay Formation and the next outcrops. Beyond the break in outcrop, the rocks belong to the Ingraham Formation of the Banting Group. A strikeslip fault hidden beneath the valley fill has been proposed to bring the Banting Group rocks into their present juxtaposition with Kam Group rocks. The Banting Group starts with a massive, white-weathering tuff which grades into a laminated chert (Plate 4d). This tuff is crosscut by a vein-network of grey/tan alteration. Overlying the fine-grained chert and hematite-rich layers is an air-fall tutf zone containing fragments of lapilli size and larger. Intruding the tuff is a massive gabbro sill, fed by a mafic dyke with multiple internal chills similar to those of the upper Kam Group. The upper margin of the sill is vesicular, but there is no breccia cover.

The next unit is composed of lavas in the form of "mattress" pillowed andesites with concentric banding. The pillows are fine-grained with grey/green layers at intervals of 2 to 5 centimetres. In the lowest part of the flow, pillows appear to be absent, but the layering is well developed in what is either a massive flow, or a very large pillow. The pillow interstices contain numerous angular fragments of spalled pillow rim. In close association with the pillow flow is a welded ash tuff identified as an ignimbrite (Padgham, 1980). The ignimbrite is light coloured with greenish to yellow fiamme-like lenses (Plate 5a). Broken high-quartz crystals, 2-5 mm in diameter and rare highly altered feldspar crystals form nearly $20 \%$ of the groundmass.

The felsic ash beds of the Banting Group may have been fed by a felsic dyke cutting though the mafic flows of the Kam Group (Plate 5b). This dyke has irregular margins, is generally less than one metre-wide and has silictied the enclosing mafic rocks. 


\section{Field Relationships}

In the Giant Section it is possible to recognize a gradational transition from the mafic volcanic rocks of the Kam Group to the felsic ash and sediments of the Banting Group. Both Groups are diseected by mafic intrusions, and it is important to understand how these intrusions are related to the sequence. The $\# 5$ flow is an excellent flow to study such a relationship (Plate 2c). The vesiculated pillow flow is cut by a 3-metre-wide dyke with multiple internal chilled margins. This dyke is typical of multiple dykes elsewhere in the Glant Section. Where the dyke cuts the underlying Yellorex Flows, dyke margins are parallel and straight, but in the \#5 flow, the dyke is irregular and follows pillow margins or splays-off along fractures in the pillows. Immediately adjacent to the dyke's entry to the \#5 flow is an accumulation of small pillows, 20 - 30 centimetres in diameter. These pillows are atypical for the flow and are concentrated only around the dyke, reminiscent of an agglomerate mound.

Above th.a small pillows, it is possible to trace the dyke margin as it diverges from the dyke and merges with a pillow selvage. The pillow, a 5-metre-long tube, is completely surrounded by selvage except where it contacts the dyke. Numerous smaller pillows branch away from the larger pillow, including a small pillow at the end of the tube. The pillow appears to have been fed directly from the dyke. Subsequent magma pulses followed the same path and extended the dyke through already formed pillows to feed new pillows, thus building the flow unit.

The dyke extends further up the section, to a 5-metre -thick gabbro sill at the top of the \#5 flow. The dyke does not cut the sill, nor is it cut by the sill. Instead, the dyke margins turn and become parallel to bedding, merging with the sill margins. Several internal chilled margins also parallel the dyke margin and become internal chilled margins within the sill. Forty metres south of the dyke, the sill separates into more than a dozer, long, thin pillows. Thus, dykes in the Giant Section not only extruded pillows directly but the dykes also fed large sills, which in turn contributed to build up of the pillowed flow 
unlts.

The upper portion of the Yellowknlie Bay Formation is dominated by a quartz-rich sandstone complex, intruded by a thick gabbro sill fed by a large multiple dyke (Plate 4C). Sills branch from the main dyke and intrude the sandstone beds, often paralleling indlvidual laminations for over twenty metree. The sills have chilled margins, where basalt is in contact with the baked sandstone. Small dyklets of sediment have been injected into the base of the sills and locally, small dykes of mafic rock extend into the sediments. The boiling of pore water by hot magma probably promoted the injection of sedimentary dyklets into the base of the sills. The absence of brecciation of the mafic magma under water-saturated conditions is attributed to the confining pressure of the sediments.

The confining pressure also was important in controlling the width of the main dyke and the manner of sill intrusion. The multiple dyke has a constant width of 10 metres, where it cuts through volcanic units, for over 100 metres. Upon reaching the sediments, the dyke broadens to a width of over 50 metres, with a multitude of branching sills. The solidified volcanic rocks were competent and effectively contained the dyke, but when the dyke reached the relatively non-confining sediments, the magma spread out and followed a variety of paths of low resistance.

The intrusion complex was formed only a short distance below the seafloor. The main dyke and many of the minor dykes display features suggestive of shallow level intrusions into unlithified water-saturated sediments. Some internal chil! margins in the dykes are vesiculated, indicating confining pressures low enough to allow the release of gases from the magma. Other dykes have perlitic fractures and margins strongly resembling pillow selvages, products of magma intrusion into a water-saturated environment, prompting rapid cooling and quenching.

Intrusion by mafic magmas continued during Banting Group volcaniclastic deposition, as indicated by a 10-metre-thick massive sill, 15 metres above the base of the Banting outcrops. Multiple internal chills and subophitic textures are evident, and the 
upper margin of the sill is vesicular, without evidence of a breccia. This sill was fed by a 4-metre-wide multiple dyke which has the same lithological characteristics as dykes in the upper Kam Group, only metres away. If this dyke belongs to the set in the Upper Kam Group, then horizontal displacement along the proposed fault between the Kam and Banting outcrops is no more than $\mathbf{3 0}$ metres.

Felsic volcaniclastic rocks and intermediate sediments dominate Banting deposits in the Giant Section. However, the first evidence of felsic volcanism occurs immediately above the Yellorex Member in the Kam Group. The Bode member marks an important change in the depositional pattern within the Yellowknife Bay Formation, and may mark the beginning of the transition to Banting Group volcanism. Below the Bode member, massive and pillowed flows typical of the Kam Group predorninate, whereas above the Bode member, quartz-rich turbidite sands alternate with coarse metagabbro sills and pillowed flows.

Quartz-rich sandstone beds in the tuffaceous Bode member suggest a proximal silicic source. The volumetric increase of quartz-rich sandstones above the Bode member is additional evidence of felsic volcanism. If the gabbroic intrusions are removed from the Giant Section, the remainder would be a large volume of sandstone interbedded with a few pillowed flows. The source of the quartz and feldspar grains in the sandstone is not apparent at this stratigraphic level in the Yellowknife belt. No felsic vent facies have been recognized near the Giant Section, but the missing deposits may not have accumilated at the present erosional surface.

Northwest of the Banting outcrop and stratigraphic:ally at the top of the Kam Group is a down-faulted block of pillowed lava overlain by coarse conglomerate of the Jackson Lake Formation. The conglomerate rests on a regolith which has obscured several important features. A felsic dyke can be traced from the variolitic piliows at the base of the Giant Section into the weathered zone (Plate 5b). Samples of this dyke collected from exposures in the Yellorex Flows consist mainly of fine-grained matted sericite with 
isolated, embayed, subequant quartz crystals. The dyke ranges in width from 10 - 50 centimetres, but where the irregular dyke approaches the top of the Kam Group, it widens from 50 centimetres to almost 3 metres. At this lovel, the dyke has been extensively sheared and is indistinguishable trom sandstone at the top of the Kam Group (Plate 6b). In hand specimen it is impossible to determine the nature of arenaceous sandstone immediately above the dyk6, but in thin section, numerous features indicate that it may have been a crystal tuff, strongly resembling the massive tuff at the base of the Ingraham Formation. The felsic dyke, which does not cut the overlying tuff, may have been the source of the felsic tuff, and may represent a minor vent of the larger volcano responsible for the abundant felsic sediments in the Giant Section.

With the initiation of nearby felsic volcanism, a new source of quartz-rich sediment would have been available. Phenocrysts trom the felsic volcanic rocks are a possible source of sand-size quartz and feldspar, through crystal concentration due to the separation of shards and pumice from crystals in response to wind or upward-directed air in the eruption column, gas release and/or concomitant fluidization during transport of hot ash-flows, subsequently acted upon by normal fluvial processes (cf. Sparks, 1975; Sparks \& Walker, 1978; Ayres, 1983).

\section{Chemistry}

Detailed examination of relationships in the field demonstrated concurrence of flow extrusion, gabbro intrusion, and felsic sedimentation, but these relationships can only be established in exceptionally well-exposed and undeformed ereas. To test the applicability of relationships established in these isolated localities to larger areas, samples were collected for geochemical analysis. Samples were first collected from areas with established relationships, and then collected from the many different lithological units in the Upper Kam Group, Lower Banting Group and the Jackson Lake Formation. Analyses of samples were compared to assess the potential of chemistry as a method for 
correlating units where stratigraphic positions are not clearly delimited because of breaks in exposure or faults. Sample locations are shown in Appendix I. Whole rock chemistry was determined using X-Ray Fluorescence techniques. Volatile compounds including $\mathrm{H}_{2} \mathrm{O}$ and $\mathrm{CO}_{2}$ were analyzed by loss-on-ignition methods, and ferric/ferrous ratios were titrated. The results were recalculated to $100 \%$ on an anhydrous basis, and are listed in Appendix I.

The initial group of samples were from the $\# 5$ flow pillows and breccia, four different grain-size divisions from a gabbro sill, and a series of internal chill margins from a large multiple dyke. The Alkali-FeO*-MgO (Alk $=\mathrm{Na}(\%)+\mathrm{K}(\%), \mathrm{FeO}^{*}(\%)=$ Total Iron as $\mathrm{FeO}$ ) diagram displays a pattern for the major element distribution which is consistent with other plots as well (Graph 4). The relationships established in the field are confirmed by the chemical analyses. \#5 flow pillows and breccia samples are chemically equivalent to the gabbro sill samples and to some of the internal chills in the mafic dyke. Grain-size does not appear to have substantially influenced the whole-rock composition.

A surprising feature revealed by the chemistry is the occurrence of two distinct populations of magma composition in a single multiple dyke. One population of samples (multiple dyke (1)) closely matches the \#5 flows, whereas the other (multiple dyke (2)) has a distinctly higher $\mathrm{FeO}^{\circ} / \mathrm{MgO}$ ratio and a lower alkali content. The \#5 flows and multiple djke (1) samples are tholeiitic; the multiple dyke (2) samples fall within the calc-alkaline range (Graph 5). Minor elements, especially titanium, are also different as displayed by the TIN plot (Graph 6) and the $\log T i / \log \mathrm{Zr}$ plot (Graph 7). The multiple dyke (2) group contains slightly lower values of vanadium than the Upper Kam Group samples, but it also contains three times the titanium and nearly ten times the zirconium. A plot of trace elements which has been normalized using mid-ocean ridge basalts (MORB) further emphasises the different characteristics of the two magma types (Graph 8). The potassium concentrations for the $\# 5$ flows are substantially higher than the multiple dyke (2) samples. Almost all other elements in the mafic dyke (2) magmas are 


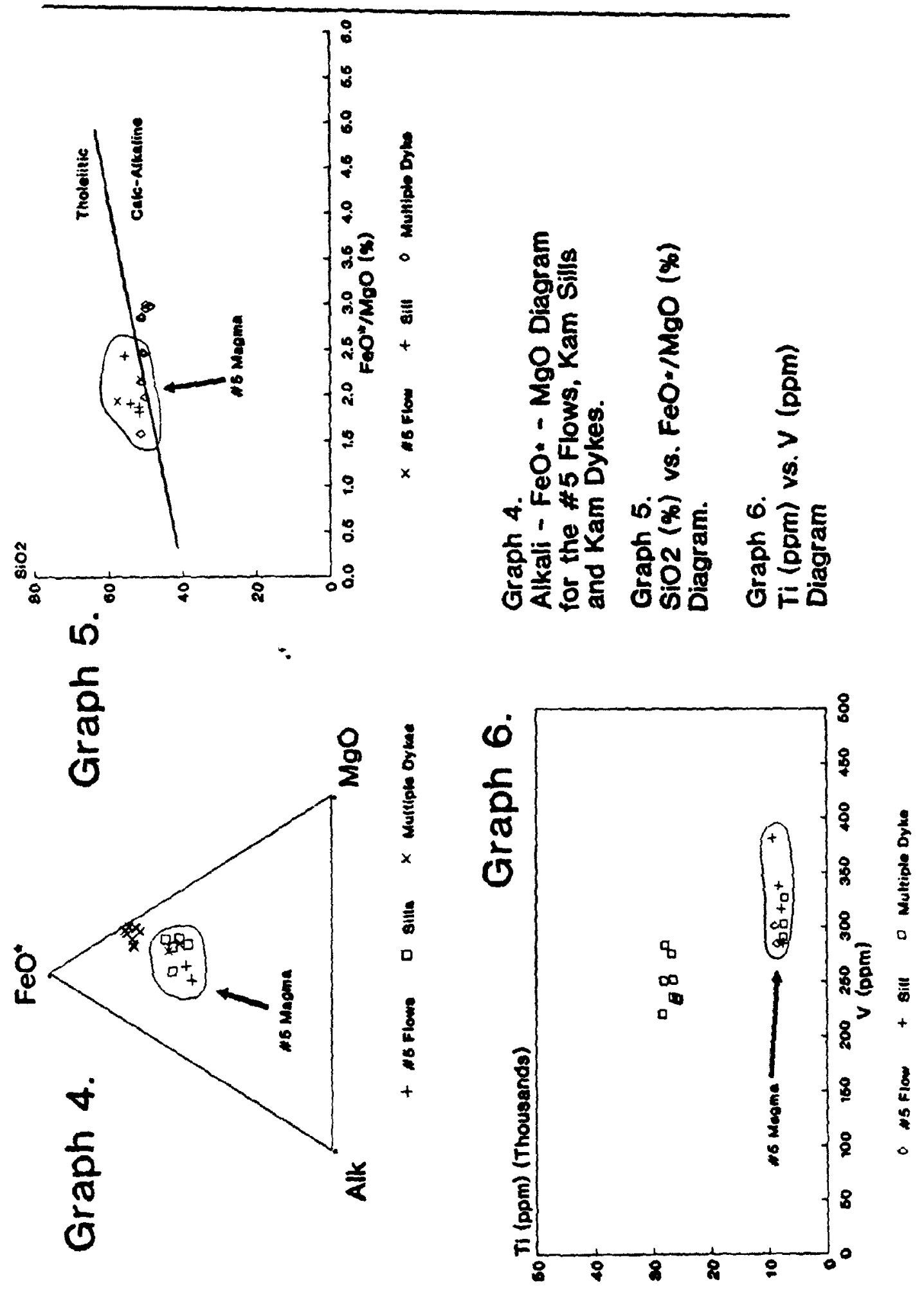



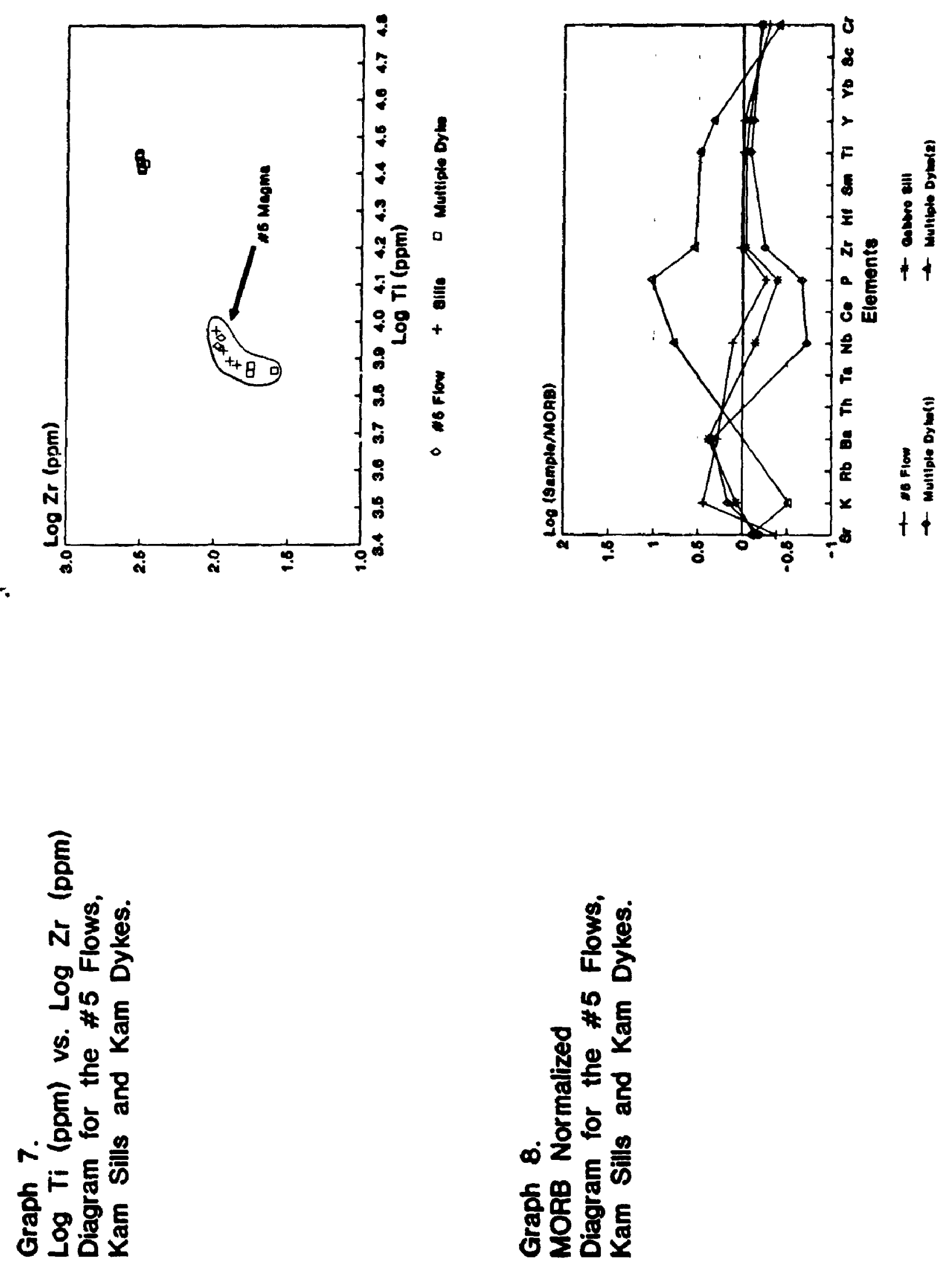
enriched relative to dyke (1), but samples trom both dykes are petrographically indistinguishable, and field relationships between the two are not easy to determine. The differences in chemical composition are too large to be accounted for by fractionation of a single magma, but "sheeting" of a separate magma source through the dyke that feeds the Upper Kam Group volcanics could have occurred.

Based on this small set of samples, geochemical analysis appears to be a potential mapping tool for the Yellowknife greenstone belt. Had all the samples demonstrated highly different values, no patterns would be recognizable. Conversely, if all of the samples were identical, it could be argued that alteration or metamorphism was responsible for uniform results. Instead, samples that were similarly altered have remained distinct, and samples that might have been altered differently have maintained similar compositions. This is not to say that the compositions have not changed since magma extrusion, but only that chemistry can be used for mapping, at least within the Giant Section.

With the establishment of geochemical analysis as a valid mapping tool, the next phase involved the analysis of mafic units where the field relationships had not bee;1 established. Included in this group are samples from the Yellorex Flows, the massive How above the \#5 flow, an epidote pod from the massive flow/mafic sill contact, the pillowed flow with clastic dykes, the mafic sill in the Banting outcrops and a sample of a "late" diabase dyke which cuts the Banting Group.

The major element AFM plot demonstrates a pattern which is repeated in the subsequent graphs. Most of the new samples plot in the "Upper Kam Group" field, but there are a few exceptions (Graph 9). The calc-alkaline / tholeiitic graph shows that most of the Giant Section samples are tholeiitic, but are close to straddling the calcalkaline/tholeitic boundary (Graph 10) (ct. Miyashiro, 1974). The lower $\mathrm{FeO} / \mathrm{MgO}$ ratio of the Yellorex Flows isolates it from the Upper Kam Group field, and indicates that the Yellorex Flows were the product of a magma different in composition from the magma 

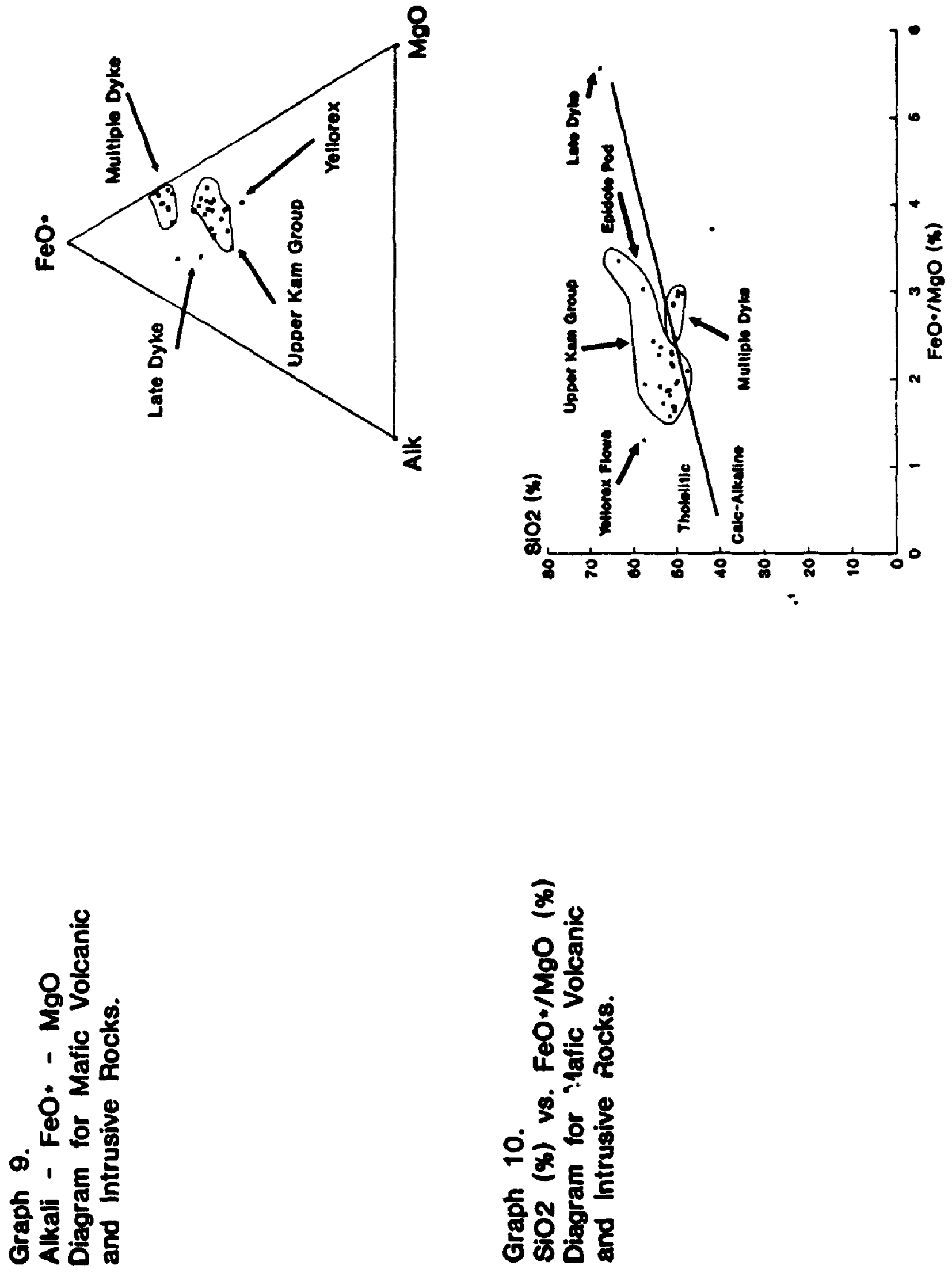
that produced both the $\$ 5$ howe and the multiple oyke. In contrast, most mafic units above the \#5 flow are chemically very similer to the "5 frow. This Includes the mafic sill In the Banting Group which was probably fed by the eame magma source. Elevated sillca values in some of the Upper Kan Group rocks correspond to vesicular samples with quartz-filled voids.

The minor element diagrams suggest four distinct magmas within the Giant Section (Graph 11 and Graph 12). Differences in the titanium, vanadium and zirconium contents are particularly pronounced. The Yellorex Flows have a low titanium content as well as low vanadium and zirconium. The overtying flows, sills and synvolcanic oykes all are slightly more enriched in these elements, but all are distinct from the multiple dyke (2) samples.

The trace element distribution can be used to separate the different sample groups more effectively than the major elements. The Yellorex Flows display a pattern which is quite different from the mafic units fed by the \#5 flow source (Graph 13). Potassium concentrations are low, as are titanium, zirconium and vanadium, whereas chromium values are higher than those typical of the Upper Kam group values. Fractionation in a magma chamber can account for these variations (Baker, 1983).

The similarities between mafic rocks in the Banting Group and the Upper Kam Group can also be demonstrated (Graph 14). The magma source for the Upper Kam Group was also the source for the Banting sills, indicating that the same multiple dyke (1) set that fed the Kam group continued to be active during deposition of the Banting Group. As all of the mafic units above the Bode member have essentially the same composition, chemistry cannot be used to identify individual flows or sills. None of the Banting samples have the same composition as the multiple dyke (2) set (Graph 15). The multiple dyke (2) samples also do not belong to the same group as the "late" dykes either. The late dyke is very chemically and lithologically distinct and easily differentiable from the Archean mafic rocks. Athough this late dyke has not been dated directly, It 

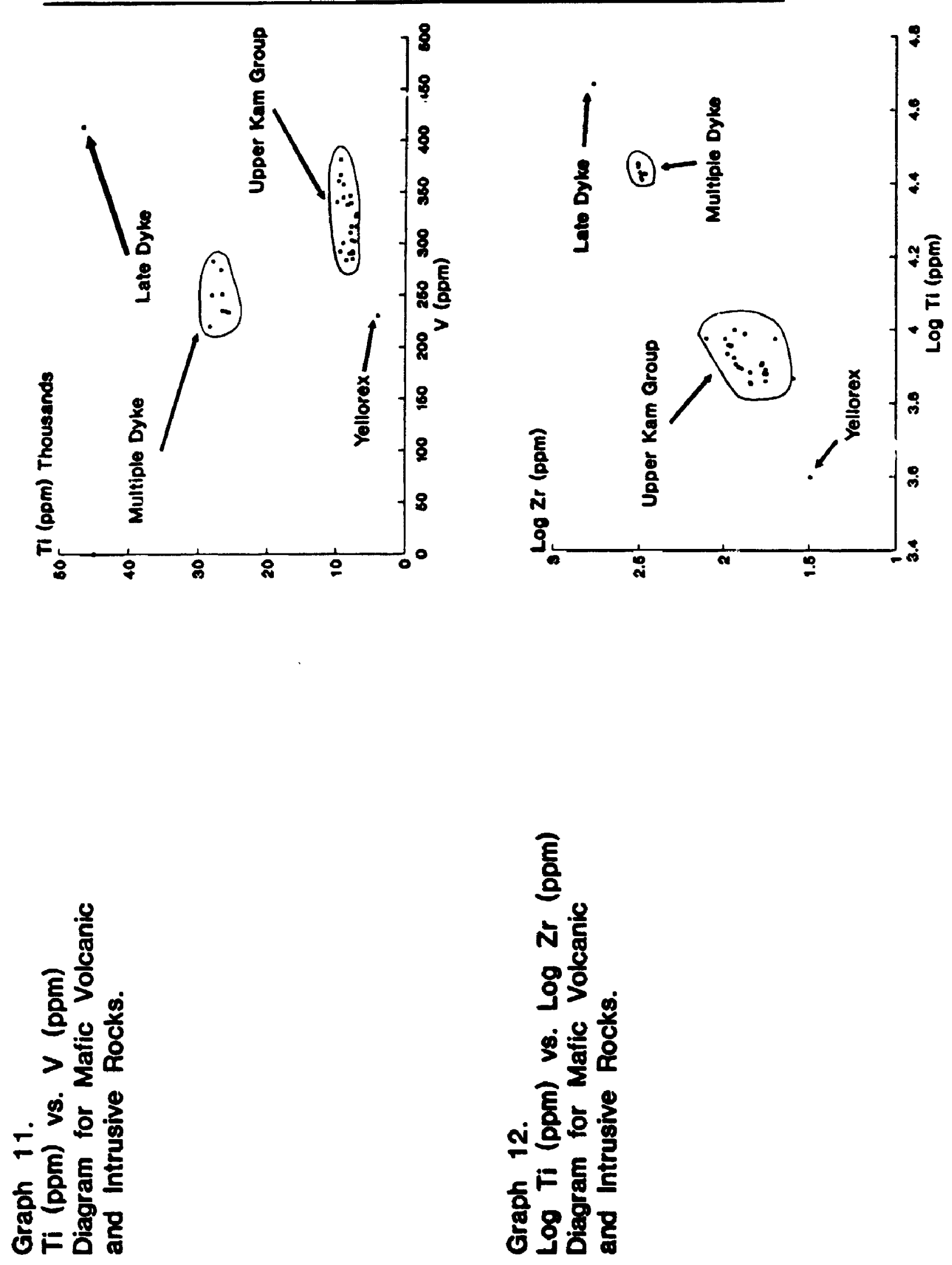

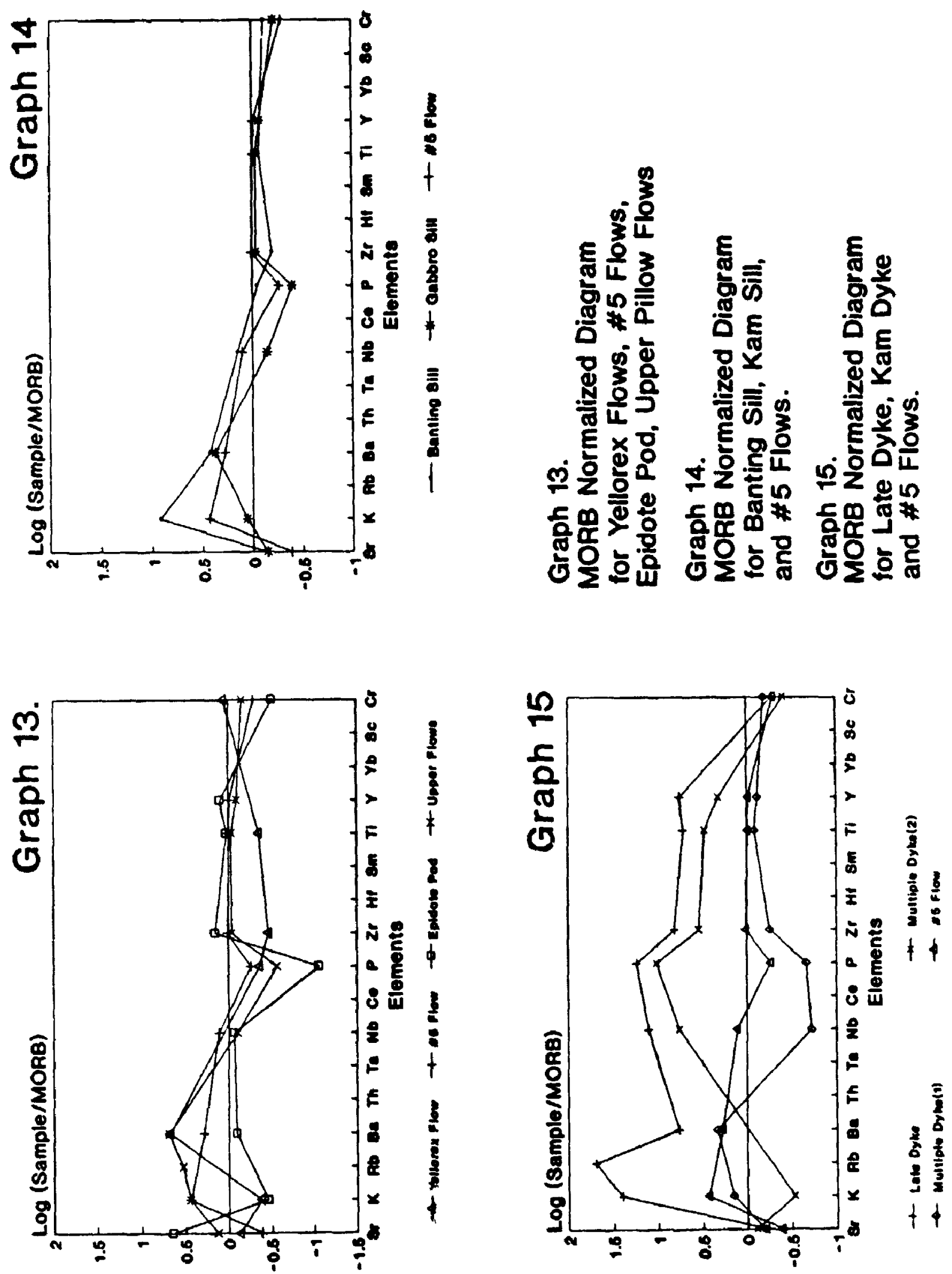
strongly resembles the Indin dykes for which Proterozoic ages have been established.

The sample from an epidote-rich pod at the contact of the massive flow and the underlying multiple sill is anomalous. The similarity in silica values between the epidote pod and unaltered samples of Upper Kam Group suggests that the alteration system was at a shallow level in the volcanic pile (Graph 10). The fluids responsible for the alteration did not depos': silica as they enriched the rock in magnesium because in a shallow alteration cell, the fluids do not travel far enough to dissolve large amounts of silica for redeposition in the epidote pods. Hydrothermal alteration appears to have a very different influence on the MORB normalized pattern (Graph 13). Strontium values are clevated, whereas mobile elements, (potassium, barium, and phosphorus) are depleted. Immobile elements such as niobium, titanium, yttrium and zirconium remain close to their original values. The conclusions from the field evidence suggest that the heat source for the alteration system was the sill immediately below the horizon of epidote pods. The sill formed soon after deposition of the overlying pillowed flow, and therefore the epidote pods formed only $\mathbf{4 0}$ metres below the seafioor.

The felsic volcanic and sedimentary rocks in the Giant Section are not as amenable to classification. Mixing of sediments from different sources has resulted in sample populations occupying large fields in the different chemical plots (Graphs 16 and 17). The major element plots show that the turbiditic sandstones which cap the Kam Group in the Giant Section have compositions similar to ash flows in the Banting Group. The Bode boulders and the Banting Group ash flows are also similar, but the amount of variation within the different sample groups permits only tentative conclusions. The Jackson Lake Formation samples clearly show the influence of different sediment sources, with the mafic Kam Group as the predominant source.

The plots of titanium vs. vanadium and titanium vs. zirconium display similar patterns, but they support the conclusion that the felsic dyke may have been a feeder to the Banting ash and a source for the Kam sandstone (Graphs 18 and 19). Chemical 

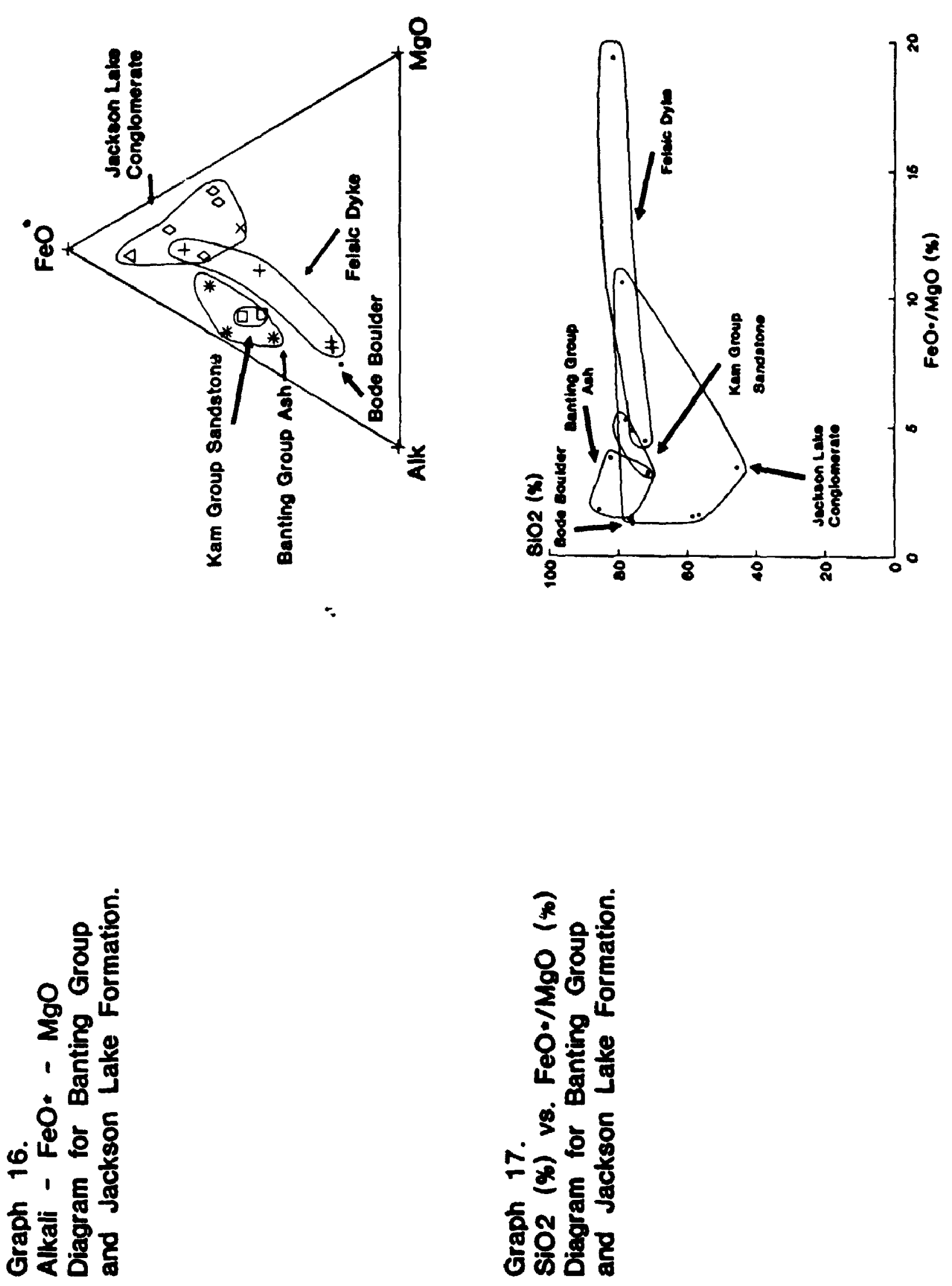

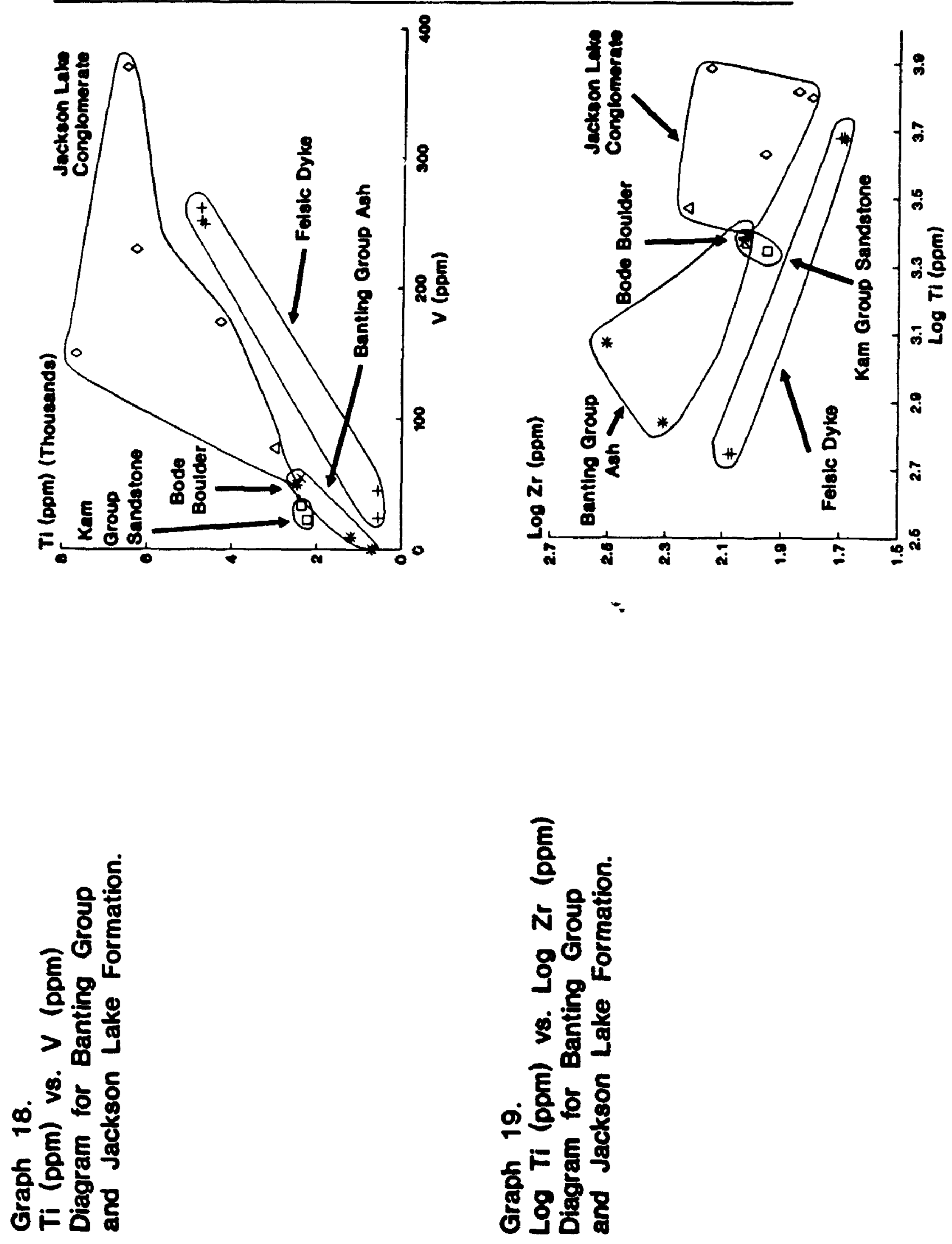
analyses suggest errors in the field identification of the felsic dyke contact with the enclosing silicified mafic volcanics. The cluster of felsic dyke samples with elevated trace element values belong the silicic halo of altered mafic rocks surrounding the dyke and not to the dyke itself. The trace elements have remained fairly constant in the former mafic rocks, but the major elements were suhstantially changed by alteration.

MORB-normalized diagrams indicate the similarity of all of the felsic samples (Graph 20). The trace-element patterns for the Bode boulder and the Kam Sandstone are virtually identical. The similarity of these patterns supports the suggestion made from the field relationships that these felsic rocks have the same source and represent proximity to a felsic centre.

Jackson Lake Formation samples can be divided into three distinct groups: quartz-rich lithic arenite, mafic-rich conglomerate and felsic-rich conglomerate. In spite of marked differences in apparent composition, the trace element patterns are remarkably uniform (Graph 21). The inclusion of Banting Group rocks in the matrix of the Jackson Lake samples is apparent from the similarity of patterns. Elevated phosphorus values in the Jackson Lake sediments can be used to distinguish them from the earlier sediments of the Kam and Banting Groups.

\section{Discussion}

In the Giant Section, the combination of mapping and geochemical sampling demonstrate that the Kam Group - Banting Group contact is a transitional and conformable contact.At the end of Yellorex Flow extrusion, the magma composition changed as is expressed by the tuffaceous Bode member and the \#5 flnws. $\mathrm{TI}$ ise were fed by synvolcanic feeder dykes and sills. Simultaneously, felsic dykes cut through the Yellorex Flows and upon reaching the sea floor, began erupting ash, pumice and lapilli. The first deposits were rapidly reworked by ocean currents and resulted in quartz-rich sandstones. 

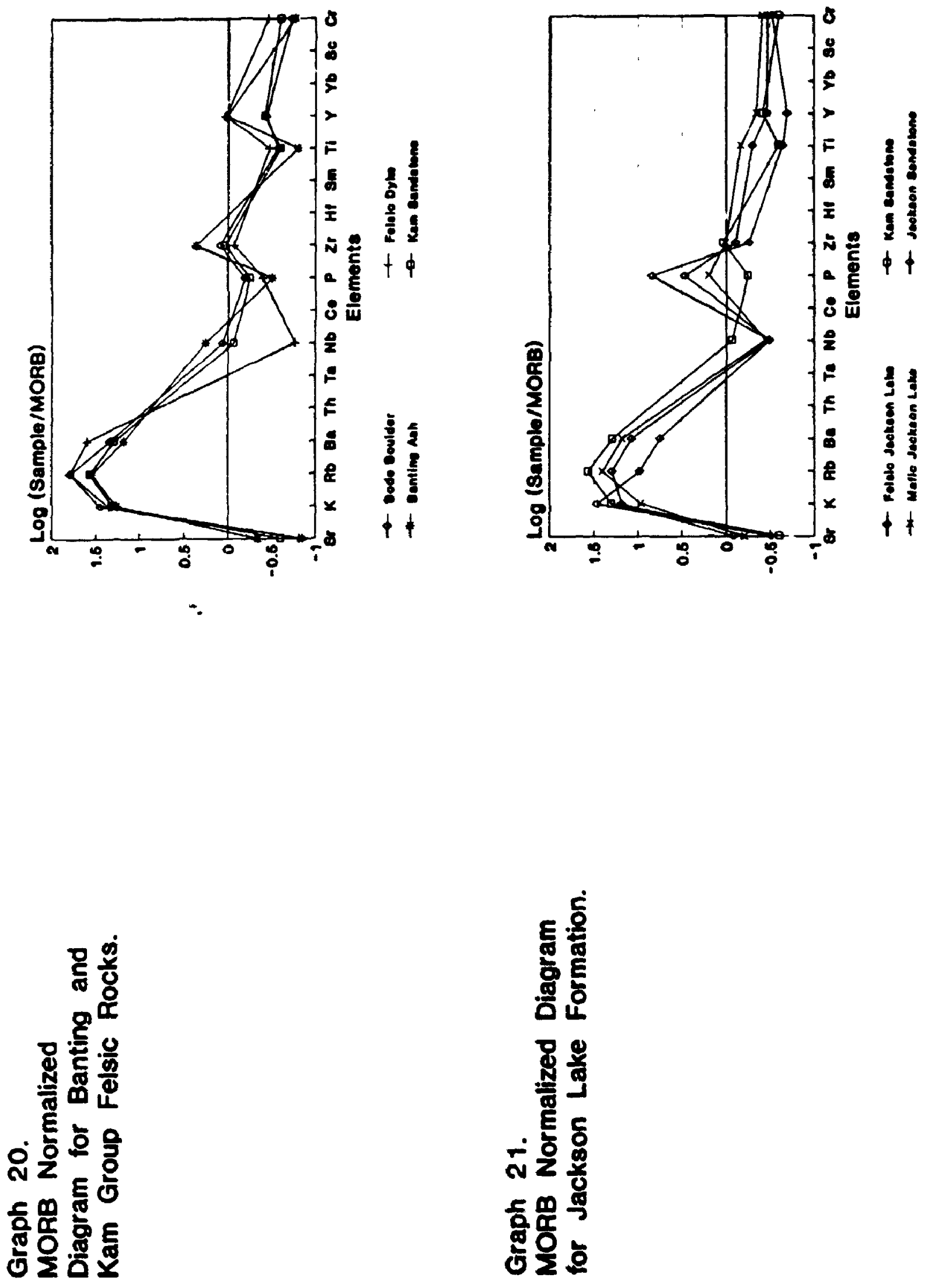
As more felsic dykes breached the seafloor close to the Giant Section, the rates of ach depositicn increased, and the erupted volumes were greater than the currents could rework. The rate was also faster than the rate of pillow formation from concurrent mafic eruptions. When the mafic magma advanced to the seafloor, it now had to break through a thick layer of unconsolidated water-saturated ash and sediment. These sediment layers could not confine the pressurized magma, and consequently the magma spread out in the form of the sill/sediment complex forming sills instead of reaching the seafloor and extruding as pillows. After Banting Group volcanism was well established, the source of mafic magma changed. The new titanium-rich magma followed the path of least resistance to the surface, through the already existing mafic dykes.

Instead of an abrupt and unconformable break between mafic and felsic volcanism, as is found in the northern part of the Yellowknife volcanic belt, the Giant Section records a gradual transition. On the basis of the Giant Section evidence, Banting Group deposition for the entire belt can be re-evaluated.

The Kam Group developed as a series of southward prograding volcanic centres (Figure 15A). By the time the Yellorex Flows were being extruded, the north end of the belt was dormant, and the most active region was in the southern part of the volcanic belt. Granitic plutons began to rise beneath the north end of the belt, uplitting the northern units. Upon reaching sea level, erosion began to wear down the older deposits and the sedimentary debris moved downslope to deeper parts of the basin in the south (Figure 15B). In front of the advancing granitic plutons, felsic dykes cut through the older mafic units in the north. When they reached the surface, felsic pyroclastics were deposited on the erosional surface and began to dominate the shallow northern part of the volcanic belt. The build up of ash in the north promoted the sloughing-off of unstable felsic deposits into the basin to the south, and in the process mixing the felsic sediments with mafic sediments derived from parts of the belt being concurrently eroded. The resultant "intermediate" sediments were redeposited in the basin to the south, where 
Figure 15. 

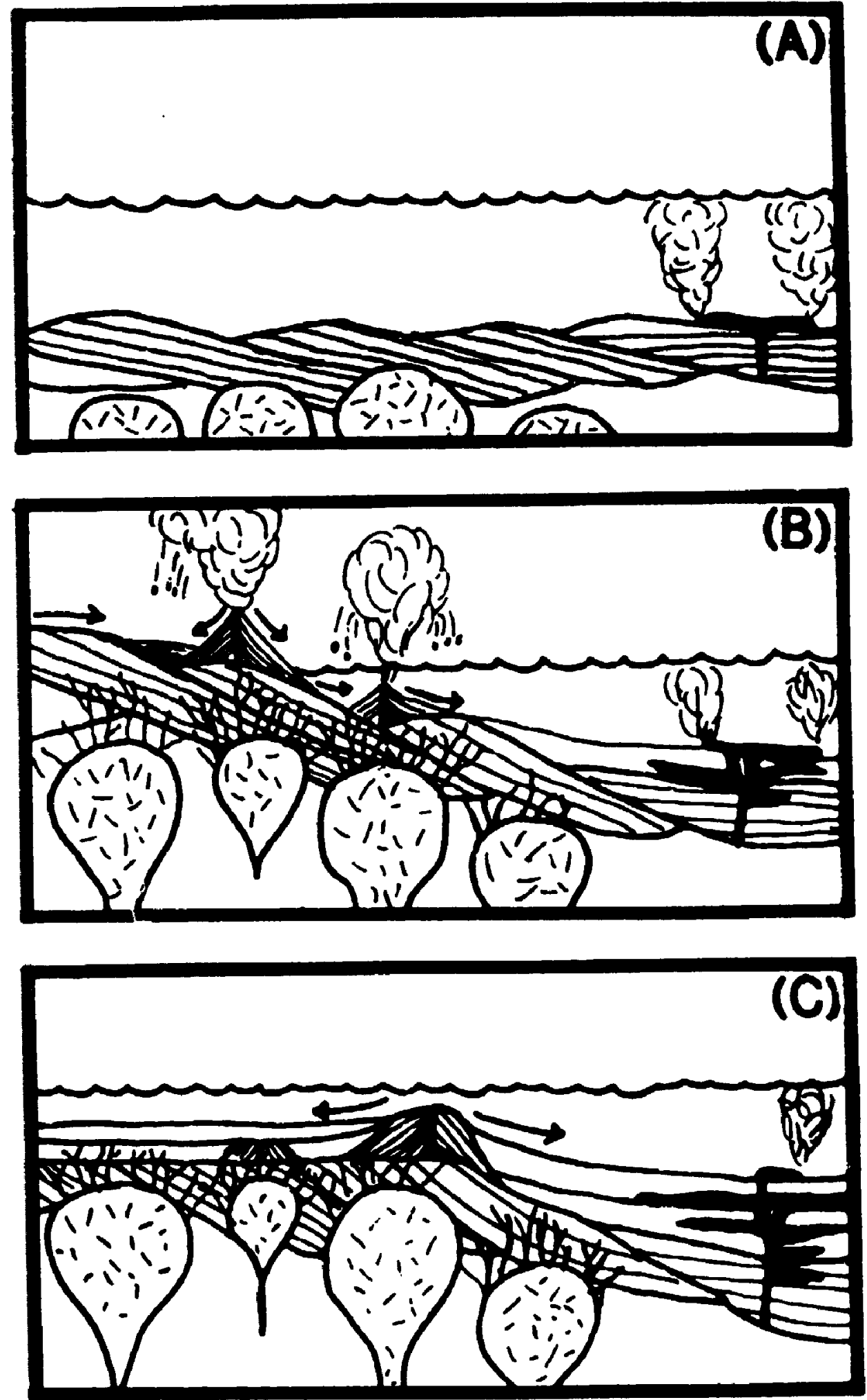
mafic volcanism was still an on-going process. Consequently the belt is left with shallowwater to subeerial felaic depusits resting on an erocional unconformity in the north, a felsic centre just north of the Glant Section fed by felalc dykes, and a thick sequence of intermediate to quartz-rich sediments and tufte interbedded with mafic flows and sills in the south (Figure 15C).

\section{Conclusions}

Closely spaced sampling in the Giant Section demonstrates that where the field relationships are well defined, the chemistry of the rocks are for the most part predictable. Ateration and metamorphism have not obliterated "patterns", and the influences of hydrothermal alteration cells can be defined. Not only does chemistry support the field mapping, but significant features which are not apparent from field mapping or petrographic inspections can be discovered. Thus, sampling can be used to compare lithological units where the field relationships are not apparent.

In terranes as complex as greenstone belts, sampling programs such as those of Baragar (1966) and Goodwin (1987) demonstrate large-scale trends, but as this study demonstrates, localized variability raises questions about correlations based on these studies. To supplement field mapping, sampling for geochemical analysis must be done systematically, with constant evaluation of the data relative to field relationships.

Concurrence of sedimentation, gabbro intrusion, and flow extrusion suggests the need for reassessment of the stratigraphy of the Giant Section, specifically the nature of the Kam Group-Banting Group boundary. Instead of an abrupt and unconformable break between mafic and felsic volcanism, the Giant Section records a transitional sequence. Multiple dykes that feed pillowed flows and gabbroic sills in the Kam Group can be traced into the Banting Group using geochemistry, where they appear to also feed both gabbro sills and massive flows. Felsic volcanism is first marked by quartz-rich sandstone beds in the Bode member, well below the traditional Kam-Banting boundary. Interbeds of 
sandstone rich in felsic fragmente provide additional ovidence of increasing felsic volcanism higher in the succession. The progression is capped by felsic ash beds and ignimbrites interbedded with mafic fiows. A folsic dyke has beon identified as a potential source of the felsic flow units and associated tephra deposits. This field evidence is further supported by geochemical data. The suggestion made by Padgham (1987b) that felsic volcanism was concurrent with mafic volcanism should be accepted and applied to mapping of the remainder of the Yellowknife Beth. 
The Origin of Clastic Dykes

in Archean Volcanic Rocks of the Giant Section 
Introduction

The Giant Section, five kilometres north of the city of Yellowknife, is well suited to the detailed examination of volcanic and sedimentary rocks in the Slave Province (Figure 8). The rocks which are exposed here, belonging to the Yellowknife Bay Formation of the Upper Kam Group in the Yellowknife Greenstone Belt, form a homoclinal succession of mafic and felsic volcanic, volcaniclastic and intrusive rocks plus intercalated sediments, all metamorphosed to greenschist facies. In spite of vertical stretching, many primary structures and fabrics are well preserved. Washed almost free of overburden by a post-glacial lake, the outcrop is also lichen-free due to acid precipitation from the nearby mine site. This combination of factors has resulted in an excellent locality for the detailed study of primary features typical of Archean terranes. These features include gabbro dykes with multiple internal chills, diverse pillow forms, intercalated sedimentary strata, and sandstone dykes. Six clastic dykes that cut across a pillowed lava flow are the focus of this study.

Clastic dykes occur in a wide variety of settings and are the product of many different processes. The term "clastic dyke" is used here to refer to a tabular crosscutting body that could have formed by the passive infill of fractures and fissures as well as the forceful injection of sediment (ct. Dionne \& Shilts, 1974; Aspler \& Donaldson, 1986). In the Giant Section, the sandstone dykes are unusual in that they occur in volcanic rocks. The objectives of this study have been to map the dykes in detail, determine the source of sediments, and to propose a model to explain the formation of the dykes.

\section{Setting}

The Giant Section is located within the property of Giant Yellowknife Mines, on the shore of Great Slave Lake. The volcanic and sedimentary rocks exposed in the section aie part of the Yellowknite Volcanic Belt, an Archean greenstone belt averaging five 
kilometres in width over a 52 kilometre length (Henderson,1985) (Figure 2). This northtrending belt is on the western margin of the Yellowknife Supracrustal Basin. The belt has been homoclinally folded, and the present erosional surface reveals a cross-section through the volcanic edifice (Helmstaedt et al.,1986).

The upper part of the Yellowknife Bay Formation is well exposed in the Giant Section (Figure 9) (Padgham, 1987c). The Yellorex Flow, a 300-metre-thick variolitic pillow lava, is the lowest stratigraphic unit. The pillows range in size from a few tens of centimetres to over 100 metres long (Plate 1c). Most pillows are elongate and are characterized by varioles consisting of fine-grained intergrowths of epidote, feldspar and hornblende. The varioles tend to be more resistant to weathering than the pillow groundmass, and project slightly at the erosional surface (Henderson \& Brown, 1966).

The Yellorex Flow is overlain by the Bode member, a polymictic diamictite with abundant well-rounded rhyolitic to dacitic cobbles (Plate 1c). Initially identified as a tuff, recent field work has demonstrated a turbidite/debris flow origin (Padgham, 1980; 1987b). Covering the Bode member is a basalt flow complex with intercalated sandstone layers. This complex of flows ranges from massive to pillowed, with many macroscopic primary textures and features, including lava tubes with drainage shelves and pillow breccias (Plate 2b).

Overlying this complex is an amalgamated metagabbro sill and metabasalt lava flow. The flow base is chilled against sandstone, and the unit is capped by an amygdaloidal lava flow with a flow-top breccia. Pockets of sandstone are enclosed in the flow-top breccia, probably as a result of incorporation of sand deposited concurrently with the breccia (Plate 3d). Breccia fragments decrease in frequency and size upwards, and the massive fine- to medium-grained sand that locally occurs in the breccia grades into a well-stratified layer ciisplaying climbing ripples.

The dyke-bearing pillowed flow is in conformable contact with this sandstone, referred to as the "lower sandstone" (Donaldson et al., 1987) (Figure 17). The pillows rest 
on a thin zone of massive sarid, and some pillow interstices aro filled with massive to faintly lamirated sand (Flate 12a). Some pillows appear to "float" in the sandstone. Sediment depusition continued during lava extrusion, as indicated by soveral discontinuolis horizons of cross-bedded sandstone, each representing a brief cessation of pillow extrusion, where sand deposition dominated over pillow formation. Uninterrupted freservation of the pillow rims suggests rapid burial; tile absence cf hyaloclastic fragments provides evidence of strong currents (Padgham, 1980).

The bas.alt flow displays abundant clongate pillows 1 to 2 metres in width and .5 to 1 metre in thickness. This is the only flow in the area where dykes have been observed. Wiih the $80^{\circ}$ dip of the strata, the present erosional surface cuts through the pillowed flow stupparallel to the direction of lava flow. This has resulted in a variely of pillow forms, from globular to elongate tubes. The total thickness of 25 to 30 matres is the composite thickness of several flows. These sub-flows can be defined by an uwwatd decrease in pillow size, discontinuous intercalations of sand and by an upward increasc in the concentration of vesicles, culminating in a horizon of sand-infilled pillow interstices.

Conformably overlying the pillowed flow is another sandstone layer informally called the "upper sandstone". This quartz-rich lithic sandstone is distinctive due to the presence of petble-sized cherty-felsic fragments. The matrix of the basal portion of the: sandstone is a massive medium-grained sandstone. Lenses of pebbly coarse sandistone occur locally, but these are rare. Hyaloclastite and pillow breccia are absent, and pillow selvages in contact with the sandstone commonly are not complete. Small sclvage fragments are contained in the sandstone, suggesting strong currents during sand deposition.

The remainder of the Yellowknife Bay Formation exposed at the Giant Section is an interbedded I thic sa:edstone/basalt flow/gabbro sill sequen c the top of which has been truncated ly faulting (Paugham, 1987c; He!mstacdt et al., 1986). 
The Yellowknife Bay Formation has been intruded by gabbroic dykes and sills. The dykes are 4 to 5-metres-thick, and some display numerous internal chilled margins, attesting to several distinct intrusive phases. Tracing of the chilled margins has revealed that some phases of intrusion can be related to specific sills and extrusive volcanic rocks.

\section{Dyke Character}

Six clastic dykes have been mapped in the pillowed flow over a distance of $600 \mathrm{~m}$ (Figure 16). The dykes range in thickness from a few millimetres to over 50 centimetres. A single dyke has been traced through the flow for over 20 meters, but none of the dykes extends beyond the margins of the pillowed flow. Drill holes have encountered the dykes at depth, and on surface the dykes appear to be laterally restricted to the Giant Section. In most places the dykes are bounded by the outer margins of pillow selvages, but the dykes also cut through pillows and infill cooling fractures (Plate 12b).

Where a dyke is between two selvages, it resembles the lower sandstone/pillowed flow contact (Plate 12a). However, a number of points indicate that the sand was not present at the time of pillow formation. The pillow selvages adjacent to the sandstone dykes are the same thickness as those adjacent to sther pillows. Had water-saturated sand come in contact with newly formed pillows, it probably would have caused more rapid cooling and the formation of thicker selvages (Plate 13a). Furthermore, no sand is incorporated into the pillow selvages along the dyke margins. This differs from selvages at the lower sandstone contact, where the lava extruded over the sands, incorporating sand grains into the selvages.

In places where a dyke cuts through a pillow core, the dyke contacts show no evidence of chilling or extensive reaction between water-saturated sand and lava (Plate 13c). In thin section, the boundary between sand and basalt is marked by a thin zone of spilitization and leucoxene formation (Plate 13b). Where sands have infilled radial cooling fractures in a pillow, the dykelets of sand can be traced to a nearby main dyke. In areas where clastic dykes are absent, cooling fractures do not contain sand grains.

Construction of a schematic cross section suggests that the clastic dykes share an angle of inclination with respect to the bedding in an underlying sandstone bed and drainage cavities in the pillow flow (Figure 16). Detailed mapping of the dykes indicates 
The Origin of Clastic Dykes

144

Figure 16. 


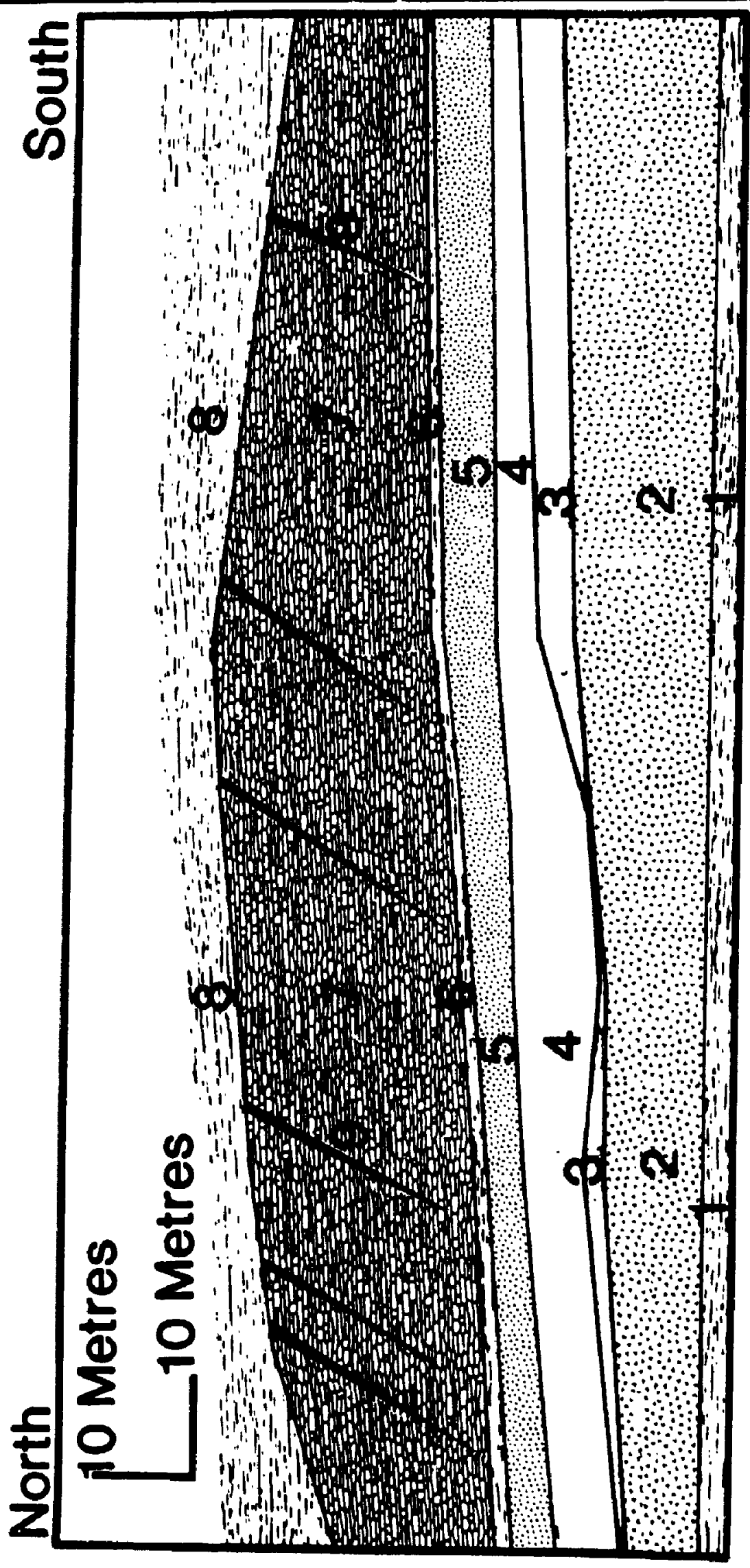


that they propagated as fractures in a stepped fashion through the pillowed flow (Figures 17 anid 18j. The stepping does not appear to be related to any tect onic fabric but reflects local inhomogeneity in the pillow flo:\%. The cause of the fracture inclination is not known.

\section{Sediment Source}

The composition and characteristics of the upper and lower sandstone provide a basis for determining the source of the sandstone within the dykes. In thin section, the lower sandstone is dominated by subrounded to subangular sand grains cemented by a carbonate/silica/chlorite cement (Plate 14a). Most grains are fragments of mafic volcanic rocks that consist of very fine-grained mats of intergrown plagioclase, chitivite and epidote, containing a few coarse phenocrysts of plagioclase and quartz. Most fiagioclase crystals are partially or completely altered to sericite, and the quartz crystals display embayments and altered rims. Other grains in the sandstone include subrounded quart grains, smaller altered plagioclase crystals, sphene and opaque minerals Hematite-stained veinlets are locally abundant.

The upper sandstone (Plate 14a) differs most from the lower saridstone (Plate 14b) in showing a predominance of altered plagioclase grains. Most of the sand grains are angular io subangular. The lithic fragments are smaller but more porphyritic, containing coarser plagioclase crystals. Quartz grains tend to be larger and more angular than their lower counterparts. Epidotized selvage fragments are common. Distinctive polycrystalline to cherty-quartz grains characterize the upper sandstone in hand specimen as well as in thin section. Such grains are absent in the lower sandstone.

Ciose examination of the sandstone within the dykes reveals that it strongly resembles the upper sandstone in both composition and texture (Plate 14C and 14d). In addition to the features which clearly identify the dyke sandstc $1 e$ as having originated from the upper sandstone layer, the dykes contain numerous pillow fragments and selvage fragments (Plate 15a). The selvage fragments are not the typical hyaloclastic fragments associated with autobiecciation, but appoar to have been broken from the margins of pillows. In some instances, the fragments have not been transported far, and it is possible to visually reassemble the fragments.

The internal structure of the dykes does not support the hypothesis of upward 
The Origin of Clastic Dykes

147

Plate 12. 


\section{Plate 12}

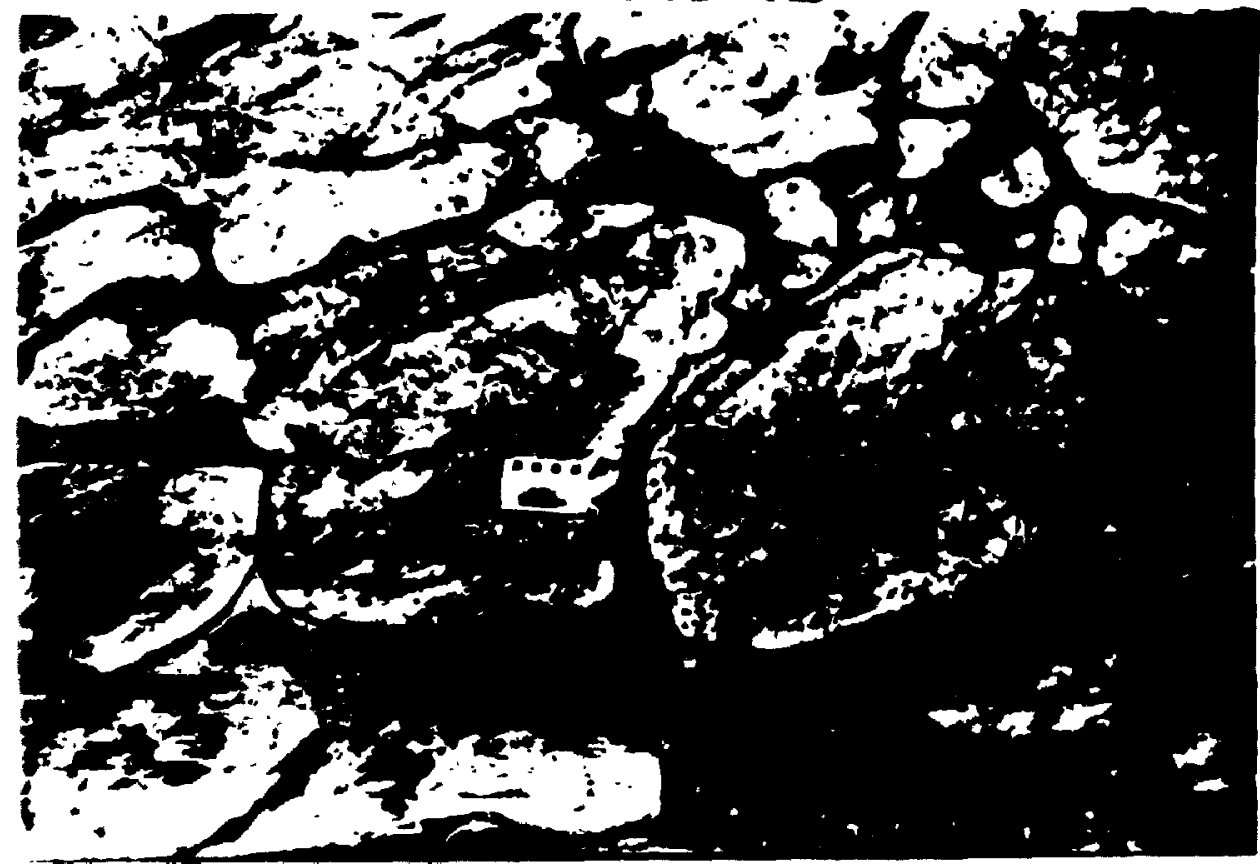

\section{Plate 12a}

Plate 12b

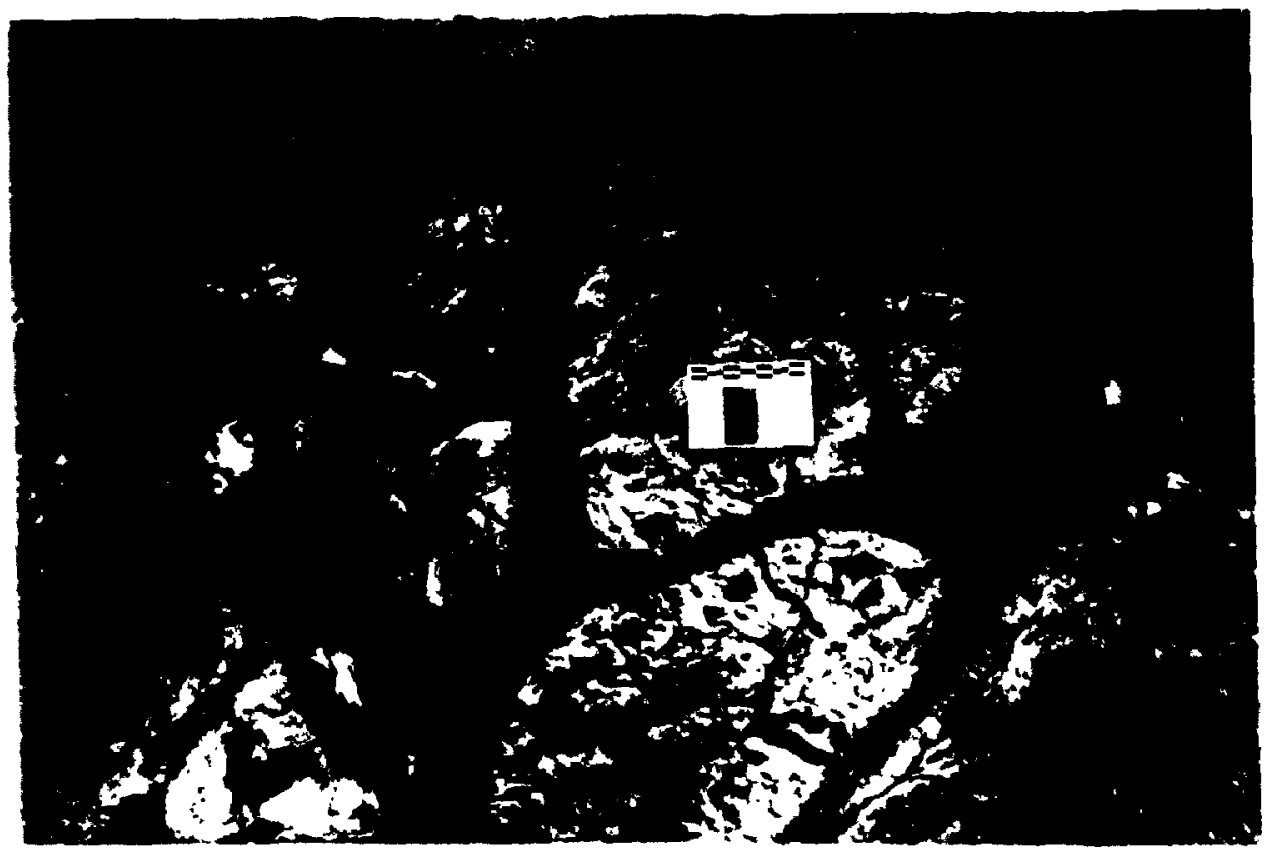


Plate 13. 


\section{Plate 13}

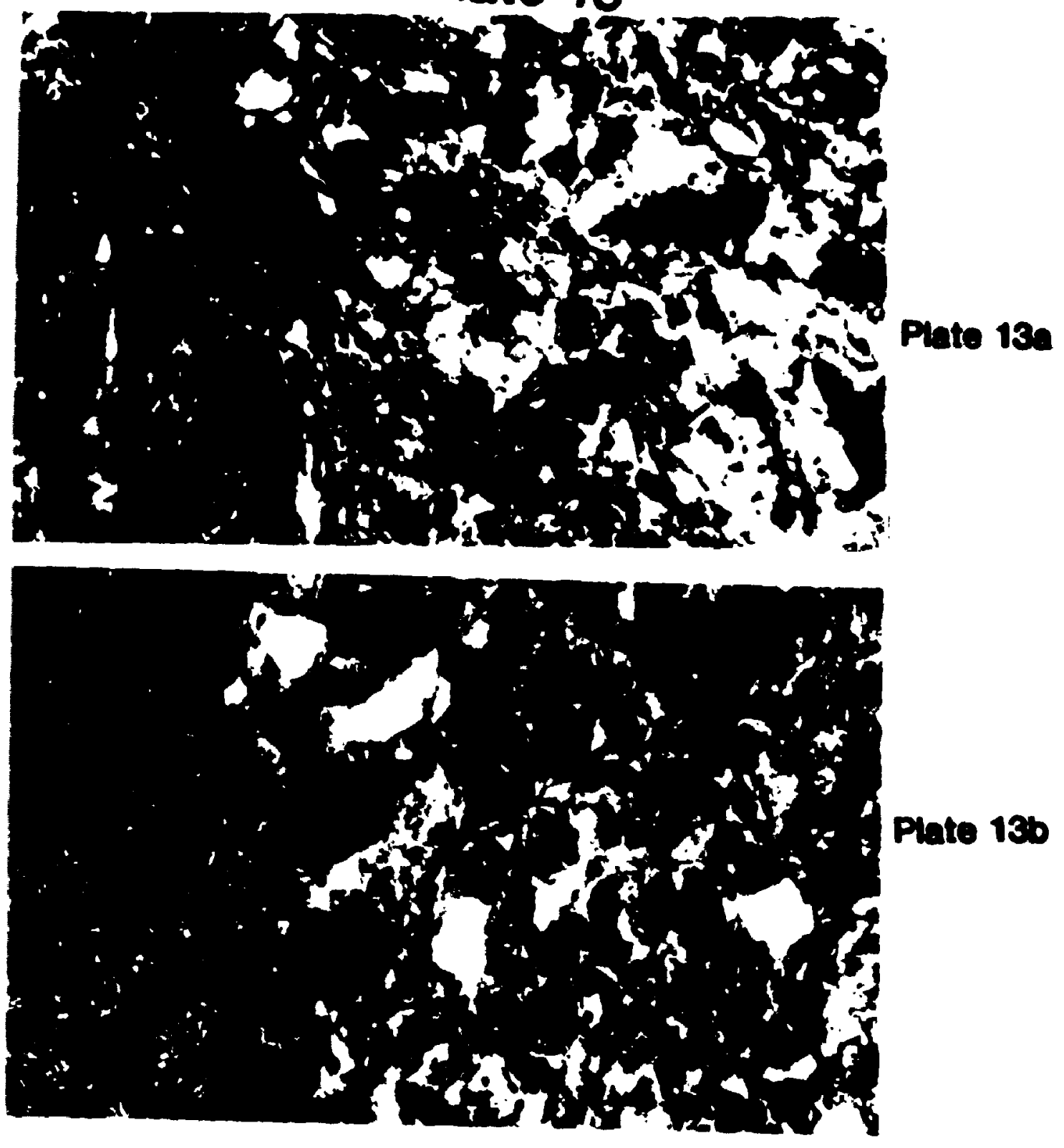

Plate 13c 
injection of sand into the dykes. There is no evidence of grain gradation or flow banding parallel to the fracture walls, as is commonly displayed in clastic dykes emplaced by forceful injection. Most of the dyke fill is maseive, with local occurrences of normal grading suggesting rapid deposition, but some crude stratification is apparent in which the laminations are parallel to the original horizontal (as deduced from the long axes of the pillows and that drainage cavities) (Plate 15b). Passive infilling from above best accounts for this internal lamination (Figure 17 and Figure 18).

The most conclusive ovidence that the upper sandstone is the source of the dyke sediments is the relationship between the dykes and the two sandstone beds. None of the six dykes reaches the lower sandstone. All can be observed to pinch out belore reaching the lower bed. In contrast, two of the six dykes can be traced to the upper sandstone (Figure 20 and Plate 15c). The upper contacts of the other four dykes are not exposed.

\section{Timing of Formation}

As with the sourse of sediment, the timing of dyke formation can be constrained. The lack of reaction between the sandstone and the basalt indicates that the basalt had already cooled substantially before emplacement of the dykes. The linear nature of the fracture walls through the centres of pillow tubes further demonstrates their solid nature. Thus, the mode of formation is not due to a downward loading of sand into still molten lava, but rather to the infilling of fractures in a pile of cooled pillowed flows. The orientation shared by the clastic dykes does not appear to be a tectonic feature rather a consequence of dyke formation. The significance of this orientation is not fully understood.

However, this must have occurred soon after restoration of the depositional environment of the epiclastic sands. The fractures do not extend above the top of the pillowed sequence, and the lower part of the capping sandstone is massive and conformably overlain by cross-bedded sandstone. Because the cross-bedded sandstone shows no sign of deformation, infilling of the fractures must have occurred before it was deposited. 
The Origin of Clastic Dykes

152

Plate 14. 
Plate 14a.

Photomicrograph of lower sandstone. Width of the field of view is $5 \mathrm{~mm}$ wide.

Plate 14b.

Photomicrograph of upper sandstone. Width of the field of view is $5 \mathrm{~mm}$ wide.

Plate 14c.

Photomicrograph of sandstone dyke. Width of the field of view is $5 \mathrm{~mm}$ wide.

Plate 14d.

Dyke sandstone displaying coarse angular fragments characteristic of the upper sandstone. 


\section{Plate 14}

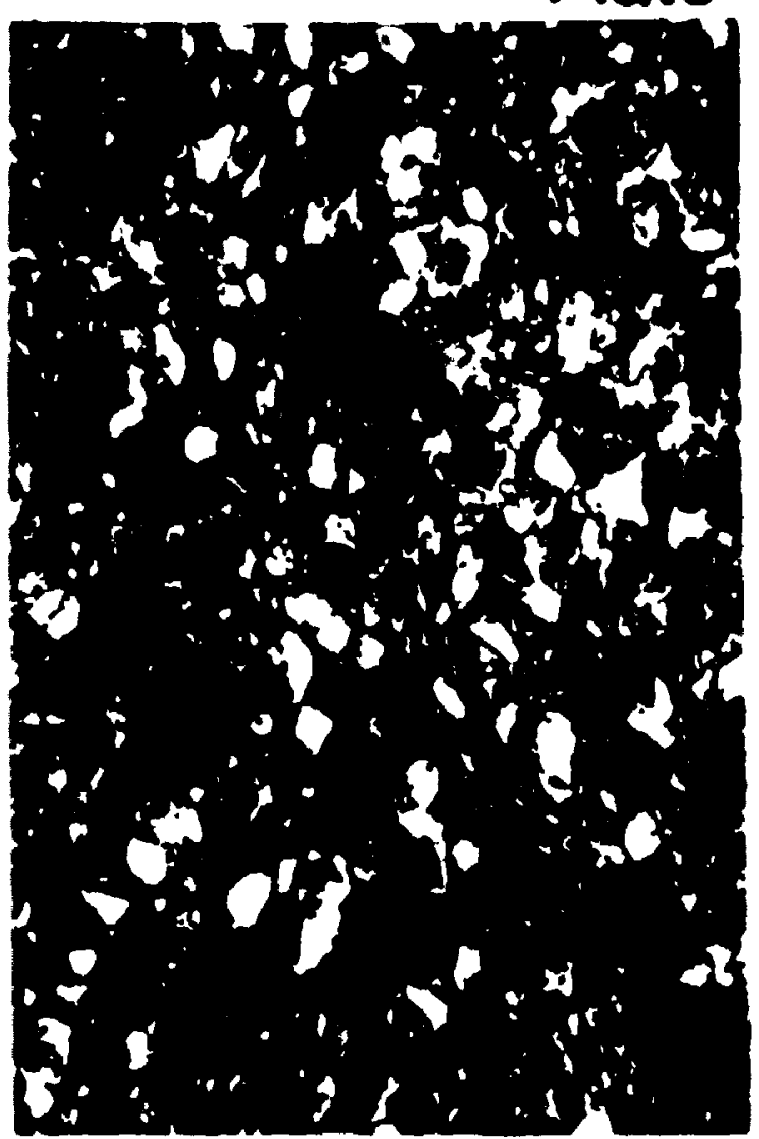

Plate 140
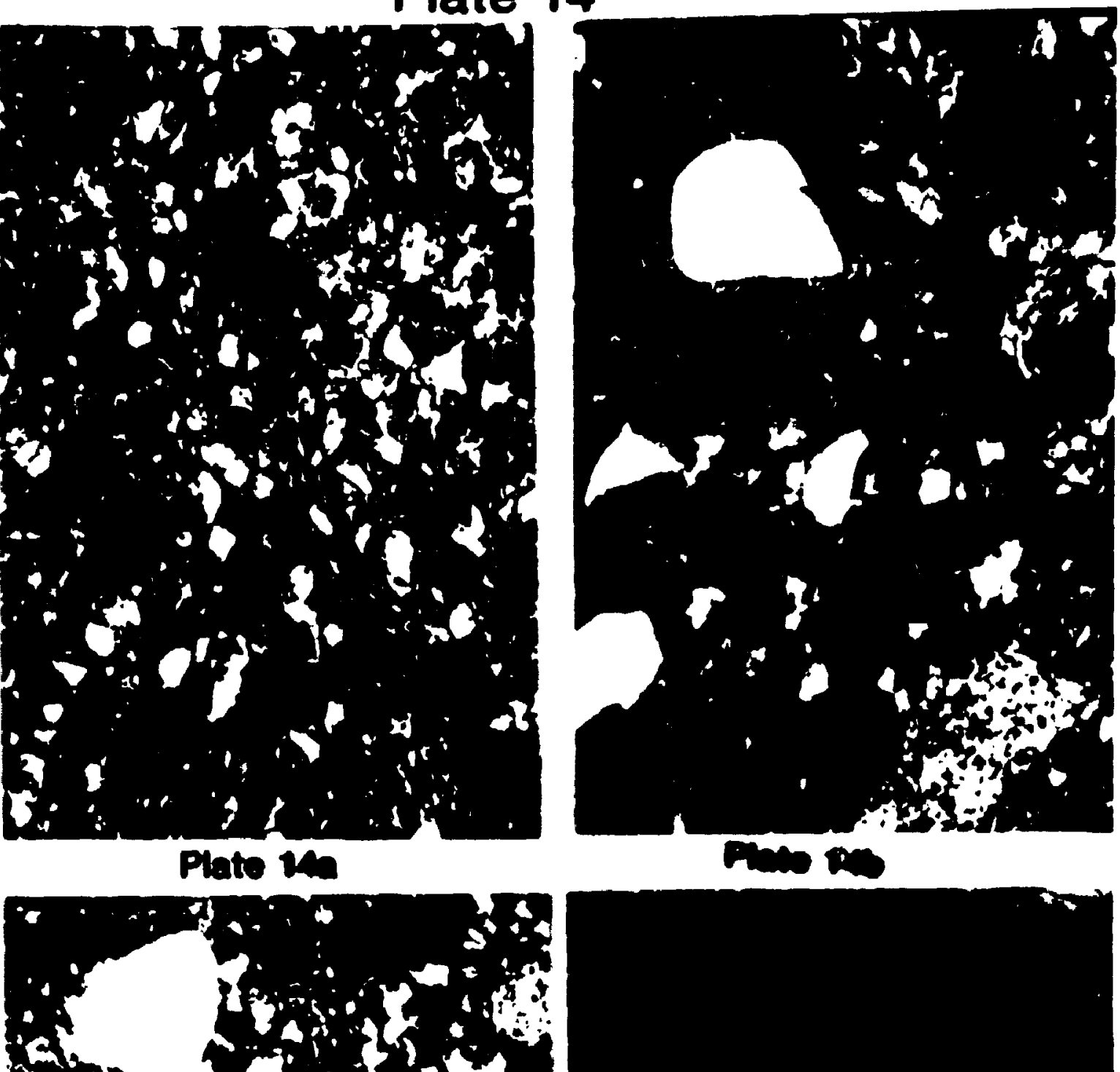

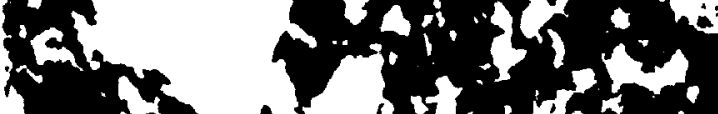

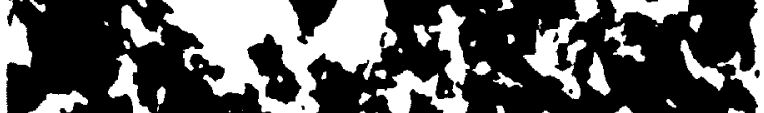

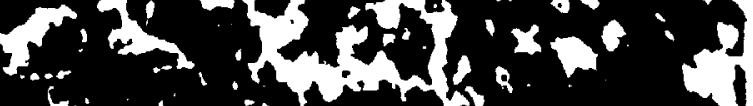

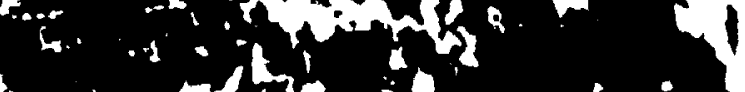

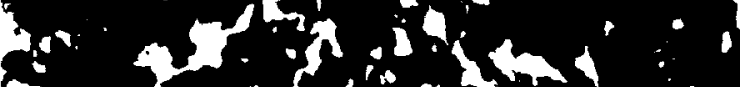

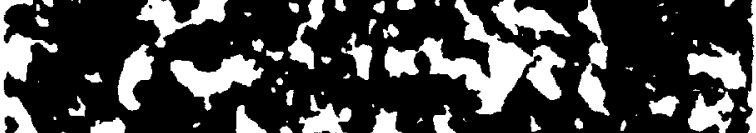

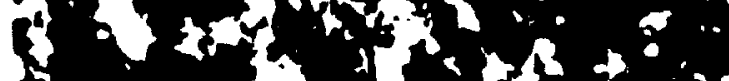

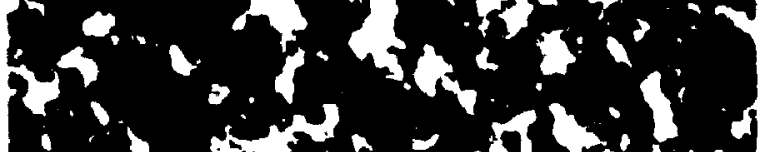

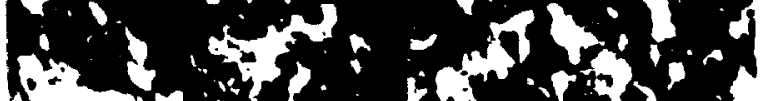
(1)

Plate 14c

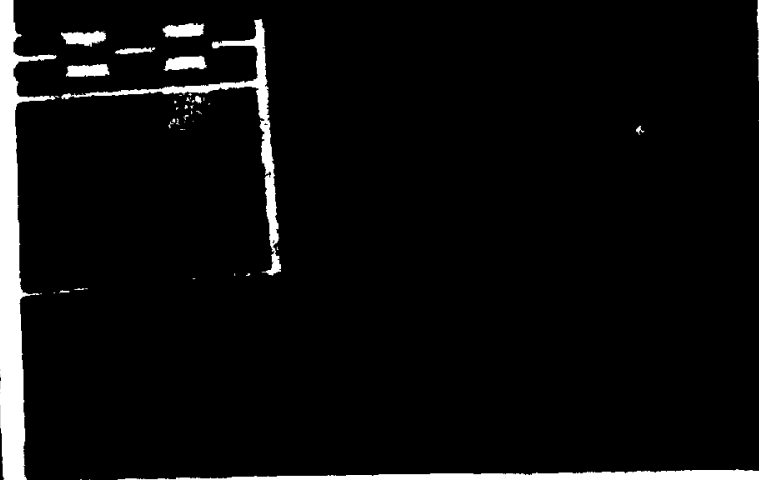



The Origin of Clastic Dykes

154

Plate 15. 
Plate 15a.

Sandstone dyke containing sightly displaced pillow fragments.

Plate 15b.

Laminations in a sandstone dyke. The laminations are subparallel to the paleohorizontal, inferred from bedding in overlying sandstone.

Plate 15c.

Contact between the upper sandstone and the pillowed flow showing continuity of sandstone in the dyke and the overlying bed. Compare with Figure 19.

Figuire 17. (First overleat)

Map of a sandstone dyke. Dashed line at base of left column fits on similar line at the top of right column. Laminations noted in the field were added to the map.

Figure 18. (Second overleaf)

Map of a sandstone dyke. This dyke is located just south of the large mafic multiple dyke in Figure 9. The left column fits directly on top of the right column. Figure 19 is the continuation of the same dyke 3 metres above the end of the exposure of the right column. Note that near the top of the right column, the sandstone dyke branches out, filling radial cooling fractures in two pillows.

Figure 19.

Contact between the upper sandstone and the pillowed flow showing continuity of sandstone in the dyke and the overlying bed. 


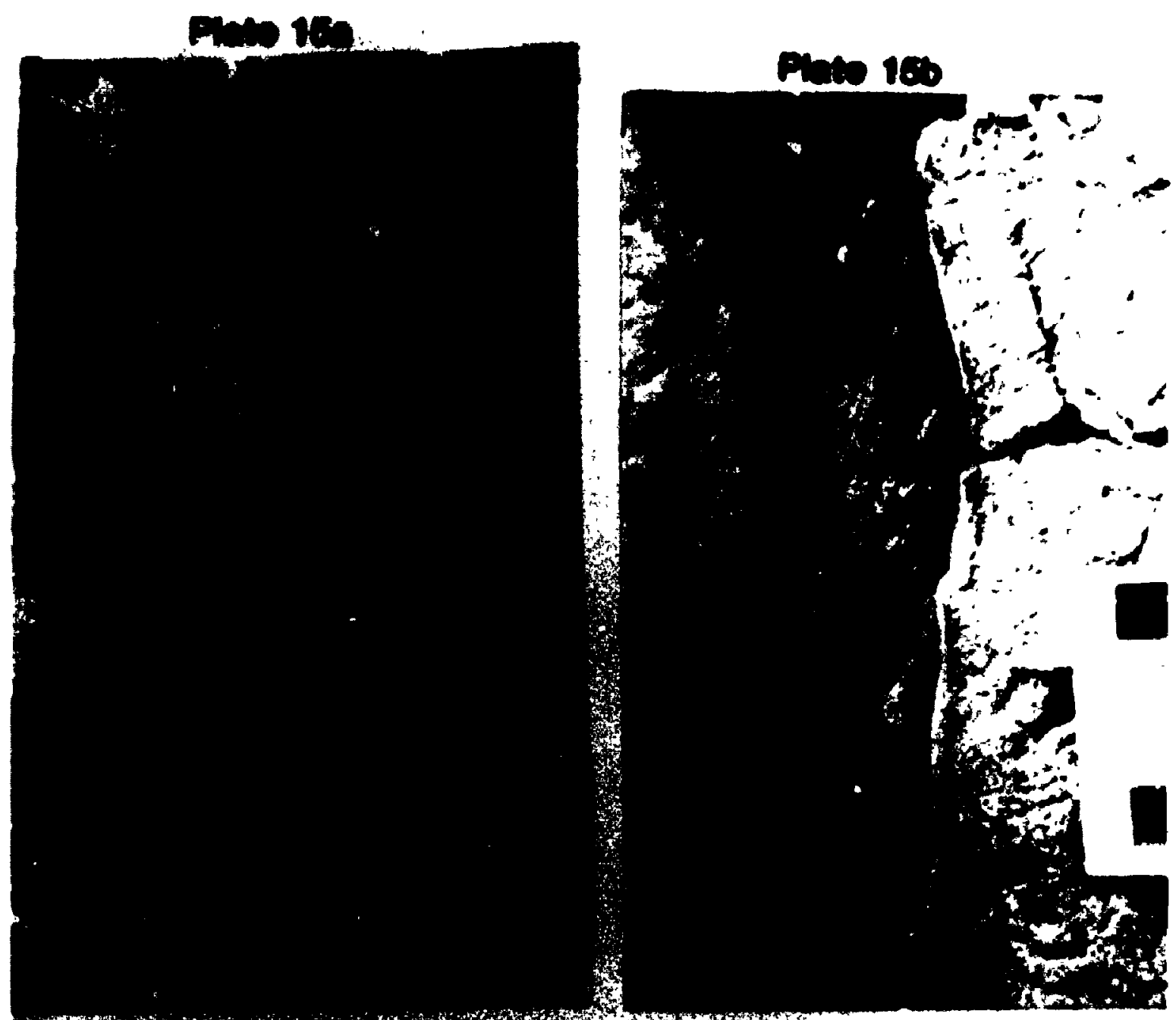

7 why

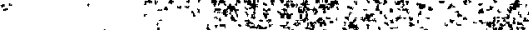

$\mathrm{N}^{2}, \mathrm{n}$

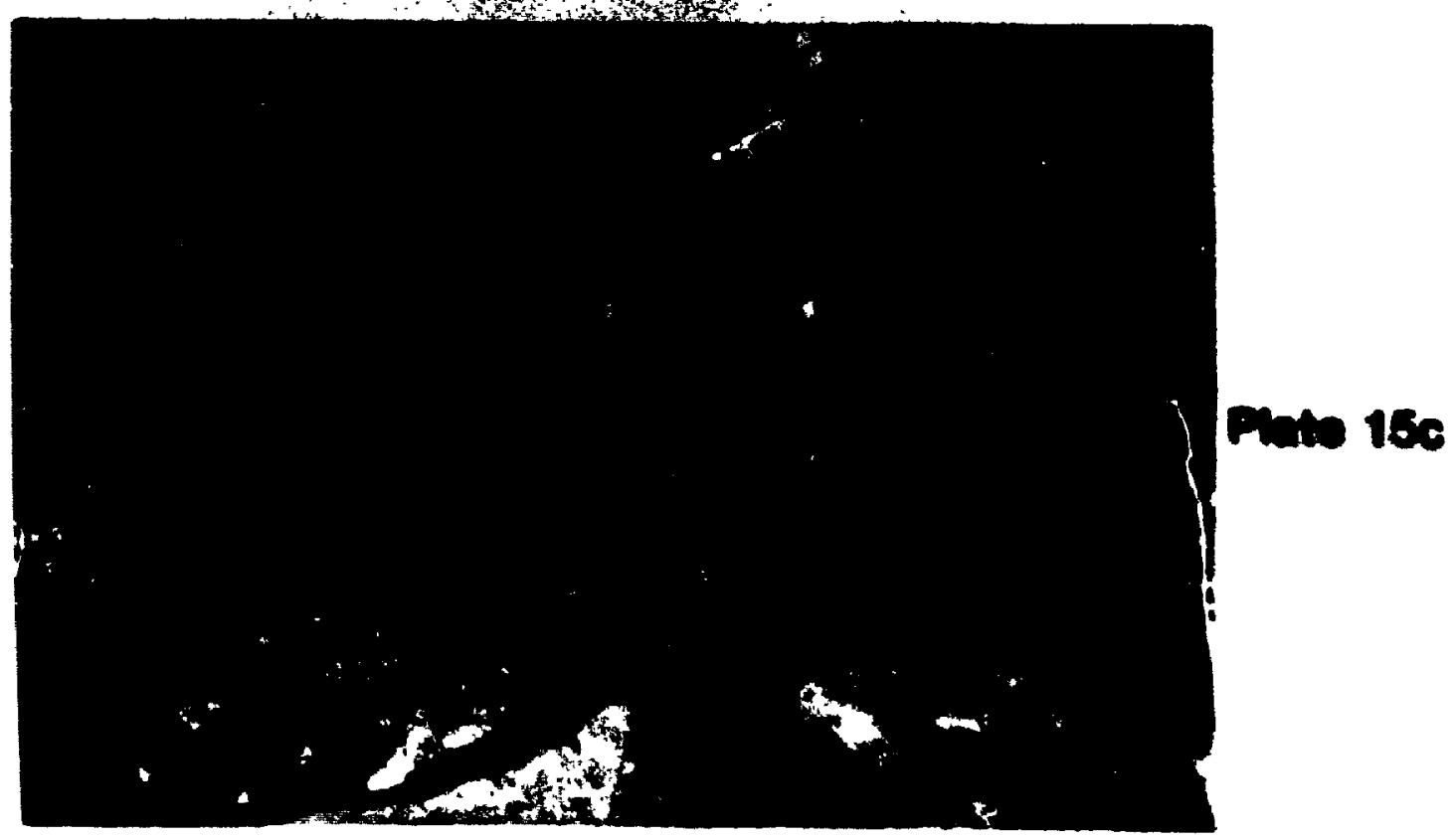



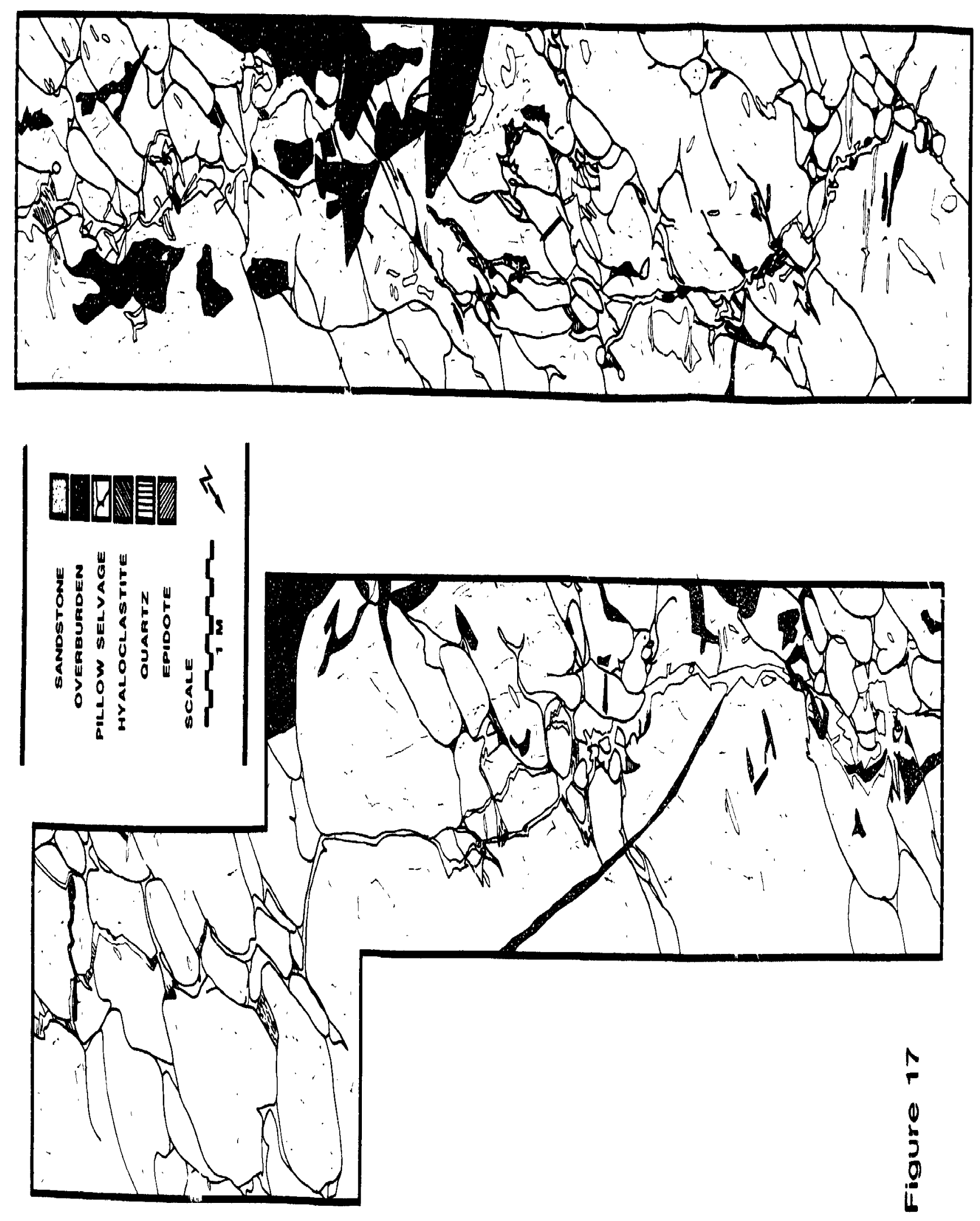


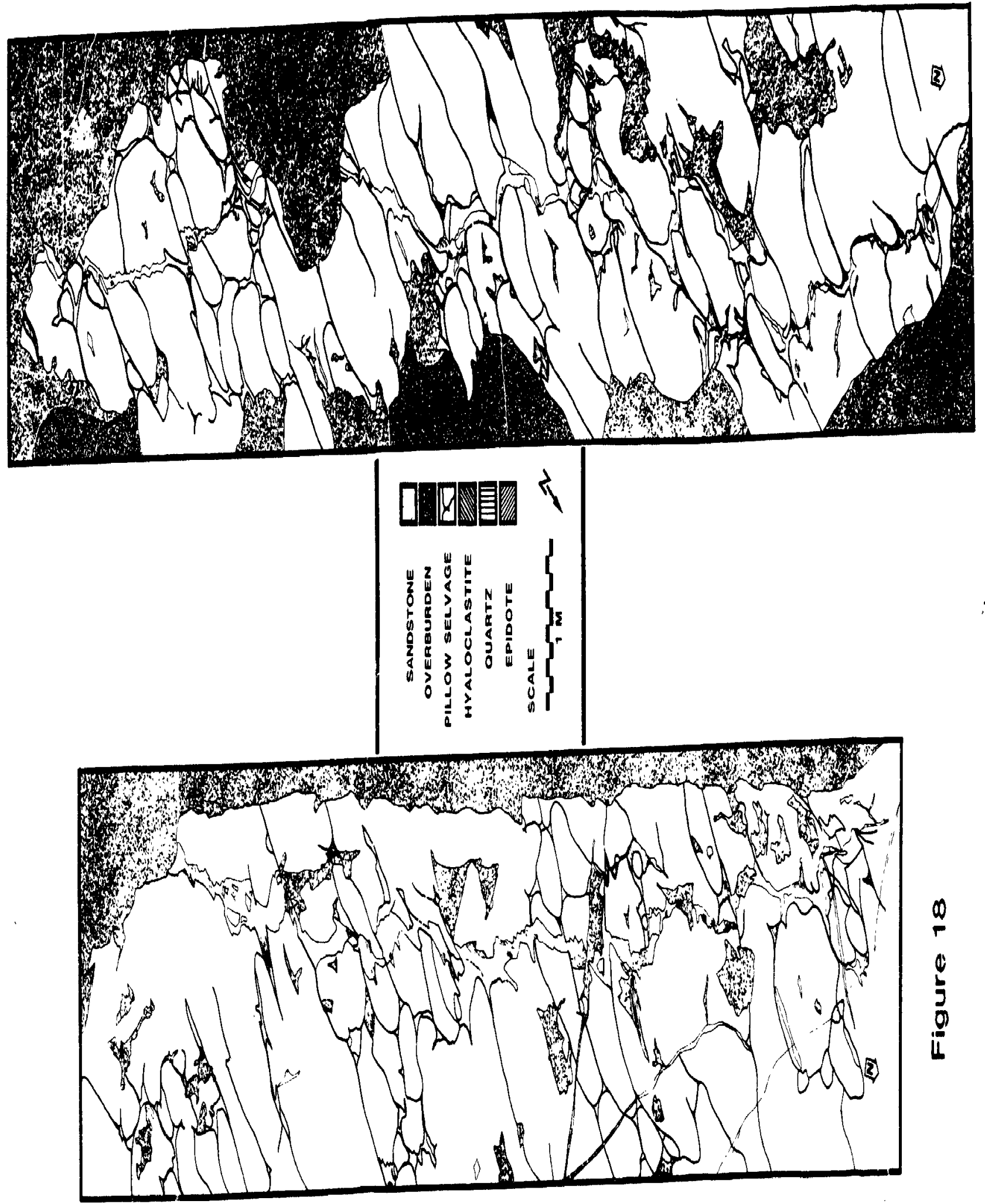



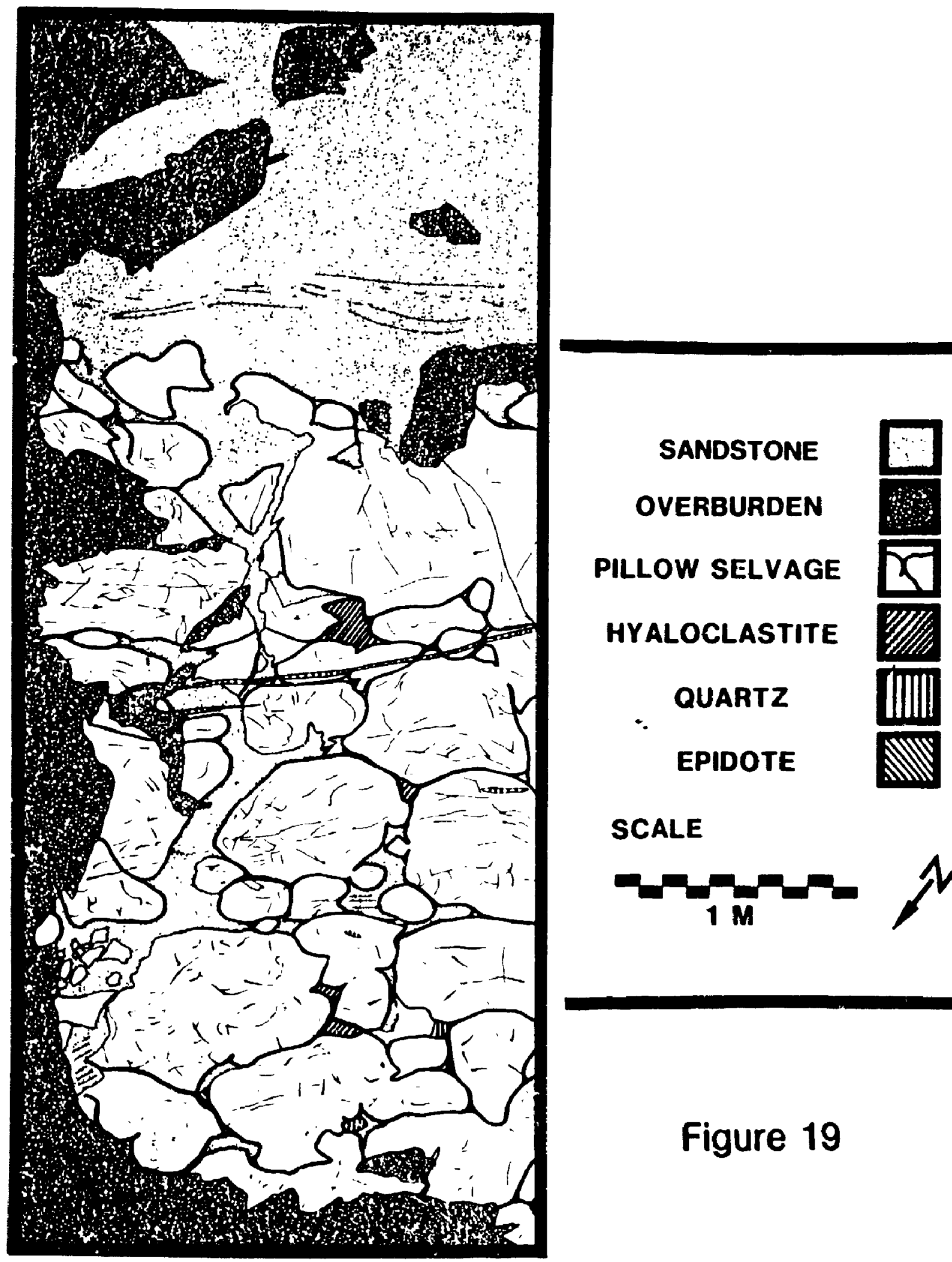

SCALE

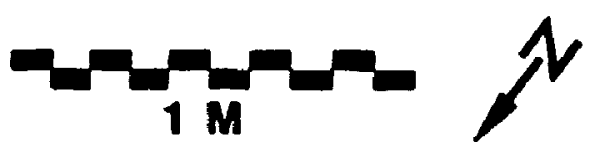

Figure 19 


\section{Dyke Formation Model}

In a tectonically unstable environment such as an active volcanic edifice, many mechanisms could create large frectures in a pillowed now. However, several features of the dykes described here serve to limit the possibilities:

- termination of the fractures below the overhying sandstone.

- lateral restriction of dykes to a single composite unit of pillowed flows.

- zones of sand in the dykes show laminations subparallel to the paleohorizontal that prevailed at the time of lava extrusion.

The following model is proposed to accommodate all of these features.

During the first stage of this model, a massive amygdaloidal basalt flow capped by flow-top breccia was subaqueously extruded on top of a : and bed (Figure 20a). Sand was boiled into the water column: some was locally incorporated into the breccia, but most was rapidly deposited to form the massive sand blanket on top of the breccia. Soon after the lava had solidified, currents resulted in the deposition of more sand characterised by climbing ripples (Figure 20b). The hot flow underneath provided a source of chemically active fluids that may have locally caused partial cementation of this sand.

Additional volcanism resulted in extrusion of the composite unit of pillowed flows. Initially, the pillows were extruded onto the water-saturated sand, and the uncemented upper part of the sand was forcefully injected into pillow interstices and locally incorporated in pillow selvages. After the initial pulse of magma, pillow formation halted briefly, and epiclastic sedimentation resumed (Figure 20c). The time interval before the next phase of pillow formation was too brief to allow lithification of the sand deposits, and only isolated pockets were preserved.

Due to their high surface area, the pillows cooled and solidified rapidly. After volcanic activity subsided, deposition of sand by currents resumed (Figure $20 d$ ). Meanwhile, the underlying massive basalt flow had not yet solidified completely. This flow provided a zone of weakness to be exploited during lateral intrusion of a gabbroic 
Figure 20. 
Figure 20.

Model of Dyke formation.

a) Extrusion of massive lava flow (unpatterned) and flow-top breccia (random triangles) over a sand bed.

b) Deposition of sand above the massive flow.

c) Extrusion of pillows on top of lower sandstone, and deposition of the intercalated sand lenses.

d) Deposition of upper sand on top of pillows.

e) Fracturing and dyke emplacemant in response to upward doming due to intrusion of the sill.

f Resumption of sand deposition by normal currents. 

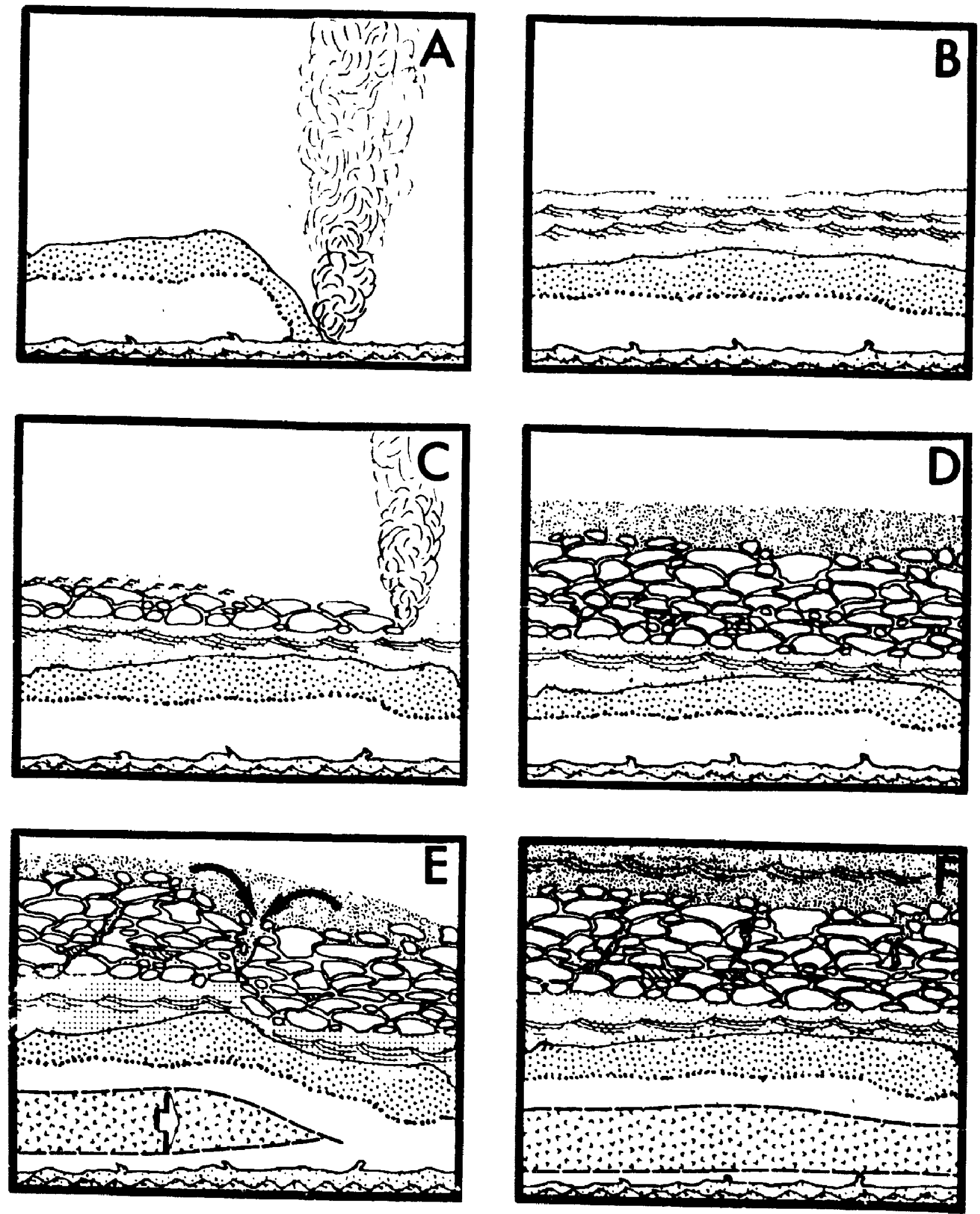
sill fed by a nearby oyke (Figure 200). As the gabbro intruded the basaltic flow, it differentially inflated the basalt and caused unoven uplitt of the overlying rigid pillow flow. Large fractures opened from the top of this how, and the overlying sand infiltrated these fractures. The initial rush of sand was responsible for the predominantly massive character of the sandstone dykes. The force of infilling resulted in both the flushing of sand into small cooling fractures in adjacent pillows, and the incorporation of some pillow fragments. After the initial pulse of sedimentation, a quieter phase allowed some sand to be resedimented into open and sheltered pockets away from the main part of the dykes. This phase was responsible for deposition of the locally larninated sediments (Figre 201). Minor earthquakes may have contributed to initiation of this settling.

\section{Conclusions}

The clastic dykes in the Giant Section are interpreted as sand infills of fractures that formed in the pillowed host flow as a result of intrusion of a gabbro sill into a massive, not yet fully solidified underlying flow. Athough this model is complex, it fits the available evidence, and it explains all of the features associated with the dykes. This model may have implications that are not restricted to the small area in the Giant Section from which it is derived. A sizeable proportion of the Upper Kam Group and other parts of the Yellowknife Volcanic Belt consist of gabbroic intrusions which appear to be synvolcanic. The accuracy with which the timing of gabbroic intrusion can be fixed in the example outlined here, is unusual for the Archean, where radiometric dating of mafic volcanic rocks is difficult, and the stratigraphy generally is tragmented. If clastic dykes can be located in comparable settings elsewhere in the Slave Province, the model could serve to strengthen the case for widespread synvolcanic gabbro dyke and sill emplacement. The model is applicable to studies of younger volcanic terranes as well. 
Aspler, L. B., and Donaldson, J. A. 1986. Penecontemporaneous sandstone dykes, Nanacho Basin (early Proterozolc, Northwest Territories): horizontal injection in vertical, tabular fissures. Canadian Journal of Earth Sciences, 23: 827-838.

Atkinson, D. J. 1989. Geology of the Western Plutonic Complex, Southwestern Slave Province. In Exploration Overview 1989 Northwest Territories, Mining, Exploration and Geological Investigations. Edited by C. E. Ellis. INAC, NAP Geology Division, Yellowknife NWT.

Ayres, L.D. 1983. Pyroclastic Rocks in Precambrian Greenstone-Belt Volcanoes. In Pyroclastic Volcanism and Deposits of Cenozoic Intermedlate to Felsic Volcanic Islands with Implications for Precambrian Greenstone-Belt Volcanoes. Edited by Ayres, L.D., Geological Association of Canada Short Course Notes Volume 2. 343365.

Bailey, G. 1987a. Stratigraphy of the Banting Group, Yellowknife Greenstone Belt, NWT. M.Sc. Thesis, Queen's University, Kingston, Ontario. 130 p.

Bailey, G. 1987b. Guide to the Shot Member of the Banting Group. In Yellowknife Guide Book: A Guide to the Geology of the Yellowknife Volcanic Belt and its bordering rocks. Euited by W.A. Padgham. Teological Association of Canada, Mineral Deposits Division. 81-88.

Baragar, W. R. A. 1966. Geochemistry of the Yellowknife Volcanic Rocks. Canadian Journal of Earth Sciences, 3: 9-30.

Baragar, W. R. A. 1975. Miscellaneous Data from Volcanic Belts at Yellowknife,Wolverine Lake, and James River, N.W.T. Geological Survey of Canada, Paper 75-1, Part A, 281-286.

Baragar, W. R. A., Plani, A. G., Pringle, G.J., and Schau, M. 1979. Diagenetic and Postgenetic Changes in the Composition of an Archean Pillow. Canadian Journal of Earth Sciences, 16: 2102-2121.

Barker, D. S. 1983. Igneous Rocks. Prentice-Hall, Inc. N.J., 417 p.

Boyle, R. W. 1961. The Geology, Geochemistry and Origin of the Gold Deposits of the Yellowknife District. Geological Survey of Canada, Memoir 310.

Brown, N. 1989. Structural Evolution of the Giant Shear Zone Complex. In Exploration Overview 1989 Northwest Territories, Mining, Exploration and Geological Investigations. Edited by C. E. Ellis. INAC, NAP Goology Division, Yellowknife NWT. 
Bullis, H. R., Pratico, V. V., and Webb, D. R. 1987. The Con Mine.

In Yellowknife Guide Book: A Guide to the Geology of the Yellowknife Volcanic Belt and its Bordering Rocks. Edited by W. A. Padgham. Goological Association of Canada, Mineral Deposits Division, 175-123.

Campbell, N. 1948. The West Bay Fault. In Structural Geology of Canadian Ore Deposits, Canadian Institute of Mining and Metallurgy, Jubilee Volume, 244-259.

Carey, S., and Sigurdsson, H. 1984. A Model of Volcanogenic Sedimentation in Marginal Basins. In Marginal Basin Geology, Volcanic and Associated Sedimentary and Tectonic Processes in Modern and Ancient Marginal Basins. Edited by B.P. Kokelaar and Howells. Blackwell Scientific Publications, Oxford, 37-55.

Cumming, G. L., and Tsong, F. 1975. Variations in the Isotopic Composition of Volatilized Lead and the Age of the Western Granodiorite, Yellowknife, NWT. Canadian Journal of Earth Sciences, 12: 558-573.

Cunningham, M. 1984. Petrochemistry of the Yellowknife Greenstone Belt, Yellowknite, N.W.T. Unpublished M.Sc. thesis, University of Alberta, Edmonton, Alberta.

Dionne, J. C., and Shilts, W. W. 1974. A Pleistocene Clastic Dyke, Upper Chadiere Valley, Quebec. Canadian Journal of Earth Sciences, 11: 1594-1605.

Donaldson, J. A., Falck, H., Potts, G., Donaldson, B., and Padgham, W.A. 1987. Enhancement of Outcrops of Archean Volcanic and Sedimentary Rocks in the Giant Section Near Yellowknife, NWT. Geological Association of Canada, Summer Meeting Yellowknife (Abstract)

Easton, R. M. 1984. Compilation of Geochronological Data for the Yellowknife Greenstone Belt $(85 \mathrm{~J} / 8,85 \mathrm{~J} / 9)$ and Vicinity, District of Mackenzie, NWT. In Exploration Overview 1987 Northwest Territories, Mining, Exploration and Geological Investigations. Edited by J. A. Brophy. INAC, NAP Geology Division, Yellowknife NWT., 1-20.

Easton, R. M., and Jackson, V. 1981. Geology of the Walsh Lake Area, NTS 85J/9. INAC, NAP Geology Division, Yellowknife NWT. EGS 1982-5.

Einsele, F. 1985. Basaltic-Sill-Sediment Complexes in Young Spreading Centres: Genesis and Significance. Geology, 13: 249-252.

Fiala, F. 1974. Some Notes on the Problem of Spilites. In Spilites and Spilitic Rocks. Edited by G. C. Anstitz. Springer Verlag, Berlin, 9-22. 
Fisher, R. V. 1982. Debris Flows and Latıars. In Pyroclastic Volcanism and Deposits of Cenozoic intermediate to Folsic Voicanic Islands with Implications for Precambrian Greenstone-Belt Volcanoes. Edited by L. D. Ayres. Geological Association of Canada Short Ciourse Notes, 2: 136-220.

Fisher, A. V. 1984. Submarine Volcaniclastic Rocks. In Marginal Basin Geology, Volcanic and Associated Sedimentary and Tectonic Processes in Modern and Ancient Marginal Basins. Edited by B. P. Kokelaar, and Howells. Blackwell Scientific Publications, Oxford, 5-27.

Franklin, J. M. 1986. Volcanic-associated massive sulphide deposits-an update. In Irish association for Economic Geology, Geology and Genesis of mineral deposits in Irelanj. Edited by C. J. Andrew, E. W. A. Crowe, S. Finlay, W. M. Rennell, and J. F. Pyne, 49-69.

Freundt, A., and Schmincke, H. U. 1985. Lithic-Enriched Segregation Bodies in Pyroclastic Flow Deposits of Laacher See Volcano (East Eifel, Germany). Journal of Volcanology and Geothermal Research, 25: 193-224.

Furnes, H. 1973. Variolitic Structure in Ordovician pillow lava and its possible significance as an environmental indicator. Geology, 1: 27-30.

Frith, R. A. 1978. Tectonics and Metamorphism Along the Southern Boundary Between the Bear and Slave Structural Provinces. Ir Metamorphism in the Canadian Shield. Edited by J. A. Fraser, and W. W. Heywood. Geological Survey of Canada, Paper 78-10, 103-114.

Fyson, W. K. 1982. Complex Evolution of Folds and Cleavages in Archean Rocks, Yellowknife, NWT. Canadian Journal of Earth Sciences, 10: 900-919.

Fyson, W. K. 1987. Guide to Structures in Metasedimentary Rocks Around Yellowknife. In Yellowknife Guide Book: A Guide to the Geology of the Yellowknife Volcanic Belt and its Bordering Rocks. Edited by W. A. Padgham. Geological Association of Canada, Mineral Deposits Division. 89-104.

Fyson, W. K., and Helmstaedt, H. 1988. Structural patterns and tectonic evolution of supracrustal domains in the Archean Slave province, Canada. Canadian Journal of Earth Sciences, 25: 301-315.

Green, D. C., Baadsgaard, H., and Cumming, G. L. 1968. Geochronology of the Yellowknife area, Northwest Territories, Canada. Canadian Journal of Earth Sciences, 5: 725-735.

Green, D. C., and Baadsgaard H. 1971. Temporal Evolution and Petrogenesis of an Archean Crustal Segment at Yellowknife. NWT. Journal of Petrology, 12: 177-217. 
Goodwin. A.M., 1987. Geochemistry of Slave Province Volcanic Rocks:

Yellowknife Belt. Contributions to the Geology of the Northwest Territories, 3: 13-26.

Gudmundsson, A. 1984. Formation of Dykes, Feeder-Dykes and the Intrusion of Dykes from Magma Chambers. Bulletin of Volcanology, 47: 537-550.

Helmstaedt, H., Goodwin, J. A., Patterson, J. G., and King, J. E. 1979.

Preliminary Geological Map, Southern End of Yellowknife Greenstone Belt. INAC, NAP Geology Division, Yellowknifo NWT., EGS-1979-9.

Helmstaedt, H., King, J., and Boodle. A. 1980. Geology of the Banting and Walsh Lakes Map Area, NTS $85 \mathrm{~J} / 9$. Department of Indian and Northern Affairs, EGS-1980

Helmstaedt, H., King J. E., Goodwin, J. A., and Patterson, J. G. 1981. Geology of the Southwest End of the Yellowknife Groenstone Belt. In Proceedings of the Gold Workshop, Yellowknife NWT. Edited by R. D. Morton. Yellowknife Goldworkshop Committee, 232-249.

Helmstaedt, H., Padgham, W. A., and Brophy, J. A. 1986. Multiple Dikgs in the Lower Kam Group, Yellowknife Greenstone Belt: Evidence for Seafloor Spreading? Geology, 14: 562-566.

Helmstaedt, H., and Padgham, W. A. 1986a. A New Look at the Stratigrapliy of the Yellowknife Supergroup at Yellowknife, N.W.T. - Implications for the Age of Gold Bearing Shear Zones and Archean Basin Evolution. Canadian Journal of $E_{\text {: }}$ th Sciences, 23: $454-475$

Helmstaedt, H., and Padgham, W. A. 1986b. Stratigraphic and Structural Setting of the Gold-Bearing Shear Zones in the Yellowknife Greenstone Belt. In Gold in the Western Shield. Edited by L. A. Clark. Canadian Institute of Mining, Special Volume 38, 322-34.5.

Helmstaedt, H., and Bailey, G. 1987. Problems of Structural Geology in the Yellowknife Greenstone Belt. In Yellowknife Guide Book: A Guide to the Geology of the Yellowknife Volcanic Belt and its Bordering Rocks. Edited by W. A. Padgham. Geological Association of Canada, Mineral Deposits Division. 33-39.

Henderson, J. B. 1970. Stratigraphy of the Yellowknife Supergroup, Yellowknife Say - Prosperous Lake Area, District of Mackenzie. Geological Survey of Canada, Paper 70-26, $12 \mathrm{p}$.

Henderson, J. B. 1972. Sedimentology of Archean Turbidites at Yellowknife, Northwest Territories. Canadian Journal of Earth Sciences, 9: 682-902. 
Hendcrson, J. B. 1985. Geology of the Yellowknife-Hearne Lake Area, District of Mackenzie: A Segment Across an Archean Basin. Geological Survey oí Canada, Memoir 414, $135 \mathrm{p}$.

Henderson, J. B. 1987. The Bunwash Formaticn at Yellowknife, Northwest Territories. In Yellowknife Guide Book: A Guide to the Giology of the Yellowknife Volcanic Belt and its Bordering Rocks. Edited by W. A. Padgham. Gaological Association of Canada, Mineral Deposits Division. 21-31.

Henderson, J. F. 1938. Beaulieu Piver Area, Northwest Territories. Geological Survey of Canada, Paper 38-1.

Henderson, J. F., and Brown, I. C. 1966. Geology and Structure of the Yellowknife Greenstone Belt, District of Mackenzie. Geological Survey of Canada, Bulletin 141. $87 \mathrm{p}$.

Hencerson, J. F., and Brown, I. C. 1967. Geology of the Yellowknife Greenstone Belt, District of Mackenzie. Geological Survey of Canada, Map 1193A.

Hurdle, E. 1984. Geology of a Volcanic Pile at Clan Lake. In Contributions to the Geology of the Northwest Territories. Edited by J. R. Brophy. INAC, NAP Geology Division, Yellowknife NWT., EGS-1984-5.

Hurdle, E. 1987. Guide to the Clan Lake Volcanic Pile. In Yellowknife Guide

- Book: A Guide to the Geology of the Yellowknife Volcanic Belt and Its Bordering Rocks. Edited by W. A. Padgham. Geological Association of Canada, Mineral Deposits Division, 123-134.

Isachsen, C. E., Bowring, S. A., and Padgham, W. A. 1989. U-Pb Zircon Geochronology of the Yellowknife Volcanic Belt, N.W.T., Canada: New Constraints on the timing and duration of Greenstone Belt Magmatism. (In press.)

Jenner, G. A., Fryer, B. J., and McLennan, S. M. 1981. Geochemistry of the Archean Yellowknife Supergroup. Geochimica et Cosmochimica Acta, 45: 1111-1129.

Jolliffe, A. W. 1936. Preliminary Report, Yellowknite River Area, Northwest Territories. Geological Survey of Canada, Paper 38-21, 41 p.

Jolliffe, A. W. 1942. Prosperous Lake, District of Mackenzie, Northwest Territories. Geological Survey of Canada, Map 868A.

Jolliffe, A. W. 1946. Yellowknife Bay, District of Mackenzie, Northwest Territories. Geological Survey of Canada, Maij 709A. 

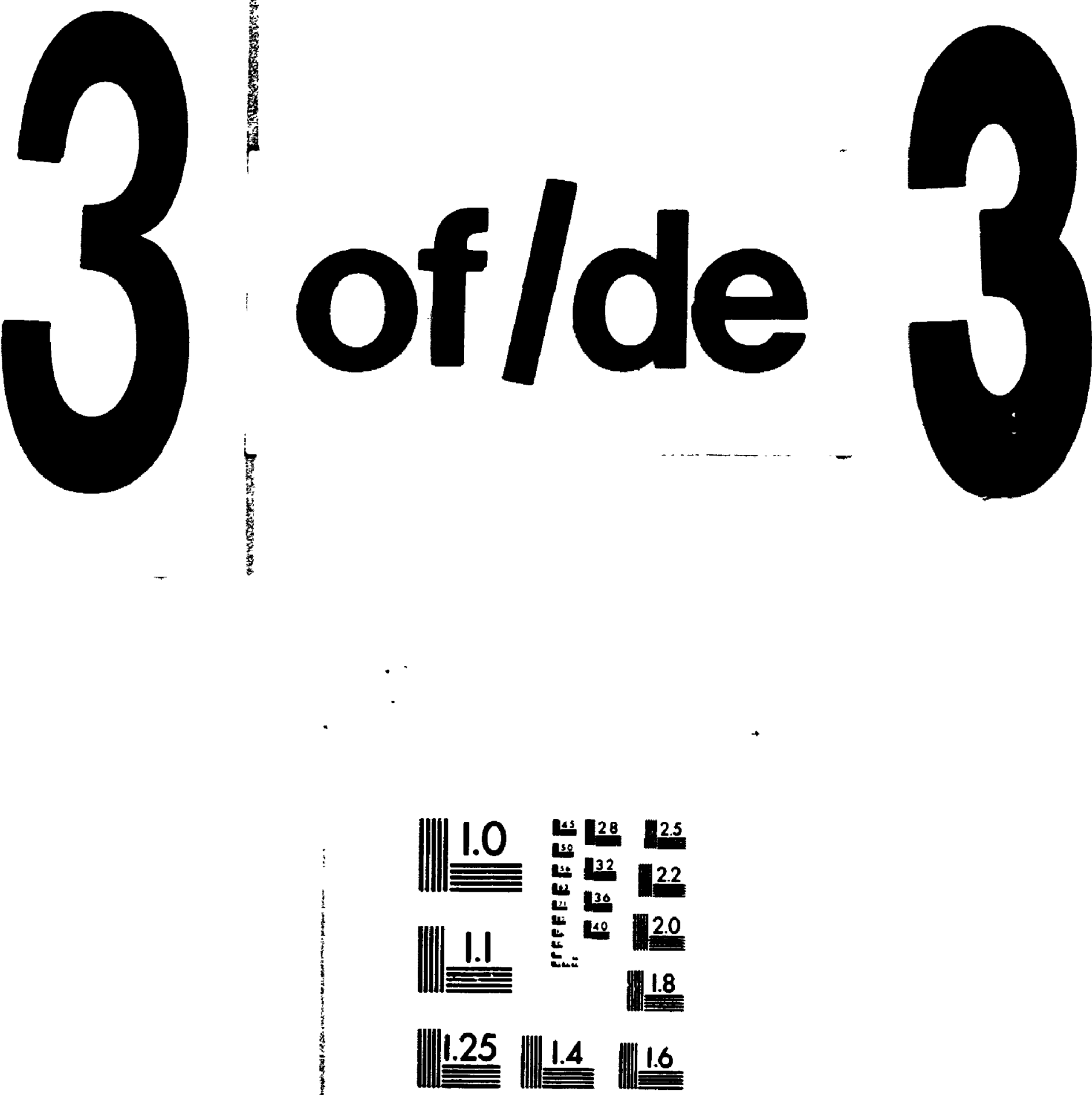

MICROCOPY RESOLUTION TEST CHART

NATIONAL BUAEAU OF STAMDARDS

STANDARD REFERENCE MATEPIAL 1010 (ANSI and ISO TEST CHART No 2). 
Jones, J. G. 1969. Pillow Lavas as Depth Indicators. American Journal of Science, 267: 181.

Kawachi, Y., and Pringle, I. J. 1988. Multiplerind structure in pillow lava as an indicator of shallow water. Bulletin of Volcanology, 50: 161-168.

Kokelaar, P. 1986. Magma-Water Interactions in Subaqueous and Emergent Basaltic Volcanism. Bulletin of Volcanology, 48: 275-289.

Kusky, T. M. 1987. Comment on "Multiple Dikes in the Lower Kam Group,Yellowknile Greenstone Belt: Evidence for Archean Seafloor Spreading?" Geology, 15: 280-281.

Kusky, T. M. 1989. Accretion of the Archean Slave province. Geology, 17: 63-67.

Lajoie, J. 1984. Volcaniclastic Rocks. In Facies Models, Second Edition. Edited by R. Walker. Geoscience Canada Reprint Series, Aiısworth Press Ltd. Kitchener, Ont. 39-52.

Lambert, M. B., 1984. Evolution of the Cameron and Beaulieu River Volcanic Belts, Slave Province, NWT: Current Activities Forum 1984, Program with Abstracts. Geological Survey of Canada, Paper 84-8, p. 12.

Lambert, R. St. J., and Cunningham, M. 1983. Rb-Sr Geochronology of the Yellowknife Archean, NWT. Geological Association of Canada, Program with Abstracts, 9: 81.

McPhie, J. 1986. Primary and redeposited Facies from a Large-Magnitude, Rhyolitic, Phreatomagmatic Eruption: Cana Creek Tuff, Late Carboniferous, Australia. Journal of Volcanology and Geothermal Research, 28, 319-350.

Meintzer, R. E., and Wise, M.A. 1987. Granitoids and Pegmatites. In Yellowknife Guide Book: A Guide to the Geology of the Yellowknife Volcanic Belt and its bordering rocks. Edited by W. A. Padgham. Geological Association o! Canada, Mineral Deposits Division, 123-134.

Middleton, G. V., and Hampton, M.A. 1973. Sediment Gravity Flows. In Turbidites and DeepWater Sedimentation. Edited by G. V. Middleton, and A. H. Bouma. Society of Economic Paleontologists and Mineralogists, Short Course Lecture Notes.

Miyashiro, A. 1974. Volcanic Rock Series in Island Arcs and Active Continental Margins. American Journal of Science, 274: 321335. 
Moore, J. G., and Schilling, J. G. 1973. Vesicles, water and sulphur in Reykjane Ridge basalt. Contributions to Mineral Petrology, 41: 105.

Nikic, Z., Baadsgaard, H., Folinsbee, R. E., Krupicka, J., Leoch, A. P., and Sasaki, A. 1980. Boulders from the Basement, the Tr-ce of an Ancient Crust. Goological Society of America, Special Paper 182, 169-175.

Padgham, W. A. 1980. An Archean Ignimbrite at Yellowknife and its Relationship to the Kam Formation Basalts. Precambrian Research, 21: 99-113.

Padgham. W.A. 1987a Yellowknife Guide Book, A guide to the geology of the Yellowknite Volcanic belt and its bordering rocks. Mineral Deposits Division, Geological Association of Canada. p.210.

Padgham, W. A. 1987b. The Yellowknife Volcanic Belt: Setting and Stratigraphy. In Yellowknife Guide Book: A Guide to the Geology of the Yellowknife Volcanic Belt and its bordering rocks. Edited by W. A. Padgham. Geological Association of Canada, Mineral Deposits Division, 11-21.

Padgham, W. A. 1987c. Guide to Parts of the Crestaurum, Townsite and Yellowknife Bay Formations and the Banting Group. In Yellowknife Guide Book: A Guide to the Geology of the Yellowknife Volcanic Belt and its Bcrdering Rock';. Edited by W. A. Padgham. Geological Association of Canada, Mineral Deposits Division, 55-80.

Pelletier, K. S., and Wahlroth, J. M. 1986. Geology of the Southwestern Yellowknife Bay Area, parts of NTS $85 \mathrm{~J} / 7,85 \mathrm{~J} / 8$. INAC, NAP Geology Division, Yellowknife NWT., EGS- 1986-12.

Pettijohn, F. J. 1970. The Canadian Shield-a status report, 1970. In Symposium on basins and geosynclines of the Canadian Shield. Edited by A. J. Baer. Goological Survey of Canada, Paper 70-40, 239-255.

Potts, G. W. 1988. Pillow Structure of the Yellorex Flows Near Yellowknife, Northwest Territories. Unpublished B.Sc. Thesis Carleton L'niversity, 50 p.

Ramsay, C. R., and Kamenini, D.C. 1977. Petrology and Evolution of an Archean Metamorphic Aureole in the Slave Craton, Canada. Journal of Petrology, 18: 460 486.

Relf, C., and Nicolson, D. C. 1986. Geology of the West Mirage Islands, NWT, parts of NTS 85 J/7,85 J/8. INAC, NAP Geology Division, Yellowknife NWT. EGS-1986-5. 
Roach, D., and Fyson, W. K. 1988. A Preliminary Report on the Stratigraphy and Structure of Metasedimentary-Metavolcanic Sequence at Beniah Lake, Slave Structural Province, NWT. In Exploration Overview 1988 Northwest Territories, Mining, Exploration and Geological Investigations. INAC, NAP Geology Division, Yellowknife NWT.

Ross, G. M. 1986. Eruptive style and Construction of Shallow Marine Mafic Cones in the Narakay Volcanic Complex (Proterozoic. Hornby Bay Group, Northwest Territories, Canada). Journel of Volcanology and Geothermal Research. 27: 265-297.

Sigurdsson, H. 1962. Volcanogenic Sodiments in Island Arcs. In Pyroclastic Volcanism and Deposits of Cenozoic Intermediate to Felsic Volcanic Islands with Implications for Precambrian Greenstone-Belt Volcanoes. Edited by L. D. Ayres. Geological Association of Canada Short Courso Notes, 2: 221-293.

Sparks, R. S. J. 1975. Grain size variations in ignimbrites and implications for the transport of pyroclastic flows. Sedimentology, 13: 147-188.

Sparks, R. S. J., and Walker, G. P. L. 1978. The Significance of Vitric-Enriched Air-Fall Ashes Associated with Crystal-Enriched Ignimbrites. Journal of Volcanology and Geothermal Research, 2: 329-341.

Stockwell, C. H. 1932. Great Slave Lake - Coppermine River Area, Northwest Territories. Geological Survey of Canada, Summary Report 1932, Part C, 37C-63C.

Thompson, P. H. 1978. Archean Regional Metamorphism in the Slave Structural Province - a Now Perspective of Some Old Rocks. In Metamorphism in the Canadian Shield. Edited by P. H. Thompson, W. W. Fraser, and J. A. Heywood. Cieological Survey of Canada, Paper 78-10, 85-102.

Thorpe, R. I. 1971. Comments on rock ages in the Yellowknife area, District of Mackenzie. Geological Survey of Canada, Paper 71-1B, 76-79.

Vallance, T.G. 1974. Spilitic Degradation of a Tholeiitic Basalt. Journal of Petrology, 15, 79-96.

Wanless, R. K. 1970. Isotopic Age Map of Canada. Geological Survey of Canada, Map 1256A.

Webb, D. R. 1987. Evidence of large-scale deformation of the ore zones at the Con Mine. In Yellowknife Guide Book: A Guide to the Geology of the Yellowknife Volcanic Belt and its bordering rocks. Edited by W. A. Padgham. Goological Association of Canada, Mineral Deposits Division, 175-190. 
Wright, J. V., Smith, A. L, and Self, S. 1980. A working Terminology of Pyroclastic Deposits. Journal of Volcanology and Geothermal Research, 8: 315-336.

Yamada, E. 1984. Subaqueous Pyroclastic Flows: Their Development and Their Deposits. In Marginal Basin Goology, Volcanic and Associated Sedimentary and Tectonic Processes in Modern and Ancient Marginal Basins. Edited by B. P. Kokelaar and Howells. Blackwell Scientific Publications, Oxford, 29-36. 



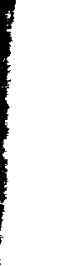
$\begin{array}{llll}1 & 1 & 1\end{array}$

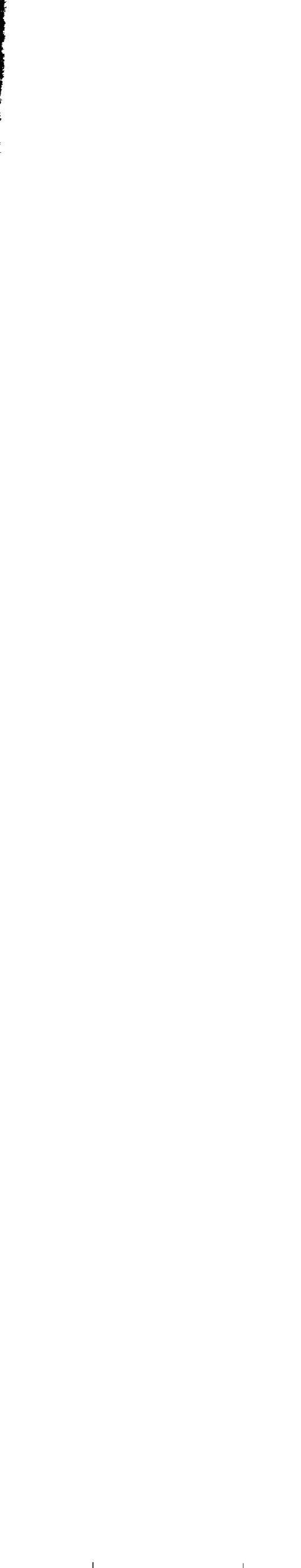


Appendix I Figure. 
Appendix I Figure.

Location map of Geochemical Samples. 


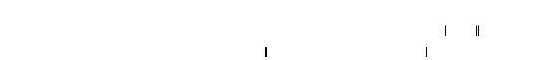




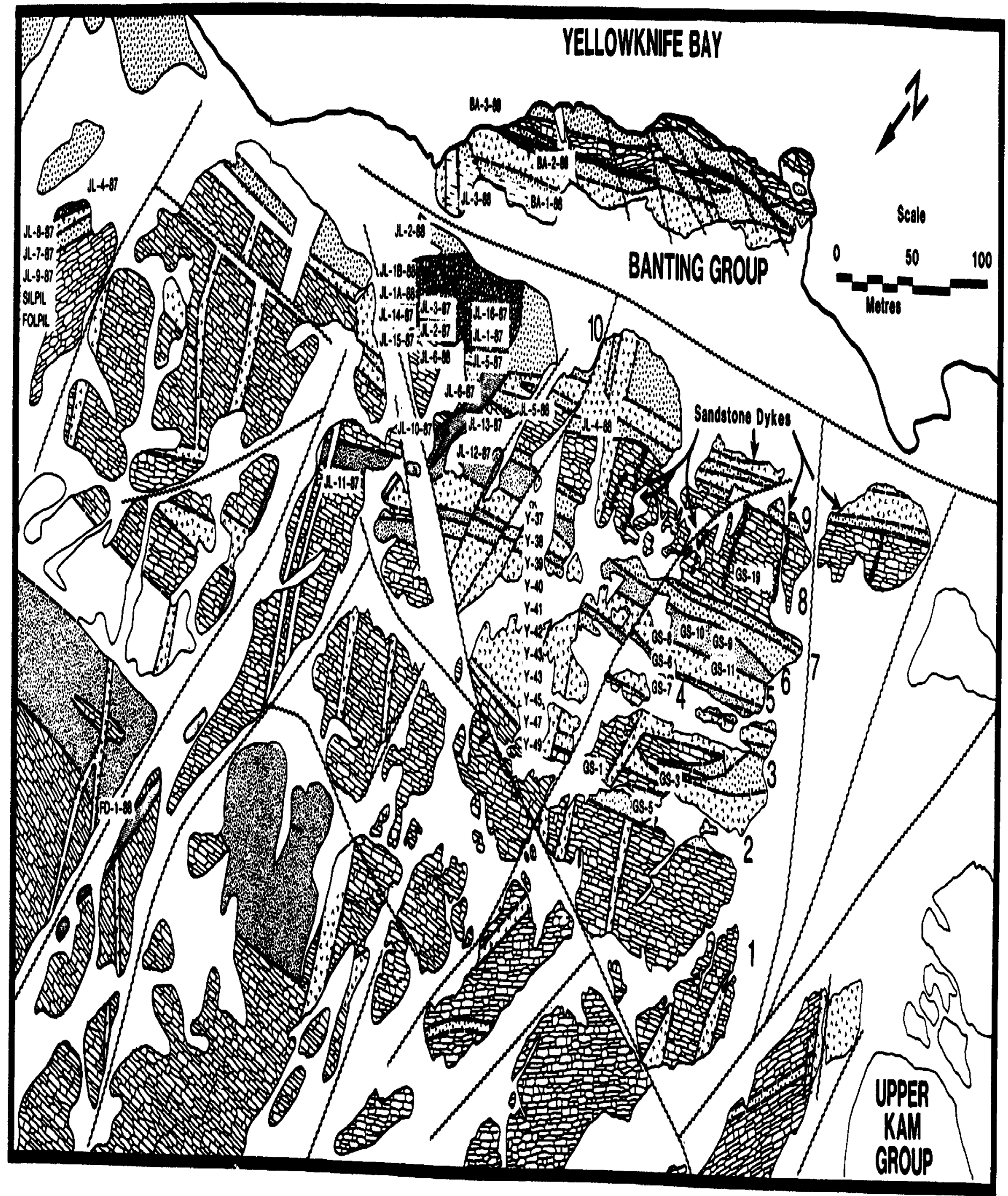




\section{SAMPLE DESCRIPTION LOCATION}

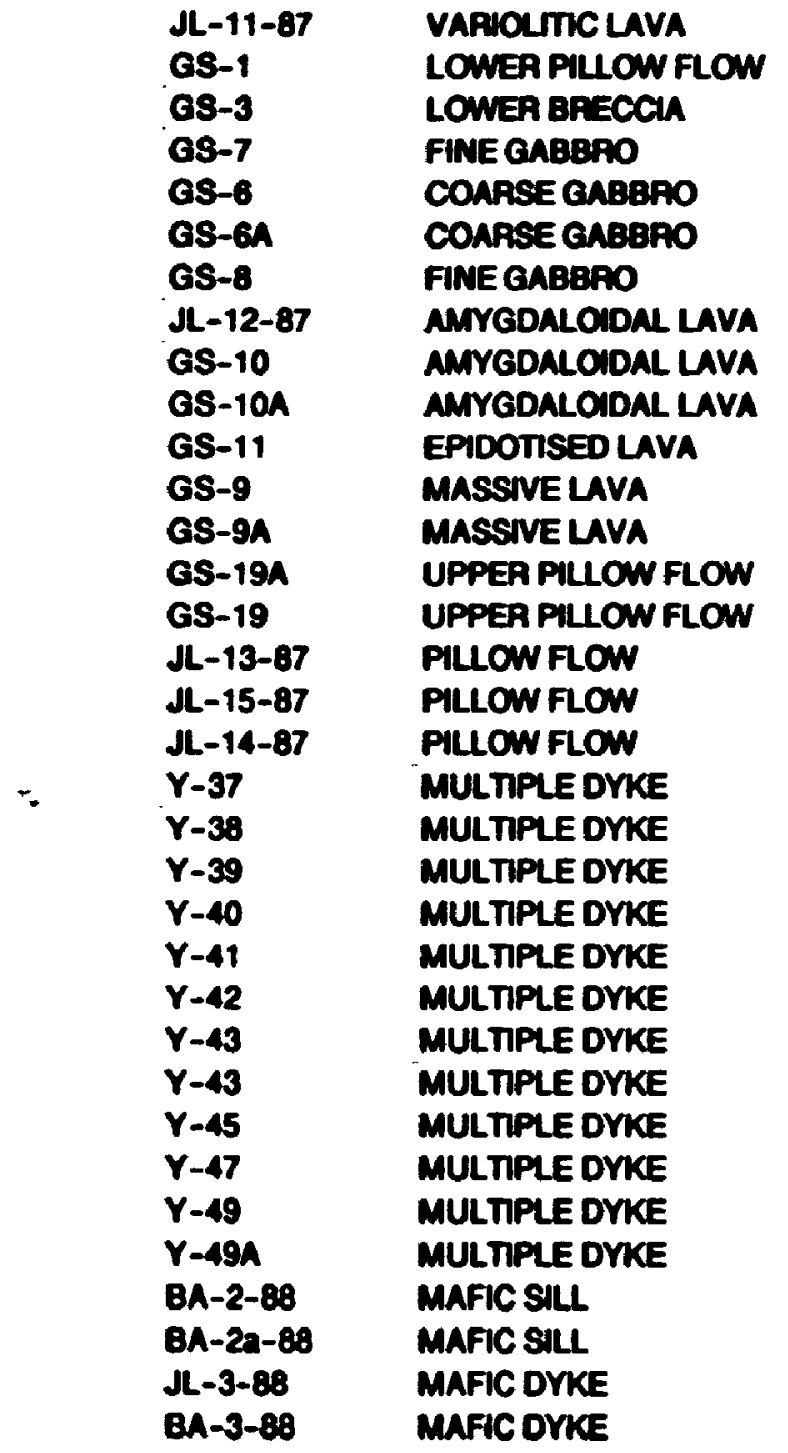

YELLOREX FLOWS, $40 \mathrm{~m}$ below Jackson Lake Contact 45 FLOW, above Bode member 15 Flow, above Bode member UPPER KAM GROUP, beas of the sill UPPEA KAM GPOUP, middle of the sill UPPER KAM GROUP, middle of the sill UPPER KAM GROUP, upper sill UPPER KAM GAOUP, $40 \mathrm{~m}$ bellow Jackson Lake Contact UPPER KAM GROUP, abowe 45 Flow UPPER KAM GROUP, above 15 Flow UPPER KAM GROUP, sillmow contact UUPER KAM GROUP, above is Flow UUPER KAM GROUP, sbove is Flow UPPER KAM GROUP. clastic dyke flow UPPER KAM GROUR, clastic dyke flow UPPEA KAM GROUP, $20 \mathrm{~m}$ below Jackson Lake Contact UPPER KAM GROUP, $1 \mathrm{~m}$ below Jackson Lake Contact UPPER KAM GROUP, a dackson Lake Contact UPPER KAM GROUP UPPER KAM GAOUP UPPER KAM GROUP UPPER KAM GROUP UPPER KAM GROUP UPPER KAM GROUP UPPER KAM GAOUP UPPER KAM GROUP UPPER KAM GROUP UPPER KAM GROUP UPPER KAM GROUP UPPER KAM GROUP LOWER BANTING GROUP, $5 \mathrm{~m}$ above base of sill LOWER BANTING GROUP, $5 \mathrm{~m}$ above base of sill LOWER BANTING GROUP, in felsic ash LOWER BANTING GROUP, in folsic ash 
SAMPLE SiO2 $(\%)$ Al2O3 $(\%) \quad F \% O(\%) \quad M g O(\%) \quad \mathrm{CaO}(\%)$

\begin{tabular}{|c|c|c|c|c|c|}
\hline$J L-11-87$ & 57.54 & 12.79 & 9.62 & 7.40 & 8.42 \\
\hline GS-1 & 51.22 & 15.14 & 10.75 & 4.95 & 10.51 \\
\hline GS-3 & 57.50 & 14.54. & 10.55 & 5.45 & 5.80 \\
\hline GS-7 & 55.62 & 16.53 & 12.90 & 5.31 & 2.94 \\
\hline GS-6 & 51.62 & 14.69 & 12.50 & 6.89 & 10.28 \\
\hline GS-6A & 51.67 & 14.55 & 1278 & 6.84 & 10.36 \\
\hline GS-8 & 53.98 & 15.05 & 13.08 & 6.85 & 6.20 \\
\hline$u-12-87$ & 63.65 & 16.41 & 12.12 & 3.62 & 0.44 \\
\hline GS-10 & 51.36 & 14.06 & 13.60 & 5.89 & 11.03 \\
\hline GS-10A & 51.20 & 14.06 & 13.60 & 5.96 & 11.06 \\
\hline GS-11 & 57.88 & 11.19 & 12.96 & 4.29 & 11.17 \\
\hline GS-9 & 53.01 & 14.28 & 13.22 & 7.67 & 7.59 \\
\hline GS-9A & 52.32 & 14.10 & 13.18 & 7.07 & 7.49 \\
\hline GS-19A & 54.33 & 16.61 & 10.73 & 4.72 & 8.79 \\
\hline GS-19 & 53.89 & 16.62 & 10.80 & 4.58 & 8.81 \\
\hline$J L-13-87$ & 47.62 & 16.49 & 13.27 & 6.36 & 12.28 \\
\hline$J L-15-87$ & 50.79 & 17.59 & 15.53 & 9.21 & 3.40 \\
\hline$J L-14-87$ & 50.24 & 21.47 & 15.75 & 8.11 & 0.27 \\
\hline$Y-37$ & 51.57 & 15.77 & 14.01 & 8.92 & 4.08 \\
\hline$Y-38$ & 48.76 & 12.42 & 17.15 & 5.77 & 9.16 \\
\hline$Y-39$ & 49.94 & 14.64 & 13.89 & 705 & 9.95 \\
\hline$Y-40$ & 50.96 & 11.95 & 17.28 & 5.04 & 7.63 \\
\hline$Y-41$ & 50.87 & 15.40 & 14.65 & 6.83 & 7.40 \\
\hline$Y-42$ & 50.96 & 12.05 & 17.35 & 6.12 & 7.61 \\
\hline$Y-43$ & 50.81 & 12.20 & 15.98 & 6.47 & 8.10 \\
\hline$Y-43$ & 49.87 & 14.46 & 16.68 & 5.66 & 5.93 \\
\hline$Y-45$ & 50.29 & 12.04 & 15.97 & 6.52 & 8.66 \\
\hline$Y-47$ & 48.56 & 12.45 & 18.80 & 6.32 & 7.62 \\
\hline$Y-49$ & 49.75 & 14.32 & 16.82 & 5.62 & 5.91 \\
\hline$Y-49 A$ & 50.68 & 12.13 & 15.99 & 6.48 & 8.11 \\
\hline$B A-2-88$ & 50.38 & 14.38 & 12.39 & 7.38 & 10.14 \\
\hline$B A-2 a-88$ & 50.43 & 14.26 & 12.32 & 7.54 & 10.21 \\
\hline$J L-3-88$ & 68.12 & 16.4 & 9.12 & 1.64 & 0.11 \\
\hline $8 A-3-88$ & 41.79 & 26.52 & 11.31 & 3.05 & 2.91 \\
\hline
\end{tabular}


SAMPLE Na2O (\%) K2O (\%) TiO2(\%) P2O5 (\%) MnO (\%)

\begin{tabular}{|c|c|c|c|c|c|}
\hline$J L-11-87$ & 3.25 & 0.06 & 0.66 & 0.05 & 0.21 \\
\hline GS-1 & 5.10 & 0.49 & 1.51 & 0.04 & 0.28 \\
\hline GS-3 & 4.03 & 0.32 & 1.43 & 0.09 & 0.29 \\
\hline GS-7 & 4.69 & 0.14 & 1.57 & 0.10 & 0.20 \\
\hline GS-6 & 2.44 & 0.10 & 1.27 & 0.00 & 0.21 \\
\hline GS-6A & 2.17 & 0.11 & 1.31 & 0.02 & 0.21 \\
\hline GS-8 & 2.81 & 0.35 & 1.40 & 0.08 & 0.21 \\
\hline$J L-12-87$ & 0.63 & 1.24 & 1.66 & 0.15 & 0.08 \\
\hline GS-10 & 2.12 & 0.20 & 1.50 & 0.01 & 0.22 \\
\hline GS-10A & 2.18 & 0.20 & 1.51 & 0.00 & 0.22 \\
\hline GS-11 & 0.71 & 0.05 & 1.57 & 0.01 & 0.16 \\
\hline GS-9 & 2.48 & 0.19 & 1.34 & 0.02 & 0.20 \\
\hline GS-9A & 4.02 & 0.25 & 1.32 & 0.05 & 0.20 \\
\hline GS-19A & 3.05 & 0.38 & 1.19 & 0.00 & 0.20 \\
\hline GS-19 & 3.48 & 0.42 & 1.19 & 0.00 & 0.20 \\
\hline$J-13-87$ & 1.51 & 0.77 & 1.35 & 0.10 & 0.24 \\
\hline$J L-15-87$ & 1.75 & 0.16 & 1.33 & 0.11 & 0.13 \\
\hline$J L-14-87$ & 0.21 & 2.10 & 1.62 & 0.13 & 0.10 \\
\hline$Y-37$ & 3.79 & 0.40 & 1.20 & 0.08 & 0.18 \\
\hline$Y-38$ & 0.95 & 0.08 & 4.27 & 1.22 & 0.22 \\
\hline$Y-39$ & 2.91 & 0.14 & 1.26 & 0.00 & 0.22 \\
\hline$Y-40$ & 0.33 & 0.04 & 4.43 & 1.13 & 0.21 \\
\hline$Y-41$ & 3.31 & 0.10 & 1.23 & 0.00 & 0.21 \\
\hline$Y-42$ & 0.06 & 0.04 & 4.43 & 1.18 & 0.21 \\
\hline$Y-43$ & 0.30 & 0.04 & 4.65 & 1.24 & 0.20 \\
\hline$Y-43$ & 1.42 & 0.03 & 4.46 & 1.28 & 0.21 \\
\hline$Y-45$ & 0.70 & 0.05 & 4.34 & 1.21 & 0.23 \\
\hline$Y-47$ & 0.00 & 0.03 & 4.73 & 1.30 & 0.20 \\
\hline$Y-49$ & 1.56 & 0.04 & 4.46 & 1.33 & 0.21 \\
\hline$Y-49 A$ & 0.32 & 0.04 & 4.68 & 1.35 & 0.20 \\
\hline BA-2-88 & 2.45 & 1.25 & 1.26 & 0.11 & 0.24 \\
\hline BA-2a-8B & 2.38 & 1.24 & 1.30 & 0.10 & 0.24 \\
\hline$J L=3-88$ & 0.34 & 2.45 & 1.57 & 0.06 & 0.15 \\
\hline BA-3-88 & 0.66 & 3.78 & 7.82 & 2.08 & 0.08 \\
\hline
\end{tabular}


SAMPLE Ba (ppm) $\operatorname{Cr}(\mathrm{ppm}) \operatorname{Zr}(\mathrm{ppm}) \operatorname{Sr}(\mathrm{ppm}) \quad \mathrm{Rb}(\mathrm{ppm})$

\begin{tabular}{|c|c|c|c|c|c|}
\hline$J-11-87$ & 95.00 & 280.00 & 31.00 & 86.00 & 0.00 \\
\hline GS-1 & 35.00 & 123.00 & 90.00 & $\mathbf{5 9 . 0 0}$ & 0.00 \\
\hline GS-3 & 41.00 & 131.00 & $\mathbf{9 5 . 0 0}$ & 40.00 & 0.00 \\
\hline GS-7 & 54.00 & 157.00 & $\mathbf{9 8 . 0 0}$ & 36.00 & 0.00 \\
\hline GS-6 & 41.00 & 128.00 & 70.00 & 118.00 & 0.00 \\
\hline GS-6A & 63.00 & 158.00 & 78.00 & 143.00 & 0.00 \\
\hline GS-8 & 31.00 & 163.00 & 87.00 & 49.00 & 0.00 \\
\hline$J \mathrm{~L}-12-87$ & $15 \% .00$ & 140.00 & 86.00 & 83.00 & 47.00 \\
\hline GS-10 & 83.00 & 140.00 & 91.00 & 267.00 & 0.00 \\
\hline GS-10A & 100.00 & 142.00 & $\mathbf{9 4 . 0 0}$ & 265.00 & 0.00 \\
\hline GS-11 & 16.00 & 78.00 & 127.00 & 525.00 & 0.00 \\
\hline GS-9 & 106.00 & 159.00 & 85.00 & 143.00 & 0.00 \\
\hline GS-9A & 97.00 & 155.00 & 8200 & 147.00 & 0.00 \\
\hline GS-19A & 61.00 & 241.00 & 70.00 & 104.00 & 0.00 \\
\hline GS-19 & 72.00 & 233.00 & 69.00 & 106.00 & 0.00 \\
\hline JL-13-87 & 103.00 & 220.00 & 59.00 & 98.00 & 0.00 \\
\hline$J L-15-87$ & 62.00 & 240.00 & 60.00 & 38.00 & 0.00 \\
\hline$J L-14-87$ & 645.00 & 290.00 & 75.00 & 49.00 & 45.00 \\
\hline Y-37 & 57.00 & 176.00 & 57.00 & 50.00 & 0.00 \\
\hline$Y-38$ & 0.00 & 86.00 & 310.00 & 80.00 & 0.00 \\
\hline Y-39 & 29.00 & 153.00 & 56.00 & 85.00 & 0.00 \\
\hline$Y-40$ & 0.00 & 113.00 & 294.00 & 81.00 & 0.00 \\
\hline$Y-41$ & 43.00 & 149.00 & 39.00 & 93.00 & 0.00 \\
\hline$Y-42$ & 0.00 & 117.00 & 299.00 & 81.00 & 0.00 \\
\hline$Y-43$ & 0.00 & 90.00 & 326.00 & 98.00 & 0.00 \\
\hline$Y-43$ & 0.00 & 103.00 & 318.00 & 101.00 & 0.00 \\
\hline$Y-45$ & 0.00 & 87.00 & 314.00 & $\$ 0.00$ & 0.00 \\
\hline$Y-47$ & 0.00 & 67.00 & 325.00 & 115.00 & 0.00 \\
\hline$Y-49$ & 0.00 & 108.00 & 317.00 & $\mathbf{9 9 . 0 0}$ & 0.00 \\
\hline$Y-49 A$ & 0.00 & 106.00 & 324.00 & 97.00 & 0.00 \\
\hline 8A-2-86 & 51.00 & 191.00 & 58.00 & 87.00 & 0.00 \\
\hline BA-2a-88 & 55.00 & 189.00 & 57.00 & 91.00 & 0.00 \\
\hline JL-3-88 & 219.00 & 139.00 & 50.00 & 16.00 & 61.00 \\
\hline $8 n-3-88$ & 117.00 & 129.00 & 594.00 & 71.00 & 100.00 \\
\hline
\end{tabular}


SAMPLE Y (ppm) Nb (ppm) Zn (ppm) Ni (ppm) V (ppm)

\begin{tabular}{|c|c|c|c|c|c|}
\hline $\mathrm{JL}-11-87$ & 0.00 & 0.00 & 86.00 & 100.00 & 230.00 \\
\hline GS-1 & 29.00 & 4.00 & 85.00 & 61.00 & 300.00 \\
\hline GS-3 & 29.00 & 5.00 & 125.00 & 57.00 & 284.00 \\
\hline GS-7 & 26.00 & 0.00 & 117.00 & 63.00 & 381.00 \\
\hline GS-6 & 21.00 & 3.00 & 66.00 & 64.00 & 285.00 \\
\hline GS-6A & 26.00 & 5.00 & 98.00 & 84.00 & 316.00 \\
\hline GS-8 & 28.00 & 2.00 & 116.00 & 51.00 & 337.00 \\
\hline$J L-12-87$ & 0.00 & 0.00 & 130.00 & 140.00 & 340.00 \\
\hline GS-10 & 31.00 & 5.00 & 65.00 & 47.00 & 34.00 \\
\hline GS-10A & 29.00 & 3.00 & 86.00 & 42.00 & 357.00 \\
\hline GS-11 & 37.00 & 3.00 & 74.00 & 25.00 & 366.00 \\
\hline GS-9 & 29.00 & 3.00 & 108.00 & 48.00 & 346.00 \\
\hline GS-9A & 28.00 & 3.00 & 94.00 & 57.00 & 339.00 \\
\hline GS-19A & 25.00 & 2.00 & 47.00 & 102.00 & 316.00 \\
\hline GS-19 & 26.00 & 3.00 & 78.00 & 112.00 & 328.00 \\
\hline JL-13-87 & 0.00 & 0.00 & 120.00 & 140.00 & 290.00 \\
\hline$J L-15-87$ & 0.00 & 0.00 & 120.00 & 150.00 & 310.00 \\
\hline$J L-14-87$ & 21.00 & 0.00 & 150.00 & 170.00 & 360.00 \\
\hline Y-37 & 24.00 & 0.00 & -.131 .00 & 104.00 & 326.00 \\
\hline$Y-38$ & 60.00 & 19.00 & 133.00 & 50.00 & 233.00 \\
\hline$Y-39$ & 22.00 & 2.00 & 104.00 & 103.00 & 290.00 \\
\hline$Y-40$ & 58.00 & 21.00 & 147.00 & 57.00 & 235.00 \\
\hline$Y-41$ & 23.00 & 0.00 & 112.00 & 113.00 & 302.00 \\
\hline$Y-42$ & 59.00 & 22.00 & 122.00 & 81.00 & 251.00 \\
\hline$Y-43$ & 66.00 & 20.00 & 125.00 & 58.00 & 283.00 \\
\hline$Y-43$ & 66.00 & 18.00 & 187.00 & 59.00 & 275.00 \\
\hline$Y-45$ & 64.00 & 21.00 & 117.00 & 41.00 & 234.00 \\
\hline$Y-47$ & 64.00 & 21.00 & 131.00 & 45.00 & 220.00 \\
\hline$Y-49$ & 64.00 & 21.00 & 202.00 & 69.00 & 275.00 \\
\hline$Y-49 A$ & 65.00 & 20.00 & 139.00 & 81.00 & 250.00 \\
\hline BA-2-88 & 26.00 & 4.00 & 105.00 & 50.00 & 292.00 \\
\hline BA-2a-8B & 24.00 & 6.00 & 86.00 & 48.00 & 303.00 \\
\hline$J-3-88$ & 26.00 & 0.00 & 168.00 & 72.00 & 292.00 \\
\hline AA-3-89 & 172.00 & 45.00 & 154,00 & 78.00 & 414.00 \\
\hline
\end{tabular}




\section{SAMPLE DESCRIPTION LOCATION}

G8-5

FD-1-88

FD-1-88

FD-1-88

UL-10-87

$J L-6-87$

$J L-6-88$

BA-1-88

$J L-5-87$

JL-5-88

$\mathrm{JL}-4-88$

$\mathfrak{J}-2-88$

$\mathfrak{J l}-2-87$

$\mathfrak{d L}-3-87$

JL-4-87

JL-1B-88

$J-1 A-88$

JL-16-87

$J L-1-87$

JL-8-87

$\mathrm{JL}-7-87$

JL-9-87

SILPIL

FOLPIL
PHYODACTE BOULDER

FELSIC DYKE

FELSIC DYKE

FELSIC DVKE

FELSIC OYKE

FELSIC DYKE

KAMBBANTING ASH

FELSIC ASH

FELSIC ASH

SANDSTONE

SANDSTONE

SANDSTONE

MAFIC CONGLOMERATE

MAFIC CONGLOMERATE

MAFIC CONGLOMERATE

MAFIC CONGLOMERATE

FELSIC CONGLOMERATE

GRANITE CLAST

QUARTZ BOULDER

FOLIATED PILLOW BRECCTA FOLIATED MAFIC VOLCANIC SLIGHTIY FOLIATED PILLO SILICIFIED PILLOW FOLLATED PILLOW
BODE MEMBER

YELLOREX FLOWS, naar base of section

YELOREX FLOWS, near base of section

YEULOAEX FLOWS, near base of section

UPPER KNM GROUP, $40 \mathrm{~m}$ below Jackson Lake Contact UPPER KMM GROUP, $3 \mathrm{~m}$ betow Jackson Lake Contact

UPPER KAWBANTING GROUP, at Jackson Lake Contact LOWER BANTING GROUP, at top of ash bed

UPPER KAM/BANTING GROUP, at Jackson Lake Contact UPPER KAM GROUP, Sillsediment Complex UPPER KAM GROUP, Sillsediment Complex JACKSON LAKE FOPM., below Banting Fault JACKSON LAKE FORM., $7 \mathrm{~m}$ above the contact JACKSON LAKE FORM., $15 \mathrm{~m}$ above the contact JACKSON LAKE FORM., just above contact JACKSON LAKE FORM., just above contect JACKSON LAKE FOAM., Just above contact JACKSON LAKE CONGLOMERATE JACKSON LAKE CONGLOMERATE

UPPER KAM GROUP, $20 \mathrm{~m}$ below Jacksoñ Lake Contact UPPER KAM GROUP, $15 \mathrm{~m}$ below Jackson Lake Contact UPPER KAM GROUP, $12 \mathrm{~m}$ below Jackson Lake Contact UPPER KAM GROUP, $10 \mathrm{~m}$ below Jackson Lake Contact UPPER KNM GROUP, $8 \mathrm{~m}$ k Jlow Jackson Lake Contact 
SAMPLE SiO2 (\%) Al2O3(\%) FeO (\%) MgO(\%) CaO(\%)

\begin{tabular}{|c|c|c|c|c|c|}
\hline GS-5 & 76.74 & 14.40 & 1.37 & 0.97 & 0.35 \\
\hline FD-1-88 & 75.74 & 14.21 & 1.56 & 1.16 & 1.41 \\
\hline$F D-1-88$ & 75.81 & 14.17 & 1.52 & 1.18 & 1.40 \\
\hline FD-1-89 & 75.73 & 14.19 & 1.56 & 1.27 & 1.41 \\
\hline$\lambda L-10-87$ & 85.60 & 8.34 & 2.13 & 1.19 & 0.84 \\
\hline JL-6-87 & 82.26 & 8.87 & 5.01 & 1.32 & 0.88 \\
\hline JL-6-88 & 75.61 & 14.24 & 5.38 & 1.11 & 0.14 \\
\hline$B A-1-88$ & 81.28 & 12.31 & 3.22 & 0.17 & 0.06 \\
\hline JL-5-87 & 71.91 & 19.27 & 3.17 & 0.71 & 0.16 \\
\hline$J L-5-88$ & 71.29 & 14.54 & 3.95 & 1.22 & 4.06 \\
\hline$\Lambda-4-88$ & 77.86 & 13.44 & 3.81 & 0.73 & 0.14 \\
\hline$J-2-88$ & 76.14 & 10.39 & 4.59 & 3.03 & 3.17 \\
\hline$J L-2-87$ & 56.58 & 17.49 & 10.42 & 6.59 & 4.91 \\
\hline$\mu-3-87$ & 58.33 & 15.30 & 12.08 & 7.90 & 3.63 \\
\hline$J-4-87$ & 45.46 & 25.48 & 18.85 & 5.49 & 0.49 \\
\hline$J L-18-88$ & 71.48 & 15.05 & 7.03 & 2.22 & 0.69 \\
\hline$J-1 A-88$ & 78.89 & 11.68 & 6.77 & 0.64 & 0.28 \\
\hline$J L-16-87$ & 70.73 & 13.19 & 2.58 & 1.15 & 6.06 \\
\hline JL-1-87 & 95.37 & 1.53 & 0.28 & 0.98 & 1.78 \\
\hline$J L-8-87$ & 63.52 & 17.32 & 11.62 & 3.44 & 0.43 \\
\hline $\mathfrak{J}-7-87$ & 80.79 & 11.51 & 3.79 & 0.94 & 0.19 \\
\hline$J l-9-87$ & 68.33 & 17.32 & 7.56 & 1.96 & 0.35 \\
\hline SILPIL & 63.78 & 18.88 & 12.78 & 1.28 & 0.38 \\
\hline FOLPIL & 50.02 & 20.05 & 13.53 & 6.66 & 5.31 \\
\hline
\end{tabular}


SAMPLE Na2O (\%) K2O (\%) TiO2 (\%) P2O5 (\%) MnO (\%)

$\begin{array}{llllll}\text { GS-5 } & 1.44 & 4.20 & 0.40 & 0.08 & 0.05 \\ \text { FD-1-88 } & 0.11 & 4.92 & 0.79 & 0.07 & 0.03 \\ \text { FD-1-88 } & 0.14 & 4.92 & 0.78 & 0.06 & 0.03 \\ \text { FD-1-88 } & 0.02 & 4.91 & 0.80 & 0.07 & 0.03 \\ \text { JL-10-87 } & 0.62 & 1.13 & 0.09 & 0.00 & 0.04 \\ \text { JL-6-87 } & 0.31 & 1.06 & 0.09 & 0.03 & 0.18 \\ \text { JL-6-88 } & 0.68 & 2.22 & 0.41 & 0.09 & 0.12 \\ \text { BA-1-88 } & 0.11 & 2.70 & 0.11 & 0.02 & 0.02 \\ \text { JL-5-87 } & 1.24 & 3.31 & 0.20 & 0.00 & 0.03 \\ \text { JL-5-88 } & 0.99 & 3.43 & 0.39 & 0.05 & 0.07 \\ \text { JL-4-88 } & 0.96 & 2.56 & 0.37 & 0.08 & 0.05 \\ \text { JL-2-88 } & 0.81 & 1.21 & 0.39 & 0.14 & 0.14 \\ \text { JL-2-87 } & 1.11 & 0.95 & 1.28 & 0.50 & 0.17 \\ \text { JL-3-87 } & 0.22 & 1.29 & 1.05 & 0.10 & 0.10 \\ \text { JL-4-87 } & 0.97 & 1.88 & 1.09 & 0.05 & 0.24 \\ \text { JL-18-88 } & 1.20 & 1.43 & 0.71 & 0.09 & 0.09 \\ \text { JL-1A-88 } & 0.42 & 0.52 & 0.49 & 0.15 & 0.15 \\ \text { JL-16-87 } & 4.89 & 0.87 & 0.32 & 0.07 & 0.13 \\ \text { JL-1-87 } & 0.00 & 0.00 & 0.02 & 0.00 & 0.04 \\ \text { JL-8-87 } & 0.63 & 1.51 & 1.29 & 0.12 & 0.12 \\ \text { JL-7-87 } & 0.62 & 1.73 & 0.34 & 0.06 & 0.04 \\ \text { JL-9-87 } & 0.93 & 2.08 & 1.28 & 0.11 & 0.07 \\ \text { SLLIL } & 0.64 & 0.34 & 1.36 & 0.24 & 0.32 \\ \text { FOLPIL } & 1.69 & 0.83 & 1.47 & 0.15 & 0.29\end{array}$


SAMPLE Ba (ppm) $\operatorname{Cr}(p p m) \operatorname{Zr}(p p m) \quad \operatorname{Sr}(p p m) \quad R b(p p m)$

\begin{tabular}{|c|c|c|c|c|c|}
\hline GS-5 & 432.00 & 47.00 & 111.00 & 17.00 & 125.00 \\
\hline FD-1-88 & 1222.00 & 143.00 & 50.00 & 3.00 & 173.00 \\
\hline FD-1-88 & 1253.00 & 134.00 & 48.00 & 2.00 & 170.00 \\
\hline FD-1-88 & 1243.00 & 139.00 & 49.00 & 3.00 & 173.00 \\
\hline$d L-10-87$ & 126.00 & 10.00 & 120.00 & 56.00 & 66.00 \\
\hline$\Lambda L-6-87$ & 114.00 & 16.00 & 117.00 & 29.00 & 40.00 \\
\hline$J L-6-88$ & 267.00 & 31.00 & 104.00 & 38.00 & 60.00 \\
\hline BA-1-88 & 275.00 & 89.00 & 204.00 & 16.00 & 72.00 \\
\hline$J L-5-87$ & 363.00 & 9.00 & 321.00 & 111.00 & 77.00 \\
\hline$J L-5-88$ & 521.00 & 26.00 & 105.00 & 31.00 & 80.00 \\
\hline$J L-4-88$ & 266.00 & 99.00 & 89.00 & 29.00 & 66.00 \\
\hline JL-2-88 & 375.00 & 190.00 & 107.00 & 100.00 & 36.00 \\
\hline$J L-2-87$ & 166.00 & 10.00 & 141.00 & 104.00 & 28.00 \\
\hline$J L-3-87$ & 603.00 & 100.00 & 63.00 & 72.00 & 59.00 \\
\hline JL-4-87 & 232.00 & 200.00 & 70.00 & 46.00 & 78.00 \\
\hline$J L-18-88$ & 212.00 & 83.00 & 91.00 & 74.00 & 38.00 \\
\hline$J L-1 A-88$ & 150.00 & 250.00 & 168.00 & 37.00 & 11.00 \\
\hline JL-16-87 & 630.00 & 15.00 & 118.00 & 258.00 & 30.00 \\
\hline JL-1-87 & 63.00 & 11.00 & $Q 00$ & 32.00 & 0.00 \\
\hline$J L-8-87$ & 197.00 & 240.00 & 69.00 & 70.00 & 67.00 \\
\hline$J L-7-87$ & 185.00 & 15.00 & 86.00 & 53.00 & 38.00 \\
\hline JL-9-87 & 395.00 & 230.00 & 65.00 & 60.00 & 49.00 \\
\hline SILPIL & 68.00 & 275.00 & 77.00 & 35.00 & 3.00 \\
\hline FOLPIL & 176.00 & 275.00 & 76.00 & 125.00 & 25.00 \\
\hline
\end{tabular}


SAMPLE $Y(p p m) \quad N b(p p m) Z n(p p m) ~ N i(p p m) \quad V(p p m)$

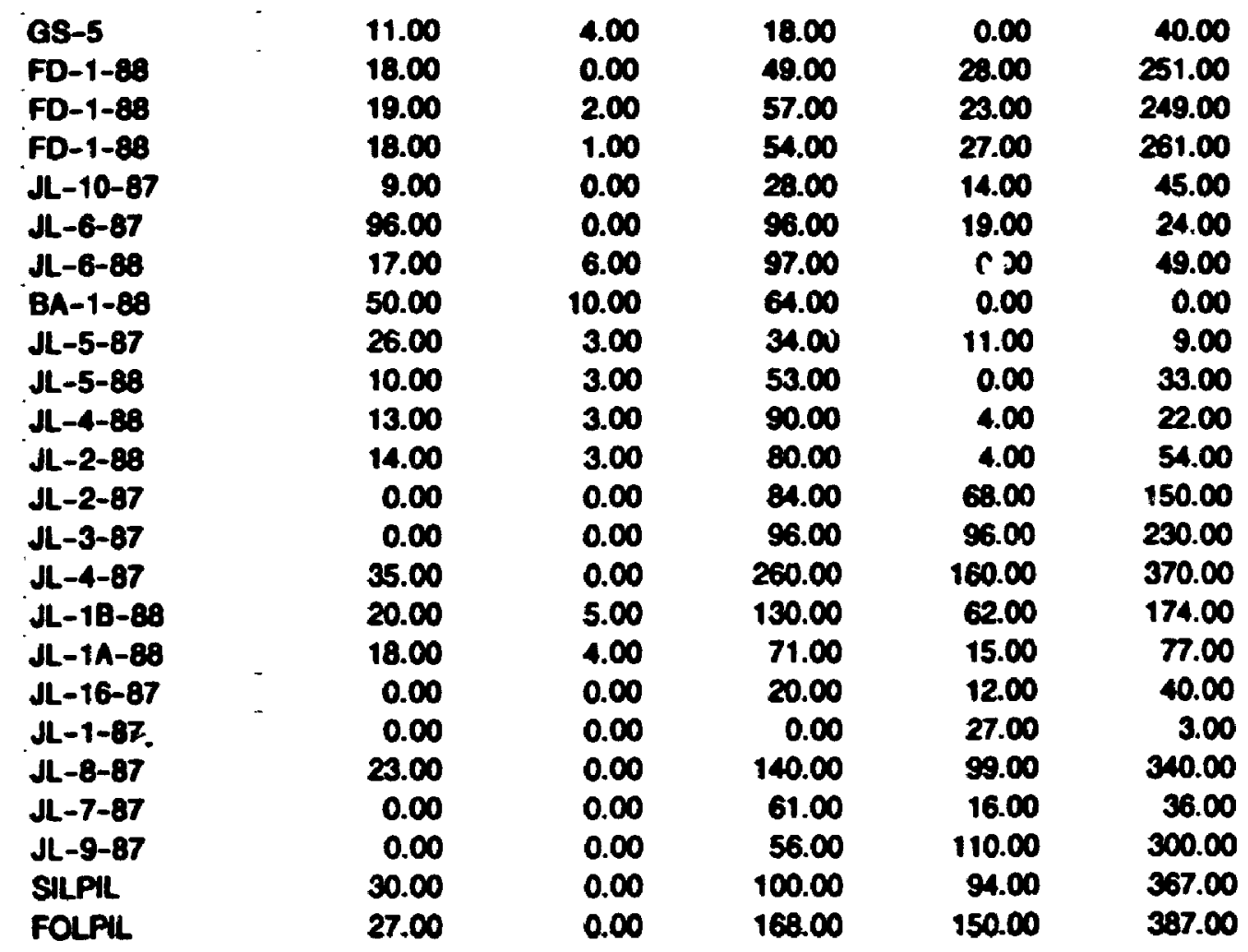



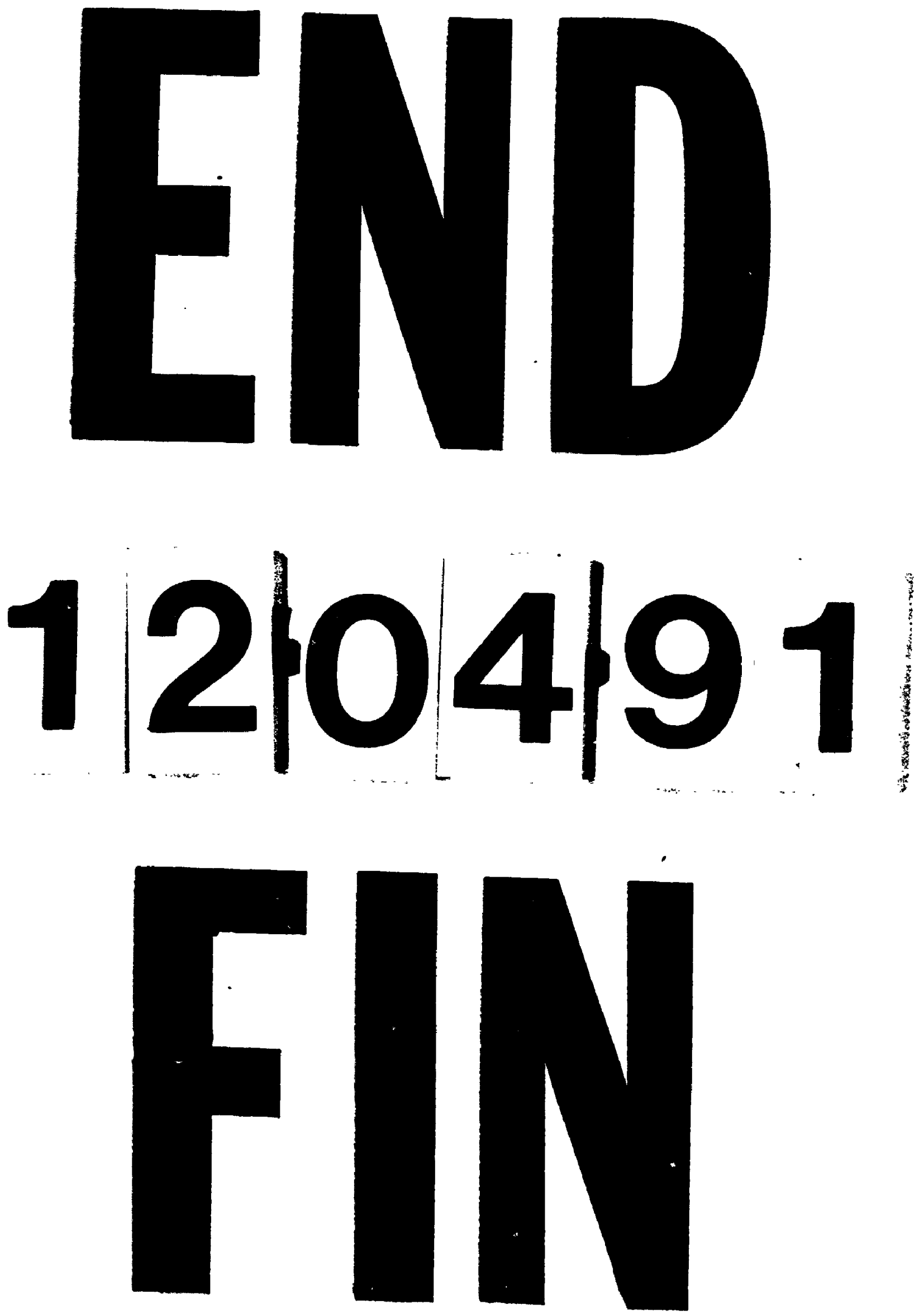